UNIVERSIDADE DE BRASÍLIA - UnB

INSTITUTO DE GEOCIÊNCIAS - IG

CURSO DE PÓS-GRADUAÇÃO EM GEOLOGIA

\title{
Rochas albitizadas e albititos relacionados a mineralizações de estanho da Província Estanífera de Goiás: caracterização petrológica e gênese
}

DISSERTAÇÃO DE MESTRADO Nº333

Ana Rita Félix Sirqueira 


\title{
Rochas albitizadas e albititos relacionados a mineralizações de estanho da Província Estanífera de Goiás: caracterização petrológica e gênese
}

\author{
Ana Rita Félix Sirqueira
}

Orientadora:

Prof. Dra. Márcia Abrahão Moura

Co-Orientador:

Prof. Dr. Nilson Francisquini Botelho

Banca Examinadora:

Prof. Dra. Márcia Abrahão Moura (UnB)

Prof. Dr. Valmir da Silva Souza (UnB)

Dr. Hilton Tulio Costi (Museu Paraense Emílio Goeldi) 
Rochas albitizadas e albititos relacionados a mineralizações de estanho da Província Estanífera de Goiás: caracterização petrológica e gênese.

"Talvez não tenha conseguido fazer o melhor, mas lutei para que o melhor fosse feito.

Não sou o que deveria ser, mas Graças a Deus, não sou o que era antes".

Marthin Luther King 


\section{AGRADECIMENTOS}

Deixo aqui os meus sinceros agradecimentos a pessoas, instituições e empresa, sem as quais não poderia ser possível a realização deste trabalho.

Em primeiro lugar, agradeço a Deus por ter me proporcionado essa oportunidade única na minha vida, pois sem Ele não poderia ter chegado até aqui e enfrentado os mais difíceis obstáculos.

À minha família por ter me apoiado sempre nas minhas escolhas, em especial a minha querida mãe.

A minha tia Martinha pelo carinho e pela hospedagem em sua casa e ao meu primo Márcio Anderson.

À Universidade de Brasília (UnB).

Ao CNPq pela concessão de bolsa de Mestrado.

A minha Orientadora Márcia Abrahão Moura pela valiosa orientação e carinho durante toda a etapa de mestrado.

Ao meu Co-orientador Nilson Francisquini Botelho pelas dicas e sugestões, e pela disposição em sempre me ajudar.

A Empresa de Desenvolvimento em Mineração (EDEM) pela autorização para o desenvolvimento da presente pesquisa e fornecimento de informações e dos furos de sondagem dos garimpos estudados, em particular ao Geólogo Gustavo Guerra.

Ao Professor Valmir Souza pela ajuda e pelo fornecimento de dados para o complemento dessa dissertação.

Aos professores do curso de pós-graduação em geologia em especial aos Professores Mássimo Matteini e Natália Hauser, pelos ensinamentos e apoio.

Aos amigos Leornado Santacruz, Hudson Queiroz, Carlos Collado, Ítalo Lopes e Ricardo Lívio que de alguma forma me ajudaram na realização deste trabalho, com suas dicas e ajuda na preparação de amostras.

Aos amigos Luís Bonfim, Luciane Katiuscia, Vitor Nascimento, Alan Constantino, Erich Adam, Solon Mendes, Isabela Moreno, Samille Souza, Thiago Câmara, Diego Timoteo e Igor Vasconcelos pelos momentos divertidos e pela amizade.

\section{Muito Obrigada a todos.}




\section{SUMÁRIO}

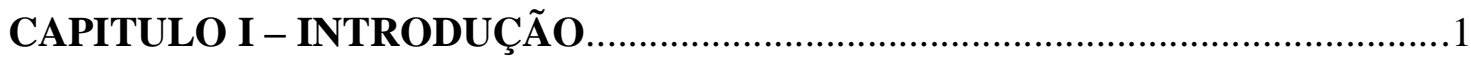

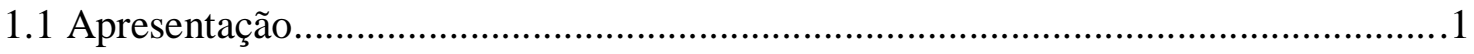

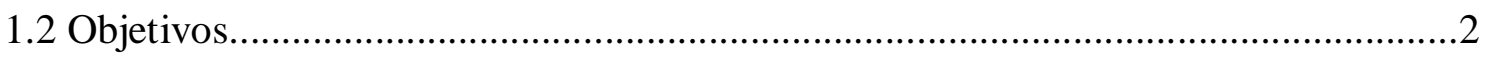

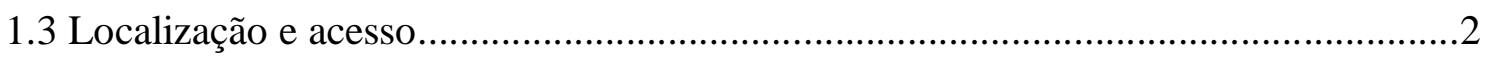

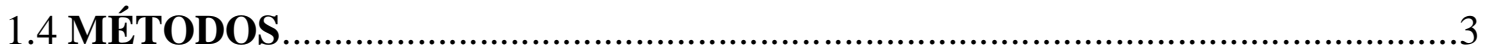

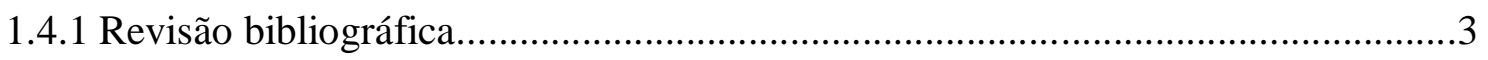

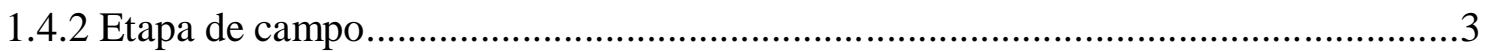

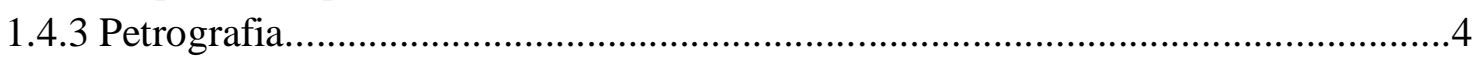

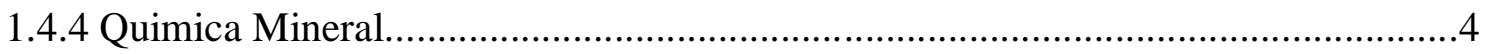

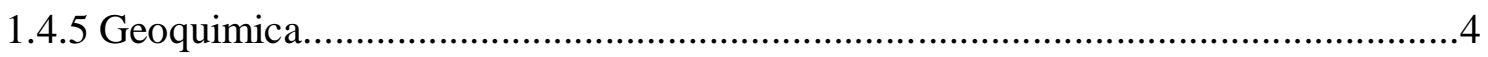

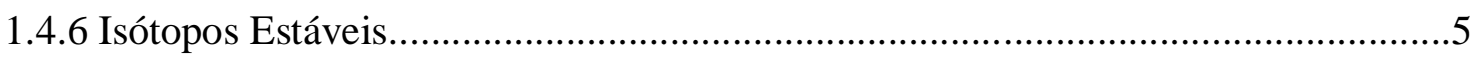

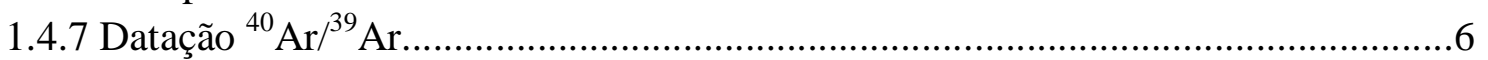

CAPITULO II - GEOLOGIA REGIONAL E LOCAL .......................................... 7

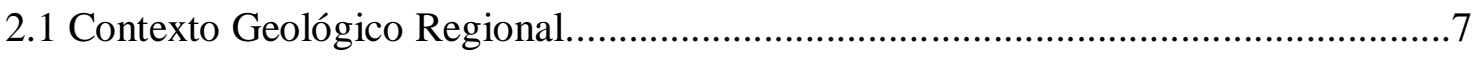

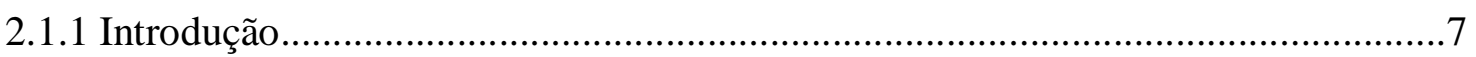

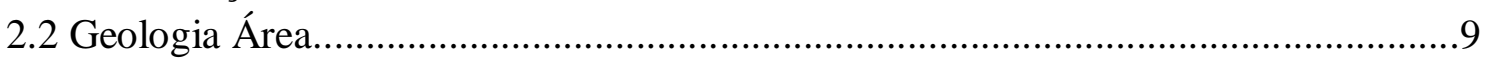

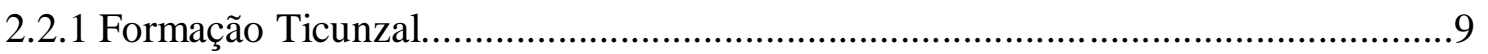

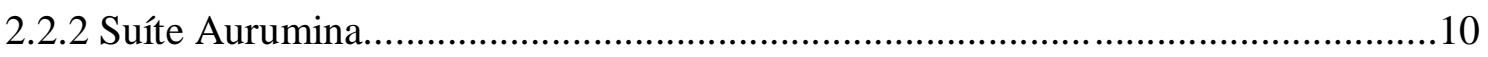

CAPITULO III - ALBITITOS DA PROVÍNCIA ESTANÍFERA DE GOIÁs: PETROLOGIA, GEOQUÍMICA ISOTÓPICA E GÊNESE .................................16

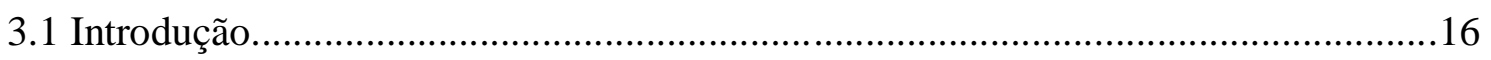

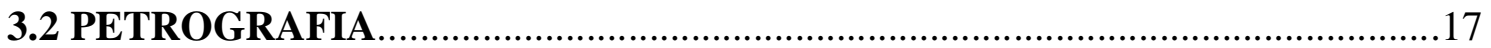

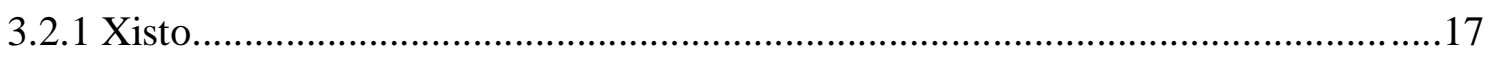

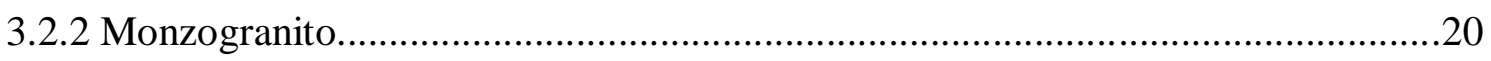

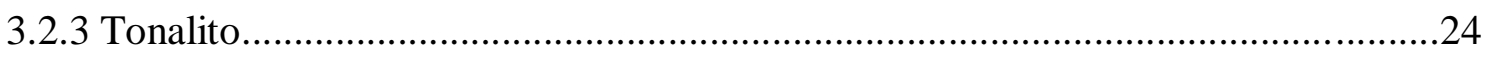

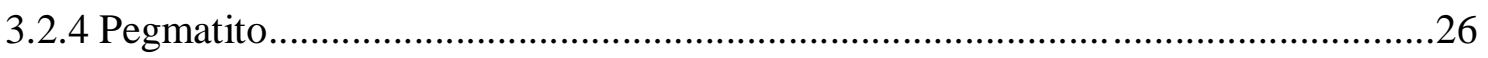

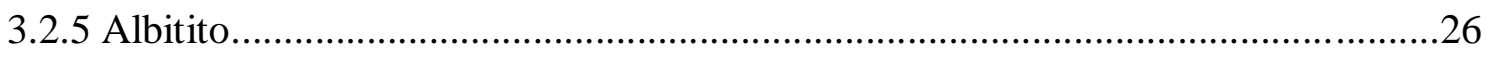

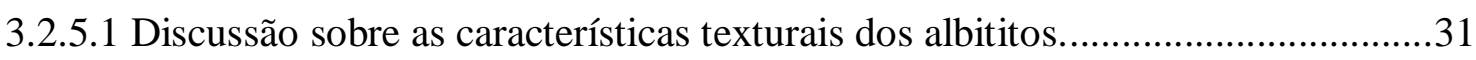

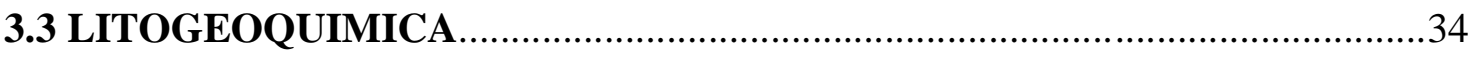

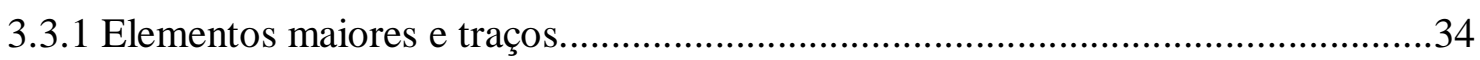

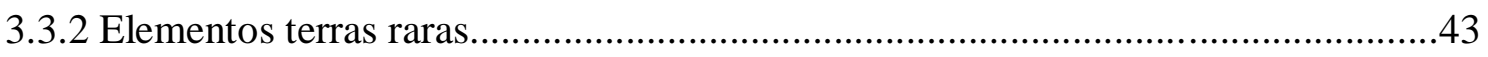

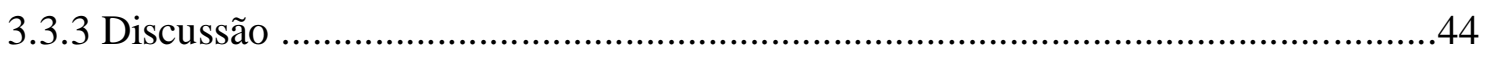

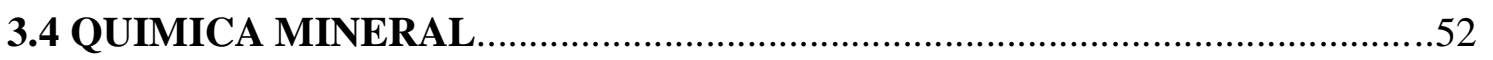

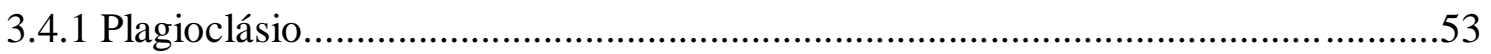

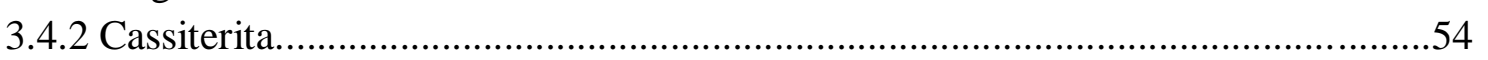

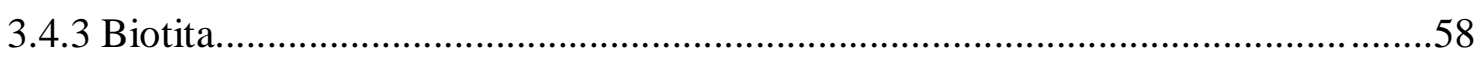

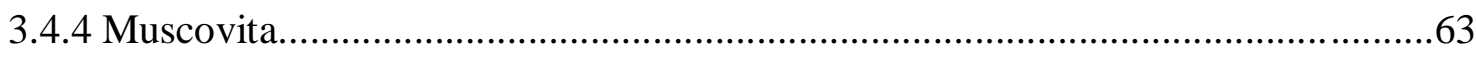

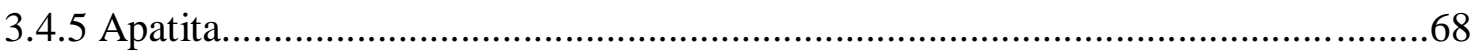

3.5 DISCUSSÃO SOBRE OS DADOS DE LITOGEOQUÍMICA E QUÍMICA MINERAL. 
3.5.1 COMPARAÇÃO ENTRE OS SISTEMAS LCT E NYF DA PROVÍNCIA

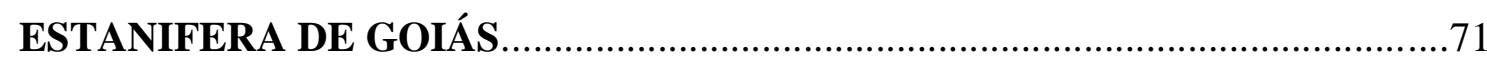

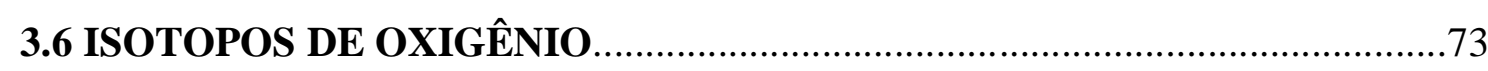

3.6.1Interpretação dos dados de isótopos de oxigênio.................................................76

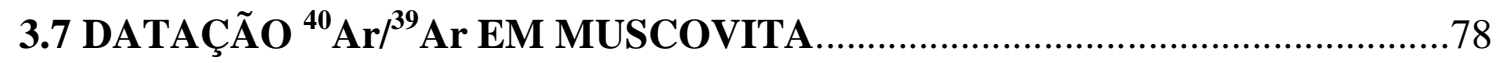

CAPITULO IV - DISCUSSÕES E CONCLUSÕES .............................................82

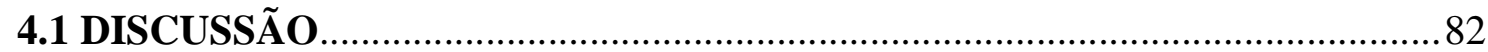

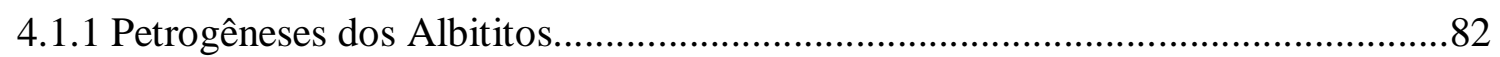

4.1.2 Condições de Cristalização dos Albititos e das Rochas Associadas......................83

4.1.3 Rochas Evoluidas Relacionadas à Mineralização de Estanho.................................87

4.1.4 Comparação dos Albititos e Rochas Associadas Com o Depósito de Estanho da Mina de Pitinga (PEP) e Rochas Peraluminosas da Suíte Aurumina (PEG)...................90

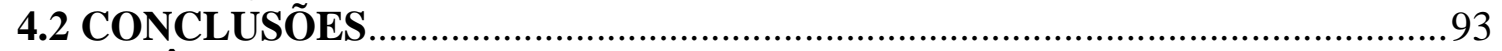

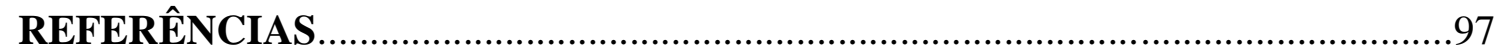

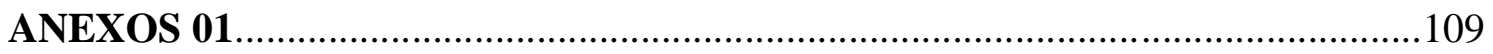

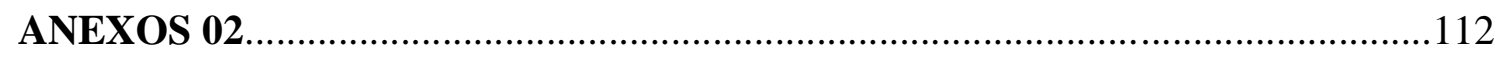

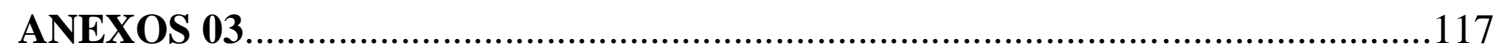

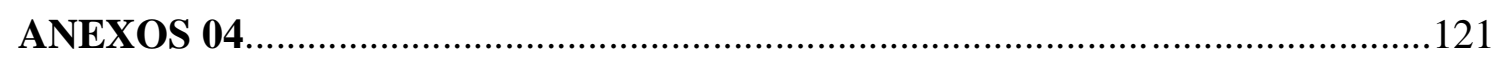

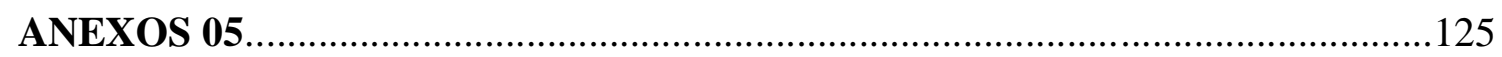




\section{LISTA DE FIGURAS}

Figura 1.1: Mapa de localização da área de estudo.

Figura 2.1: Mapa geológico da Província Estrutural de Tocantins (Marini et al. 1984 e Fuck 1994)

Figura 2.2: Mapa geológico da região nordeste de Goiás, com destaque para a área estudada (Moura et al. 2014).

Figura 2.3: Perfil esquemático dos furos de sondagem do garimpo Pelotas, mostrando a variação litológica de cada furo, com base em análise macroscópica, microscópica e química. As profundidades com apenas um asterisco (*) indicam a localização das amostras com estudo petrográfico; as profundidades com dois asteriscos (**) indicam a localização das amostras com estudo petrográfico e análise química 13

Figura 2.4: Perfil esquemático dos furos de sondagem FPS-6 e FPS-8 do garimpo Pelotas, mostrando detalhe dos principais litotipos descritos. As profundidades com apenas um asterisco (*) indicam a localização das amostras com estudo petrográfico; as profundidades com dois asteriscos (**) indicam a localização das amostras com estudo petrográfico e análise química. 14

Figura 2.5: Mapa geológico da área da região de Porto Real, mostrando a localização dos garimpos Pelotas e Boa Vista (Trabalho Final (UnB) 2005).

Figura 3.1: Diagramas modais Q-A-P e Q-(A+P)-M' (Streckeisen 1976), mostrando a variação composicional dos granitos do garimpo Pelotas..

Figura 3.2: Fotomicrografia das rochas graníticas e dos xistos: (a) Biotita anedral em nicóis paralelos que ocorre na fácies muscovita-biotita monzogranito; (b) Textura mimerquítica, com intercrescimento de quartzo vermicular no plagioclásio, sendo este parcialmente sericitizado na fácies biotita-muscovita tonalito; (c) Quartzo microcristalino, com extinção ondulante com contato tríplice presente na fácies biotitamuscovita tonalito; (d) Cristal de granada, com inclusão de quartzo, presente no muscovita-biotita monzogranito; (e) Aspecto textural do grafita-clorita xisto em nicóis paralelos, com presença de clorita e com destaque para os cristais de grafita com forma ondulada; (f) Textura mimerquitano plagioclásio e muscovita primária na fácies biotitamuscovita monzogranito.

Figura 3.3: Aspectos mineralógicos e texturais dos albititos dos garimpos Boa Vista e Pelotas. a) Aspecto macroscópico dos albititos mostrando contato abrupto com o granito; b) Cristais de quartzo com inclusões de ripas de albita, formando textura snowball; c) Fenocristal euedral de cassiterita; d) Cristal de muscovita magmática com bordas corroídas; e) Contato entre o albitito e o biotita-muscovita monzogranito; (f) Apatita intersticial com inclusão de albita e contatos reentrantes com a muscovita magmática.

Figura 3.4: Aspectos mineralógicos e texturais dos albititos dos garimpos Boa Vista e Pelotas. a) Vênula de quartzo com extinção ondulante e contato serrilhado cortando os cristais de albita; b) Cristais de albita sem orientação preferencial; c) Cristais de muscovita com hábito subedral apresentando borda de reação; d) Cristal de apatita com 
hábito anedral com inclusões de muscovita; e, f) Cristais de cassiterita com hábito euedral e anedral com inclusões de quartzo.

Figura 3.5: Desenho esquemático da textura snowball que ocorre nos albititos; a) "Ripas" de albita concentradas no núcleo do cristal de cassiterita; b) "Ripas" de albita ao longo das bordas do cristal de apatita....

Figura 3.6: Características texturais dos albititos (textura snowball); a, b) Cassiterita com inclusões de ripas de albita no núcleo; c, d) Inclusões de ripas de albita por todo o cristal de apatita e dispostas paralelamente às bordas da apatita, respectivamente; e,f) Alinhamento de ripas de albita configurando textura interpretada como cumulática.

Figura 3.7: Diagrama de Shand (1943), mostrando o caráter peraluminoso dos monzogranitos e tonalitos e o caráter metaluminoso a peraluminoso dos albititos dos garimpos Pelotas e Boa Vista, e o diagrama ISA vs. $\mathrm{SiO}_{2}$, evidenciado o caráter peraluminoso com o aumento da sílica

Figura 3.8: Diagramas de variação de elementos maiores e traços em relação ao $\mathrm{SiO}_{2}$, em comparação com os xistos, monzogranitos, tonalitos e albititos.

Figura 3.9: Diagramas de variação de elementos maiores em relação ao $\mathrm{SiO}_{2}$, como índice de diferenciação, para os monzogranitos e tonalitos e dos albititos dos garimpos Pelotas e Boa Vista.

Figura 3.10: Diagramas de variação de elementos-traço em relação ao $\mathrm{SiO}_{2}$, como índice de diferenciação, para os monzogranitos e tonalitos e dos albititos dos garimpos Pelotas e Boa vista.

Figura 3.11: Relação entre $\mathrm{U}$ e $\mathrm{SiO}_{2}$, mostrando o empobrecimento do $\mathrm{U}$ tanto nos albititos como nos monzogranitos e tonalitos.

Figura 3.12: Comportamento dos ETR normalizados para valores condríticos segundo Nakamura, 1974) a) para os albititos; b) para os xistos, monzogranitos e tonalitos

Figura 3.13: Diagramas binários de óxidos e elementos-traço em relação ao $\mathrm{MgO}$, para as rochas graníticas

Figura 3.14: Amostras de monzogranito e tonalito plotadas nos diagramas discriminantes de ambiente tectônico de Pearce et al. (1984).

Figura 3.15: Comportamento dos elementos-traço normalizados aos granitos de cadeias oceânicas (ORG) dos monzogranitos e tonalitos, segundo Pearce et al. (1984).

Figura 3.16: Diagramas de discriminação geotectônica das rochas magmáticas ácidas sin-colisionais (syn-C), pós-colisionais + sin-subducção $(\mathrm{P})$, anorogênicas não hiperalcalinas (A) e hiperalcalinas $(\mathrm{H})$, propostos por Thiéblemont \& Cabanis (1990)

Figura 3.17: Diagrama proposto por Harris et al. (1986), diferenciando os granitos intraplaca (WP) de arco vulcânico (VA), pós-colisionais (grupo III) e sin-colisionais (grupo II) para os monzogranitos e tonalitos.

Figura 3.18: Diagrama de classificação do plagioclásio analisado, evidenciando o caráter altamente sódico. 
Figura 3.19: Diagrama de correlação atômica das cassiteritas dos garimpos Pelotas e Boa Vista; a) e b) $\mathrm{Ta}+\mathrm{Nb}$ e $\mathrm{Fe}+\mathrm{Mn}$ vs. Sn, mostrando o comportamento desses elementos na estrutura das cassiteritas; c) Diagrama ternário Fe-Ta-Nb, que mostra a variação química nas cassiteritas; d) Diagrama mostrando o comportamento de Sb vs. Sn nas cassiteritas.

Figura 3.20: a) Cassiterita dos albititos do garimpo Boa Vista; b) Cassiterita dos albititos do garimpo Pelotas, com seus respectivos perfis, que mostram a variação da composição de acordo com as diferentes zonas nesses cristais.

Figura 3.21: Diagrama mostrando a relação $\mathrm{Ta}_{2} \mathrm{O}_{5}$ vs. $\mathrm{Nb}_{2} \mathrm{O}_{5}$ nas cassiteritas dos garimpos Boa Vista e Pelotas.

Figura 3.22: Diagrama ( $\mathrm{FeO}+\mathrm{MnO})-(10 * \mathrm{TiO})-\mathrm{MgO}$ de Nachit et al. (2005), mostrando as variações composicionais das biotitas analisadas $(\mathrm{A}=$ campo de biotita magmática primária; $\mathrm{B}=$ campo de biotita magmática reequilibrada; $\mathrm{C}=$ campo de biotita neoformada)

Figura 3.23: Diagrama $\mathrm{Al}^{\mathrm{IV}} v s$. Fe/(Fe+Mg), proposto por Deer et al. (1963)

Figura 3.24: Relações entre $\mathrm{MgO}-\mathrm{Al}_{2} \mathrm{O}_{3}, \mathrm{FeO}_{(\mathrm{t})}-\mathrm{Al}_{2} \mathrm{O}_{3}, \mathrm{MgO}-\mathrm{FeO}_{(\mathrm{t})} \mathrm{e} \mathrm{MgO}-\mathrm{FeO}_{(\mathrm{t})}$ $\mathrm{Al}_{2} \mathrm{O}_{3}$ da biotita dos monzogranitos e tonalitos, no diagrama proposto por AbdelRahman (1994) ( $\mathrm{A}=$ Granitos alcalinos; $\mathrm{C}=\mathrm{Granitos}$ cálcio-alcalinos; $\mathrm{P}=\mathrm{Granitos}$ peraluminosos)......

Figura 3.25: Diagramas de variações composicionais dos diferentes tipos de biotita analisados para avaliar as substituições dos elementos nas ocupações octaédrica e tetraédrica; a) Diagrama ${ }^{\mathrm{R} 2+}$ vs. $\mathrm{R}^{3+}$, mostrando correlação negativa entre os elementos; b) Diagrama $\mathrm{Al}^{\mathrm{IV}} v s$. $\mathrm{Fe}(\mathrm{t})$, mostrando correlação positiva; c) Diagrama $\mathrm{Al}^{\mathrm{VI}} v s . \mathrm{Fe}(\mathrm{t})$, evidenciando a substituição entre esses elementos; d) Diagrama $\mathrm{Si} v s$. Fe(t), com correlação negativa; e) Diagrama Ti vs. Si, mostrando o baixo conteúdo de Ti entre a biotita magmática e a reequilibrada; f) Diagrama $\mathrm{Al}^{\mathrm{IV}}+\mathrm{Fe}+\mathrm{Mg}$ vs. $\mathrm{Al}^{\mathrm{VI}}+\mathrm{Si}$, com correlação negativa

Figura 3.26: Classificação das micas dioctaédricas no diagrama $\mathrm{M}^{2+}-\mathrm{Al}-\mathrm{Si}$, proposto por Monier \& Robert (1986), $\mathrm{M}^{2+}=\mathrm{Fe}^{2+}(\mathrm{t})+\mathrm{Mg}+\mathrm{Mn}$.

Figura 3.27: Diagrama de discriminação geoquímica para a muscovita primária e secundária; a) Diagrama $\mathrm{Ti}$ vs. $\mathrm{Fe} /(\mathrm{Fe}+\mathrm{Mg})$; b) Diagrama $\mathrm{Na}$ vs. $\mathrm{Fe} /(\mathrm{Fe}+\mathrm{Mg})$; c) Diagrama $\mathrm{Mg}$ vs. $\mathrm{Fe} /(\mathrm{Fe}+\mathrm{Mg})$; d) Diagrama $\mathrm{Al}(\mathrm{t})$ vs. $\mathrm{Fe} /(\mathrm{Fe}+\mathrm{Mg})$, segundo Sun et al. (2002); e) Diagrama Fe(t) vs. Fe/(Fe+Mg); f) Diagrama Si vs. Fe/(Fe+Mg), baseado em Sun et al. (2002)...

Figura 3.28: Variação composicional para a muscovita mostrando as substituições dos elementos nos sítios octaédrico e tetraédrico; a), b), c) e d) Diagramas de correlação de cátions dos diferentes tipos de muscovita estudados.

Figura 3.29: a) Composição da apatita, evidenciando o seu alto conteúdo de $\mathrm{F}$ em relação a $\mathrm{Cl}$ e $\mathrm{OH}$; b) Gráfico mostrando a diferença entre os conteúdo de $\mathrm{F}$ e $\mathrm{Cl}$...

Figura 3.30: Proporções atômicas em apatita a) $\mathrm{Fe}+\mathrm{Mn} v s . \mathrm{Ca}+\mathrm{P}$; b) ETR+Si vs. $\mathrm{Ca}+\mathrm{P}$; c) Fe vs. P; d) Ca vs. P, mostrando uma leve correlação negativa e positiva entre esses elementos. 
Figura 3.31: Relação $\mathrm{Ta}_{2} \mathrm{O}_{5} v s$. $\mathrm{Nb}_{2} \mathrm{O}_{5}$ da cassiterita dos albititos em comparação com a cassiterita das rochas das Suítes Aurumina e Intraplaca. .73

Figura 3.32: Valores de $\delta^{18} \mathrm{O}(8,68$ a $9,72 \%)$ calculados para os fluidos em equilíbrio isotópico (linha vermelha) em comparação com os valores comuns dos principais reservatórios (adaptado de Campbell \& Larson 1998).

Figura 3.33: Idades platô ${ }^{40} \mathrm{Ar} /{ }^{39} \mathrm{Ar}$, representando a idade de cristalização da muscovita. 81

Figura 4.1: Gráfico ETR vs. MgO mostrando a diminuição do conteúdo de ETR para as fases mais evoluídas .84

Figura 4.2: Relação entre $\mathrm{Na}_{2} \mathrm{O}, \mathrm{TiO}_{2}, \mathrm{Th}, \mathrm{Zr}$ vs. $\mathrm{MgO}$ revelando a diferenciação magmática das rochas estudadas. .87

Figura 4.3: Diagrama $\mathrm{Sn}, \mathrm{Ta}, \mathrm{Nb}$ vs. $\mathrm{MgO}$ mostrando o enriquecimento desses elementos apenas nos albititos.....

Figura 4.4: Gráfico Th vs. $\mathrm{K}_{2} \mathrm{O} / \mathrm{Na}_{2} \mathrm{O}$ das fácies da Suíte Aurumina em comparação com as rochas estudadas nesse trabalho, com destaque para os altos valores de Th nas fácies $\mathrm{Au} 2$ e Au4. .91 


\section{LISTA DE TABELAS}

Tabela 3.1: Composições modais das rochas estudadas. Abreviações: (p) primários; (s) secundários; (tr) mineral-traço. MBT: Muscovita-biotita tonalito; BMT: Biotitamuscovita tonalito; MBM: Muscovita-biotita monzogranito; BMM: Biotita-muscovita monzogranito; GCBQX: Granada-clorita-biotita-quartzo xisto; GCX: Grafita-clorita xisto. .19

Tabela 3.2: Resultados da análise química de rocha total nas amostras da área de estudo. Abreviações: BMT (biotita-muscovita tonalito); BMM (biotita-muscovita monzogranito); MBM (muscovita-biotita mozogranito)

Tabela 3.3: Diferenças composicionais dos cristais de muscovita da fácies biotitamuscovita tonalito e dos albititos. .63

Tabela 3.4: Composição isotópica dos pares de albita-cassiterita; valores calculados para os intervalos de temperaturas de cristalização; e intervalo de composição isotópica

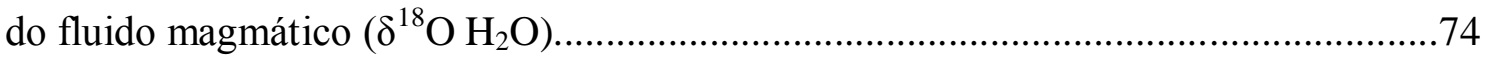
Tabela 3.5: Dados analíticos ${ }^{40} \mathrm{Ar} /{ }^{39} \mathrm{Ar}$ para os albititos do garimpo Boa Vista. .80 


\section{RESUMO}

Os albititos mineralizados em estanho localizados nos garimpos Pelotas e Boa Vista, pertencentes à Província Estanífera de Goiás (PEG), cortam monzogranitos e tonalitos pertencentes à Suíte Aurumina e xistos da Formação Ticunzal. Os albititos são constituídos por albita, quartzo, cassiterita, apatita, K-feldspato e muscovita primária. Texturalmente apresentam alinhamento de "ripas" de albita e textura snowball, interpretados como texturas típicas de albititos de origem magmática. Os tonalitos, monzogranitos e xistos foram divididos em fácies: biotita-muscovita tonalito, muscovita-biotita tonalito, biotita-muscovita monzogranito, muscovita-biotita monzogranito, granada-clorita-biotita-quartzo xisto e grafita-clorita xisto. Os albititos são metaluminosos a peraluminosos, enquanto os monzogranitos e tonalitos são fortemente peraluminosos. Os albititos são enriquecidos em $\mathrm{Na}_{2} \mathrm{O}, \mathrm{Al}_{2} \mathrm{O}_{3}$ e $\mathrm{P}_{2} \mathrm{O}_{5}$, contêm teores moderados de $\mathrm{CaO}$ e são empobrecidos em $\mathrm{K}_{2} \mathrm{O}, \mathrm{TiO}_{2}, \mathrm{Fe}_{2} \mathrm{O}_{3}$ e $\mathrm{MgO}$. Com relação aos elementos-traço, são enriquecidos em $\mathrm{Sn}, \mathrm{Ta}, \mathrm{Rb}, \mathrm{Nb}$ e $\mathrm{Zr}$ e empobrecidos em Sr, Ba e Th. São enriquecidos em elementos terras raras leves (ETRL) em relação aos elementos terras raras pesados (ETRP). As anomalias de Eu são ausentes ou muito discretas, levemente positivas. Os tonalitos e monzogranitos são enriquecidos em $\mathrm{TiO}_{2}, \mathrm{Fe}_{2} \mathrm{O}_{3}, \mathrm{MgO}, \mathrm{CaO}$ e $\mathrm{K}_{2} \mathrm{O}$ e empobrecidos em $\mathrm{Al}_{2} \mathrm{O}_{3}, \mathrm{Na}_{2} \mathrm{O}, \mathrm{P}_{2} \mathrm{O}_{5}, \mathrm{SnO}_{2}$, $\mathrm{TaO}_{2}, \mathrm{Rb}, \mathrm{Nb}$ e $\mathrm{Zr}$. Os padrões de ETRs para os granitos e tonalitos mostram que são enriquecidos em ETRL e empobrecidos em ETRP. As anomalias de Eu para os monzogranitos são muito discretas, podendo ser levemente positivas ou negativas. Os tonalitos apresentam pronunciada anomalia positiva de Eu. Análises em microssonda eletrônica permitiram classificar a biotita do muscovita-biotita tonalito e do muscovitabiotita monzogranito como siderofilita, com razão $\mathrm{Fe} /(\mathrm{Fe}+\mathrm{Mg})$ entre 0,58 a 0,71 a.f.u. e conteúdo de $\mathrm{Al}^{\mathrm{IV}}$ entre 2,1 a 3,3 a.f.u.. Composicionalmente, classifica-se como biotita de granitos peraluminosos. A muscovita dos albititos é mais enriquecida em $\mathrm{Na}_{2} \mathrm{O}$ e $\mathrm{SiO}_{2}$ e empobrecida em $\mathrm{MgO}, \mathrm{Fe}_{2} \mathrm{O}_{3}, \mathrm{Al}_{2} \mathrm{O}_{3}$ e $\mathrm{TiO}_{2}$, e a muscovita da fácies biotitamuscovita tonalito é enriquecida em $\mathrm{MgO}, \mathrm{Fe}_{2} \mathrm{O}_{3}, \mathrm{Al}_{2} \mathrm{O}_{3}$ e $\mathrm{TiO}_{2}$ e empobrecida em $\mathrm{Na}_{2} \mathrm{O}$ e $\mathrm{SiO}_{2}$. Os valores de $\mathrm{TiO}_{2}$ da muscovita secundária é sempre inferior a $0,5 \%$. Entretanto, a muscovita primária possui teores variáveis de $\mathrm{TiO}_{2}$, desde quase nulos a 1\%. A cassiterita é euedral a subedral, maclada, zonada e com forte pleocroísmo, com composições muito puras, com o $\mathrm{Sn}$ substituído principalmente por $\mathrm{Nb}$ e $\mathrm{Ta}$. $\mathrm{O}$ plagioclásio apresenta composição de albita-oligoclásio $\left(\mathrm{Ab}_{77-99} \mathrm{An}_{22-1} \mathrm{Or}_{1}\right)$ nos 
monzogranitos e de albita $\left(\mathrm{Ab}_{90-99} \mathrm{An}_{10-0,6} \mathrm{Or}_{0,4}\right)$ nos tonalitos e albititos. A apatita é classificada como fluorapatita e é interpretada como sendo ígnea. Dados de isótopos de oxigênio em pares de albita e cassiterita mostraram que os albititos foram cristalizados em temperatura que varia de 653 a $1016^{\circ} \mathrm{C}$. As composições isotópicas do fluido calculadas para os albititos, 9,17 a 9,35\% para o albitito do garimpo Pelotas e 8,66 a 9,72\% para o albitito do garimpo Boa Vista, sugerem fluido de origem magmática. Valores de ${ }^{40} \mathrm{Ar} /{ }^{39} \mathrm{Ar}$ em muscovita dos albititos do garimpo Boa Vista resultaram em

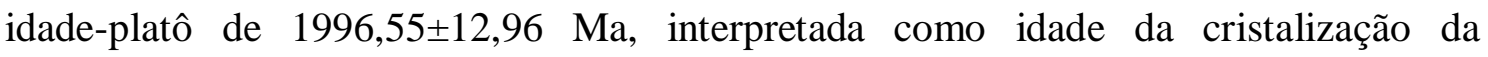
muscovita. Esses dados geocronológicos permitem propor que os albititos da área foram formados durante o Paleoproterozóico, sendo correlacionados às fases tardias do magmatismo da Suíte Aurumina (2,12-2,17 Ga - U-Pb em zircão). Os dados mineralógicos, geoquímicos, de química mineral e isotópicos obtidos permitiram classificar as mineralizações de Sn hospedadas em albititos dos garimpos Pelotas e Boa Vista como magmáticas, associadas a um sistema granítico peraluminosos rico em boro, do tipo LCT. Os dados aqui apresentados permitem concluir que os albititos estudados são de origem magmática, tendo sido formados por cristalização de um magma altamente sódico, sendo que esse magma muito evoluído passou por vários processos de cristalização fracionada. Os tonalitos e monzogranitos mostraram-se também relativamente ricos em $\mathrm{Na}_{2} \mathrm{O}$, o que é evidenciado pela química do plagioclásio. Essa composição pode estar ligada ao baixo grau de fusão de rochas metassedimentares que deram origem a essas rochas. A ordem de cristalização sugerida para as rochas estudadas é monzogranito-tonalito-albitito. Os resultados obtidos no presente trabalho demonstram que, além de conter mineralização de estanho hidrotermal, hospedada em greisens e geneticamente associada ao magmatismo granítico intraplaca de aproximadamente 1,7 Ga, a Província Estanífera de Goiás possui concentrações econômicas de estanho magmáticas, hospedadas em albitito ígneo e formadas por cristalização fracionada de granitos peraluminosos da Suíte Aurumina, de aproximadamente 2,0Ga. Esses resultados, portanto, ampliam as possibilidades de fonte de estanho na Província Estanífera de Goiás e têm implicações para o potencial econômico da Província. Estudos experimentais ou petrológicos adicionais devem ser realizados para avaliar a existência de relação genética entre o magmatismo intraplaca e o magmatismo sincolisional e, por conseguinte, entre a concentração hidrotermal e a magmática de estanho na Província Estanífera de Goiás. Sugerem-se, ainda, estudos 
para verificar o papel dos xistos da Formação Ticunzal na gênese dos granitos peraluminosos e na fonte de estanho na Província Estanífera de Goiás.

Palavras-chave:albitito magmático, Goiás, cassiterita, estanho, textura snowball, granito peraluminoso, isótopos de oxigênio,idade Ar-Ar, Suíte Aurumina. 


\section{ABSTRACT}

The tin-mineralized albitites from the Pelotas and Boa Vista artisanal mines, in the Goiás Tin Province (GTP), cut the granites and tonalities from the Aurumina Suite and schists from the Ticunzal Formation. The albitites consist of albite, quartz, cassiterite, apatite, K-feldspar and primary muscovite. Texturally they contain alignment of albite "laths" and snowball texture, interpreted as typical of albitites from magmatic origin. The tonalites, granites and schists were divided in facies: biotitemuscovite tonalite, muscovite-biotite tonalite, biotite-muscovite monzogranite, muscovite-biotite monzogranite, garnet-chlorite-biotite-quartz schist and graphitechlorite schist. The albitites are metaluminous to peraluminous, while the granites and tonalites are strongly peraluminous. The albitites are enriched in $\mathrm{Na}_{2} \mathrm{O}, \mathrm{Al}_{2} \mathrm{O}_{3}$ and $\mathrm{P}_{2} \mathrm{O}_{5}$, contain moderate levels of $\mathrm{CaO}$ and are depleted in $\mathrm{K}_{2} \mathrm{O}, \mathrm{TiO}_{2}, \mathrm{Fe}_{2} \mathrm{O}_{3}$ and $\mathrm{MgO}$. With respect to trace elements, they are enriched in $\mathrm{Sn}, \mathrm{Ta}, \mathrm{Rb}, \mathrm{Nb}$ and $\mathrm{Zr}$ and depleted in $\mathrm{Sr}$, $\mathrm{Ba}$ and $\mathrm{Th}$. The albitites are enriched in light rare earth elements (LREE) in relation to heavy rare earth elements (HREE). Eu anomalies are absent or very smooth and slightly positive. The tonalites and monzogranites are enriched in $\mathrm{Al}_{2} \mathrm{O}_{3}, \mathrm{TiO}_{2}, \mathrm{Fe}_{2} \mathrm{O}_{3}, \mathrm{MgO}$, $\mathrm{CaO}$ and $\mathrm{K}_{2} \mathrm{O}$ and depleted in $\mathrm{Na}_{2} \mathrm{O}, \mathrm{P}_{2} \mathrm{O}_{5}, \mathrm{SnO}_{2}, \mathrm{TaO}_{2}, \mathrm{Rb}, \mathrm{Nb}$ and $\mathrm{Zr}$. The REE patterns for the granites and tonalite shows enrichment in LREE and depletion in HREE. Eu anomalies for the monzogranites are very discrete and can be slightly positive or negative. The tonalites have a pronounced positive Eu anomaly. Microprobe analyzes allowed classifying the biotite from the muscovite-biotite tonalite and biotitemuscovite monzogranite as siderophyllite, with $\mathrm{Fe} /(\mathrm{Fe}+\mathrm{Mg})$ between 0.58 to 0.71 a.f.u. and $\mathrm{Al}^{\mathrm{IV}}$ content between 2.1 and 3.3 afu. It is compositionally classified as biotite from peraluminous granites. Muscovite from the albitites have high $\mathrm{SiO}_{2}$ and $\mathrm{Na}_{2} \mathrm{O}$ contents and low $\mathrm{MgO}, \mathrm{Fe}_{2} \mathrm{O}_{3}, \mathrm{Al}_{2} \mathrm{O}_{3}$ and $\mathrm{TiO}_{2}$, while muscovite from the biotitemuscovite tonalite facies are enriched in $\mathrm{MgO}, \mathrm{Fe}_{2} \mathrm{O}_{3}, \mathrm{TiO}_{2}$ and $\mathrm{Al}_{2} \mathrm{O}_{3}$ and depleted in $\mathrm{Na}_{2} \mathrm{O}$ and $\mathrm{SiO}_{2}$. The $\mathrm{TiO}_{2}$ values of secondary muscovite are always less than $0.5 \%$. However, primary muscovite has variable amounts of $\mathrm{TiO}_{2}$, from almost zero to $1 \%$. Cassiterite forms strongly pleochroic, twinned and zoned euhedral to subhedral crystals, and has very pure composition, with $\mathrm{Sn}$ being replaced mostly by $\mathrm{Nb}$ and $\mathrm{Ta}$. Plagioclase has composition of albite-oligoclase $\left(\mathrm{Ab}_{77-99} \mathrm{An}_{22-1} \mathrm{Or}_{1}\right)$ in monzogranites and of albite $\left(\mathrm{Ab}_{90-99} \mathrm{An}_{10-0,6} \mathrm{Or}_{0,4}\right)$ in the tonalites and albitites. Apatite is classified as fluorapatite, and is interpreted as igneous. Oxygen isotope data in pairs of albite and 
cassiterite showed thatalbitites were crystallized in a temperature range of $653-1016^{\circ} \mathrm{C}$. The isotopic compositions of the fluid calculated for the albitites, 9.17 to $9.35 \%$ for Pelotas mine and from 8.66 to $9.72 \%$ o for the Boa Vista mine, suggest that the fluid is of magmatic origin. ${ }^{40} \mathrm{Ar} /{ }^{39} \mathrm{Ar}$ values obtained in muscovite from albitite of the Boa Vista mine resulted in plateau age of $1996.55 \pm 12.96 \mathrm{Ma}$, interpreted as the crystallization age of the muscovite. This allows the proposition that albitites have been formed during the Paleoproterozoic, and can be correlated with the late stages of the Aurumina magmatic Suite (2.12 to $2.17 \mathrm{Ga}-\mathrm{U}-\mathrm{Pb}$ zircon). The mineralogical, geochemical and isotopic data obtained in this research allow classify the tin mineralization hosted in the albitites of Pelotas and Boa Vista mines as magmatic, associated with a peraluminous granitic system rich in boron, of LCT type. The data presented here allow conclude that the studied albitites are of magmatic origin, formed by crystallization of a highly evolved and sodic magma, and which underwent various steps of fractional crystallization. Tonalites and monzogranites are also relatively rich in $\mathrm{Na}_{2} \mathrm{O}$, which is evidenced by plagioclase chemistry. This composition may be related to low amount of fusion of the metasedimentary rocks that gave rise to these rocks. The crystallization order suggested for the studied rocks is monzogranite-tonalite-albitite. The results obtained in this study demonstrate that, besides containing hydrothermal tin mineralization, hosted in greisen and genetically associated with the granitic intraplate magmatism of approximately $1.7 \mathrm{Ga}$, the Goiás Tin Province has economic concentration of magmatic tin, hosted in igneous albitite formed by fractional crystallization of peraluminous granites from the Aurumina suite, of approximately 2.0 Ga. These results thus increase the possibilities of tin source in the Goiás Tin Province and have implications for the economic potential of the Province. Additional petrological or experimental studies are encouraged to evaluate the existence of genetic relationship between the intraplate and sin-colisional magmatism and, therefore, between hydrothermal and magmatic concentration of tin in the Goiás Tin Province. Further studies to verify the role of the Ticunzal Formation schists in the genesis of the peraluminous granites and tin in the Goiás Tin Province are also suggested.

Keywords:magmatic albitite, Goiás, cassiterite, tin, snowball texture, peraluminous granite, oxygen isotope, Ar-Ar age, Aurumina Suite. 


\section{CAPITULO I - INTRODUÇÃO}

\section{1 -APRESENTAÇÃO}

A porção nordeste do Estado de Goiás experimentou um primeiro ciclo de extração mineral por volta de 1736, que favoreceu o surgimento dos núcleos populacionais de Monte Alegre de Goiás, Cavalcante e outros. Nas décadas de 1970 e 1980 houve um segundo momento de desenvolvimento devido à extração de cassiterita hospedada em pegmatitos e em granitos, quando a atividade mineira e garimpeira foi bastante intensa. Entretanto, devido à crise mundial do estanho no começo de 1986, garimpos com mineralização em Sn como Boa Vista e Pelotas, por exemplo, foram abandonados.

A Província Estanífera de Goiás (PEG), definida por Marini \& Botelho (1986), abrange uma vasta região do norte do Estado, que se caracteriza pela presença de granitos estaníferos de idade paleo a mesoproterozóica distribuídos em duas subprovíncias: Subprovíncia do Rio Paranã (SRP) e Subprovíncia do Rio Tocantins (SRT). Essas províncias são caracterizadas por apresentar rochas com mineralização hidrotermal e primária de cassiterita.

Rochas ricas em albita são conhecidas em vários depósitos/ocorrências de estanho da Província Estanífera de Goiás, sendo esta constituída por cerca de vinte granitos mineralizados em cassiterita. As mineralizações associam-se a alteração hidrotermal, representada por greisens e granitos albitizados, com destaque para aquelas situadas nas regiões de Monte Alegre de Goiás, Terezina de Goiás e Minaçu. Dois tipos de ocorrência são descritos: a) rochas hidrotermais, albitizadas, como nos granitos Sucuri e Serra Dourada; b) prováveis albititos ígneos, possivelmente produtos de acumulação magmática, associados a granitos e pegmatitos peraluminosos da Suíte Aurumina (Botelho \& Caldas 2010, Botelho \& Moura 1998, Botelho et al. 2006, Mello \& Bilal 2009). Pelo menos três gerações de granitos geneticamente relacionados a estanho foram reconhecidos no Estado do Goiás: granitos peraluminosos paleoproterozóicos sin a pós-tectônicos, granitos paleo-mesoproterozóicos intraplaca e granitos neoproterozóicos sin a tardio-tectônicos (Marini \& Botelho 1986, Pimentel et al. 1991, Botelho \& Moura 1998, Pimentel et al. 1999). 
A discussão sobre a origem de albititos tem ampla divulgação na literatura, principalmente no que diz respeito à origem ígnea ou hidrotermal dessas rochas. Essa discussão tem aplicação importante no estudo de seu potencial metalogenético, com uma tendência a atribuir maior potencial às rochas hidrotermais. Na Província Estanífera de Goiás, são descritas rochas mineralizadas de ambos os tipos, ainda pouco estudadas, o que a torna uma área especial para esse tipo de estudo. Apesar de estudos de várias naturezas realizada na Província, poucos reportam à origem dos albititos e sua relação com as mineralizações de estanho na região.

\section{2- OBJETIVOS}

O estudo das mineralizações de estanho hospedados em albititos na Folha de Porto Real pretendeu caracterizar os principais tipos de rochas ricas em albita associados a mineralizações de estanho na Província Estanífera de Goiás e estabelecer suas relações com os diferentes tipos de granitos e de mineralizações de estanho da Província.

Com os resultados desta pesquisa, pretende-se contribuir tanto para a compreensão da gênese dessas rochas, se de origem magmática ou hidrotermal, quanto para o entendimento de seu potencial para gerar depósitos econômicos de estanho no contexto geológico dessa província específica e de províncias semelhantes.

\section{3- LOCALIZAÇÃO E ACESSO}

A área de estudo está localizada na Folha Porto Real, na porção nordeste do Estado de Goiás. O principal acesso a partir de Brasília se faz pela BR-020 até o entroncamento da GO-118 que segue em direção ao norte, passando por São João d’Aliança e Alto Paraíso. A área de estudo está localizada entre a cidade de Teresina de Goiás e a cidade de Monte Alegre de Goiás, possuía aproximadamente $300 \mathrm{~km}$ de Brasília (Fig. 1.1). 


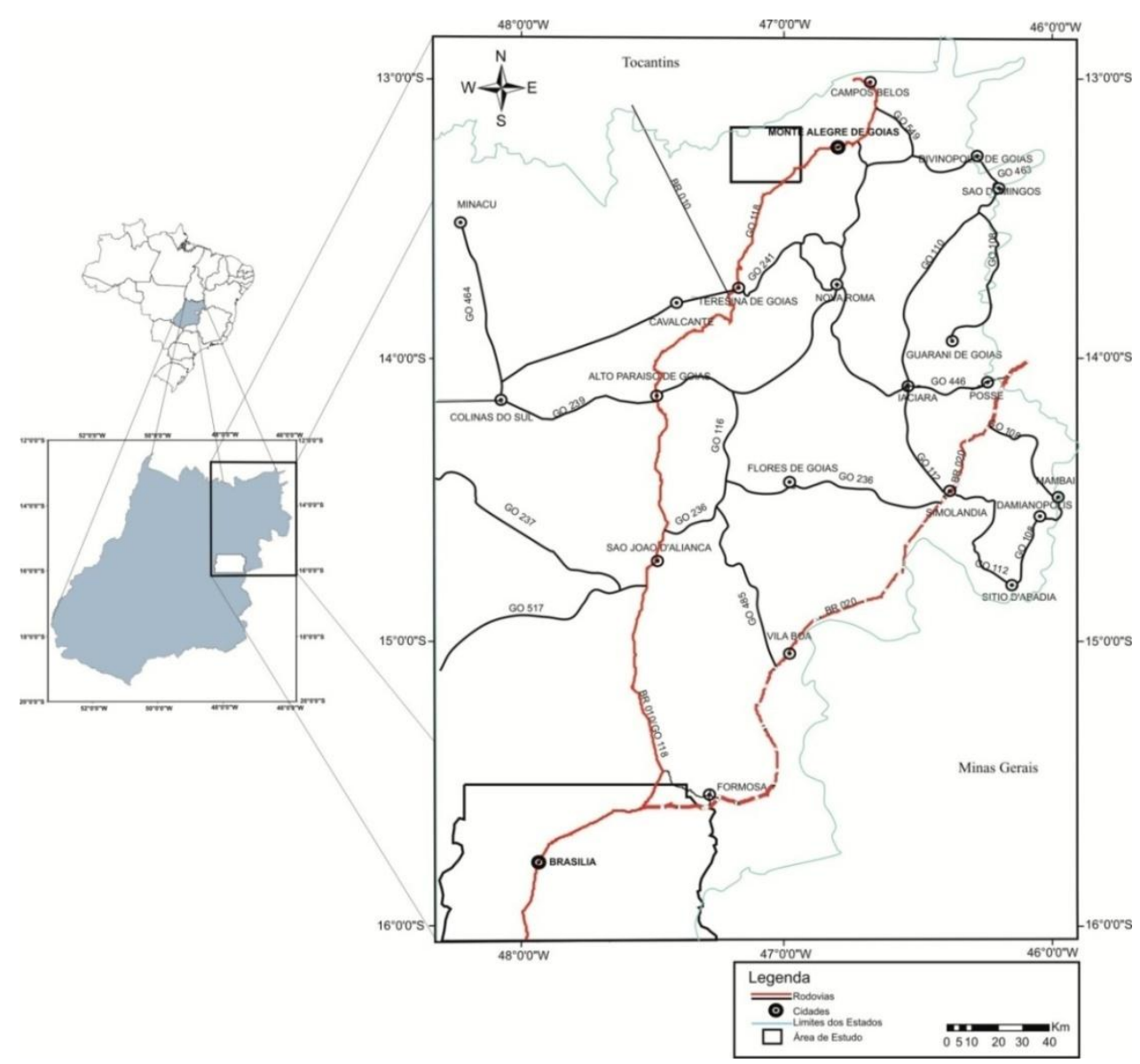

Figura 1.1: Mapa de localização da área de estudo.

\section{4- MÉTODOS}

Para alcançar os objetivos propostos, foram utilizados os métodos descritos a seguir:

\subsection{1 - Revisão Bibliográfica}

Foi realizada uma montagem de acervo de documentos sobre albititos e rochas albitizadas com mineralizações de Sn que ocorrem em diversas regiões do mundo, além de um levantamento bibliográfico sobre a geologia da Província Estanífera de Goiás.

\subsection{2 - Etapas de Campo}

Nessa etapa foram realizadas duas viagens ao campo, para caracterização geológica da área; coleta de amostras de campo no garimpo Pelotas; e descrição e amostragem de furos de sondagens de diferentes garimpos, cedidos pela empresa EDEM (Empresa de Desenvolvimento em Mineração). Foi realizada breve descrição macroscópica para escolha de amostras representativas dos furos. Após a primeira 
amostragem, priorizou-se o estudo do garimpo Pelotas, por possuir albititos mineralizados e furos completos. Foram estudados oito furos do garimpo Pelotas.

Em razão de os garimpos terem sido explorados há muitos anos e as sondagens serem da década de 1980, as informações sobre mapas e perfis, assim como localização dos furos de sondagens, foram perdidas.

\subsection{3 - Petrografia}

Foram realizados estudos de lâminas delgadas polidas em amostras já existentes do garimpo Boa Vista e de lâminas delgadas polidas dos furos de sondagem do garimpo Pelotas, no Laboratório de Microscopia do IG-UnB.

Foram descritas 86 lâminas delgadas polidas, sendo que 54 lâminas foram submetidas a análise visual para estimar as suas composições modais. Destas, 31 foram classificadas como albititos, 13 como monzogranitos, 15 como tonalitos e 4 como xistos. O estudo das lâminas delgadas consistiu na descrição mineralógica e petrográfica detalhada de albititos, tonalitos, monzogranitos e xistos, que subsidiou a escolha de amostras e minerais para estudos petrológicos mais detalhados e análise de química mineral.

\subsection{4 - Química Mineral}

Os dados de química mineral foram obtidos por microssonda eletrônica no equipamento JXA-8230 da Jeol, no Laboratório de Microssonda Eletrônica do IG-UnB. Padrões naturais e sintéticos foram utilizados para a calibração. Os minerais analisados nos albititos foram plagioclásio, apatita, cassiterita e muscovita primária e secundária. Nos monzogranitos e tonalitos, foram analisados biotita, muscovita primária e secundária e plagioclásio.

\subsection{5 - Litogeoquímica}

Com base nos estudos petrográficos, foram selecionadas 21 amostras para análises químicas de rocha total. Os litotipos escolhidos para análises foram albitito, tonalito, monzogranito e xisto. As amostras analisadas foram trituradas em um moinho e pulverizadas em panela de ágata, no Laboratório de preparação de amostras do IGUnB. 
As análises químicas foram realizadas no Laboratório ACME ANALYTICAL LABORATORIES LTDA., sendo os elementos maiores $\left(\mathrm{SiO}_{2}, \mathrm{TiO}_{2}, \mathrm{Al}_{2} \mathrm{O}_{3}, \mathrm{Fe}_{2} \mathrm{O}_{3}\right.$, $\mathrm{MnO}, \mathrm{MgO}, \mathrm{CaO}, \mathrm{Na}_{2} \mathrm{O}, \mathrm{K}_{2} \mathrm{O}, \mathrm{P}_{2} \mathrm{O}_{5}$ ) analisados por ICP-ES (Inductively Coupled Plasma - Emission Spectrometry), após fusão com borato de lítio e digestão ácida. Os elementos-traço (Be, Rb, Cs, Ba, Sr, Ga, V, Sn, W, Ta, Nb, Th, U,Zr, Hf,Y, Sc), incluindo os elementos terras raras ( $\mathrm{La}, \mathrm{Ce}, \mathrm{Pr}, \mathrm{Nd}, \mathrm{Sm}, \mathrm{Eu}, \mathrm{Gd}, \mathrm{Tb}, \mathrm{Dy}, \mathrm{Ho}, \mathrm{Er}, \mathrm{Tm}$, $\mathrm{Yb}$ e $\mathrm{Lu}$ ), foram analisados por ICP-MS (Inductively Coupled Plasma - Mass Spectrometry), após fusão com borato de lítio e digestão ácida. Cr e Co foram analisados individualmente, através do método Leco.

\subsection{6 - Isótopos Estáveis}

Os estudos dos isótopos estáveis foram realizados em pares de cassiterita e albita interpretados como estando em paragênese com base na petrografia, de cinco amostras, sendo três do garimpo Boa Vista e duas do garimpo Pelotas. Os minerais foram separados manualmente no Instituto de Geociências da UnB, em lupa binocular, sendo que para os cristais de albita, foram separados $5 \mathrm{mg}$, e para os cristais de cassiterita, 3 mg por amostra. Foram realizadas análises de isótopos de oxigênio no Laboratório do departamentoGeological Sciences and Geological Engineering, da Queen's University, em Ontário (Canadá), sob coordenação do Professor Dr. Kurt Kyser. As composições isotópicas de oxigênio nos pares de albita e cassiterita foram medidos usando $\mathrm{BrF}_{5}$ pelo método de Clayton e Mayeda (1963). Medições de isótopos estáveis foram realizadas utilizando um espectrômetro de massa Finnigan MAT 252. Todos os valores são apresentados em unidades de permil (\%), os resultados foram apresentados na forma de $\delta^{18} \mathrm{O}$, relativamente ao padrão VSMOW (Viena Standard Mean Ocean Water), a precisão analítica foi de $\pm 0,3 \%$ para os valores de $\delta^{18} \mathrm{O}$.

A equação usada para calcular a temperatura de equilíbrio isotópico para os pares quartzo-cassiterita e cassiterita-água foi:

1- $1000 \ln \alpha=\mathrm{A} \times 10^{6} / \mathrm{T}^{2}+\mathrm{B} \times 10^{3} / \mathrm{T}+\mathrm{C}$, onde $\mathrm{A}=0,56, \mathrm{~B}=5,80$ e $\mathrm{C}=-3,04$ para o par quartzo-cassiterita e $\mathrm{A}=3,68, \mathrm{~B}=-9,58$ e $\mathrm{C}=2,0$ para o par cassiteritaágua, para temperaturas entre 0 e $1200^{\circ} \mathrm{C}$ (Zheng 1991).

A equação usada para calcular a temperatura de equilíbrio isotópico para o sistema albita-água foi: 
2- $1000 \ln \alpha=A+B / T^{2}$ (Bottinga \& Javoy 1973), em que $A=-3,70$ e $B=3,13$, para temperaturas entre 500 e $800^{\circ} \mathrm{C}$.

Para o calculo da composição isotópica de $\mathrm{O}$ do fluido foi usada a seguinte relação:

3- $\delta^{18} \mathrm{O}($ mineral $)-\delta^{18} \mathrm{O}\left(\mathrm{H}_{2} \mathrm{O}\right)=1000 \ln \alpha$

\subsection{7 - Datação ${ }^{40} \mathrm{Ar} /{ }^{39} \mathrm{Ar}$}

A análise geocronológica ${ }^{40} \mathrm{Ar}^{139} \mathrm{Ar}$ foi realizada no Laboratório de Geologia isotópica da Queen's University, Department of the Geological Sciences \& Geological Engineering, Ontário (Canadá), sob a coordenação do Dr. N. A. Archibald. Foi aplicada 23 steps de temperatura em mica do albitito do garimpo Boa Vista, cedidas pelo Professor da UnB Valmir da Silva Souza. As amostras foram irradiadas por cerca de 40 horas em reator nuclear do tipo McMaster. Foi empregado laser de íon específico (Ar) de 8w tipo Lexel 3500. Foi utilizado espectrômetro de massa do tipo MAP 216, com fonte Signer Baur e multicoletor de elétrons. As medidas dos isótopos de argônio são normalizadas à razão atmosférica ${ }^{40} \mathrm{Ar}^{136} \mathrm{Ar}$ usando as razões propostas por Roddick (1983). As idades e os erros foram corrigidos usando as fórmulas propostas por Steiger \& Jäger (1977) e Dalrymple et al. (1981). As idades e erros apresentados possuem precisão analítica de $2 \sigma$ ou $0,5 \%$, adequados ao espectro de variação para a forma de platô (McDougall \& Harrison 1988). As idades obtidas foram referenciadas para o padrão $\mathrm{H}_{\mathrm{b} 3} \mathrm{Gr}$ (hornblenda) em $1072 \mathrm{Ma}$ (Roddick 1983). 


\section{CAPITULO II - GEOLOGIA REGIONAL E LOCAL}

\section{1- CONTEXTO GEOLÓGICO REGIONAL}

\subsection{1- INTRODUÇÃO}

A área de estudo está situada na Província Estanífera de Goiás, dentro da Província Estrutural Tocantins (Fig. 2.1), situada na zona de cinturão de dobras e empurrões. Esta unidade geotectônica é composta pelas sequências supracrustais representadas pelo Grupo Araí, Natividade, Serra da Mesa, Paranoá e Bambuí, e pelo embasamento siálico, representado pelas sequências vulcano-sedimentares, Formação Ticunzal e pela Suite Aurumina, além de Granitos Tipo A da Província Estanifera de Goiás, representada pela Suíte Pedra Branca (Marini \& Botelho 1986).

A Província Estanífera de Goiás (PEG), definida por Marini \& Botelho (1986), abrange uma vasta região do norte do Estado, que se caracteriza pela presença de granitos estaníferos de idade paleo-mesoproterozóica distribuídos em duas subprovíncias: Subprovíncia do Rio Paranã (SRP) e Subprovíncia do Rio Tocantins (SRT), é composta por cerca de vinte corpo graníticos, caracterizadas por apresentar rochas com mineralização hidrotermal e primária de cassiterita, são formados pelos corpos graníticos Pedra Branca, Mocambo, Mangabeira, Mendes, Sucuri e Soledade, que são intrusivos na Suíte Aurumina e na Formação Ticunzal (Marini \& Botelho, 1986, Marini et al. 1992), são enriquecidos em Sn e In, classificado em famílias g1 e g2 (Botelho 1992), e datadas pelo método U-Pb em 1,77 e 1,58 Ga respectivamente (Pimentel et al. 1991).

A Formação Ticunzal (Marini 1978) representa um espesso pacote de rochas metassedimentares, composto principalmente por paragnaisses e micaxistos grafitosos, com finas camadas de metarcoseos e quartzitos micaceos, que se distribui por grande parte da região centro-leste do Estado de Goiás. A Suíte Aurumina é caracterizada por granitos e tonalitos peraluminosos de idade Paleoproterozoica, entre 2,0 e 2,2 Ga (Botelho et al.1999).

Os primeiros granitos atribuídos à Suíte Aurumina afloram na região entre a cidade de Teresina de Goiás e Cavalcante, onde são encontradas intrusões concordantes com a foliação da Formação Ticunzal, estendendo-se ainda para regiões de Nova Roma e Monte Alegre de Goiás (Botelho et al. 1999). 
Rochas albitizadas e albititos relacionados a mineralizações de estanho da Província Estanífera de Goiás: caracterização petrológica e gênese.

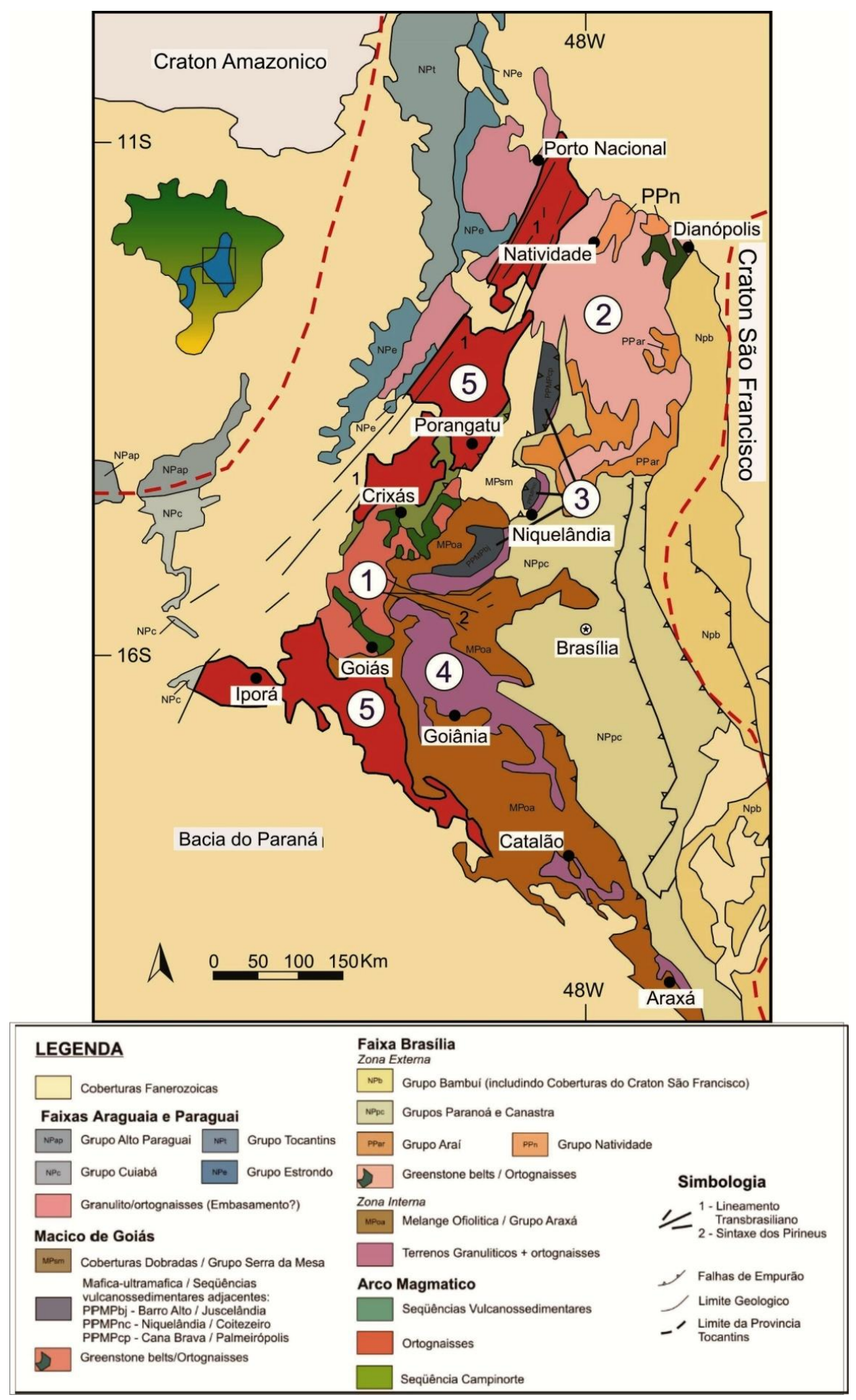

Figura 2.1: Mapa geológico da Província Estrutural de Tocantins (Marini et al. 1984, Fuck et al.1994). 


\section{2- GEOLOGIA DA ÁREA}

As unidades geológicas identificadas na área de estudo são a Formação Ticunzal e a Suíte Aurumina.

\subsubsection{Formação Ticunzal}

A Formação Ticunzal tem a sua área-tipo na região das serras do Ticunzal e Tombador, no município de Cavalcante (Marini et al. 1978, Fernandes 1982). A distribuição dessa seqüência no contexto da Faixa Brasília ainda provoca controvérsias, mas trabalhos recentes têm demonstrado sua presença em uma vasta área do nordeste de Goiás e sudeste de Tocantins (Botelho et al. 2002, Botelho \& Portela 2005). O conjunto de rochas metassedimentares e granitos peraluminosos intrusivos da Suíte Aurumina apresenta-se intensamente deformado, num domínio rúptil-dúctil, parte da controvérsia sendo decorrente da dificuldade em diferenciar milonitos orto e paraderivados.

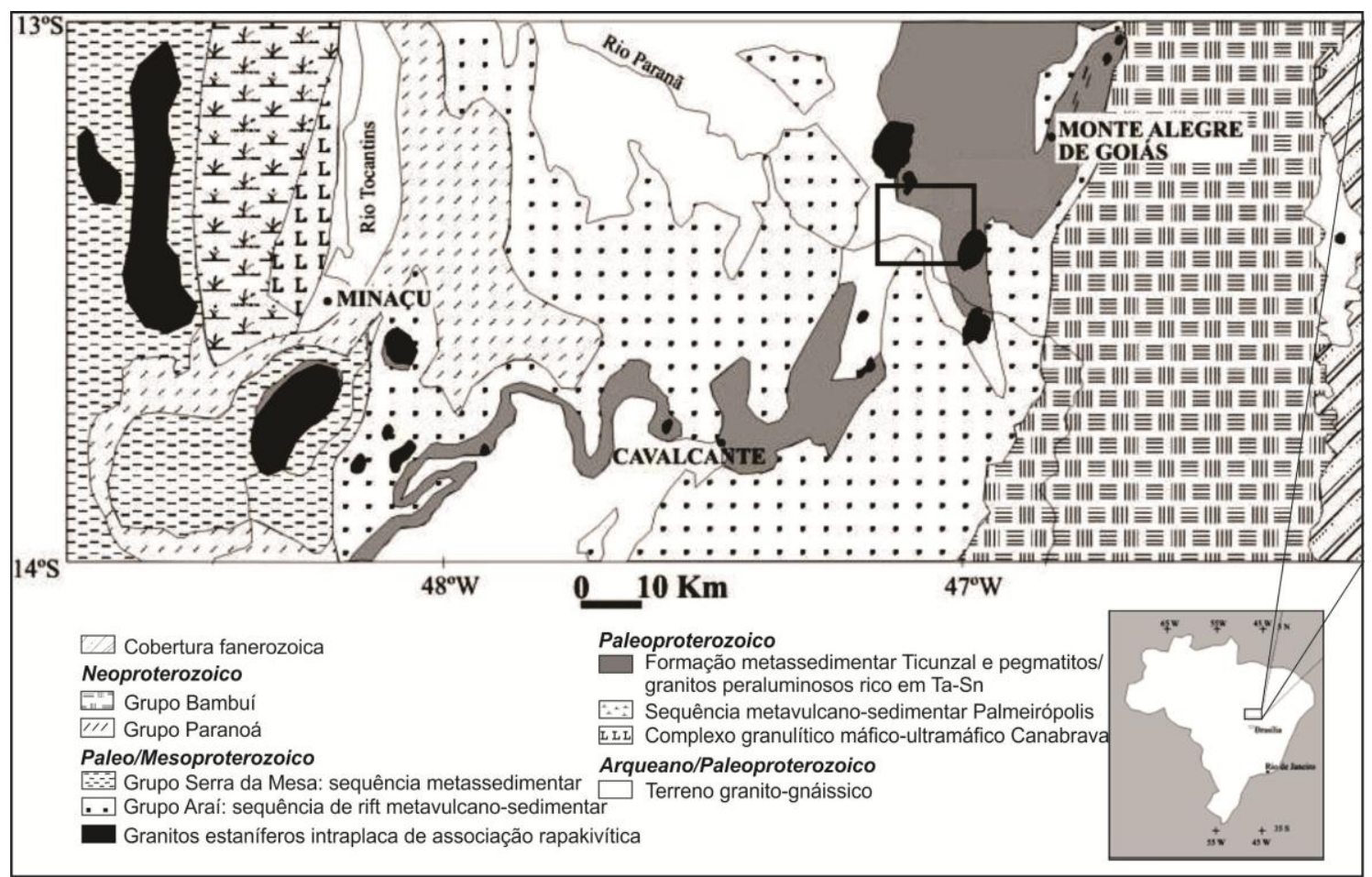

Figura 2.2: Mapa geológico da região nordeste de Goiás, com destaque para a área estudada (Moura et al. 2014).

Essa formação representa um espesso pacote de rochas metassedimentares, compostos principalmente por paragnaisses e micaxistos grafitosos, com finas camadas de metarcóseos e quartzitos micáceos, que se distribui por grande parte da região centroleste do estado de Goiás. 
As rochas mais comuns são os xistos grafitosos associados a mica-quartzo xisto, granada-mica xisto e biotita gnaisse. Sua característica mais marcante é a presença de grande quantidade de grafita, que sugere ambiente de sedimentação marinho restrito de águas quentes e salgadas com alta atividade biológica. As assembléias mineralógicas pertencentes a essa formação com grafita e fenoblastos de granada indica metamorfismo da fácies anfibolito, embora também apresente retrometamorfismo na fácies xisto verde. Nas bordas das intrusões das Suítes Aurumina e Pedra Branca também ocorre metamorfismo de contato, dando origem a auréolas com andaluzitas (Alvarenga et al. 2007).

$\mathrm{Na}$ parte nordeste do Estado de Goiás (Fig. 2.2), os xistos grafitosos da Formação Ticunzal hospedam urânio, tanto em veios quanto associados a falhas. A idade da Formação Ticunzal é mais antiga que 2,17 Ga, que é a idade das intrusões graníticas mais antigas da Suite Aurumina nela identificadas. Dados isotópicos de Sm$\mathrm{Nd}$ indicam uma idade-modelo entre 2,7 e 2,8 Ga (Pimentel et al. 2004), que caracterizam o pacote metassedimentar como sendo de idade neoarqueana/paleoproterozóica.

As rochas da Formação Ticunzal encontradas na área, identificadas em testemunho de sondagem do garimpo Pelotas,foram os xistos, os quais são divididos em duas fácies litológicas: granada-biotita-clorita-quartzo xisto e grafita-clorita xisto. Esses litotipos são cortados pelos monzogranitos e tonalitos da Suíte Aurumina. São rochas com textura lepidoblástica, compostas por quartzo (15-55\%), plagioclásio (0-5\%) quase que totalmente substituído por sericita, muscovita (25-33\%), granada (0-1\%), biotita (0$2 \%$ ), epidoto $(0-0,5 \%)$, clorita $(5-45 \%)$ e grafita (4-10\%), sendo este último mineral muito característico dessas rochas. A xistosidade é marcada principalmente pelos lamelas de muscovita e clorita.

\subsubsection{Suíte Aurumina}

Os granitos peraluminosos foram reunidos sob a denominação de Suíte Aurumina por Botelho et al. (1999). A Suíte Aurumina está inserida no contexto geológico da Subprovíncia Estanífera Paranã e tem a sua maior área de exposição na região de Teresina de Goiás e Cavalcante, estendendo-se ainda para a região de Monte Alegre de Goiás. Esses granitos são a encaixante do depósito de ouro de Aurumina, que está hospedado em veios de quartzo, das ocorrências de Sn-Ta na região de Porto Real, 
nas proximidades do Rio Paranã, e dos greisens e pegmatitos dos depósitos de $\mathrm{Sn}$-Ta de Monte Alegre de Goiás. Os granitos com predominância de muscovita são tipicamente sin-tectônicos,apresentando-se intrusivos e deformados concordantemente com a foliação de rochas metassedimentares atribuídas à Formação Ticunzal. Nos tonalitos, a deformação é incipiente e as relações de campo indicam que se trata de uma fase tardia da granitogênese, com características claramente tardi a pós-tectônicas.

A Suíte Aurumina é composta por muscovita monzogranitos, muscovita-biotita monzogranitos, tonalitos, biotita sienogranitos e leucogranitos e pegmatitos com turmalina. Segundo Botelho et al. (1999), os granitos da Suíte Aurumina apresentam coloração cinza, granulação média a grossa e foliação proeminente, sua composição é representada por quartzo, microclínio pertítico, plagioclásio, biotita e muscovita, com enclaves de grafita. A Suíte Aurumina está subdividida em seis fácies, incluindo rochas graníticas sin-, tardi- e pós-tectônicas, a saber: muscovita granito, biotita-muscovita granito, tonalito, biotita granito, migmatitos e turmalina-muscovita granito. Apenas as fácies muscovita granito e tonalito afloram na área de estudo.

São granitos paleoproterozóicos (2,12-2,17 Ga - U-Pb em zircão), sincolisionais e peraluminosos do tipo-S (Botelho et al. 2006). Os granitos mais antigos $(\sim 2,17 \mathrm{Ga})$ da Suíte Aurumina são intrusivos de forma concordante com a foliação das rochas metassedimentares da Formação Ticunzal (Botelho et al. 1999, Dardenne \& Schobbenhaus 2001), enquanto que os mais jovens ( 2,12 Ga) são intrusivos de forma discordante tanto com a Formação Ticunzal quanto com os milonitos dos granitos mais antigos (Moura \& Silva 2005). Em comparação com os granitos paleoproterozóicos metaluminosos da Suíte Pedra Branca $\varepsilon N d(T=1,8)$ entre +3 e -11 e TDM entre 2,0 e 2,5 Ga (Pimentel \& Botelho 2001), a fonte dos magmas peraluminosos da Suíte Aurumina é predominantemente arqueana, com pequeno retrabalhamento crustal.

As rochas da Suíte Aurumina que ocorrem na área de estudo foram identificadas como tonalitos e monzogranitos. Os tonalitos foram divididos em duas fácies: biotitamuscovita tonalito e muscovita-biotita tonalito. Os mozogranitos foram divididos em duas fácies: biotita-muscovita monzogranito e muscovita-biotita monzogranito.

Os albititos presentes no garimpo Pelotas ocorrem algumas vezes em contato brusco com as demais rochas, cortando os xistos, tonalitos e monzogranitos, como observado em alguns furos de sondagem (Fig. 2.3 e Fig. 3.3A), o que permitiu interpretá-los como sendo diques de albititos. A profundidade em que se encontram nos 
furos analisados varia entre 17,00 e 36,40 m. Apresentam disseminações de apatita e concentrações de cassiterita. Neste garimpo também ocorre uma variedade de albitito mais enriquecida em quartzo e com presença de K-feldspato, sendo este ultimo como mineral acessório.

Os albititos localizados no garimpo Boa Vista apresentam as mesmas características mineralógicas e texturais dos albititos do garimpo Pelotas. Entretanto, são mais enriquecidos em cassiterita e apatita. Occorrem em contato com as rochas da Suíte Aurumina. 


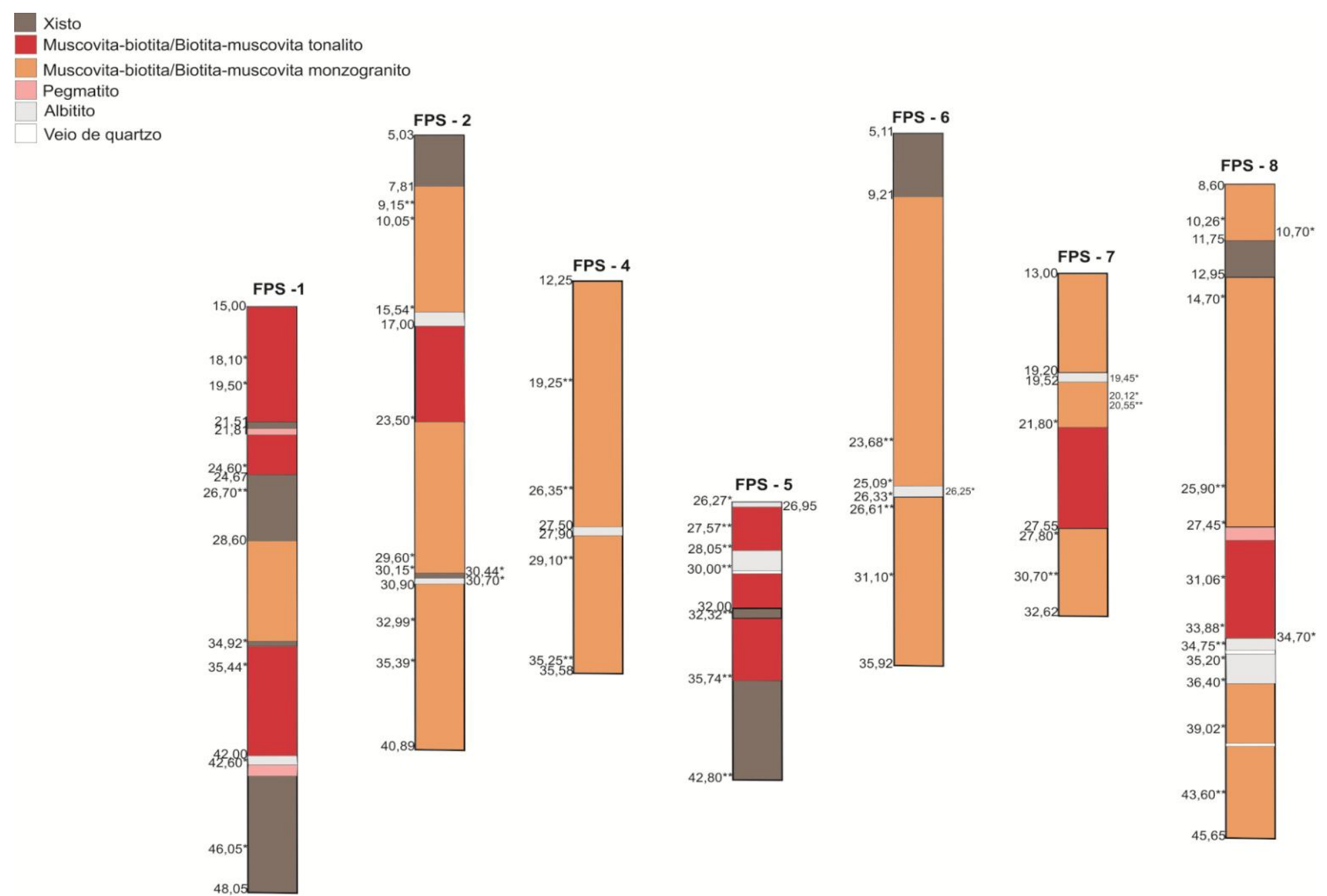

Figura 2.3: Perfil esquemático dos furos de sondagem do garimpo Pelotas, mostrando a variação litológica de cada furo, com base em análise macroscópica, microscópica e química. As profundidades com apenas um asterisco $(*)$ indicam a localização das amostras com estudo petrográfico; as profundidades com dois asteriscos $(* *)$ indicam a localização das amostras com estudo petrográfico e análise química. 

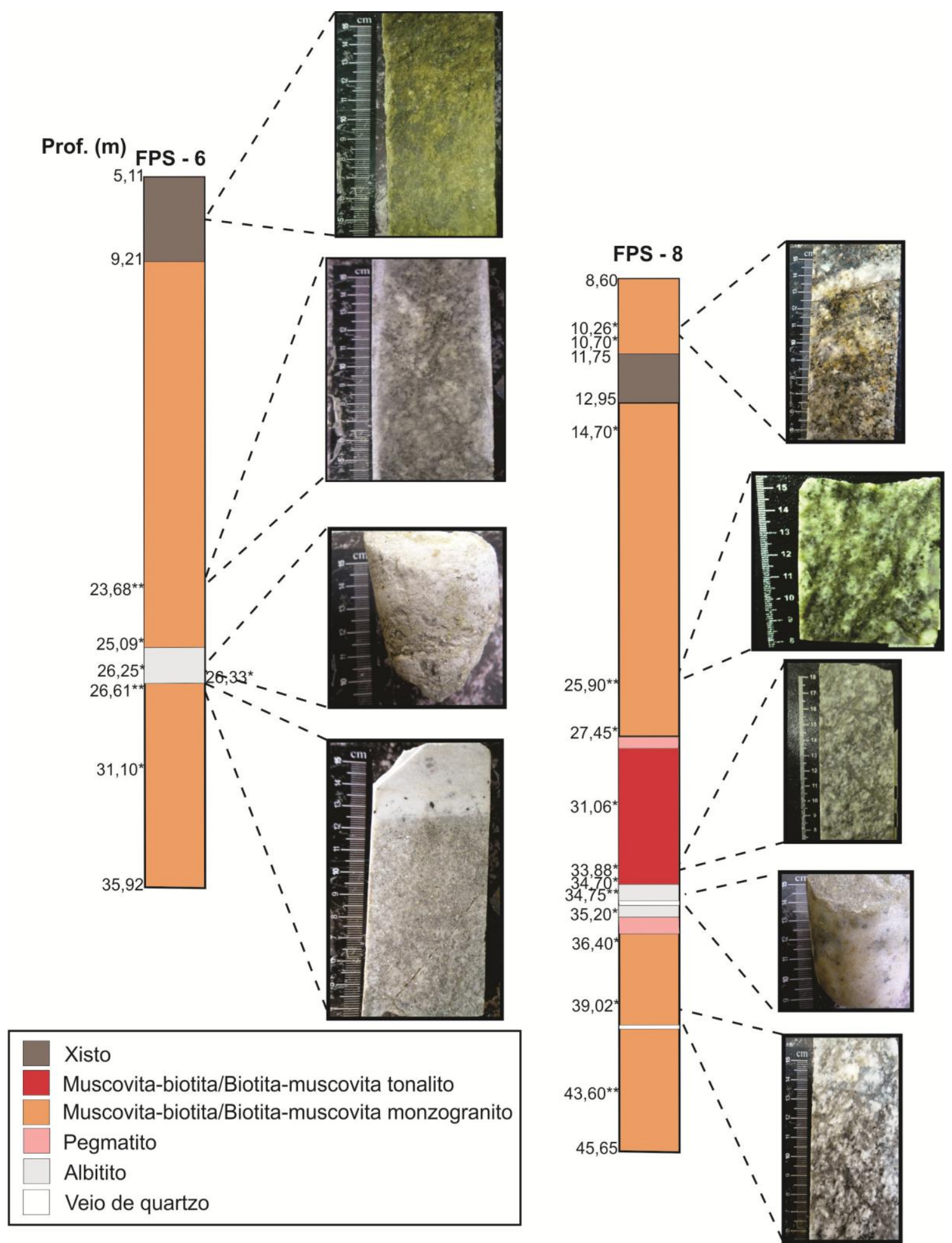

Figura 2.4: Perfil esquemático dos furos de sondagem FPS-6 e FPS-8 do garimpo Pelotas, mostrando detalhe dos principais litotipos descritos. As profundidades com apenas um asterisco (*) indicam a localização das amostras com estudo petrográfico; as profundidades com dois asteriscos (**) indicam a localização das amostras com estudo petrográfico e análise química. 


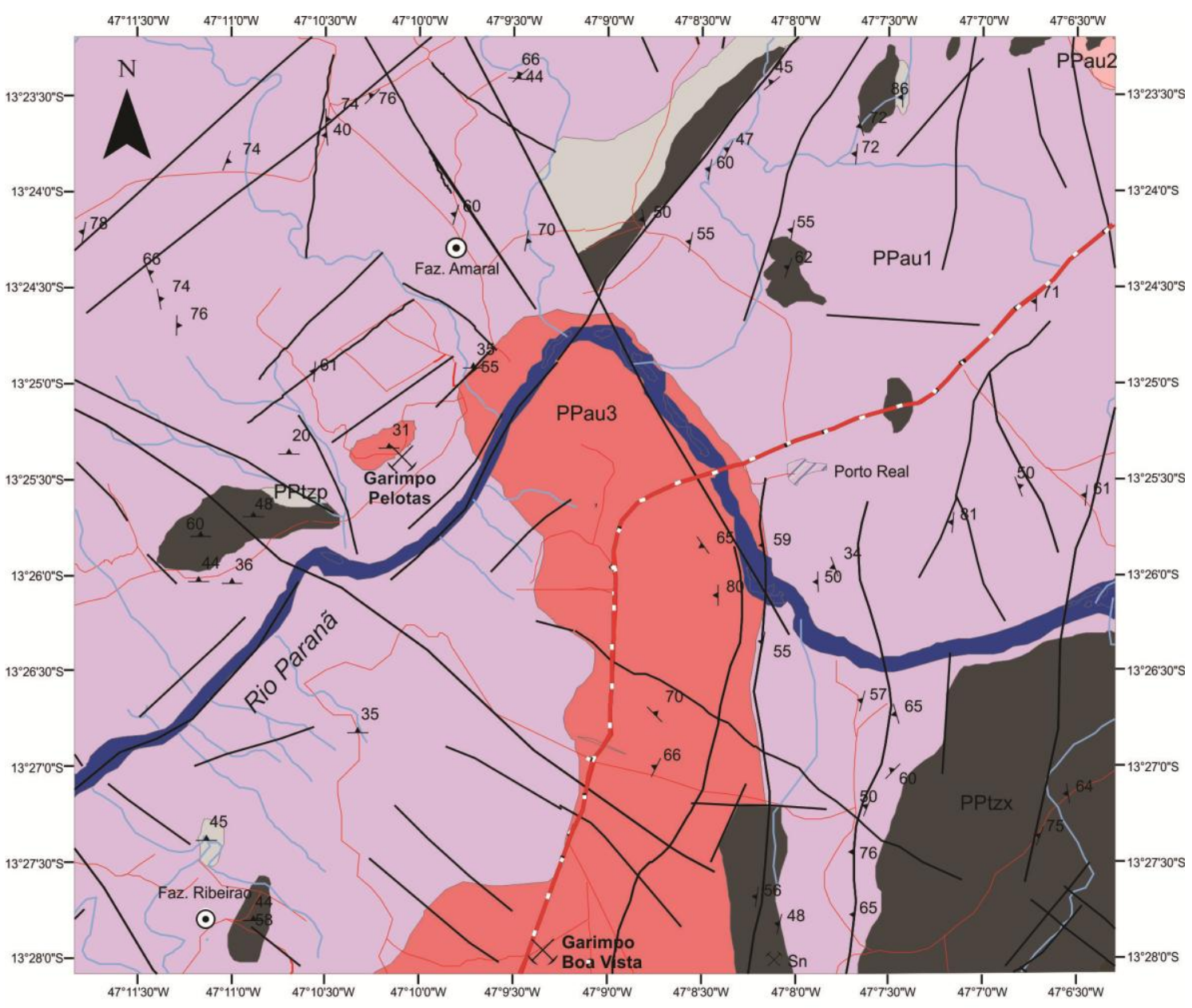

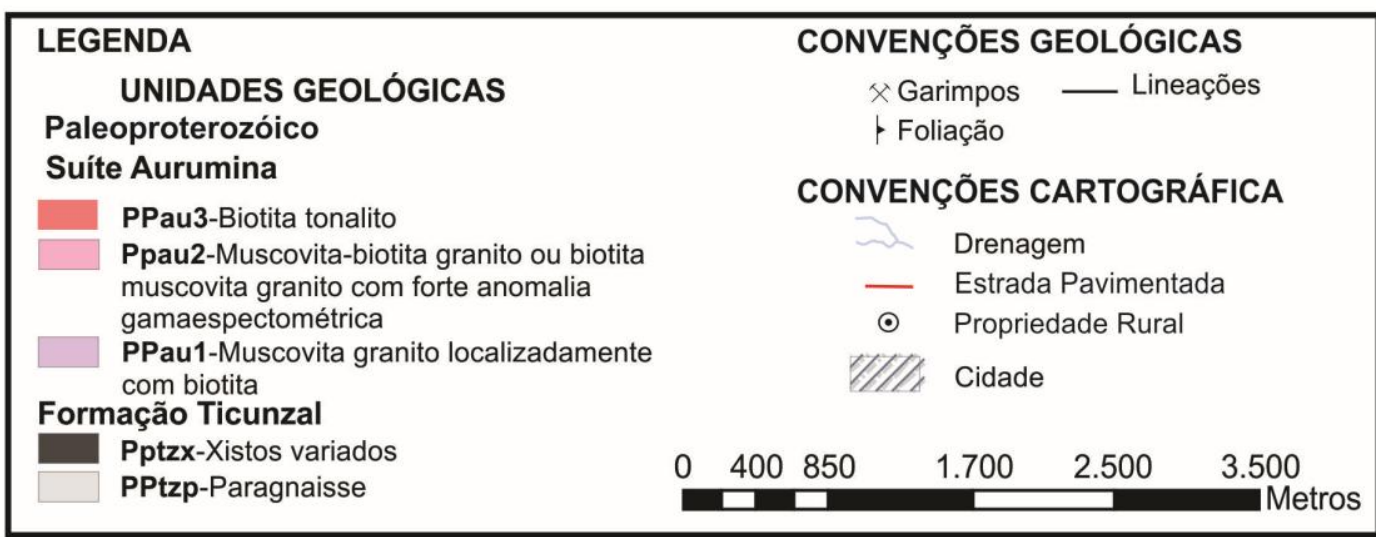

Figura 2.5: Mapa geológico da área da região de Porto Real, mostrando a localização dos garimpos Pelotas e Boa Vista (Trabalho Final, UnB 2005). 
CAPITULO III - ALBITITOS DA PROVÍNCIA ESTANÍfERA DE GOIÁs: PETROLOGIA, GEOQUÍMICA ISOTÓPICA E GÊNESE

\subsection{INTRODUÇÃ̃O}

Os albititos são rochas constituídas de plagioclásio, de composição albita a albita-oligoclásio, em porcentagem volumétrica estimada igual ou superior a $70 \%$ (Prates\& Fuzikawa 1985). Os albititos que ocorrem na região de estudo são associados a granitos peraluminosos e a xistos, e são mineralizados em Sn. A cassiterita ocorre de forma disseminada.

Existe grande discussão na literatura sobre a origem dos albititos. Alguns albititos têm origem atribuída à ação de fluidos hidrotermais em granitos. Esse tipo de albitito normalmente se forma ao longo de fraturas em granitos evoluídos e se caracteriza por lixiviação do quartzo do protólito e deposição de novos minerais (Leroy \& Turpin 1988, Guanhuet al. 1997, Castorina et al. 2006, Mohammad et al. 2007, Kaur et al.2008). Comumente mostra características de sobreposição de fases hidrotermais e supergênicas. Um tipo subordinado de albitito é representado por cristalização direta a partir de magmas ricos em sódio, denominado de albitito ígneo. Este tipo pode ser reconhecido por típicas texturascomo: a) arranjo de inclusões de crescimento de albita ao longo dos planos de quartzoou outro mineral, denominada de textura snowball (Schwartz 1992, Helba et al. 1997), com forma subedral a euedral e com extinção ondulante da albita (Wang et al. 2014); b) e por textura de fluxo, caracterizada por alinhamento das ripas de albita na matriz.

Depósitos de estanho exibem uma vasta faixa estrutural e tipos mineralógicas (Taylor 1979) e são geralmente espacialmente relacionados a intrusões de granito alojados em níveis rasos (1-4 km) na crosta. Essas intrusões ocorrem em diversos ambientes tectônicos, são compostas de diferentes tipos de magma (peralcalino ou peraluminoso) e são quimicamente especializadas (Tischendorf 1977).

O presente estudo foi realizado nos garimpos de Boa Vista e Pelotas, localizados na folha Porto Real, próximo à cidade de Monte Alegre de Goiás, na porção nordeste do Estado de Goiás. Serão discutidas neste trabalho a petrologia e a gênese dessas rochas com base em estudos geológicos, petrográficos, geoquímicos, de química mineral e de 
isótopos de oxigênio. Será também apresentada e discutida datação ${ }^{39} \mathrm{Ar} /{ }^{40} \mathrm{Ar}$ em muscovita dos albititos.

\subsection{PETROGRAFIA}

O estudo petrográfico possibilitou identificar os seguintes tipos de rocha: xisto, monzogranito, tonalito, pegmatito e albitito. As análises visuais estimadas das rochas encontram-se na Tabela 3.1. No garimpo Boa Vista, foram descritos apenas albititos, os quais são mais enriquecidos em cassiterita do que os albititos do garimpo Pelotas, ao passo que no garimpo Pelotas foi estudado tanto o albitito quanto as demais rochas citadas acima.

Os xistos foram divididos em granada-biotita-clorita-quartzo xisto e grafitaclorita xisto. As análises visuais estimadas de 24 amostras de granitos foram plotadas nos diagramas Q-A-P e Q-(A+P)-M de Streckeisen (1976), (Fig. 3.1). Os granitos estudados possuem composição variando de tonalítica a monzogranítica. Os tonalitos foram divididos em biotita-muscovita tonalito e muscovita-biotita tonalito. Os monzogranitos foram divididos em biotita-muscovita monzogranito e muscovita-biotita monzogranito. Essas rochas texturalmente são bastante semelhantes, sendo diferenciadas apenas pela abundância de alguns minerais.

\subsubsection{XISTOS}

Os xistos foram observados nos furos FPS1, FPS2, FPS6 e FPS8 em profundidade rasa, na maioria das vezes. Ocorrem, por vezes, próximos aos albititos, sendo observado, em lâmina, o contato entre os albititos e o xisto apenas no furo FPS1. São divididos em duas fácies: granada-biotita-clorita-quartzo xisto e grafita-clorita xisto.

\section{Granada-biotita-clorita-quartzo xisto}

O granada-biotita-clorita-quartzo possui granulação variando de 0,1 a $2 \mathrm{~mm}$, e coloração cinza-escuro. É composto por quartzo (55\%), muscovita (33\%), granada $(1 \%)$, biotita (2\%), grafita (4\%) e clorita $(5 \%)$.

Os cristais de quartzo apresentam na maioria das vezes, alongados seguindo a foliação da rocha, e extinção ondulante. Possuem tamanho variando de 0,1 a 2,5 mm. 
Comumente apresentam contatos serrilhados com os demais minerais. Alguns cristais estão recristalizados com tamanho muito fino.

A muscovita ocorre orientada juntamente com os cristais de quartzo, caracterizando a textura lepidoblástica. As lamelas de clorita são bem marcantes, estãoassociadas com muscovita e biotita, e estão orientadas paralelamente à xistosidade da rocha. A biotita é fina e é equigranular, altera para clorita. A granada é sinmetamórfica. Os cristais porfiroblastos possuem tamanho médio de $2 \mathrm{~mm}$, são subedrais. As fraturas são preenchidas por muscovita e clorita. As lamelas de grafita estão alinhadas à xistosidade da rocha. Possuem $1 \mathrm{~mm}$ de comprimento (Fig.3.2e).

\section{Grafita-clorita xisto}

O grafita-clorita xisto é cinza-escuro e apresenta granulação de aproximadamente $1 \mathrm{~mm}$ e textura lepidoblástica. Contém muscovita (25\%), clorita $(50 \%)$, grafita (10\%), quartzo (15\%) além de, em menor proporção, calcopirita (tr) e pirita (tr).

A clorita ocorre por toda a rocha. Apresenta pleocroísmo de incolor a verde claro. Ocorre associada à muscovita, apresentando orientação. A grafita tem hábito euedral a subedral, ocorre associado a clorita. As lamelas estão estiradas paralelamente à xistosidade da rocha. Os cristais de quartzo possuem tamanho de $1 \mathrm{~mm}$, com hábito anedrale com contatos serrilhados e contorno irregular. Apresentam extinção ondulante, interpretada como resultante de deformação. A muscovita possui textura lepidoplástica e está associada à clorita. É o principal mineral que compõe a matriz micácea e raramenteforma lamelas maiores que se destacam na matriz. Os sulfetos são geralmente formados por pirita, calcopirita, com hábito anedral. Ocorrem apenas como mineral acessório. 
Tabela 3.1: Composições modais médias estimadas das rochas estudadas. Abreviações: (p) primários; (s) secundários; (tr) mineral-traço. MBT: Muscovita-biotita tonalito; BMT: Biotita-muscovita tonalito; MBM: Muscovita-biotita monzogranito; BMM: Biotita-muscovita monzogranito; GCBQX: Granadaclorita-biotita-quartzo xisto; GCX: Grafita-clorita xisto.

\begin{tabular}{|c|c|c|c|c|c|c|c|c|}
\hline \multirow{3}{*}{$\begin{array}{c}\text { GARIMPO } \\
\text { Minerais } \\
\begin{array}{c}(\%) / \text { Tipos de } \\
\text { rocha }\end{array} \\
\end{array}$} & BOA & \multicolumn{7}{|c|}{ PELOTAS } \\
\hline & \multirow{2}{*}{\multicolumn{2}{|c|}{ Albitito }} & \multicolumn{2}{|c|}{ Tonalitos } & \multicolumn{2}{|c|}{ Monzogranitos } & \multicolumn{2}{|c|}{ Xistos } \\
\hline & & & BMT & MBT & BMM & MBM & GCBQX & GCX \\
\hline $\begin{array}{l}\text { Numero de } \\
\text { lâminas } \\
\text { analisadas }\end{array}$ & 19 & 12 & 9 & 6 & 7 & 6 & 2 & 2 \\
\hline Quartzo & 3,5 & $3,0-23$ & 37,5 & 31 & 30 & 24 & 65 & 15 \\
\hline $\begin{array}{l}\text { Albita- } \\
\text { oligoclásio }\end{array}$ & 90 & $91-73$ & 47,5 & 58 & 34 & 36,5 & - & 5 \\
\hline K-Feldspato & - & $0-1$ & 5 & 3 & 30 & 28 & - & - \\
\hline Biotita & - & - & 1 & 2 & 2 & 4 & 2 & - \\
\hline Cassiterita & 2 & 1 & - & - & - & - & - & - \\
\hline Apatita & 2 & $0-1$ & - & - & - & - & - & - \\
\hline Muscovita $^{(p)}$ & 2 & $0-4$ & 5 & 1 & 2 & 1 & 33 & 25 \\
\hline Muscovita $^{(\mathrm{s})}$ & 0,5 & $0-2$ & 2 & 3 & 1 & 3 & - & - \\
\hline Turmalina & - & - & - & - & $\operatorname{tr}$ & - & - & - \\
\hline Granada & - & - & - & - & - & 0,5 & 1 & - \\
\hline Zircão & $\operatorname{tr}$ & - & $\operatorname{tr}$ & $\operatorname{tr}$ & $\operatorname{tr}$ & $\operatorname{tr}$ & - & - \\
\hline Epidoto $^{(\mathrm{s})}$ & - & - & $\operatorname{tr}$ & - & 0,5 & 1 & - & - \\
\hline Zoisita $^{(\mathrm{s})}$ & - & - & $\operatorname{tr}$ & - & 0,5 & 1,5 & - & - \\
\hline Clinozoisita $^{(\mathrm{s})}$ & - & - & - & - & $\operatorname{tr}$ & - & - & - \\
\hline Carbonato & - & - & - & - & - & $\operatorname{tr}$ & - & - \\
\hline Pirita & - & - & $\operatorname{tr}$ & 0,5 & $\operatorname{tr}$ & 0,5 & - & $\operatorname{tr}$ \\
\hline Calcopirita & - & - & 0,5 & 0,5 & 0,5 & 0,5 & - & $\operatorname{tr}$ \\
\hline Grafita & - & - & 0,5 & $\operatorname{tr}$ & $\operatorname{tr}$ & $\operatorname{tr}$ & 4 & 10 \\
\hline Monazita & - & - & $\operatorname{tr}$ & - & - & $\operatorname{tr}$ & - & - \\
\hline Clorita & - & - & 1 & - & 0,5 & 0,5 & 5 & 50 \\
\hline Titanita & - & - & $\operatorname{tr}$ & $\operatorname{tr}$ & - & - & - & - \\
\hline Rutilo & - & - & - & - & $\operatorname{tr}$ & - & - & - \\
\hline
\end{tabular}




\subsubsection{MONZOGRANITO}

\section{Biotita-muscovita/Muscovita-biotita monzogranito}

As fácies biotita-muscovita monzogranito e muscovita-biotita monzogranito apresentam as mesmas características texturais e os mesmos minerais. A única diferença é em relação à alternância nos conteúdos modais da biotita e muscovita. Em decorrência desse fato, optou-se por descrevê-las juntas. Essas fácies apresentam semelhanças texturais e mineralógicas com as fácies biotita-muscovita/muscovita-biotita tonalito. A única diferença ocorre na quantidade de K-feldspato, chegando a $30 \%$.

Macroscopicamente, apresentam textura fanerítica, com coloração cinzaesbranquiçado. Microscopicamente, possuem textura inequigranular hipidiomórfica e, localmente, textura mirmequítica. Há formação de pertitas nos cristais de microclínio. Apresentam, também, forte alteração do plagioclásio para sericita. A deformação varia de fraca a moderada,resultando em quartzo com extinção ondulante ou recristalizado. $\mathrm{O}$ plagioclásio possui natureza sódica (albita e/ou oligoclásio), $\mathrm{An}_{(22-1 \%)}$, determinada por análise em microssonda eletrônica. O monzogranito é constituído, essencialmente, de quartzo (24-30\%), albita-oligoclásio(34-36,5\%) e microclínio (28-30\%) como minerais essenciais; muscovita (1-2\%) e biotita (2-4\%) como minerais varietais; grafita (tr), calcopirita $(0,5 \%)$, pirita $(0,5 \%)$, granada $(0,5 \%)$ e zircão (tr) como minerais acessórios; e, por fim, muscovita (1-3\%), epidoto $(0,5 \%)$, zoisita $(0,5-1,5 \%)$, rutilo (tr) e clorita $(0,5 \%)$ como minerais secundários.

Os cristais de plagioclásio apresentam hábito subedral, inequigranular, com tamanho variando de 0,3 a $3,5 \mathrm{~mm}$ e com contatos serrilhados e reentrantes entre si e com os demais minerais e, por vezes, sub-retilíneos, com contorno irregular. Possuem geminação polissintética com maclas do tipo albita e, mais raramente, com maclas do tipo albita-periclina, porém suas maclas são pouco nítidas devido à forte alteração sericítica sofrida pela rocha. Alteram para quartzo e muscovita. Localmente, apresentam textura mirmequítica (Fig.3.2b). 


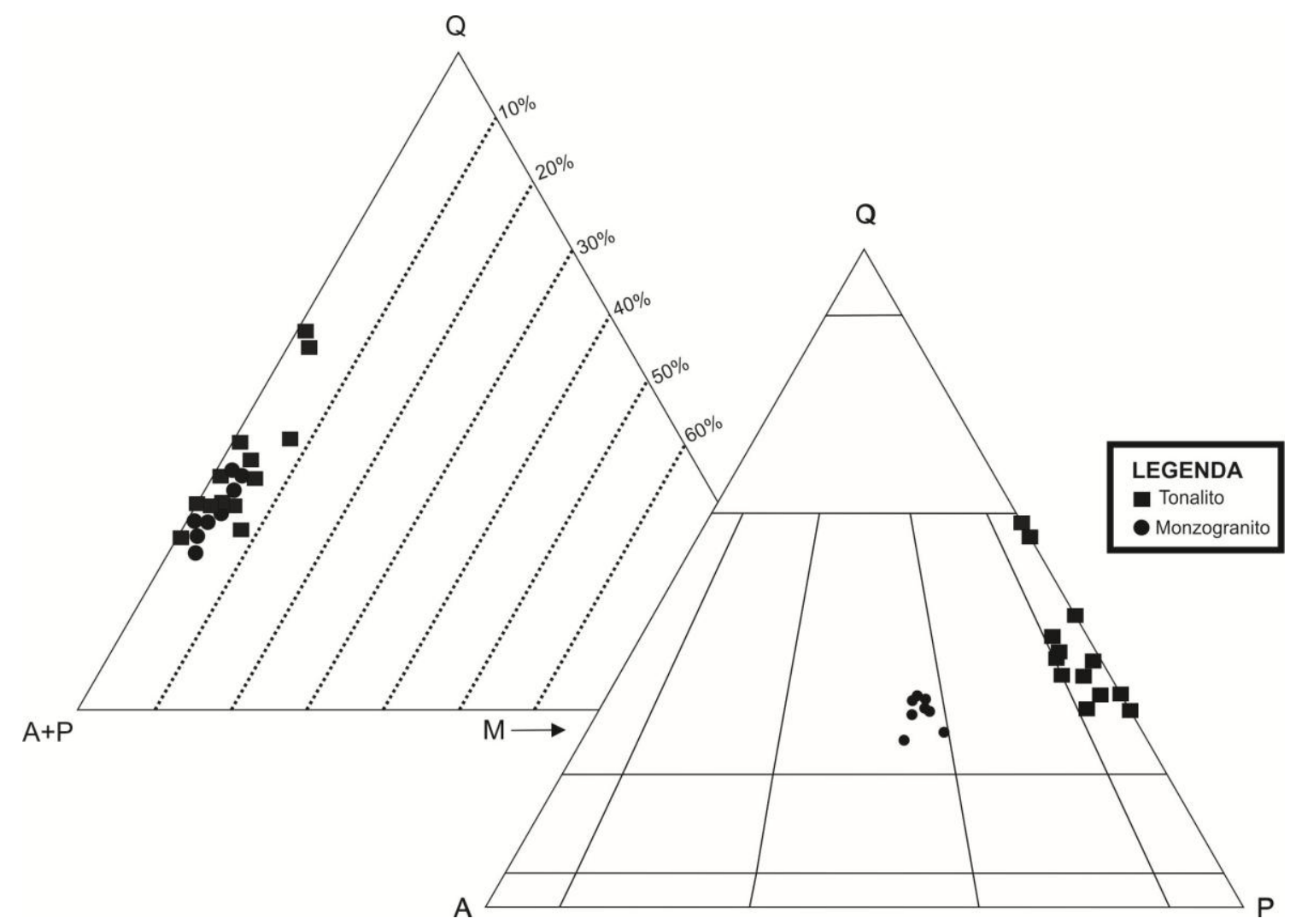

Figura 3.1: Diagramas Q-A-P e Q-(A+P)-M' (Streckeisen, 1976), mostrando a variação composicional dos granitos do Garimpo Pelotas.

Os cristais de quartzo se apresentam como cristais anedrais, inequigranulares, com tamanho variando de 0,1 a 4,0 $\mathrm{mm}$. Esse mineral ocorre em três variedades de

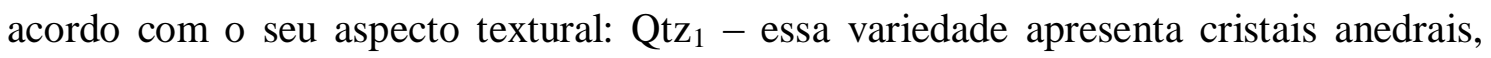
com contatos serrilhados e reentrantes entre si e contorno irregular. Possui extinção ondulante, variando de moderada a forte, que, por vezes, evolui para bandas de deformação. Alguns cristais apresentam forma alongada definindo uma orientação preferencial. $\mathrm{Qtz}_{2}$ - essa variedadeapresenta cristais anedrais, contatos serrilhados entre si e com os demais minerais e contorno irregular. Apresenta extinção reta, portanto, sendo afetada com menos intensidade pelo processo de deformação, uma vez que se apresenta alongada. Qtz - essa variedade apresenta cristais anedrais, recristalizados, com formação de neogrãos (Fig.3.2c). Com menor frequência, o quartzo ocorre incluso nos cristais de plagioclásio, descrevendo a textura mirmequítica.

O microclínio se apresenta com hábito subedral a anedral, inequigranular, com tamanho variando de 0,3 a $3,7 \mathrm{~mm}$. O contato com os demais minerais é serrilhado e sinuoso, com contorno irregular. Alguns cristais possuem maclamento do tipo albita- 

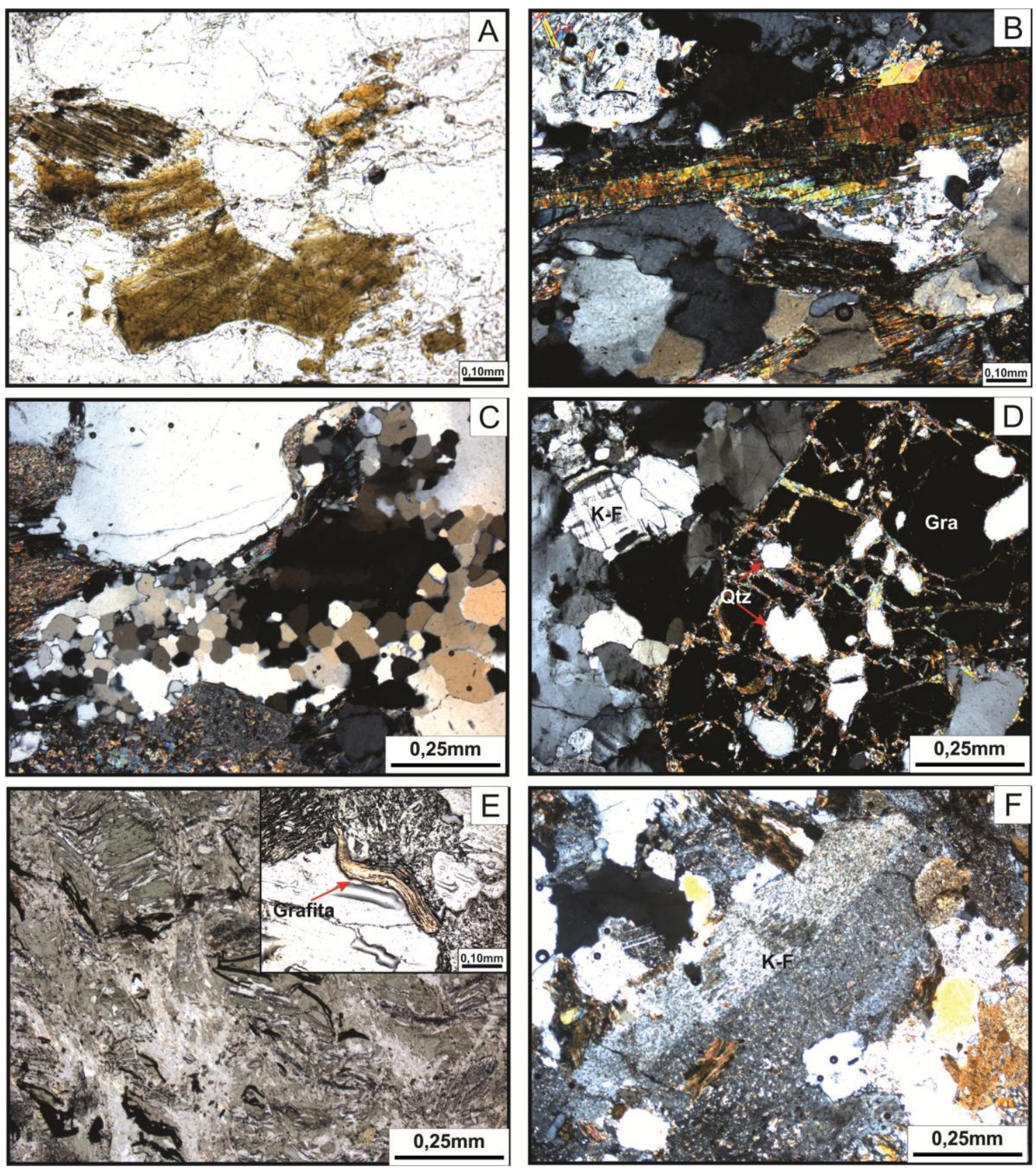

Figura 3.2: Fotomicrografia das rochas graníticas e dos xistos: (a) Biotita anedral sobnicóis paralelos que ocorre na fácies muscovita-biotita monzogranito; (b) Lamelas de muscovita magmática presente na fácies biotita-muscovita tonalito; (c) Quartzo microcristalino, com extinção ondulante com contato tríplice presente na fácies biotita-muscovita tonalito; (d) Fenocristal de granada, com inclusão de quartzo, presente no muscovita-biotita monzogranito com granada; (e) Aspecto textural do grafita-clorita xisto sobnicóis paralelos, com presença de clorita e com destaque para os cristais de grafita com hábito ondulado; (f) Cristal de ortoclásio presente na fácies biotita-muscovita monzogranito. 
periclina nítido (Fig.3.2f), porém outros apresentam maclamento difuso devido à pertitização. Alguns cristais têm forma alongada em virtude da deformação sofrida pela rocha. Localmente, apresentam inclusão de plagioclásio e quartzo. Os cristais de ortoclásio sãosubédricose equigranulares, com tamanho de aproximadamente 3,0 $\mathrm{mm}$. Os contatos são serrilhados com os demais minerais. Apresentam contorno irregular e maclas Carlsbad, com formação de micropertitas. Possuem inclusões de quartzo.

A biotita apresenta-se como cristais anedrais, equigranulares, contornos irregulares e contatos laterais sinuosos. Apresentam pleocroísmo variando de marromamarelado a marrom-pálido. Outros cristais possuem uma leve cor esverdeada. Altera paraepidotoe muscovita. Podem estar inclusos no plagioclásio e quartzo. Possuem fraca alteração para clorita. Os cristais de muscovita apresentam hábito subedral a anedral, equigranular, com tamanho de aproximadamente $0,5 \mathrm{~mm}$. Têm contatos reentrantes e sinuosos com os demais minerais e contorno irregular. Ocorrem alinhados e estirados, na maioria das vezes.

O zircão ocorre apenas localmente, como cristais euedrais submilimétricos, prismáticos e equigranulares finos, inclusos, geralmente, nos cristais de quartzo. A calcopirita e a pirita ocorrem geralmente associadas, com hábito anedral. Os fenocristais de granada desenvolvem cristais anedrais, e são equigranulares, com tamanho de $4 \mathrm{~mm}$, contatos reentrantes e contornos irregulares. Suas fraturas são preenchidas por lamelas de muscovita (Fig.3.2d). Apresentam inclusões de quartzo.

Os cristais de muscovita secundários apresentam hábito anedral, equigranular. Os cristais de epidoto ocorrem associadosà muscovita e ao plagioclásio, sendo o produto de alteração deste último, com hábito anedral a subedral. Os cristais de carbonato apresentam-se com hábito anedral. São produto de alteração do plagioclásio, ocorrendo apenas localmente. O rutilo ocorre apenas localmente, sendo resultado da alteração da biotita. Os cristais de zoisita ocorrem associados à muscovita secundária e ao plagioclásio. São anedrais. As lamelas de clorita são provenientes da alteração da biotita. São anedrais, ocorrendo apenas localmente. 


\subsubsection{TONALITO}

\section{Biotita-muscovita/Muscovita-biotita tonalito}

As fácies biotita-muscovita tonalito e muscovita-biotita tonalito,assim como as fácies biotita-muscovita/muscovita-biotita monzogranito,apresentam as mesmas características texturais e os mesmos minerais. A diferença ocorre na variação dos conteúdos modais da biotita e muscovita. Em decorrência desse fato, também se optou pordescrevê-las juntas.

Macroscopicamente, apresentam textura fanerítica, inequigranular, e possuem coloração cinza-esbranquiçado a cinza-escuro. Microscopicamente, apresentam textura granular hipidiomórfica, com aspecto anisotrópico, em que a foliação é descrita pelos cristais de biotita e muscovita. Apresentam-se como inequigranulares seriadas, com granulação variando de 0,1 a 5,0 mm. Apresentamintensidade moderada de deformação, afetando a muscovita primária e secundária, o plagioclásio e o quartzo, este último,com formação de cristais com extinção ondulante e recristalização desse mineral, com formação de cristais microcristalinos. Apresentam também uma forte alteração na rocha derivada da alteração do plagioclásio para sericita. O plagioclásio possui natureza altamente sódica (albitaAn $\mathrm{An}_{10-3 \%}$ ), determinada por meio de análise de química mineral em microssonda eletrônica. Também ocorremas texturas mirmequítica e granofírica. Com base na composição modal estimada das amostras estudadas, as duas fácies são constituídas por quartzo (31-37,5\%), albita(47,5-58\%) e microclínio (3-5\%), como minerais essenciais; biotita (1-2\%) e muscovita (1-5\%), como minerais varietais; pirita $(0,5 \%)$, calcopirita $(0,5 \%)$, grafita $(0,5 \%)$, titanita $(\operatorname{tr})$, zircão $(\operatorname{tr})$ emonazita $(\operatorname{tr})$, como minerais acessórios; epidoto (tr), muscovita (2-3\%), clorita (1\%) e zoisita (tr), como minerais secundários.

De acordo com a composição modal estimada das amostras estudadas, as duas fácies foram classificadas como tonalito, o que obedece à nomenclatura definida por Streckeisen (1976) e segue a denominação regional dessas rochas, atribuída por Botelho et al. (1999). Segundo Streckeisen (1976), os termos trondhjemito e plagiogranito podem ser aplicados para tonalito com menos de $10 \%$ de minerais máficos, como o descrito neste trabalho. Entretanto, optou-se por manter a nomenclatura descritiva básica. 
Os cristais de plagioclásio apresentam hábito subedral a anedral, são inequigranulares, com tamanho variando de 0,1 a $5 \mathrm{~mm}$, com contatos sub-retilíneos e, por vezes, reentrantes, com o quartzo, além de contorno irregular a regular. Apresentam maclas pouco nítidas devido à forte alteração sericítica, mas, quando visíveis, as maclas são do tipo albita. Ocorrem inclusões de quartzo e muscovita. Alguns cristais apresentam-se bordejados parcialmente pela muscovita secundária e possuem textura mirmequítica.

O quartzo se apresenta como cristais anedrais, com dimensões dos cristais variando de 0,1 a 3,5 $\mathrm{mm}$. Esse mineral ocorre em três variedades de acordo com o seu aspecto textural: $\mathrm{Qtz}_{1}$ - essa variedade apresenta cristais anedrais, com contatos serrilhados e reentrantes entre si e contorno irregular. Possui extinção ondulante, variando de moderada a forte, que, por vezes, evolui para bandas de deformação. Alguns cristais têm forma alongada, definindo uma orientação preferencial. Qtz $z_{2}$ essa variedade ocorre como cristais anedrais. Possuem contatos reentrantes com os cristais de plagioclásio e contornos irregulares. Apresenta extinção reta e ocorre apenas localmente. Qtz 3 - essa variedade apresenta cristais anedrais,recristalizados, com formação de neogrãos. Ocorre com menor frequência.

O microclínio apresenta-se com hábito subedral a anedral. O contato com os demais minerais é sub-retilíneo, com contorno irregular. É equigranular, com tamanho de aproximadamente $2,5 \mathrm{~mm}$. Alguns cristais possuem maclamento albita-periclina nítido, porém outrostêm um maclamento um pouco difuso.

A biotita apresenta hábito anedral. Alguns cristais, com forma de lamelas muito finas, são equigranulares. Alguns cristais de biotita estão alterados para rutilo (Fig.3.2a). Localmente, a biotita ocorre inclusa em cristais de quartzo. Apresenta pleocroísmo fraco, variando de castanho-amarelado a marrom-claro. Ocorre associada à muscovita secundária e ao epidoto.

As lamelas de muscovita primária são equigranulares, com tamanho variando de 0,1 a 1,5 mm. Algumas lamelas de muscovita são bem desenvolvidas, com hábito euedral, contato retilíneo e contorno regular. Outras apresentam-se como finas lamelas, com hábito variando de subedral a anedral, contatos sub-retilíneos a serrilhados e contorno irregular. Observa-se, ainda, pleocroísmo variando de verde-claro a amarelado. Outras lamelas apresentam pleocroísmo amarelo-avermelhado. 
Os cristais de pirita, por vezes, ocorrem associados à calcopirita. Ambos apresentam tamanho variando de 0,2 a $1 \mathrm{~mm}$ e apresentam hábito anedral. Os cristais de grafita são alongados, em forma de lamelas. Em algumas amostras, esses cristais são mais abundantes. Os cristais de zircão apresentam hábito subedral.

A muscovita secundária apresenta dimensões que permitem designá-la sericita. Ocorre, às vezes, bordejando ou alterando cristais de plagioclásio. A clorita tem hábito anedral, é equigranular e ocorre associada à muscovita secundária e à biotita. Os cristais de epidoto secundário possuem relevo alto e hábito subedral. Ocorrem associados ao plagioclásio. Os cristais de zoisita são anedrais, equigranulares e constituem-se em produto de alteração do plagioclásio, o que ocorre apenas em algumas rochas dessa fácies.

\subsubsection{PEGMATITOS}

Os pegmatitos foram observados apenas no garimpo Pelotas e ocorrem em contato com os granitos peraluminosos e a xistos, são concordantes com a foliação da rocha, mas, podem também serem discordantes.

Os pegmatitos encontrados no garimpo Pelotas não apresentam cassiterita em sua mineralogia, como documentado em outros garimpos da região. A sua mineralogia é composta por quartzo, K-feldspato, plagioclásio e muscovita.

Macroscopicamente, apresentam granulação média a grossa. As porções mais grossas são representadas pelo plagioclásio e principalmente pela muscovita com cerca de $1,0 \mathrm{~cm}$. Possuem cor branca, que muitas vezes causam podem ser confundido com o albitito. A muscovita ocorre como lamelas e está associada ao plagioclásio, devido ao grande conteúdo de plagioclásio nos pegmatitos desse garimpo. O quartzo e o Kfeldspato ocorrem em pouca quantidade, isso visto apenas macroscopicamente.

\subsubsection{ALBITITO}

Os albititos dos garimpos Boa Vista e Pelotas são bastante semelhantes. São constituídos de albita (90-91\%), quartzo (3-3,5\%), cassiterita (1-2\%), apatita (1-2\%), Kfeldspato (0-1\%), muscovita primária (2-4\%) e secundária (0-0,5\%). A porcentagem de alguns minerais também é semelhante, com exceção da apatita e da cassiterita, que são mais abundantes no garimpo Boa Vista. 
Os albititos são rochas holocristalinas, inequigranulares, isotrópicas, brancas, com disseminações evidentes de apatita verde e de cassiterita. Ao microscópio, a fração composta por cristais com tamanho variando de 0,2 a $1 \mathrm{~mm}$ é constituída principalmente por albita e, por vezes, muscovita secundária, enquanto a fração constituída por cristais variando de 1 a $6,5 \mathrm{~mm}$ compreende quartzo, cassiterita, apatita e muscovita primária.

Os albititos apresentam três tipos de albita, com hábito euedral a subedral e tamanho variando de 0,3 a 1,5 mm; a) Alb ${ }^{-}$albita com aspecto límpido, ou seja, sem alteração e com faces bem formadas, apresentando textura interpretada como de fluxo, com alinhamento das "ripas" de albita, com dimensões entre 1 a 1,5 mm; b) Alb ${ }_{2}$ - albita com tamanho de aproximadamente $0,3 \mathrm{~mm}$ que ocorre como ripas euedrais a subedrais apenas como inclusões nos cristaisde cassiterita e apatita. Os cristais de albita presentes nesses cristais descrevem a textura classificada como snowball (Schwartz 1992); c) $\mathrm{Alb}_{3}$ - albita com presença de alteração, sendo substituída levemente por sericita em suas bordas, com aspecto turvo. Ocorre geralmente com hábito subedral e com dimensões dos cristais entre 1 a 1,5 mm. Os três tipos texturais de albita são interpretados como de origem magmática, com base em critérios texturais.

O quartzo também foi agrupado em variedades diferentes, de acordo com seus aspectos texturais. Apresenta hábito subedral a anedral, com tamanho variando de 0,2 a 6,5mm. As três variedades são: a) $\mathrm{Qtz}_{1}$ - os cristais com aspectos límpidos, sem inclusões, com tamanho dos cristais entre 1 a 1,5 mm, extinção reta, primários; b) Qtz 2 os cristais possuem extinção ondulante variando de moderada a forte que, por vezes, evolui para bandas de deformação. As dimensões dos cristais variam entre 1 e 6,5 mm (Fig. 3.4a); c) Qtz $_{3}$ - cristais com tamanho variando de 0,2 a $0,5 \mathrm{~mm}$, recristalizados, com formação de subgrãos que, por vezes, ocorrem bordejando cristais maiores de quartzo descrevendo a textura núcleo-manto. Em algumas amostras, apresentam-se ainda como aglomerado de finos cristais alinhados em forma de veios com bordas interlobadas. Os dois últimos tipos de quartzo apresentam aspecto de reequilíbrio metamórfico.

Duas gerações de muscovita foram identificadas: a) muscovita primária, com lamelas bem desenvolvidas, de aproximadamente 4,0 mm (Fig.3.3d), com contatos retilíneos e subretilíneos entre si e com os demais minerais. A maioria apresenta aspecto 
límpido. Alguns cristais apresentam-se corroídas em suas bordas; b) muscovita secundária; por vezes, ocorre como um agregado de muscovita.

A cassiterita possui hábito euedral a subedral, com tamanho variando de 0,5 a $5,0 \mathrm{~mm}$, frequentemente geminados, pleocroismo variando de marrom avermelhado até marrom amarelado (Fig. 3.4e,f). É comum conter inclusões de albita do tipo 2 (Fig.3.3c), quartzo do tipo 3 e, mais raramente, muscovita. Alguns cristais apresentam bordas corroídas.

A apatita apresenta hábito subedral, com tamanho variando de 1,0 a 5,5 mm. Ocorre como mineral intersticial na maioria das vezes. Em geral apresenta inclusões de ripas de albita $\left(\mathrm{alb}_{2}\right)$ dispostas aleatoriamente, sendo que em alguns cristais a albita ocorre disposta paralelamente à borda da apatita (Fig.3.3f).

O microclínio é subedral a anedral, com tamanho variando de 0,5 a 1,5 $\mathrm{mm}$. O contato com os demais minerais é serrilhado e sinuoso. Possui maclamento albitapericlina. Localmente apresenta inclusão de plagioclásio e quartzo. 

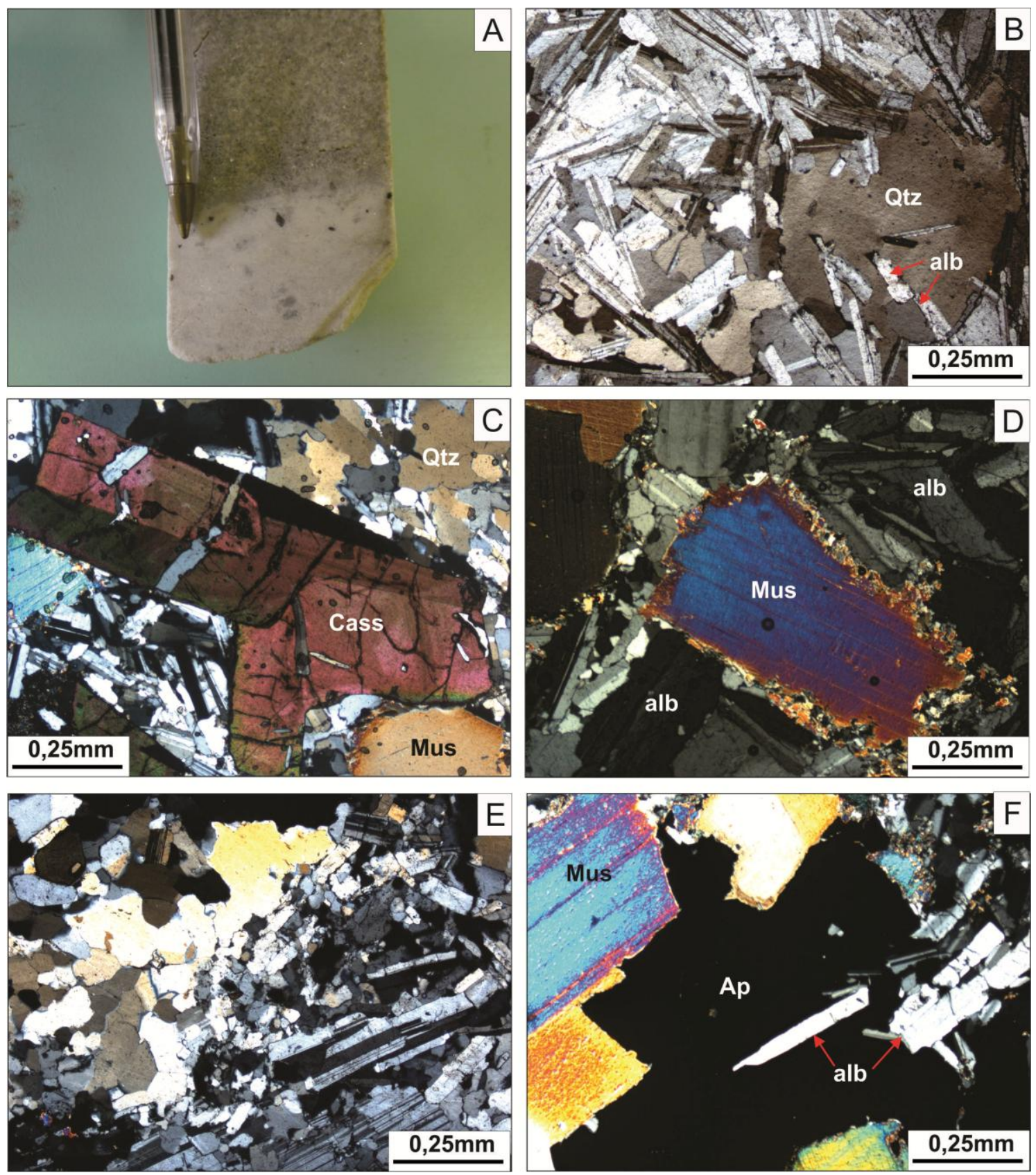

Figura 3.3: Aspectos mineralógicos e texturais dos albititos dos garimpos Boa Vista e Pelotas. a) Aspecto macroscópico dos albititos mostrando contato abrupto com o granito; b) Cristais de quartzo com inclusões de "ripas" de albita; c) Fenocristal euedral de cassiterita; d) Cristal de muscovita magmática com bordas corroídas; e) Contato entre o albitito e o biotita-muscovita monzogranito; (f) Apatita intersticial com inclusão de albita e contatos reentrantes com a muscovita magmática. 

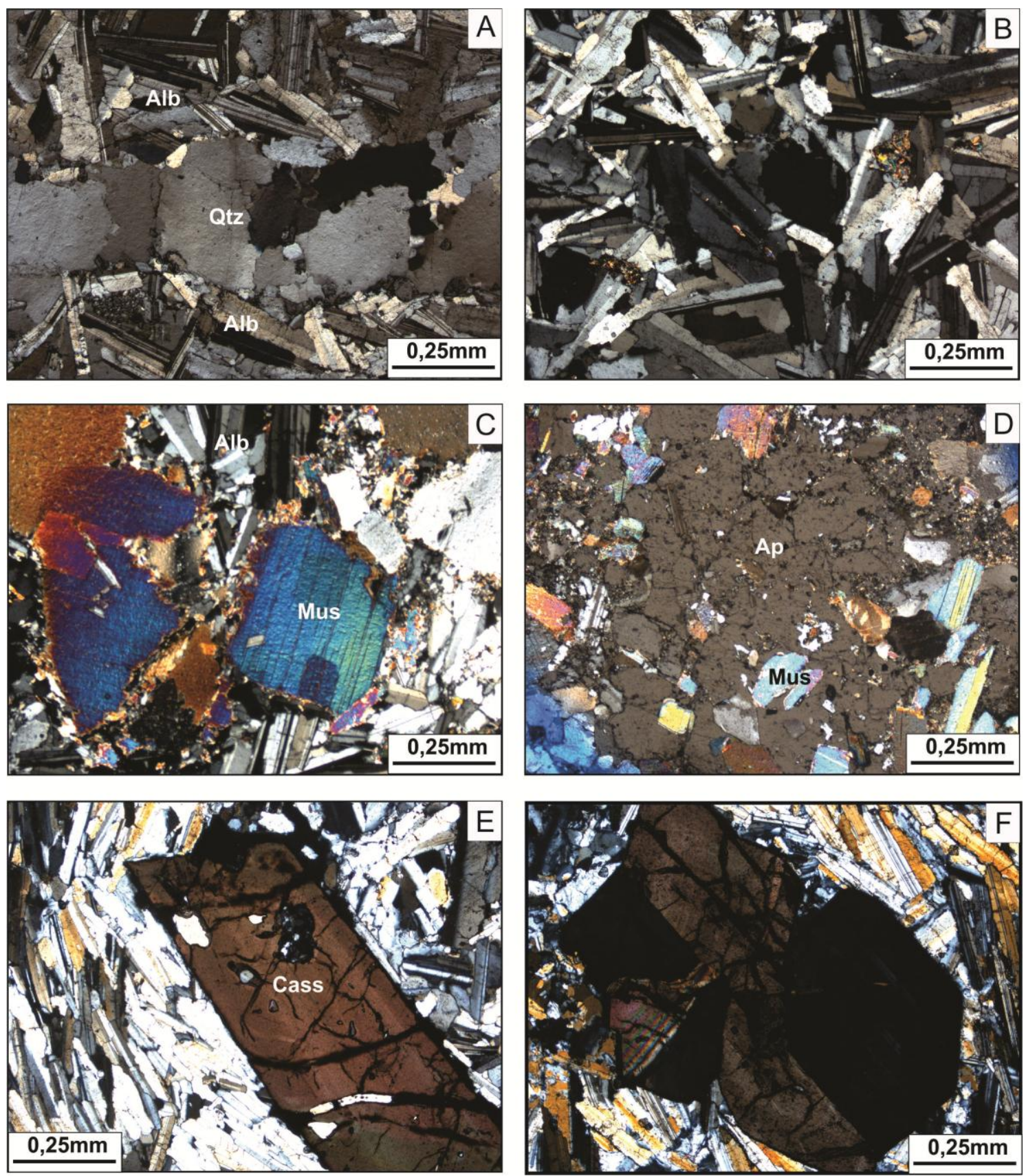

Figura 3.4: Aspectos mineralógicos e texturais dos albititos dos garimpos Boa Vista e Pelotas. a) Vênula de quartzo com extinção ondulante e contato serrilhado cortando os cristais de albita; b) Cristais de albita sem orientação preferencial; c) Cristais de muscovita com hábito subedral apresentando borda de reação; d) Cristal de apatita com hábito anedral com inclusões de muscovita; e, f) Cassiterita geminada bordejada por ripas de albita. 


\subsubsection{DISCUSSÃO SOBRE AS CARACTERÍSTICAS TEXTURAIS DOS ALBITITOS}

Os albititos estudados são caracterizados por apresentar texturas magmáticas típicas, como textura snowball e de fluxo, com alinhamento das ripas de albita na matriz. A textura de fluxo é marcante e ressaltada pelo alinhamento dos cristais de albita sob a forma de "ripas", que, ocasionalmente, mostram arranjo paralelo, desenvolvendo uma textura do tipo cumulática (Fig.3.6e,f). As "ripas" de albita apresentam faces bem formadas, com contatos retilíneos a subretilineos entre si e com aspecto límpido na maioria das vezes, sem evidência de alteração ou de deformação.

Outra textura bastante marcante nos albititos é representada pela textura snowball. $O$ termo textura snowball se refere a inclusões poiquiliticas de "ripas"de albita euedral a subedral em cristais desenvolvidos, geralmente em granitos de metais raros (Zhu et al. 2001, Lenharo et al. 2003, Mohamed 2012). Tal textura nas rochas estudadas neste trabalho é exibida mais comumente pelos cristais mais desenvolvidos, sendo definida pela inclusão de "ripas" de albita dispostas paralelamente às bordas dos cristais de cassiterita e apatita.

Os cristais de cassiterita apresentam na sua maioria a textura snowball, presente principalmente nos cristais mais desenvolvidos. As "ripas" de albita ocorrem como inclusões no núcleo dos cristais de cassiterita (Fig.3.6a,b), muitas vezes não apresentando a rotação completa do cristal hospedeiro, como é caracteristicamente observado em cristais relatados na literatura (Schwartz 1992, Yin et al. 1995, Zhu et al. 2001, Müller et al. 2002, Lenharo et al. 2003, Breiter et al. 2005).

Os cristais de apatita também apresentam na sua maioria a textura snowball, que ocorre de duas maneiras: a primeira apresenta a textura típica de snowball, com "ripas" de albita muito finas, dispostas paralelamente às bordas do cristal; e na segunda, as inclusões de albita ocorrem por todo cristal e não apenas em suas bordas (Fig.3.6c,d).

Nos cristais de quartzo, a textura snowball não ocorre com tanta freqüência. Os cristais de albita que ocorrem como inclusões são maiores do que as inclusões que ocorrem em outros cristais, mas ainda pode ser observada a disposição desses cristais paralelamente à borda dos cristais de quartzo.

Segundo Zhu et al. (2001), a formação da textura snowball pode ser interpretada como cristalização precoce da albita a partir do fundido, sendo seguida pelos outros minerais. As "ripas" de albita e seus agregados geralmente não contêm outros minerais 
constituintes de rochas e acessórios, mas são freqüentemente aprisionadas em apatita e cassiterita como inclusões poiquilíticas, em muitos casos ocupando o núcleo do cristal e as zonas de crescimento dos cristais hospedeiros, como se pode observar no desenho esquemático da textura snowball (Fig.3.5). Os fenocristais também podem ter cristalizado a partir do fundido e englobado os cristais de albita, coexistindo durante o crescimento. Estas características texturais sugerem que a albita é de origem magmática e não hidrotermal (Zhu et al. 2001).
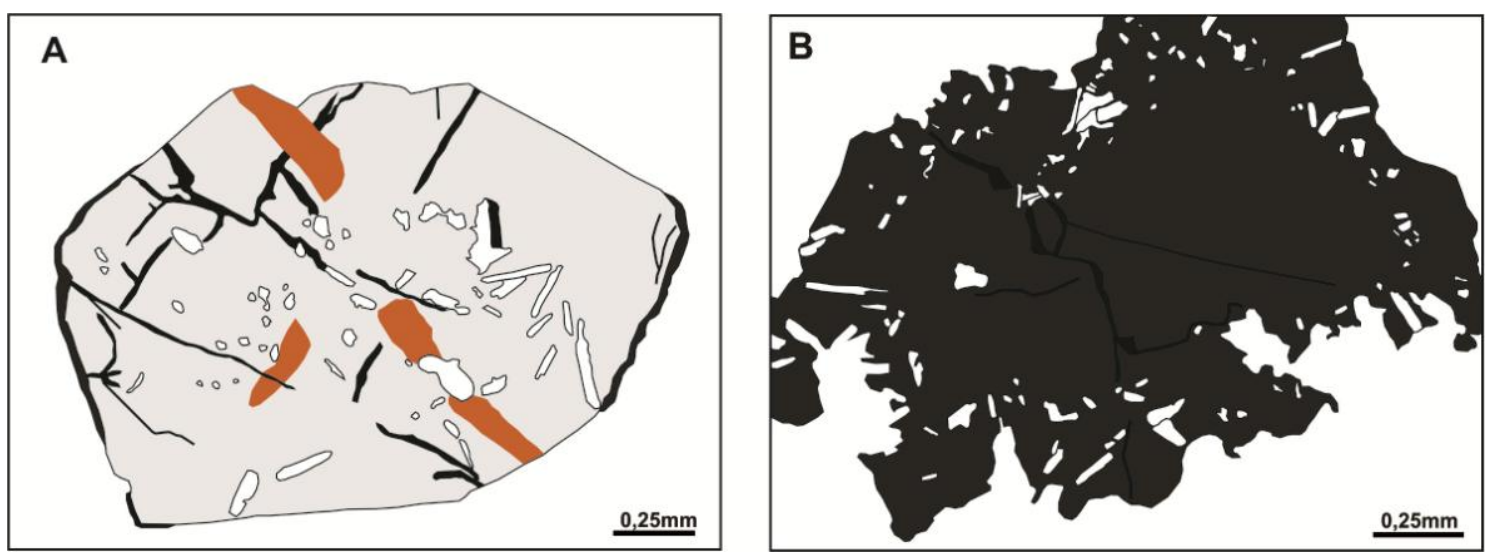

Figura 3.5: Desenho esquemático da textura snowball que ocorre nos albititos; a) "ripas" de albita concentradas no núcleo do cristal de cassiterita; b) "ripas" de albita ao longo das bordas do cristal de apatita.

Yin et al. (1995) também observaram a textura snowball em granitos evoluídos na Província Jiangxi, sul da China. Segundo suas observações,as "ripas"de albita geralmente com tamanho menor que $0,5 \mathrm{~mm}$ ocupam claramente zonas de crescimento dentro dos cristais hospedeiros e podem se estender a partir da zona central até a borda, embora alguns fenocristais sejam relativamente livres de inclusão nos núcleos. De acordo com os autores, a relação reflete a cristalização simultânea dos cristais hospedeiros com a albita, a partir de um magma granítico residual.

As duas interpretações citadas acima sobre a formação da textura snowball são citadas por vários autores. De acordo com alguns, a textura snowball pode ser formada por cristalização simultânea entre a albita e os cristais hospedeiros (Schwartz 1992, Yin et al. 1995, Lenharo et al. 2003, Saleh et al. 2007), enquanto outros autores defendem que houve cristalização precoce de albita, que foi posteriormente englobada pelos outros minerais (Zhu et. al. 2001, Mohamed 2012). Ambas interpretações podem ser consideradas nos albititos estudados neste trabalho. 

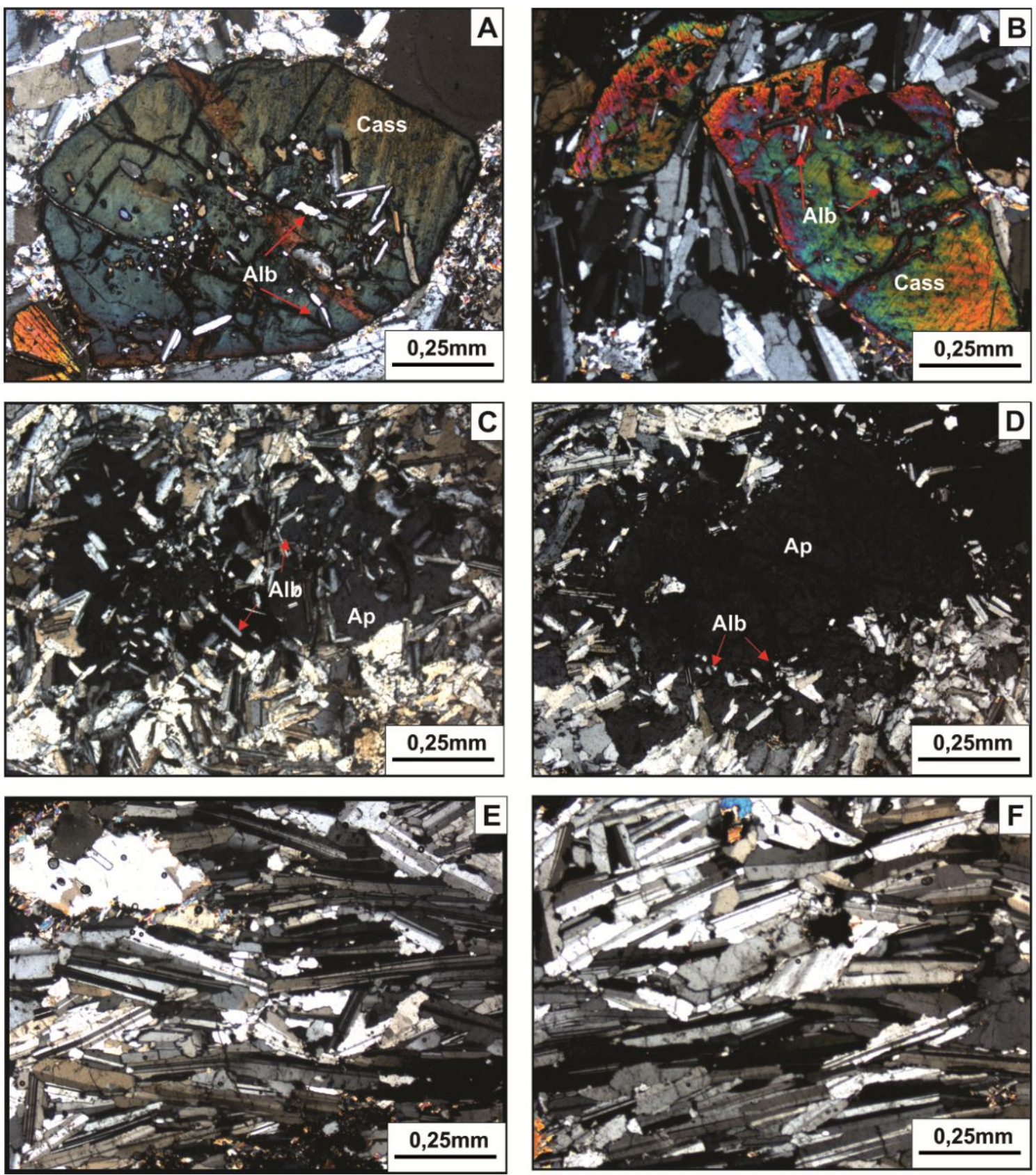

Figura 3.6: Características texturais dos albititos (textura snowball); a, b) Cassiterita com inclusões de ripas de albita no núcleo; c, d) Inclusões de ripas de albita por todo o cristal de apatita e dispostas paralelamente às bordas da apatita, respectivamente; e,f) Alinhamento de ripas de albita configurando textura interpretada como cumulática. 


\subsection{LITOGEOQUÍMICA}

Conforme a metodologia descrita no item 1.4.5, foram selecionadas 21 amostras para análise de químicade rocha total. As análises geoquímicas presentes neste trabalho têm como finalidade caracterizar os xistos, monzogranitos, tonalitos e albititos dos garimpos Pelotas e Boa Vista. Apenas as fácies muscovita-biotita tonalito e muscovitabiotita monzogranito não foram caracterizados geoquímicamente. Os dados encontramse na tabela 3.2. Foram confeccionadosdiagramas de correlação com o objetivo de observar as principais características químicas das rochas analisadas.

\subsubsection{ELEMENTOS MAIORES E TRAÇOS}

Os monzogranitos apresentam valores de $\mathrm{SiO}_{2}$ entre 70,94 e 75,89\%. Os tonalitos apresentam valores entre 74,89 e 74,89\%. Essas rochas são classificadas como rochas peraluminosas (ISA= 1,1 a 1,8). Os xistos apresentam teor de $\mathrm{SiO}_{2}$ entre 49,83 e 50,29\%. Já os albititos apresentam teores de $\mathrm{SiO}_{2}$ entre 70,48 e 75,86\% e são classificados como rochas metaluminosas a peraluminosas (ISA=0,8 a 1,3), de acordo com o diagrama de Shand (1943) (Fig. 3.7).

No diagrama $\mathrm{SiO}_{2}$ vs. ISA (índice de saturação alumina), observou-se que as amostras de albititos foram divididas em dois grupos com relação ao ISA. Os albititos com mais baixo teor de $\mathrm{SiO}_{2}$ apresentam ISA variando de 0,8 a 0,95 e os albititos com mais alto teor de $\mathrm{SiO}_{2}$ apresentam ISA variando de 1,1 a 1,25, o que pode ser explicado pela maior quantidade de muscovita em algumas amostras. Já os monzogranitos e tonalitos apresentaram ISA $>1.0$, revelando seu caráter fortemente peraluminoso, independentemente do teor de $\mathrm{SiO}_{2}$. 


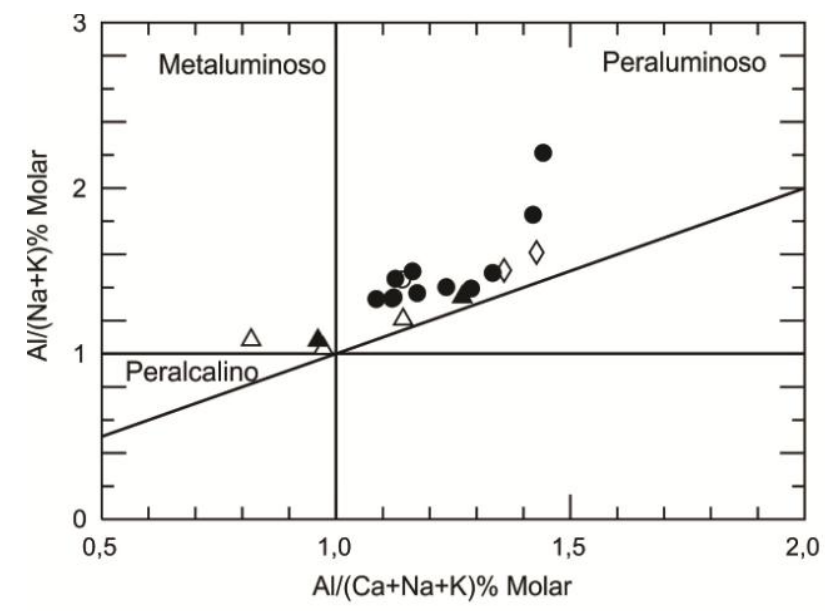

- Muscovita-biotita monzogranito

o Biotita-muscovita monzogranito

$\checkmark$ Biotita-muscovita tonalito

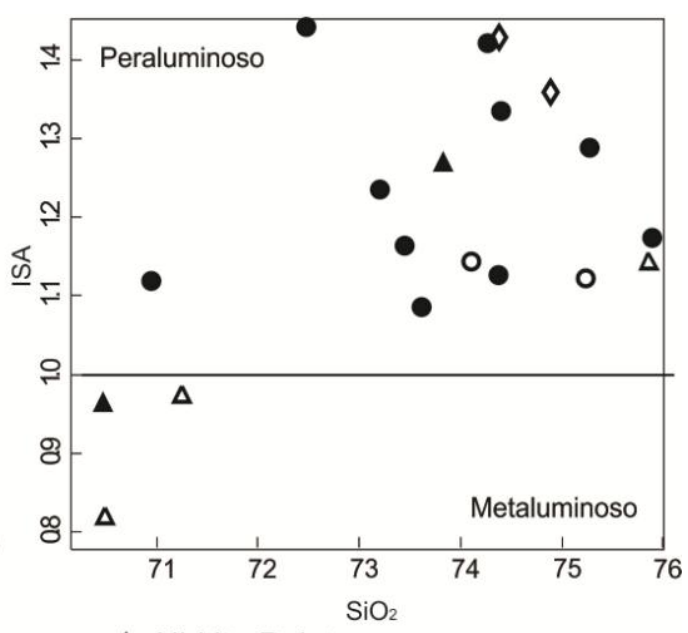

$\triangle$ Albitito Pelotas

$\Delta$ Albitito Boa Vista

Figura 3.7: Diagrama de Shand (1943), mostrando o caráter peraluminoso dos monzogranitos e tonalitos e o caráter metaluminoso a peraluminoso dos albititos dos garimpos Pelotas e Boa Vista, e o diagrama ISA vs. $\mathrm{SiO}_{2}$, evidenciado o caráter peraluminoso com o aumento da sílica.

Os albititos apresentam enriquecimento em teores de $\mathrm{Na}_{2} \mathrm{O}, \mathrm{Al}_{2} \mathrm{O}_{3}$ e $\mathrm{P}_{2} \mathrm{O}_{5}$, valores moderados de $\mathrm{CaO}$ e empobrecimento em $\mathrm{K}_{2} \mathrm{O}, \mathrm{TiO}_{2}, \mathrm{Fe}_{2} \mathrm{O}_{3}$ e $\mathrm{MgO}$. A relação entre $\mathrm{Al}_{2} \mathrm{O}_{3}$ vs. $\mathrm{SiO}_{2}$ e de $\mathrm{Na}_{2} \mathrm{O}$ vs. $\mathrm{SiO}_{2}$ mostra que, tanto nos albititos do garimpo Boa Vista quanto nos albititos do garimpo Pelotas, ocorre diminuição gradual de $\mathrm{Al}$ e $\mathrm{Na}$ com o aumento de $\mathrm{SiO}_{2}$. O comportamento do $\mathrm{P}_{2} \mathrm{O}_{5}$ e do $\mathrm{CaO}$ também não se diferencia dos anteriores, ocorrendo diminuição de $\mathrm{P}_{2} \mathrm{O}_{5}$ e $\mathrm{CaO}$ com o aumento do conteúdo de $\mathrm{SiO}_{2}$.

A relação entre $\mathrm{K}_{2} \mathrm{O}$ vs. $\mathrm{SiO}_{2}$ apresenta comportamento diferente: há um pequeno aumento de $\mathrm{K}_{2} \mathrm{O}$ com o aumento de $\mathrm{SiO}_{2}$. Isso pode estar relacionado ao pequeno conteúdo de K-feldspato em algumas amostras, e esse conteúdo não ultrapassa 1\%. $\mathrm{O} \mathrm{TiO}_{2}, \mathrm{Fe}_{2} \mathrm{O}_{3}$ e o $\mathrm{MgO}$ apresentam o mesmo comportamento, com os baixos valores nos albititos, sendo que, em algumas amostras, esses elementos estiveram abaixo do limite de detecção. Isso é compatível com os aspectos petrográficos dessa rocha, pois são raros os minerais que contenham tais elementos.

Elementos como Ba e Th apresentam os mesmos comportamentos nos albititos. O baixo teor nesses elementos é explicado pela ausência de minerais em sua constituição.

No diagrama $\mathrm{Sr}$ vs. $\mathrm{SiO}_{2}$, foi observada correlação negativa, ocorrendo diminuição de $\mathrm{Sr}$ com o aumento de $\mathrm{SiO}_{2}$. Isso indica que esse elemento teve comportamento compatível com a fase sólida, apresentando um empobrecimento nesse 
elemento, com o aumento de $\mathrm{SiO}_{2}$. Já o $\mathrm{Rb}$ teve enriquecimento nos albititos com mais alto teor de $\mathrm{SiO}_{2}$.

O Sn, assim como o $\mathrm{Ta}$ eo $\mathrm{Nb}$, comporta-se como elemento incompatível, enriquecendo-se no líquido residual com o aumento de $\mathrm{SiO}_{2}$. A única exceção foi a amostra FPS-7-5-19,45, de albitito, que teve empobrecimento em $\mathrm{Nb}$ e $\mathrm{Ta}$. O $\mathrm{Zr}$ apresenta comportamento incompatível, sendo que os teores desses elementos são mais baixos nos albititos com mais baixo teor de $\mathrm{SiO}_{2}$. Isso sugere enriquecimento de $\mathrm{Zr}$ na fase líquida durante o processo de diferenciação. 
Rochas albitizadas e albititos relacionados a mineralizações de estanho da Província Estanífera de Goiás: caracterização petrológica e gênese.

Tabela 3.2: Resultados da análise química de rocha total nas amostras da área de estudo. Abreviações:

BMT (biotita-muscovita tonalito).

\begin{tabular}{|c|c|c|c|c|c|c|c|c|c|}
\hline GARIMPO & \multicolumn{2}{|c|}{ BOA VISTA } & \multicolumn{7}{|c|}{ PELOTAS } \\
\hline \multirow{2}{*}{ Rocha } & \multirow{2}{*}{\multicolumn{2}{|c|}{ Albitito }} & \multirow{2}{*}{\multicolumn{3}{|c|}{ Albitito }} & \multirow{2}{*}{\multicolumn{2}{|c|}{$\begin{array}{c}\text { Tonalitos } \\
\text { BMT } \\
\end{array}$}} & \multirow{2}{*}{\multicolumn{2}{|c|}{ Xisto }} \\
\hline & & & & & & & & & \\
\hline Amostra & PA-1B & PA-01-DII & $\begin{array}{c}\text { FPS-5-8- } \\
30,00\end{array}$ & $\begin{array}{c}\text { FPS-7-5- } \\
19,45\end{array}$ & FPS-8-8-34,75 & $\begin{array}{l}\text { FPS-5-7- } \\
27,57\end{array}$ & FPS-5-7-28,05 & $\begin{array}{c}\text { FPS-5-8-32,17- } \\
32\end{array}$ & $\begin{array}{c}\text { FPS-5-10- } \\
42,80\end{array}$ \\
\hline \multicolumn{10}{|l|}{$\%$} \\
\hline $\mathrm{SiO}_{2}$ & 78,83 & 70,48 & 71,25 & 75,86 & 70,49 & 74,38 & 74,89 & 49,83 & 50,29 \\
\hline $\mathrm{TiO} 2$ & $<0.01$ & $<0.01$ & $<0.01$ & 0,04 & $<0.01$ & 0,02 & 0,02 & 0,8 & 1,16 \\
\hline $\mathrm{Al} 2 \mathrm{O} 3$ & 15,81 & 17,1 & 16,83 & 14,25 & 15,03 & 16,25 & 15,47 & 23,58 & 20,66 \\
\hline $\mathrm{Fe} 2 \mathrm{O} 3$ & 0,18 & 0,1 & 0,15 & 0,27 & 0,22 & 0,36 & 0,35 & 9,19 & 12,05 \\
\hline $\mathrm{MnO}$ & 0,01 & 0,01 & 0,06 & 0,01 & 0,05 & $<0.01$ & $<0.01$ & 0,27 & 0,18 \\
\hline $\mathrm{MgO}$ & $<0.01$ & $<0.01$ & $<0.01$ & 0,06 & 0,04 & 0,08 & 0,1 & 2,21 & 3,21 \\
\hline $\mathrm{CaO}$ & 0,37 & 1,07 & 0,53 & 0,36 & 2,46 & 0,71 & 0,6 & 2,35 & 1,46 \\
\hline $\mathrm{Na} 2 \mathrm{O}$ & 6,28 & 9,59 & 9,86 & 6,6 & 8,08 & 4,79 & 5,12 & 2,49 & 0,66 \\
\hline $\mathrm{K} 2 \mathrm{O}$ & 1,34 & 0,06 & 0,1 & 0,88 & 0,54 & 2,04 & 1,73 & 4,55 & 4,63 \\
\hline $\mathrm{P} 2 \mathrm{O} 5$ & 0,3 & 0,78 & 0,43 & 0,26 & 1,82 & 0,07 & 0,06 & 0,11 & 0,09 \\
\hline P.F & 1 & 0,7 & 0,6 & 0,9 & 0,8 & 1,2 & 1,5 & 4,3 & 5,3 \\
\hline TOTAL & 99,15 & 99,93 & 99,83 & 99,51 & 99,55 & 99,85 & 99,87 & 99,72 & 99,7 \\
\hline \multicolumn{10}{|l|}{$\mathrm{ppb}$} \\
\hline $\mathrm{Au}$ & $<0.5$ & $<0.5$ & 0,5 & $<0.5$ & 0,6 & 1,1 & 0,8 & 0,7 & 0,5 \\
\hline \multicolumn{10}{|l|}{$\mathrm{ppm}$} \\
\hline $\mathrm{Be}$ & 228 & 31 & 148 & 4 & 4 & 4 & $<1$ & 14 & 12 \\
\hline $\mathrm{Rb}$ & 374,2 & 1,5 & 2,5 & 282 & 33,4 & 63,8 & 57,1 & 219 & 202,6 \\
\hline Cs & 126,5 & 0,2 & 2,8 & 84,6 & 1,9 & 10,4 & 9,5 & 28,7 & 8,7 \\
\hline $\mathrm{Ba}$ & 13 & 3 & 7 & 49 & 31 & 602 & 526 & 701 & 826 \\
\hline $\mathrm{Sr}$ & 49,6 & 115,1 & 75,3 & 33,4 & 138,5 & 289,7 & 265,2 & 378,6 & 116,1 \\
\hline $\mathrm{Ga}$ & 23,8 & 15,7 & 13,4 & 15,4 & 14 & 13,3 & 110,6 & 28,7 & 31 \\
\hline $\mathrm{V}$ & 24 & 21 & 27 & 21 & 23 & 32 & 33 & 146 & 198 \\
\hline Sn & 5143 & 8 & 398 & 3218 & 2851 & 11 & 11 & 4 & 4 \\
\hline W & 2,7 & $<0.5$ & $<0.5$ & 2 & 0,9 & 1,5 & 1,4 & 4,1 & 0,6 \\
\hline $\mathrm{Ta}$ & 148,6 & 1,7 & 18,7 & 24,2 & 111,3 & 0,1 & $<0.1$ & 0,9 & 1,5 \\
\hline $\mathrm{Nb}$ & 159,8 & 1,3 & 12,9 & 12 & 72,2 & 0,6 & 0,7 & 11,9 & 18,8 \\
\hline Th & $<0.2$ & 0,5 & $<0.2$ & 0,9 & 0,2 & 2,8 & 0,4 & 17,5 & 18,1 \\
\hline $\mathrm{U}$ & 2,3 & 2,8 & 0,8 & 1,5 & 6,2 & $<0.1$ & 0,2 & 4,3 & 5,4 \\
\hline $\mathrm{Zr}$ & 25,4 & 15,5 & 21,5 & 36,3 & 16,1 & 1,2 & 5,5 & 189,1 & 289,5 \\
\hline $\mathrm{Hf}$ & 3,5 & 1,4 & 2,9 & 3,3 & 2,6 & $<0.1$ & $<0.1$ & 4,6 & 7,8 \\
\hline $\bar{Y}$ & 0,4 & 2 & 0,1 & 1,6 & 4 & 0,4 & 0,9 & 34,9 & 38,7 \\
\hline $\mathrm{Sc}$ & $<1$ & $<1$ & $<1$ & $<1$ & $<1$ & $<1$ & $<1$ & 23 & 28 \\
\hline $\mathrm{La}$ & 0,4 & 0,9 & 0,2 & 2,7 & 2,3 & 3,4 & 2,7 & 57,9 & 70,9 \\
\hline $\mathrm{Ce}$ & 0,1 & 1,7 & 0,2 & 4,3 & 4,5 & 4,9 & 5,3 & 117,7 & 147,7 \\
\hline $\mathrm{Pr}$ & $<0.02$ & 0,16 & $<0.02$ & 0,44 & 0,46 & 0,52 & 0,52 & 12,96 & 15,1 \\
\hline $\mathrm{Nd}$ & $<0.3$ & 1,2 & $<0.3$ & 1,6 & 0,9 & 1,2 & 1,6 & 46,4 & 50,1 \\
\hline $\mathrm{Sm}$ & $<0.05$ & 0,21 & $<0.05$ & 0,26 & 0,69 & 0,19 & 0,24 & 9,03 & 9,87 \\
\hline $\mathrm{Eu}$ & $<0.02$ & 0,12 & $<0.02$ & 0,09 & 0,27 & 0,9 & 0,87 & 1,72 & 1,58 \\
\hline $\mathrm{Gd}$ & $<0.02$ & 0,22 & $<0.05$ & 0,3 & 0,97 & 0,2 & 0,32 & 7,43 & 7,63 \\
\hline $\mathrm{Tb}$ & 0,01 & 0,06 & $<0.01$ & 0,05 & 0,28 & 0,03 & 0,03 & 1,11 & 1,22 \\
\hline Dy & $<0.05$ & 0,19 & $<0.05$ & 0,3 & 1,11 & 0,09 & 0,11 & 7,08 & 7,57 \\
\hline Ho & $<0.02$ & $<0.02$ & $<0.02$ & 0,05 & 0,09 & 0,03 & 0,02 & 1,37 & 1,47 \\
\hline $\mathrm{Er}$ & $<0.03$ & 0,05 & $<0.03$ & 0,06 & 0,07 & $<0.03$ & $<0.03$ & 4,09 & 4,14 \\
\hline $\mathrm{Tm}$ & $<0.01$ & 0,02 & $<0.01$ & $<0.01$ & 0,01 & $<0.01$ & $<0.01$ & 0,61 & 0,65 \\
\hline $\mathrm{Yb}$ & $<0.05$ & 0,07 & $<0.05$ & $<0.05$ & $<0.05$ & $<0.05$ & 0,09 & 3,96 & 4,41 \\
\hline $\mathrm{Lu}$ & 0,01 & $<0.01$ & $<0.01$ & $<0.01$ & $<0.01$ & 0,02 & 0,02 & 0,59 & 0,63 \\
\hline $\mathrm{Ni}$ & 0,2 & 0,1 & 0,5 & $<0.1$ & $<0.1$ & 0,2 & 0,3 & 42,1 & 73,3 \\
\hline $\mathrm{Cr}$ & $<20$ & $<20$ & $<20$ & $<20$ & $<20$ & $<20$ & $<20$ & 116,28 & 171 \\
\hline Co & $<0.2$ & $<0.2$ & $<0.2$ & 0,4 & 0,3 & 0,7 & 0,5 & 21,6 & 35,7 \\
\hline $\mathrm{Cu}$ & 0,3 & 1,3 & 1,7 & 0,5 & 1,2 & 1,2 & 1,4 & 73,2 & 91,7 \\
\hline $\mathrm{Cd}$ & $<0.1$ & $<0.1$ & $<0.1$ & 0,1 & 2,1 & $<0.1$ & $<0.1$ & $<0.1$ & 0,2 \\
\hline $\mathrm{Zn}$ & 6 & 10 & 3 & 4 & 14 & $<1$ & $<1$ & 97 & 180 \\
\hline $\mathrm{Pb}$ & 0,8 & 4 & 0,6 & 3,8 & 8,5 & 22,7 & 25,8 & 5,5 & 83,6 \\
\hline Mo & $<0.1$ & $<0.1$ & 0,1 & $<0.1$ & $<0.1$ & $<0.1$ & $<0.1$ & 0,7 & 1,4 \\
\hline $\mathrm{Ag}$ & $<0.1$ & $<0.1$ & $<0.1$ & $<0.1$ & $<0.1$ & $<0.1$ & $<0.1$ & $<0.1$ & 0,4 \\
\hline As & $<0.5$ & $<0.5$ & $<0.5$ & $<0.5$ & $<0.5$ & 0,6 & $<0.5$ & 3 & $<0.5$ \\
\hline $\mathrm{Sb}$ & $<0.1$ & $<0.1$ & $<0.1$ & $<0.1$ & $<0.1$ & $<0.1$ & $<0.01$ & $<0.1$ & $<0.1$ \\
\hline $\mathrm{Bi}$ & $<0.1$ & $<0.1$ & $<0.1$ & $<0.1$ & $<0.1$ & 1,9 & 0,8 & 0,1 & 1,9 \\
\hline $\mathrm{Se}$ & $<0.5$ & $<0.5$ & $<0.5$ & $<0.5$ & $<0.5$ & $<0.5$ & $<0.5$ & $<0.5$ & $<0.5$ \\
\hline $\mathrm{Hg}$ & $<0.01$ & 0,03 & $<0.01$ & $<0.01$ & $<0.01$ & $<0.01$ & $<0.01$ & $<0.01$ & $<0.01$ \\
\hline $\mathrm{Tl}$ & 0,1 & $<0.1$ & $<0.1$ & 0,2 & $<0.1$ & $<0.1$ & $<0.1$ & 0,2 & 0,2 \\
\hline
\end{tabular}


Rochas albitizadas e albititos relacionados a mineralizações de estanho da Província Estanífera de Goiás: caracterização petrológica e gênese.

Tabela 3.2: Continuação. Abreviações: BMG (biotita-muscovita monzogranito); MBG (muscovita-biotita monzogranito).

\begin{tabular}{|c|c|c|c|c|c|c|c|c|c|c|c|}
\hline \multirow[t]{3}{*}{ GARIMPO } & \multicolumn{11}{|c|}{ PELOTAS } \\
\hline & \multicolumn{11}{|c|}{ Monzogranito } \\
\hline & \multicolumn{9}{|c|}{ BMM } & \multicolumn{2}{|c|}{ MBM } \\
\hline Amostra (\%) & $\begin{array}{l}\text { FPS-4- } \\
7-26,35\end{array}$ & $\begin{array}{c}\text { FPS-4-7- } \\
29,10\end{array}$ & $\begin{array}{l}\text { FPS-4-7- } \\
35,25-58\end{array}$ & $\begin{array}{l}\text { FPS-6-6- } \\
26,33-61\end{array}$ & $\begin{array}{c}\text { FPS-7-5- } \\
20,55\end{array}$ & $\begin{array}{c}\text { FPS-7-7- } \\
\mathbf{3 0 , 7 0}\end{array}$ & $\begin{array}{c}\text { FPS-6-6- } \\
23,68\end{array}$ & $\begin{array}{c}\text { FPS-8-10- } \\
43,60\end{array}$ & $\begin{array}{c}\text { FPS-8-6- } \\
25,90\end{array}$ & $\begin{array}{c}\text { FPS-2-3- } \\
9,15\end{array}$ & $\begin{array}{c}\text { FPS-4-5- } \\
19,25\end{array}$ \\
\hline$\overline{\mathrm{SiO}_{2}}$ & 74,26 & 75,27 & 73,62 & 74,4 & 73,21 & 74,37 & 75,89 & 73,45 & 70,94 & 75,24 & 74,12 \\
\hline $\mathrm{TiO} 2$ & 0,02 & 0,14 & 0,12 & 0,16 & 0,07 & 0,13 & 0,14 & 0,15 & 0,3 & 0,05 & 0,11 \\
\hline $\mathrm{Al} 2 \mathrm{O} 3$ & 14,65 & 14,32 & 14,54 & 14,86 & 15,7 & 14,25 & 13,46 & 14,62 & 14,42 & 14,13 & 14,42 \\
\hline $\mathrm{Fe} 2 \mathrm{O} 3$ & 0,46 & 0,79 & 1,15 & 1,21 & 0,83 & 1,21 & 1,09 & 1,51 & 2,45 & 0,62 & 1,22 \\
\hline $\mathrm{MnO}$ & 0,02 & $<0.01$ & $<0.01$ & $<0.01$ & 0,01 & 0,01 & $<0.01$ & 0,02 & 0,02 & $<0.01$ & 0,01 \\
\hline $\mathrm{MgO}$ & 0,26 & 0,25 & 0,24 & 0,33 & 0,17 & 0,27 & 0,28 & 0,34 & 0,81 & 0,13 & 0,26 \\
\hline $\mathrm{CaO}$ & 1,29 & 0,46 & 1,35 & 0,63 & 0,83 & 1,56 & 0,89 & 1,54 & 1,13 & 1,12 & 1,47 \\
\hline $\mathrm{Na} 2 \mathrm{O}$ & 1,85 & 3,76 & 4,29 & 4,02 & 4,4 & 3,95 & 4,03 & 3,68 & 3,23 & 3,66 & 3,89 \\
\hline $\mathrm{K} 2 \mathrm{O}$ & 4,55 & 3,78 & 3,58 & 3,12 & 3,66 & 3,06 & 2,98 & 3,43 & 5,09 & 4,18 & 3,29 \\
\hline $\mathrm{P} 2 \mathrm{O} 5$ & 0,88 & 0,07 & 0,06 & 0,14 & 0,12 & 0,88 & 0,09 & 0,1 & 0,3 & 0,09 & 0,07 \\
\hline P.F & 1,6 & 1,1 & 0,9 & 1 & 0,9 & 1 & 1 & 1 & 1,1 & 0,7 & 1 \\
\hline TOTAL & 99,78 & 99,89 & 99,87 & 99,82 & 99,86 & 99,86 & 99,86 & 99,86 & 99,77 & 99,89 & 99,88 \\
\hline \multicolumn{12}{|l|}{$\mathrm{ppb}$} \\
\hline $\mathrm{Au}$ & 0,6 & $<0.5$ & $<0.5$ & 0,6 & $<0.5$ & $<0.5$ & 1,3 & $<0.5$ & 0,8 & 1 & 1,3 \\
\hline \multicolumn{12}{|l|}{$\mathrm{ppm}$} \\
\hline $\mathrm{Be}$ & 22 & 4 & 11 & 7 & 4 & 15 & 4 & 8 & 8 & $<1$ & 8 \\
\hline $\mathrm{Rb}$ & 326 & 157,3 & 101,4 & 567,6 & 439,7 & 96 & 114,8 & 123,6 & 141,8 & 113,5 & 107 \\
\hline $\mathrm{Cs}$ & 36,1 & 9,3 & 6,4 & 404 & 195,6 & 6,8 & 9,9 & 6,8 & 13,4 & 2,9 & 7,7 \\
\hline $\mathrm{Ba}$ & 250 & 311 & 352 & 338 & 339 & 259 & 353 & 352 & 1022 & 394 & 321 \\
\hline $\mathrm{Sr}$ & 44,2 & 78,6 & 187,1 & 111,1 & 139 & 151,6 & 183,4 & 169,1 & 144,7 & 152,1 & 197,9 \\
\hline $\mathrm{Ga}$ & 18,7 & 15,7 & 15,3 & 16 & 15,4 & 17 & 13 & 16,8 & 17 & 14,9 & 14,1 \\
\hline $\mathrm{V}$ & 39 & 41 & 36 & 31 & 25 & 27 & 30 & 31 & 57 & 46 & 46 \\
\hline $\mathrm{Sn}$ & 900 & 5 & 2 & 47 & 75 & 1 & 3 & 5 & 4 & 2 & 1 \\
\hline W & 1 & 0,6 & $<0.5$ & 3,7 & 5,8 & $<0.5$ & $<0.5$ & $<0.5$ & 0,7 & $<0.5$ & $<0.5$ \\
\hline $\mathrm{Ta}$ & 12 & 0,5 & 0,2 & 0,4 & 2,2 & 0,2 & 0,2 & 0,8 & 0,6 & 0,2 & 0,3 \\
\hline $\mathrm{Nb}$ & 5,3 & 3,8 & 3,1 & 3,7 & 3,6 & 3,3 & 2,2 & 4,6 & 5 & 1,7 & 3,1 \\
\hline Th & 0,8 & 8 & 6,3 & 10 & 3,8 & 7,4 & 10,5 & 5,5 & 6,1 & 2,8 & 5,2 \\
\hline $\mathrm{U}$ & 0,9 & 2,4 & 4 & 3,3 & 2,2 & 6,3 & 3,9 & 5,5 & 4,4 & 2,1 & 2,3 \\
\hline $\mathrm{Zr}$ & 14,2 & 70,7 & 68,6 & 87,8 & 46 & 82,1 & 113,5 & 76,7 & 90,6 & 32 & 58,4 \\
\hline $\mathrm{Hf}$ & 1 & 2,1 & 2,1 & 2 & 1,4 & 1,9 & 3,4 & 2 & 2,3 & 1,1 & 1,4 \\
\hline $\mathrm{Y}$ & 1,1 & 2,1 & 2,2 & 2,8 & 3,8 & 4 & 3,7 & 3,4 & 6,9 & 3,8 & 3,1 \\
\hline $\mathrm{Sc}$ & $<1$ & 1 & 1 & 1 & 1 & 2 & 2 & 2 & 3 & 1 & 1 \\
\hline $\mathrm{La}$ & 2 & 16,5 & 14,9 & 21,2 & 8,4 & 15,5 & 22,5 & 13,4 & 22 & 8,2 & 12,8 \\
\hline $\mathrm{Ce}$ & 3,4 & 28,7 & 26,2 & 36,4 & 15,3 & 27,1 & 39 & 27,2 & 42,4 & 15,8 & 23,7 \\
\hline $\operatorname{Pr}$ & 0,31 & 2,79 & 2,38 & 3,32 & 1,45 & 2,51 & 3,91 & 2,68 & 4,36 & 1,55 & 2,31 \\
\hline $\mathrm{Nd}$ & 0,9 & 9,2 & 7,6 & 10 & 4,9 & 8,3 & 13,3 & 8,1 & 15,4 & 5,6 & 7,1 \\
\hline $\mathrm{Sm}$ & 0.32 & 1,55 & 1,42 & 2,06 & 1,03 & 1,6 & 2,48 & 1,81 & 2,85 & 1,32 & 1,41 \\
\hline $\mathrm{Eu}$ & 0,09 & 0,44 & 0,54 & 0,57 & 0,48 & 0,44 & 0,55 & 0,56 & 0,74 & 0,53 & 0,57 \\
\hline $\mathrm{Gd}$ & 0,18 & 1,23 & 0,98 & 1,52 & 1,01 & 1,25 & 1,8 & 1,67 & 2,39 & 1,1 & 1,27 \\
\hline $\mathrm{Tb}$ & 0,05 & 0,14 & 0,14 & 0,2 & 0,15 & 0,18 & 0,23 & 0,21 & 0,33 & 0,18 & 0,16 \\
\hline Dy & 0,08 & 0,6 & 0,42 & 0,78 & 0,62 & 0,83 & 0,98 & 0,97 & 1,37 & 0,93 & 0,63 \\
\hline Ho & $<0.02$ & 0,08 & 0,08 & 0,1 & 0,12 & 0,21 & 0,13 & 0,13 & 0,28 & 0,18 & 0,16 \\
\hline Er & $<0.03$ & 0,1 & 0,16 & 0,19 & 0,41 & 0,27 & 0,23 & 0,22 & 0,44 & 0,35 & 0,26 \\
\hline $\mathrm{Tm}$ & $<0.01$ & 0,01 & 0,03 & 0,03 & 0,04 & 0,03 & 0,03 & 0,03 & 0,08 & 0,05 & 0,03 \\
\hline $\mathrm{Yb}$ & $<0.05$ & 0,1 & 0,09 & 0,16 & 0,36 & 0,12 & 0,35 & 0,24 & 0,51 & 0,13 & 0,17 \\
\hline $\mathrm{Lu}$ & $<0.01$ & 0,03 & 0,03 & 0,03 & 0,05 & 0,04 & 0,03 & 0,03 & 0,06 & 0,05 & 0,02 \\
\hline $\mathrm{Ni}$ & $<0.1$ & $<0.1$ & 0,6 & 0,4 & 0,2 & 0,9 & 0,9 & 0,6 & 6,8 & $<0.1$ & 0,6 \\
\hline $\mathrm{Cr}$ & $<20$ & $<20$ & $<20$ & $<20$ & $<20$ & $<20$ & 27,36 & $<20$ & 20,52 & $<20$ & $<20$ \\
\hline Co & 0,7 & 1,1 & 1,4 & 1,9 & 0,9 & 1,8 & 2 & 2,3 & 5 & 1,1 & 1,4 \\
\hline $\mathrm{Cu}$ & 0,7 & 1,7 & 2,7 & 2,2 & 1,1 & 0,9 & 1,9 & 1,3 & 9,2 & 1,4 & 1,7 \\
\hline $\mathrm{Cd}$ & $<0.1$ & $<0.1$ & $<0.1$ & $<0.1$ & $<0.1$ & $<0.1$ & $<0.1$ & $<0.1$ & $<0.1$ & $<0.1$ & $<0.1$ \\
\hline $\mathrm{Zn}$ & 10 & 6 & 19 & 13 & 4 & 20 & 18 & 18 & 63 & 3 & 13 \\
\hline $\mathrm{Pb}$ & 4,8 & 6,6 & 9,6 & 7,6 & 9,9 & 6,3 & 11,8 & 29,9 & 37,8 & 6,6 & 5,1 \\
\hline Mo & $<0.1$ & $<0.1$ & $<0.1$ & $<0.1$ & $<0.1$ & $<0.1$ & $<0.1$ & $<0.1$ & 0,4 & $<0.1$ & $<0.1$ \\
\hline $\mathrm{Ag}$ & $<0.1$ & $<0.1$ & $<0.1$ & $<0.1$ & $<0.1$ & $<0.1$ & $<0.1$ & 0,2 & 0,1 & $<0.1$ & $<0.1$ \\
\hline As & $<0.5$ & $<0.5$ & $<0.5$ & $<0.5$ & $<0.5$ & $<0.5$ & 1,3 & 0,6 & 1,4 & $<0.5$ & $<0.5$ \\
\hline $\mathrm{Sb}$ & $<0.1$ & $<0.1$ & $<0.1$ & $<0.1$ & $<0.1$ & $<0.1$ & $<0.1$ & $<0.1$ & $<0.1$ & $<0.1$ & $<0.1$ \\
\hline $\mathrm{Bi}$ & $<0.1$ & $<0.1$ & $<0.1$ & $<0.1$ & 0,2 & 0,1 & 0,1 & 0,3 & 0,3 & $<0.1$ & $<0.1$ \\
\hline $\mathrm{Se}$ & $<0.5$ & $<0.5$ & $<0.5$ & 0,5 & $<0.5$ & $<0.5$ & $<0.5$ & $<0.5$ & $<0.5$ & 0 & $<0.5$ \\
\hline $\mathrm{Hg}$ & $<0.01$ & $<0.01$ & $<0.01$ & $<0.01$ & $<0.01$ & $<0.01$ & $<0.01$ & $<0.01$ & $<0.01$ & $<0.01$ & $<0.01$ \\
\hline $\mathrm{Tl}$ & $<0.1$ & $<0.1$ & 0,2 & 0,3 & 0,2 & 0,1 & 0,2 & 0,1 & 0,4 & $<0.1$ & 0,2 \\
\hline
\end{tabular}


Em relação à geoquímica das rochas associadas ao albitito do garimpo Pelotas, foram analisados xisto, monzogranito e tonalito.

Os diagramas de variação de elementos maiores do tipo Harker mostraram que os tonalitos apresentam valores de $\mathrm{SiO}_{2}$ intermediários entre os monzogranitos e albititos. As amostras de tonalitos enriquecidos em $\mathrm{SiO}_{2}$ mostram-se com teores mais elevados de $\mathrm{Al}_{2} \mathrm{O}_{3}$ e $\mathrm{Na}_{2} \mathrm{O}$ e teores mais empobrecidos de $\mathrm{TiO}_{2}, \mathrm{Fe}_{2} \mathrm{O}_{3}, \mathrm{MgO}, \mathrm{CaO}, \mathrm{P}_{2} \mathrm{O}_{5}$ e $\mathrm{K}_{2} \mathrm{O}$.

As amostras dos monzogranitos com teor de $\mathrm{SiO}_{2}$ mais elevado apresentam diminuição nos teores de $\mathrm{TiO}_{2}, \mathrm{Fe}_{2} \mathrm{O}_{3}, \mathrm{MgO}, \mathrm{K}_{2} \mathrm{O}, \mathrm{CaO}, \mathrm{P}_{2} \mathrm{O}_{5}$ e $\mathrm{Al}_{2} \mathrm{O}_{3}$, com o aumento de $\mathrm{SiO}_{2}$, e pequeno aumento de $\mathrm{Na}_{2} \mathrm{O}$, com teores mais baixos de $\mathrm{SiO}_{2}$ (Fig.3.9). $\mathrm{Na}$ amostra FPS-8-6-25,90, houve dispersão nos resultados: foi observado teor mais baixo de $\mathrm{SiO}_{2}$, apresentando aumento de $\mathrm{TiO}_{2}, \mathrm{Fe}_{2} \mathrm{O}_{3}, \mathrm{MgO}, \mathrm{P}_{2} \mathrm{O}_{5}$ e $\mathrm{K}_{2} \mathrm{O}$, e teores moderados de $\mathrm{CaO}, \mathrm{Al}_{2} \mathrm{O}_{3}$ e $\mathrm{Na}_{2} \mathrm{O}$. Os xistos analisados apresentaram valores de P.F. entre 4,3 e $5,3 \%$. O teor de $\mathrm{SiO}_{2}$ nessas amostras mostrou-se muito baixo (49,83 a 50,29\%). Já os valores de $\mathrm{Al}_{2} \mathrm{O}_{3}, \mathrm{TiO}_{2}, \mathrm{Fe}_{2} \mathrm{O}_{3}, \mathrm{MgO}, \mathrm{CaO}$ e $\mathrm{K}_{2} \mathrm{O}$ apresentaram-se altos, e teores de $\mathrm{Na}_{2} \mathrm{O}$ e $\mathrm{P}_{2} \mathrm{O}_{5}$ foram baixos (Fig.3.8).

O diagrama do tipo Harker para os elementos-traço mostra que os tonalitos apresentaram aumento em $\mathrm{Ba}$ e $\mathrm{Sr}$,com elevação de $\mathrm{SiO}_{2}$ e diminuição de $\mathrm{Zr}$, $\mathrm{Rb}$ e Th. Foi verificado, também, o empobrecimento de $\mathrm{Sn}, \mathrm{Nb}$ e Ta nessas rochas (Fig. 3.10). Para os monzogranitos, houve aumento de $\mathrm{Ba}$, Th e $\mathrm{Zr}$ e diminuição de $\mathrm{Sr}$ com o aumento de $\mathrm{SiO}_{2}$. Os teores de $\mathrm{Rb}$ mostraram dispersão no resultados: algumas amostras apresentaram alto teor de $\mathrm{Rb}$, se destoando das demais. Houve empobrecimento em Sn, $\mathrm{Nb}$ e Ta (Fig. 3.10). A única exceção foi a amostra FPS-4-7-26,35, que apresentou teor de 900 ppm de Sn. Porém, o Sn pode ser devido ao fato dessa amostra possuir mistura de monzogranito e albitito. Os xistos são enriquecidos em $\mathrm{Ba}, \mathrm{Zr}$ e Th e empobrecidos em $\mathrm{Sn}, \mathrm{Nb}$ e Ta. Apresentam valores moderados de Rb. Já os teores de Sr mostraram-se diferentes nas duas amostras analisadas (Fig. 3.8). 

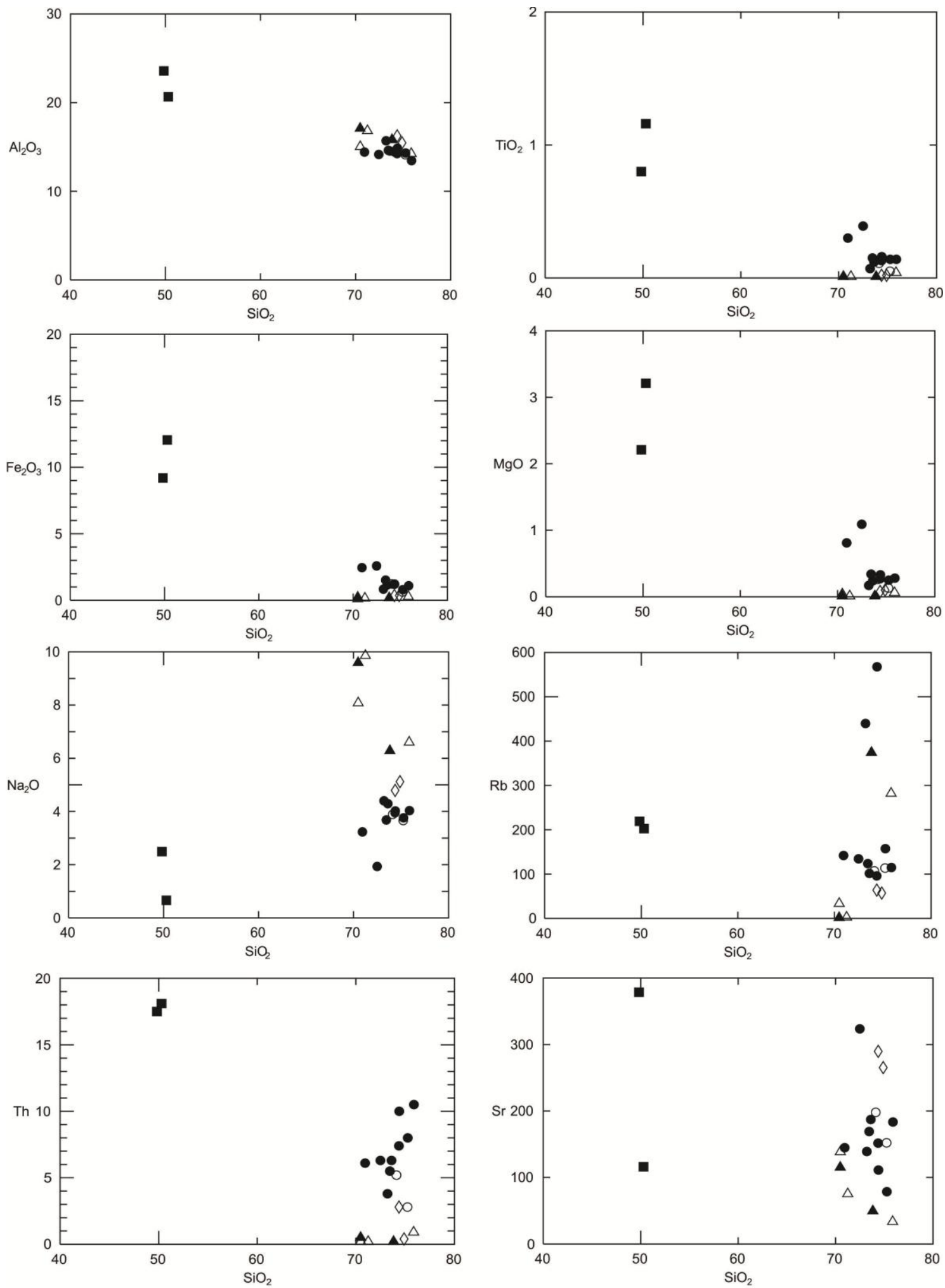

Xisto

- Muscovita-biotita monzogranito o Biotita-muscovita monzogranito

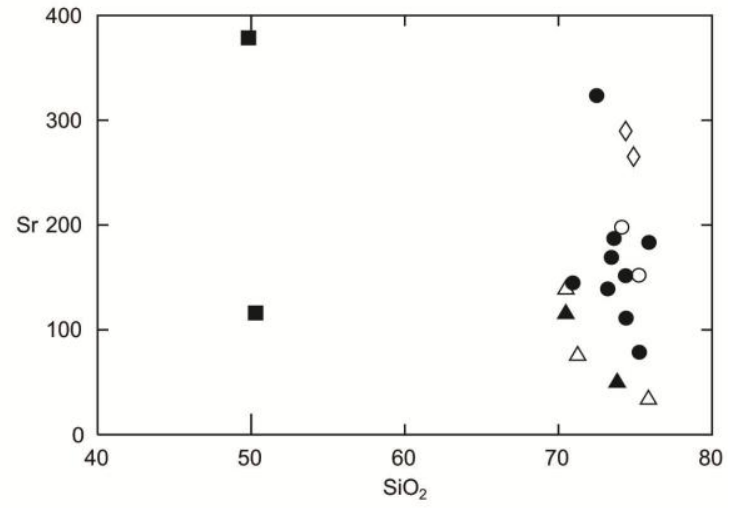

$\diamond$ Biotita-muscovita tonalito $\triangle$ Albitito Pelotas

$\Delta$ Albitito Boa Vista

Figura 3.8: Diagramas de variação de elementos maiores e traços em relação a $\mathrm{SiO}_{2}$, em comparação com os xistos, monzogranitos, tonalitos e albititos. 

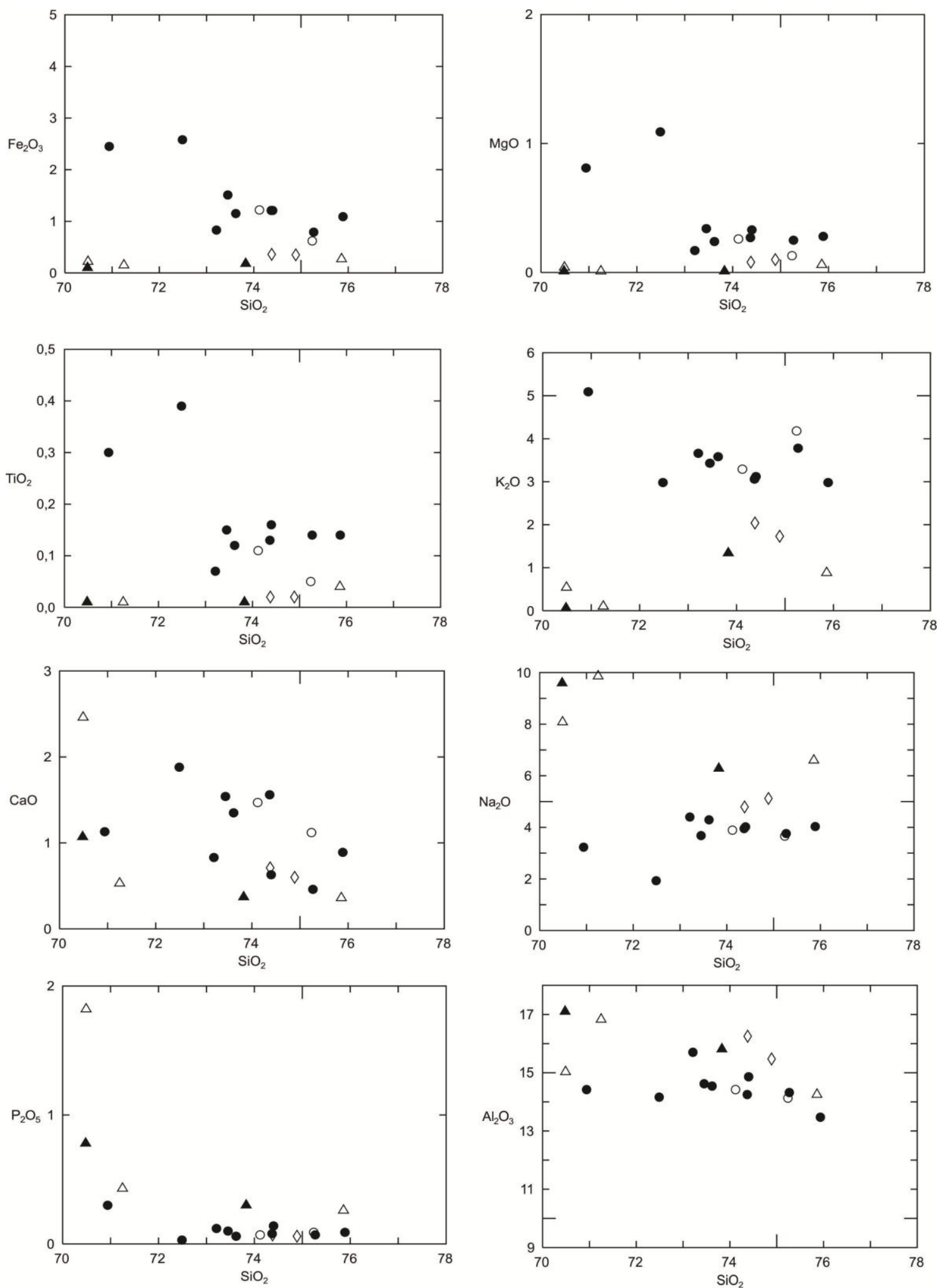

- Biotita-muscovita monzogranito o Biotita-muscovita monzogranito $\diamond$ Biotita-muscovita tonalito

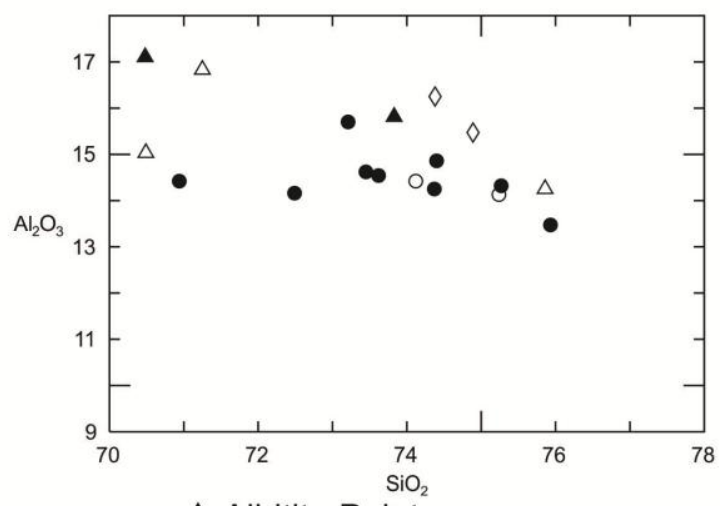

$\triangle$ Albitito Pelotas

$\Delta$ Albitito Boa Vista

Figura 3.9: Diagramas de variação de elementos maiores em relação a $\mathrm{SiO}_{2}$, como índicede diferenciação, para os monzogranitos e tonalitos e dos albititos dos garimpos Pelotas e Boa Vista. 

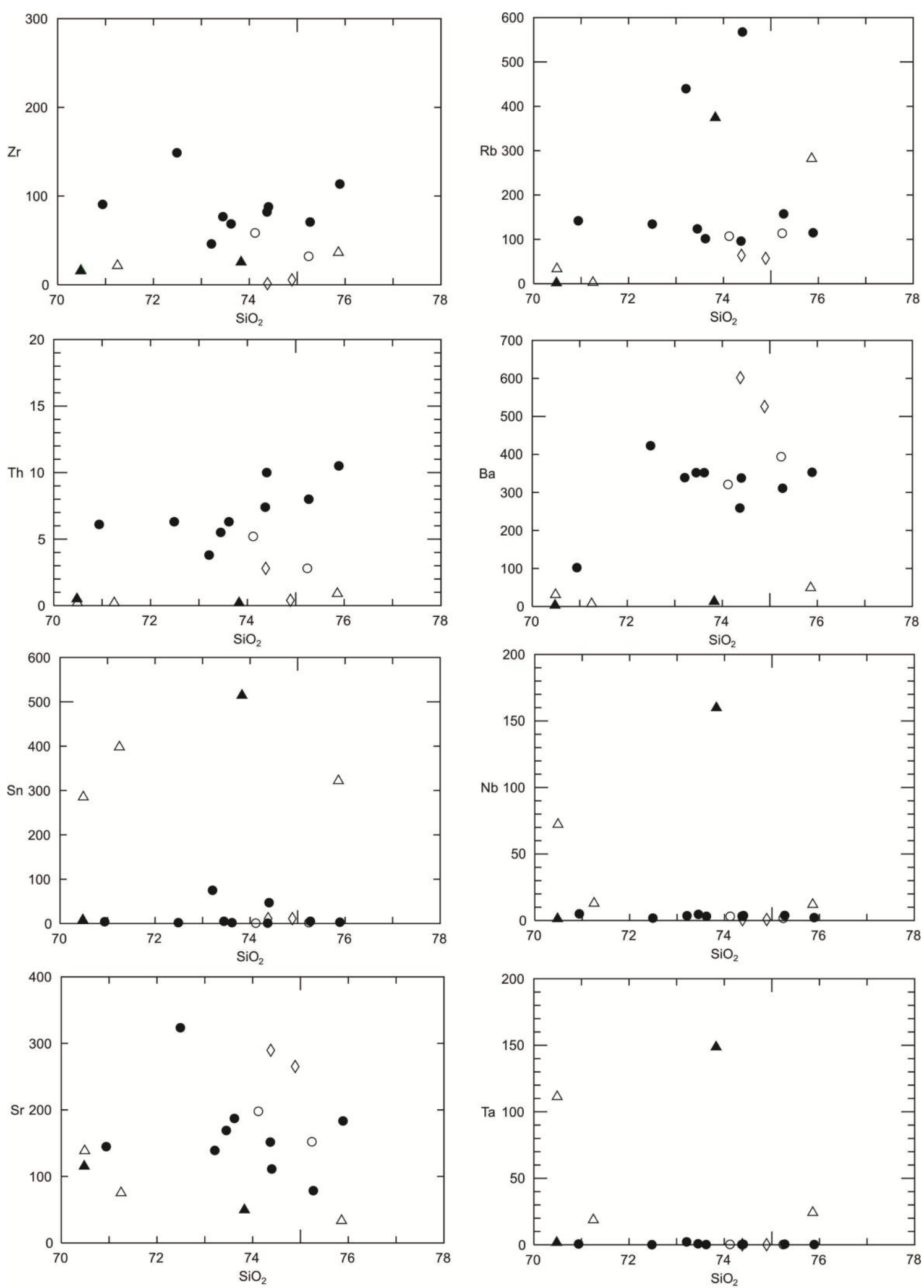

- Muscovita-biotita monzogranito - Biotita-muscovita monzogranito $\diamond$ Biotita-muscovita tonalito

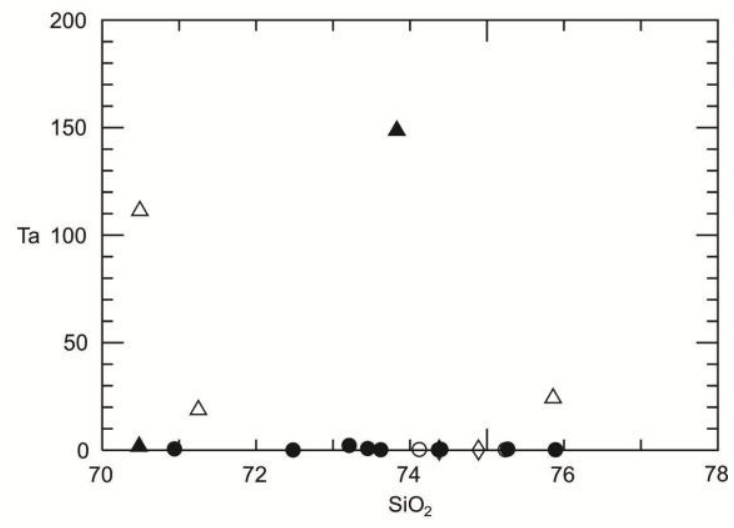

$\triangle$ Albitito Pelotas

A Albitito Boa Vista

Figura 3.10: Diagramas de variação de elementos-traço em relação ao $\mathrm{SiO}_{2}$, como índice de diferenciação, para os monzogranitos e tonalitos e dos albititos dos garimpos Pelotas e Boa vista. 


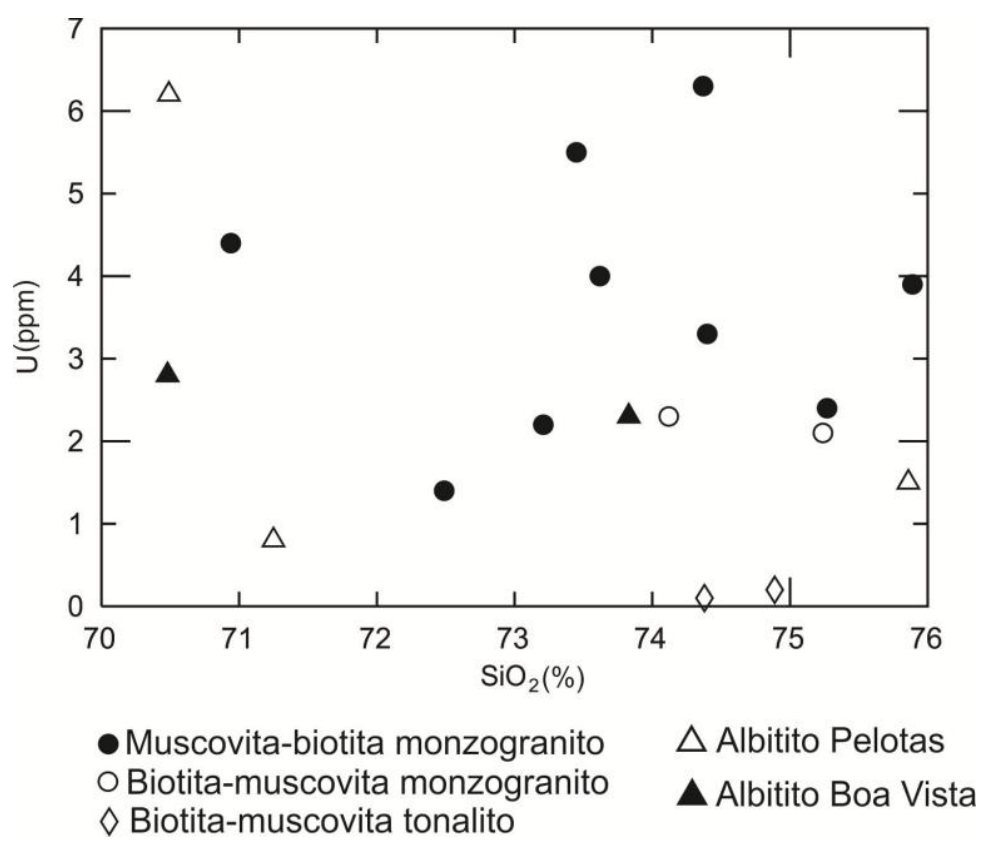

Figura 3.11: Relação entre $\mathrm{U}$ e $\mathrm{SiO}_{2}$, mostrando o empobrecimento do $\mathrm{U}$ tanto nos albititos como nos monzogranitos e tonalitos.

O conteúdo de $\mathrm{U}$, tanto nos granitos e tonalitos quanto nos albititos, é bastante baixo $(<7 \mathrm{ppm})$, sendo observado teor mais elevado em rochas com conteúdo baixo de $\mathrm{SiO}_{2}$ (Fig. 3.11).

Altos teores de U são documentados em vários depósitos que apresentam os albititos como rocha hospedeira. Todavia, os albititos são de origem hidrotermal, sendo esse o principal processo responsável pela lixiviação do U e pelo seu posterior enriquecimento nessas rochas, chegando a 3566 ppm (Chaves 2005). Outra explicação é terem passado por processos metamórficos nos quais o enriquecimento de urânio no fluido foi derivado de minerais acessórios máficos, como titanita, allanita e hematita (Chaves 2013, Polito et al. 2007).

\subsubsection{ELEMENTOS TERRAS RARAS}

Os resultados analíticos de elementos terras raras (ETR) foram normalizados em relação aos condritos, conforme osvalores de Nakamura (1974).

Os padrões de ETR para os albititos mostram um leve enriquecimento em elementos terras raras leves (ETRL) em relação aos elementos terras raras pesados (ETRP). Os ETRM apresentam padrão plano em todas as amostras analisadas. As 
anomalias de Eu são ausentes ou muito discretas, sendo levemente positivas (Eu/Eu* varia de 1 a 1,7). Os padrões são levementea fortemente fracionados $\left(\mathrm{La}_{\mathrm{n}} / \mathrm{Yb}_{\mathrm{n}} \mathrm{Varia}\right.$ de 2,6 a 30) (Fig.3.12a).
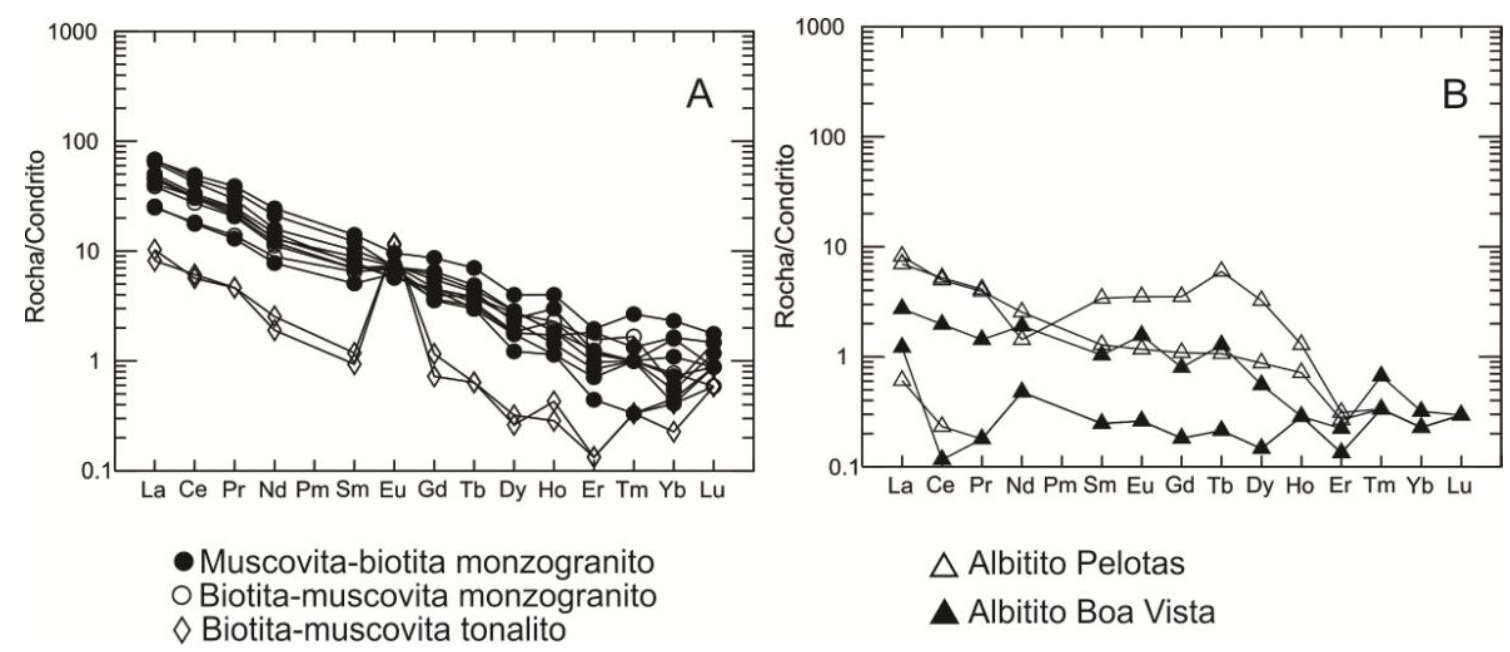

Figura 3.12: Comportamento dos ETR normalizados para valores condríticos segundo Nakamura, 1974) a) para os albititos; b) para os xistos, monzogranitos e tonalitos.

Os padrões de ETR para os granitos mostram que são enriquecidos em ETRL e empobrecidos em ETRP. Asanomalias de Eu são muito discretas, podendo ser levemente positivas ou negativas $\left(0,99<\mathrm{Eu} / \mathrm{Eu}^{*}<1,44\right)$. Apresentam também uma leve anomalia negativa de Er e uma leve anomalia positiva e negativa de Tm. Os padrões são levemente a fortemente fracionados $\left(\mathrm{La}_{\mathrm{n}} / \mathrm{Yb}_{\mathrm{n}}\right.$ varia de 15,6 a 110,7) (Fig.3.12b).

Para os tonalitos, os padrões de ETR mostram-se enriquecidos em ETRL em relação aos ETRP. Apresentam pronunciada anomalia positiva de $\mathrm{Eu}(\mathrm{Eu} / \mathrm{Eu} *$ varia de 2 a 14) e anomalias positivas de Ho e negativas de Er. Os padrões são fortemente fracionados $\left(\mathrm{La}_{\mathrm{n}} / \mathrm{Yb}_{\mathrm{n}}\right.$ varia de 20 a 106) (Fig.3.12b).

O comportamento dos ETR para os xistos apresenta um leve enriquecimento de ETRL em relação aos ETRP e possui discreta anomalia negativa de Eu (Eu/Eu*=0,74). Os padrões são levemente fracionados $\left(\mathrm{La}_{\mathrm{n}} / \mathrm{Yb}_{\mathrm{n}}\right.$ varia de 9,7 a 13).

Os albititos, tonalitos ealguns monzogranitos estudados apresentam anomalias positivas de Eu. Os tonalitos possuem anomalia mais pronunciada, porém, apresentam teores absolutos de Eu baixos em comparação aos monzogranitos, além de teores elevados de Sr.

Existem algumas hipóteses para explicar tal anomalia. Dall'Agnol (1992), analisando os granitos da Província Rio Negro, também verificou anomalia positiva 
significativa de Eu em algumas amostras com teores absolutos de Eu baixos e elevados teores de Sr. Para explicar tal aspecto, ele atribuiu a essas rochas plagioclásio relativamente cálcico, o que causaria o enriquecimento relativo em európio. Entretanto, o plagioclásio nas rochas estudadas é altamente sódico, tanto nos albititos como nos tonalitos e granitos.

É preciso admitir que outras fases sejam igualmente ricas nesse elemento ou que o plagioclásio dessas amostras tenha sido particularmente enriquecido com $\mathrm{Sr}$, como evidenciado na assinatura geoquímica tanto dos albititos como das rochas associadas estudadas neste trabalho, sendo que os tonalitos apresentam um conteúdo mais elevado de Sr se comparado a outras rochas.

Fases minerais nas rochas estudadas podem contribuir para anomalia positiva de Eu, como a apatita ea granada, tal qual a descriçãode Hanson (1978) e Nascimento (2000). A anomalia levemente positiva de Eu nos albititos também pode ser explicada pela presença de apatita, porém, nesse caso, com baixos valores de $\mathrm{Sr}$, mas valores relativamente altos de $\mathrm{Ca}$.

Nascimento (2000) atribuiua anomalia positiva de európio à prevalência de condições oxidantes, em que o $\mathrm{Eu}^{+3}$ seria a forma estável, incompatível com a estrutura cristalina de feldspatos. O autor atribui essa anomalia, ainda, à acumulação de feldspatos.

Isso foi também evidenciado nos albititos vulcânicos do complexo do sul de Sinai, no Egito. Segundo Azer et al. (2008), a acumulação de feldspatos seria a explicação para a anomalia positiva de európio. Essa hipótese é mais aceita para explicar a anomalia positiva de Eu nos albititos, tonalitos e monzogranitos, uma vez que são derivados de um magma altamente sódico.

A anomalia mais pronunciada nos tonalitos pode ser explicada pelo fato de a acumulação de feldspato sódico ter sido mais intensanessa fase.

\subsubsection{DISCUSSÃO}

\section{Gênese dos albititos}

Com base nas características geoquímicas apresentadas acima sobre os albititos e suas rochas associadas, é possível sugerir quais foram os processos responsáveis pela geração dessas rochas. 
A geoquímica dos albititos hidrotermais e magmáticos é bastante diferente, principalmente em relação aos elementos ditos "imóveis". Segundo Castorina et al. (2006) e Palomba (2001), as ocorrências de albititos de Sardinia Central, na Itália, que apresentam características hidrotermais muitas vezes ainda preservam alguns elementos da rocha original, sendo a albitização acompanhada por aumento em $\mathrm{Na}_{2} \mathrm{O}$ e empobrecimento em $\mathrm{Fe}_{2} \mathrm{O}_{3}, \mathrm{~K}_{2} \mathrm{O}, \mathrm{MgO}, \mathrm{Ba}, \mathrm{Pb}, \mathrm{Zn}$ e V. Em contraste, $\mathrm{SiO}_{2}, \mathrm{TiO}_{2}$ e Th são tipicamente imóveis, $\mathrm{Al}_{2} \mathrm{O}_{3}$ e $\mathrm{Sr}$ mostram um ligeiro enriquecimento, e os dados para $\mathrm{CaO}, \mathrm{P}_{2} \mathrm{O}_{5}, \mathrm{Y}, \mathrm{Zr}$, Nb e U sugerem um comportamento quase imóvel.

Em contrapartida, os albititos tanto do garimpo Pelotas como do garimpo Boa Vista apresentam similaridade geoquímica com os albititos discutidos por Azer et al. (2008), Schwartz (1992), Wang et al. (2014) e Pin et al. (2006), interpretados por possuírem origem magmática, com alto conteúdo de $\mathrm{SiO}_{2}, \mathrm{Al}_{2} \mathrm{O}_{3}$ e $\mathrm{Na}_{2} \mathrm{O}$ e baixo conteúdo de $\mathrm{TiO}_{2}, \mathrm{MgO}, \mathrm{Fe}_{2} \mathrm{O}_{3}$ e $\mathrm{K}_{2} \mathrm{O}$. A única exceção ocorre no conteúdo de $\mathrm{P}_{2} \mathrm{O}_{5}$, sendo mais baixo nos albititos subvulcânicos e vulcânicos de Azer et al. (2008), o que pode ser explicado pela elevada presença de apatita nos albititos estudados neste trabalho.

Em relação aos elementos considerados imóveis, nas rochas associadas,os elementos como, $\mathrm{TiO}_{2}$, Th, $\mathrm{Y}$ e $\mathrm{Zr}$, são mais enriquecidos do que nos albititos, e o $\mathrm{P}_{2} \mathrm{O}_{5}$ e o $\mathrm{Nb}$ ocorrem ao contrário, sendo mais enriquecidos nos albititos.

Segundo Rollinson (1993), elementos como Ti, Zr, Y, Nb e P são relativamente imóveis em fluidos aquosos, a menos que apresentem elevada atividade de F. Isso significa que esses elementos serão estáveis sob condições de hidrotermalismo, intemperismo de fundo do mar e até graus médios de metamorfismo.

$\mathrm{O}$ comportamento do $\mathrm{Nb}, \mathrm{Th}, \mathrm{Y}, \mathrm{P}_{2} \mathrm{O}_{5}$ e $\mathrm{TiO}_{2}$ nos albititos é bastante diferente dos monzogranitos e tonalitos, o Ti comporta-se como elemento compatível, sendo mais enriquecido nas rochas menos evoluídas (xistos) e mais empobrecido nas rochas mais evoluídas (albititos), e isso está de acordo com a evolução magmática das rochas em questão.

$\mathrm{O}$ conteúdo de $\mathrm{Nb}$ e $\mathrm{P}_{2} \mathrm{O}_{5}$ é mais acentuado nos albititos. Por outro lado, o conteúdo de Th e Y é menor nos albititos, indicando que esses elementos tiveram comportamento compatível com a fase sólida durante os processos de diferenciação.

O diagrama do tipo Harker para os elementos maiores e traços indica que o processo de cristalização fracionada foi um mecanismo muito importante na evolução 
magmática dessas rochas, evidenciado pelo empobrecimento em $\mathrm{TiO}_{2}, \mathrm{MgO}, \mathrm{FeO}, \mathrm{CaO}$, $\mathrm{Sr}, \mathrm{P}_{2} \mathrm{O}_{5}$ e $\mathrm{Zr}$ e pelo enriquecimento em $\mathrm{Ba}$ e $\mathrm{Na}_{2} \mathrm{O}$. O conteúdo de $\mathrm{Rb}$ e $\mathrm{K}_{2} \mathrm{O}$ diminui nos tonalitos e monzogranitos com o aumento de $\mathrm{SiO}_{2}$. Já nos albititos, o conteúdo de $\mathrm{Rb}$ e $\mathrm{K}_{2} \mathrm{O}$ aumenta com o aumento de $\mathrm{SiO}_{2}$.

Durante a cristalização dos tonalitos e monzogranitos, houve enriquecimento de $\mathrm{P}_{2} \mathrm{O}_{5}$ no líquido residual, já que o $\mathrm{P}_{2} \mathrm{O}_{5}$ comportou-se como elemento incompatível. Segundo Bea et al. (1992), em granitos peraluminosos, pobres em Ca, do tipo S, o fósforo adquire comportamento incompatível, devido à baixa atividade do Ca. Nos tonalitos e monzogranitos, o $\mathrm{P}_{2} \mathrm{O}_{5}$ apresenta uma gradual diminuição com o aumento de $\mathrm{SiO}_{2}$, porém, devido à baixa atividade do $\mathrm{CaO}$, minerais ricos em $\mathrm{P}_{2} \mathrm{O}_{5}$, como a apatita, não foram cristalizados ou foram cristalizados em pequeno volume. Esse fato indica que o $\mathrm{P}_{2} \mathrm{O}_{5}$ se concentrou no líquido residual. Quando iniciou a cristalização dos albititos, a apatita começou a cristalizar, sendo consumida rapidamente e empobrecendo no líquido final, com o aumento de $\mathrm{SiO}_{2}$, como observado na química dos albititos.

A evolução das rochas estudadas pode ser melhor visualizada nos diagramas do tipo Harker, tendo como índice de diferenciação o $\mathrm{MgO}$ (Fig.3.13), pois o mesmo comporta-se, em geral, como elemento pouco móvel durante os processos de alteração, aos quais as rochas foram submetidos após sua cristalização, conforme descrito no item de petrografia das rochas estudadas. O conteúdo de $\mathrm{Fe}_{2} \mathrm{O}_{3}, \mathrm{~K}_{2} \mathrm{O}, \mathrm{CaO}, \mathrm{Rb}$ e $\mathrm{Sr}$ diminui com a diminuição do $\mathrm{MgO}$.

O comportamento dos ETR em sistema magmático e hidrotermal se diferencia em relação à mobilidade desses elementos. Em sistemas hidrotermais, segundo Rollinson (1993) e Jones et al. (2012), os ETRs são imóveis, porém não totalmente. Em complexos ricos em cloro, a mobilidade dos ETRs é maior do que em complexos ricos em flúor, sendo que ETRL possuem mobilidade maior em relação aos ETRP, mas, ainda sim, muitas vezes, algumas rochas podem representar a composição original da rocha inalterada, salvo algumas exceções. Em sistema magmático, o comportamento dos ETRs depende da natureza das fases acessórias de cristalização (Rollinson 1993). 

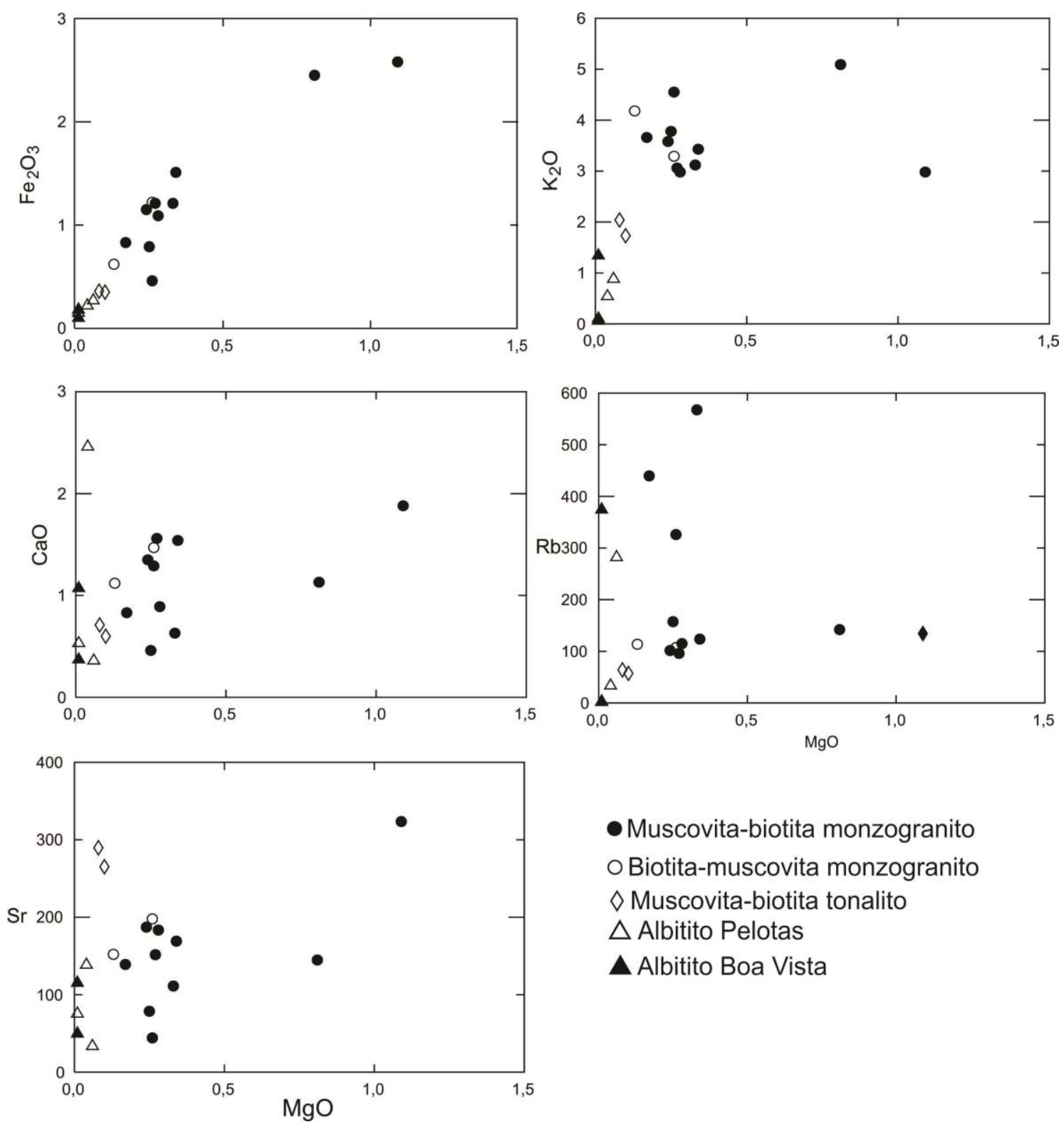

- Muscovita-biotita monzogranito o Biotita-muscovita monzogranito $\diamond$ Muscovita-biotita tonalito $\triangle$ Albitito Pelotas

Albitito Boa Vista

Figura 3.13:Diagramas binários de óxidos e elementos-traço em relação ao $\mathrm{MgO}$, para as rochas graníticas.

O padrão dos ETR nas rochas associadas e dos albititos do garimpo Pelotas se difere um do outro, sendo que a composição dos ETR dos albititos não pode representar a composição das suas rochas associadas, apresentando valores de ETR muito baixos e comportamentos diferentes de alguns elementos (Fig.3.12a,b). Além disso, observa-se também que o conteúdo de ETRL nos albititos é inferior ao das rochas associadas. Isso ocorre porque o plagioclásio empobrece o líquido residual em ETRL.

Os elementos terras raras em albititos de origem hidrotermal, como nos depósitos da França e de Sardinia, na Itália (Boulvais et al. 2007, Castorina et al. 2006), são relativamente imóveis, com exceção do Eu. Já os albititos estudados neste trabalho 
mostram similaridades com os albititos vulcânicos do complexo no sul do Sinai, no Egito, como descrito por Azer et al. (2008), e apresentam, também, anomalias positivas de Eu. Segundo esse mesmo autor, essas anomalias estão ligadas à acumulação de feldspatos.

\section{Ambiente tectônico}

Pearce et al. (1984) introduziram um método geoquímico para caracterizar o ambiente tectônico de rochas graníticas. Os diagramas que usam elementos traços, como $\mathrm{Rb}, \mathrm{Y}, \mathrm{Yb}, \mathrm{Nb}$ e $\mathrm{Ta}$, foram utilizados para distinguir, geoquimicamente, quatro grandes ambientes tectônicos: granitos de cadeias oceânicas (ORG); granitos de arco vulcânico (VAG); granitos intraplaca (WPG) e granitos sin-colisionais (Syn-COLG). Os melhores gráficos discriminantes foram de $\mathrm{Rb} v s$. $(\mathrm{Y}+\mathrm{Nb}), \mathrm{Nb}$ vs. $\mathrm{Y}, \mathrm{Rb} v s$. $(\mathrm{Ta}+$ Yb)e Ta vs. Yb (Fig.3.14). Esse esquema é amplamente utilizado e é considerado como uma importante forma de determinar o ambiente tectônico de rochas graníticas cujo ambiente tectônico não foi preservado.

No diagrama $\mathrm{Rb}$ vs. $(\mathrm{Y}+\mathrm{Nb})$, as amostras de tonalitos e monzogranitos foram plotadas no limite do campo dos granitos de arco vulcânico (VAG) e sin-colisionais (syn-COLG), sendo que os granitos mostraram-se mais ricos em $\mathrm{Rb}$ e $\mathrm{Y}+\mathrm{Nb}$ do que os tonalitos. No diagrama $\mathrm{Rb}$ vs. $(\mathrm{Ta}+\mathrm{Yb})$, as amostras de tonalitos e monzogranitos também se posicionaram no limite do campo dos granitos de arco vulcânico e sincolisionais, sendo que uma amostra de granito se situou no campo dos granitos intraplaca.

Características de campo, petrográficas e geoquímicas são coerentes com a interpretação de que os monzogranitos e tonalitos foram gerados em ambientem sincolisionais. Chappell \& White (1974) reconheceram tipos diferentes de granitos no Lachlan Fold Belt, no leste da Austrália. Um dos tipos identificados é fortemente peraluminoso, relativamente potássico e com composição de sílica restrita (64-77\% de $\mathrm{SiO}_{2}$ ). Chappell \& White (1974) chamaram esses granitos de tipo $\mathrm{S}$, pois infere-se que tenham se formado da fusão de rochas metassedimentares. As rochas graníticas apresentam características de rochas do tipo-S, com teor de $\mathrm{SiO}_{2}$ muito restrito, entre 70,94 e 75,89\%. Esse tipo de rocha é relativamente potássico $(1,73$ a 5,09\%) e fortemente peraluminoso, apresentando, em sua composição mineralógica, muscovita e granada. Além disso, é fortemente deformado e ocorre em ambiente sin-colisional. 

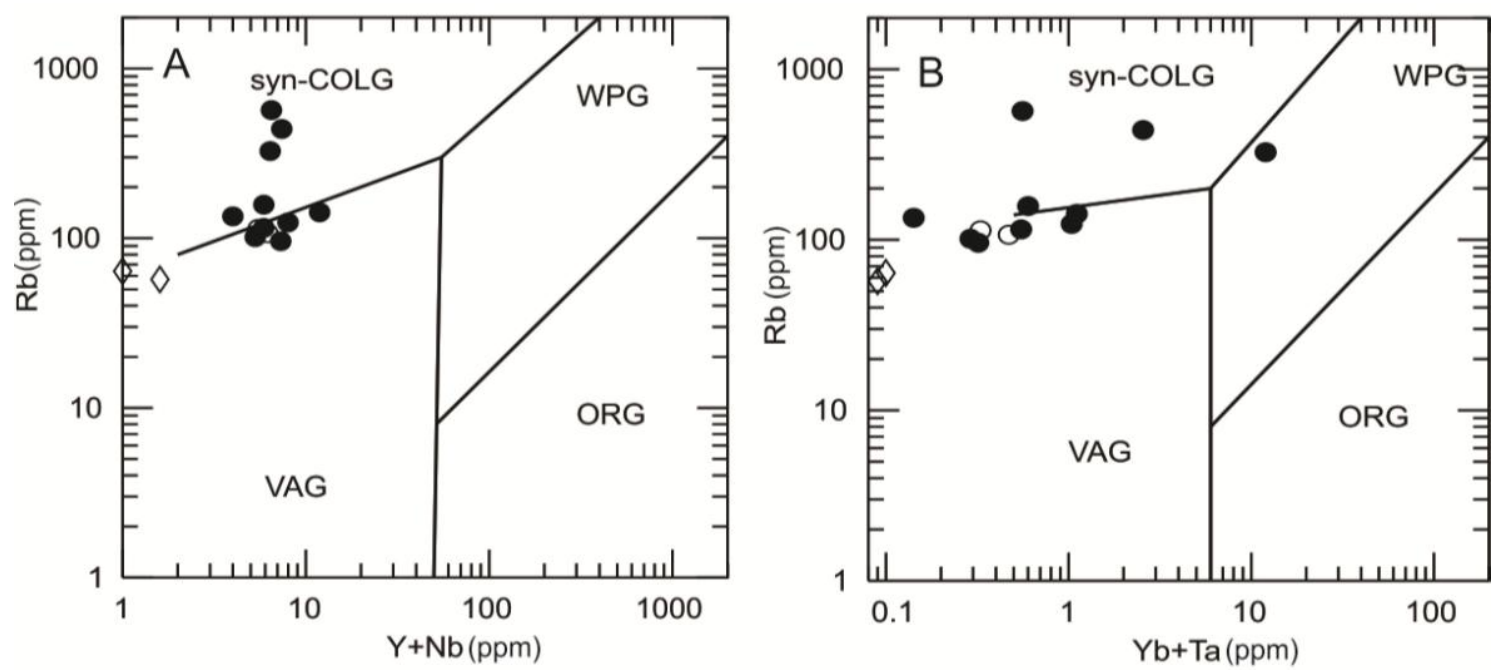

- Muscovita-biotita monzogranito

o Biotita-muscovita monzogranito

$\diamond$ Biotita-muscovita tonalito

Figura 3.14:Amostras de monzogranito e tonalito plotadas nos diagramas discriminantes de ambiente tectônico de Pearce et al. (1984).

O diagrama multielementar normalizado aos granitos de cadeias oceânicas (ORG), segundo Pearce et al. (1984), para as rochas graníticas, mostra anomalia positiva de $\mathrm{Rb}$, Th, Ce e $\mathrm{Sm}$ e fraca anomalia negativa de $\mathrm{Y}$, Ta e $\mathrm{Nb}$ (Fig. 3.15). Segundo Pearce (1982), a relação do empobrecimento de Nb e Ta, em comparação com outros elementos altamente incompatíveis é provavelmente a característica geoquímica mais proeminente de magmas produzidos em zonas de subducção. Essa anomalia negativa indica contribuição de fontes anteriormente subductadas. Pearce et al. (1984) atribuíram o enriquecimento de $\mathrm{Rb}$ e Th relativamente a $\mathrm{Nb}$ e Ta, e de $\mathrm{Ce}$ e $\mathrm{Sm}$, em relação aos seus elementos adjacentes a envolvimento crustal, além de descrever esse tipo de padrão como crust dominated. Os padrões dos elementos mostram que os monzogranitos e tonalitos estudados no presente trabalho apresentam semelhanças com os granitos do Tibete (granitos sin-colisionais-syn-COLG). 


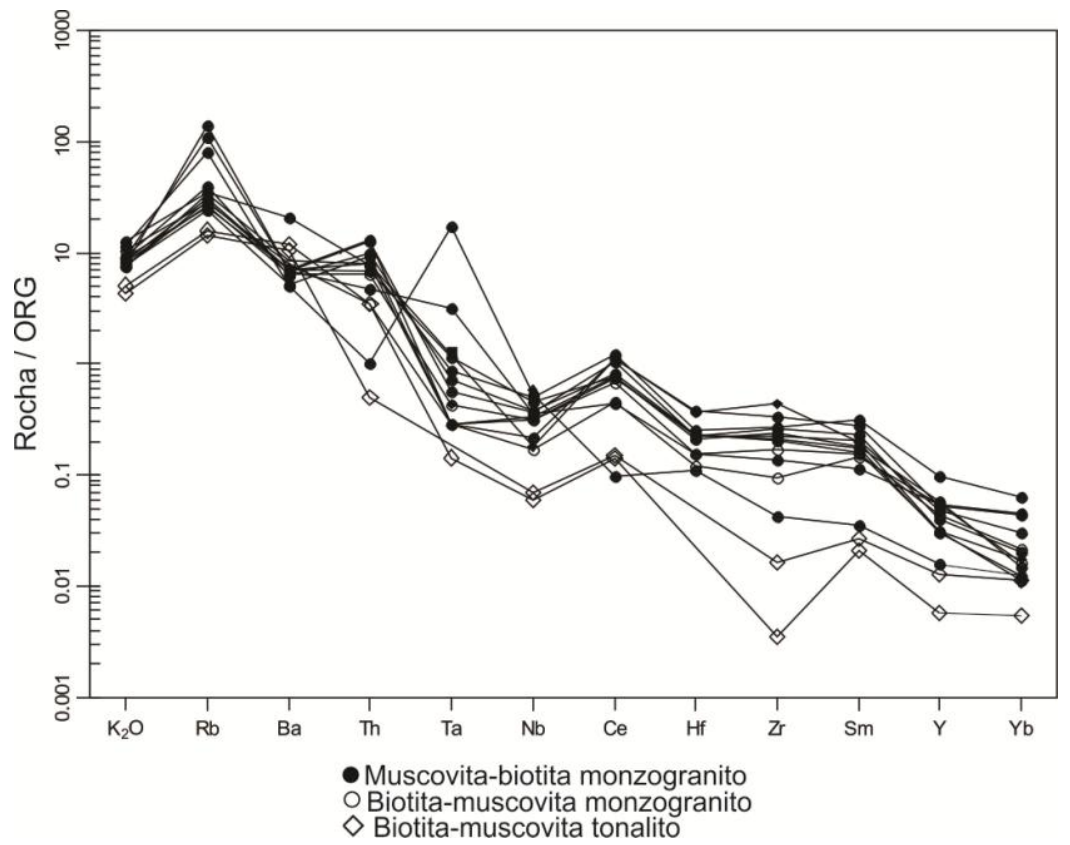

Figura 3.15: Comportamento dos elementostraços normalizados aos granitos de cadeias oceânicas (ORG) dos granitos e tonalitos, segundo Pearceet al. (1984).

No diagrama $\mathrm{Rb} / 100$ - Tb - Ta, de Thiéblemont \& Cabanis (1990), as amostras foram plotadas no campo para rochas ácidas sin-colisionais, porém algumas amostras se posicionaram no campo pós-colisional e sin-subducção (Fig.3.16). Já no diagrama Hf $\mathrm{Rb} / 30$ - 3*Ta, proposto por Harris et al. (1986), as amostras de monzogranitos e tonalitos se posicionaram no campo dos granitos de arco vulcânicos (VA) e granitos sincolisionais (grupo II) (Fig.3.17). Segundo Harris et al. (1986), intrusões peraluminosas sin-colisionais podem ser extraídas de bases hidratadas de lascas continentais e que são caracterizadas por alta razão $\mathrm{Rb} / \mathrm{Zr}$ e $\mathrm{Ta} / \mathrm{Nb}$ e baixas de $\mathrm{K} / \mathrm{Rb}$.

Os dados geoquímicos para discriminar o ambiente tectônico por meio dos gráficos propostos por Pearce et al. (1984), Harris et al. (1986) e Thiéblemont \& Cabanis (1990) mostraram que os monzogranitos e tonalitos caíram no campo dos granitos de origem de arcos vulcânicos e granitos sin-colisionais. Portanto, pode-se concluir que esses granitos foram formados, em ambientes sin-colisionais, de acordo com os seus aspectos mineralógicos e de campo, apresentando deformação.

Essas informações muitas vezes destinam-se, essencialmente, à distinção do ambiente tectônico quando os dados geoquímicos não são muito conclusivos acerca da determinação do ambiente em que as rochas são formadas. Além disso, a composição dos granitos é controlada pela composição da rocha-fonte, e não pelo ambiente tectônico, apesar de ter sido demonstrado que diferentes ambientes tectônicos 
apresentam distintas características de elementos-traço(Förster et al. 1997).

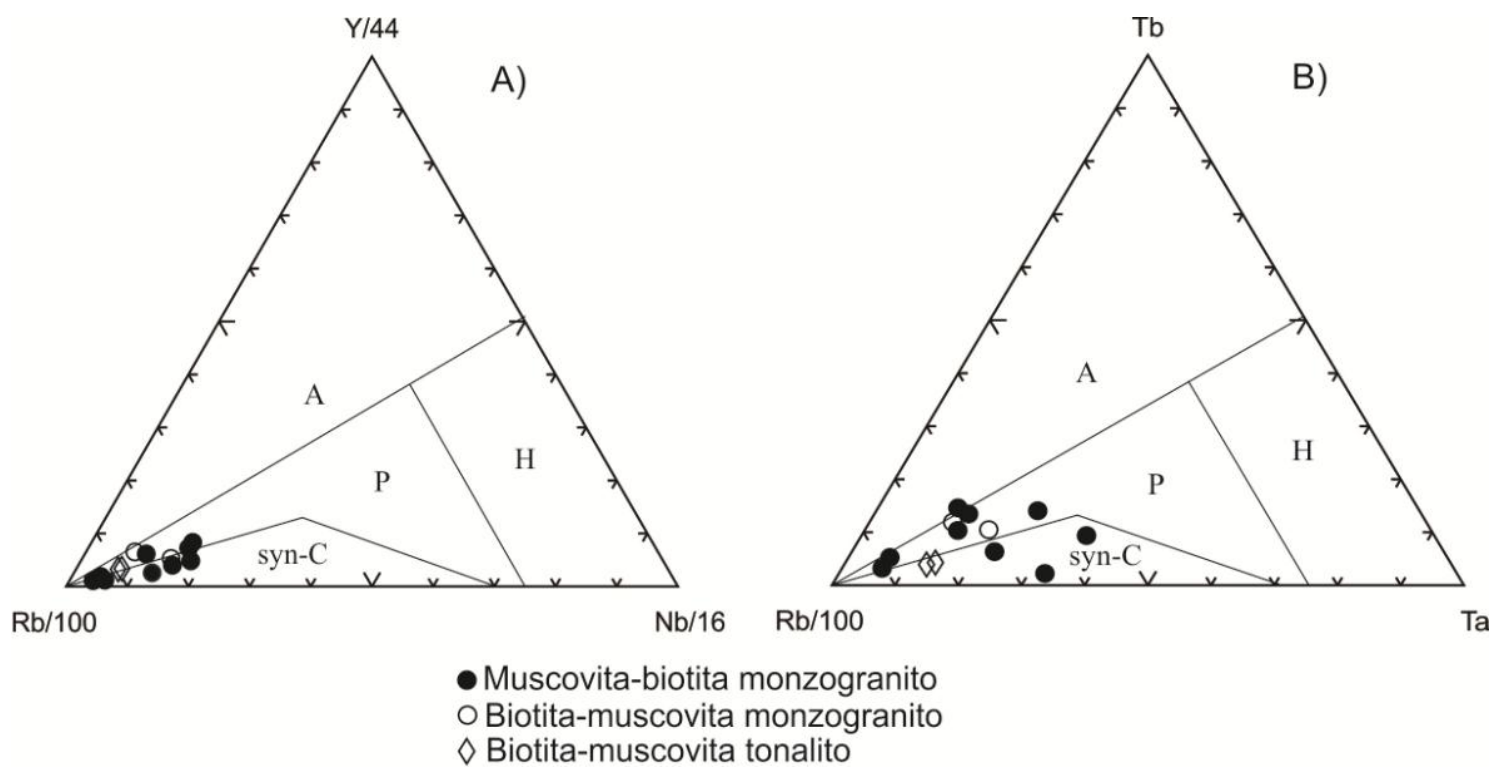

Figura 3.16:Diagramas de discriminação geotectônica das rochas magmáticas ácidas sin-colisionais (synC), pós-colisionais + sin-subduç̧ão $(\mathrm{P})$, anorogênicas não hiperalcalinas $(\mathrm{A})$ e hiperalcalinas $(\mathrm{H})$, propostospor Thiéblemont \& Cabanis (1990).

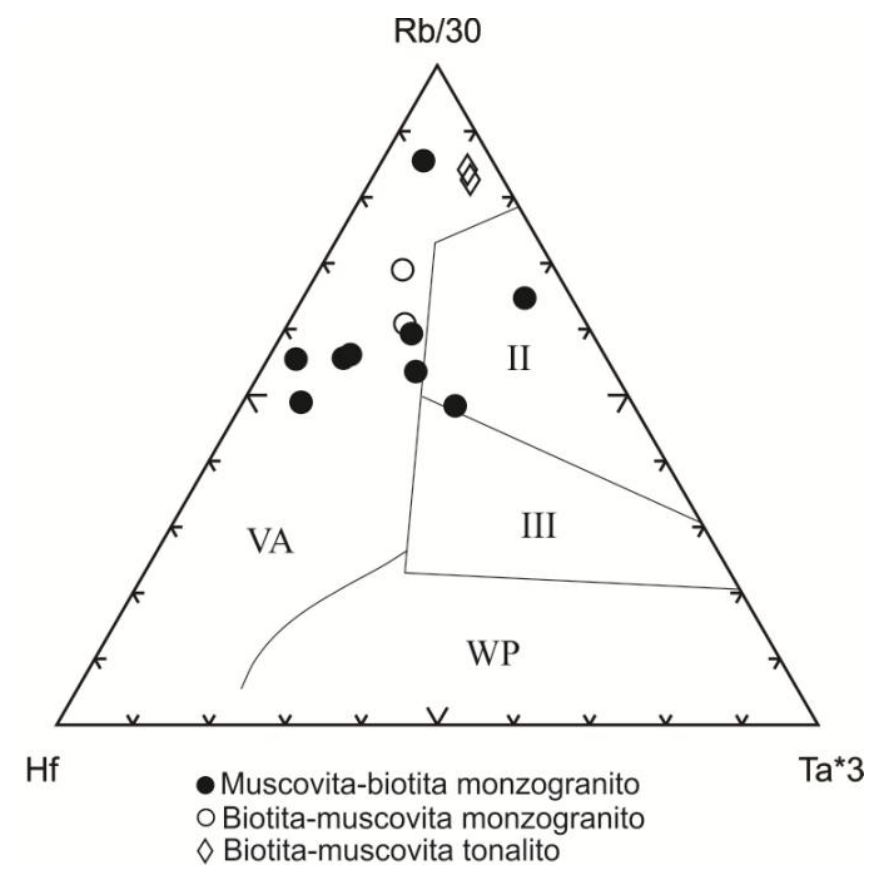

Figura 3.17: Diagrama proposto por Harris et al. (1986), diferenciando os granitos intraplaca (WP) de arco vulcânico (VA), pós-colisionais (grupo III) e sin-colisionais (grupo II) para os granitos e tonalitos.

\subsection{QUÍMICA MINERAL}

O estudo da química mineral objetiva a caracterização química dos minerais e pode contribuir para o entendimento das condições de cristalização das rochas e do seu 
ambiente tectônico. Os minerais analisados neste trabalho foram: plagioclásio, cassiterita, apatita, muscovita e biotita em albititos, monzogranitos e tonalitos.

\subsubsection{PLAGIOCLÁSIO}

Foram realizadas 32 análises em plagioclásio, sendo $13 \mathrm{em}$ albititos, $5 \mathrm{em}$ biotita-muscovita tonalito e 14 em biotita-muscovita monzogranito. Acomposição do plagioclásio variou de albita a albita-oligoclásio (Fig.3.18). A fórmula estrutural do plagioclásio foi calculada com base em 8 oxigênios (Deer et al. 1982), podendo ser escrita genericamente como:

$\left(\mathrm{A}_{\mathrm{x}}^{+1} \mathrm{~A}_{\mathrm{x}}^{+2}\right)\left(\mathrm{B}^{+3}{ }_{2-\mathrm{x}} \mathrm{B}^{+4}{ }_{2-\mathrm{x}}\right) \mathrm{O}_{8}$ (Formula estrutural do plagioclásio)

Albita $\left(\mathbf{A b}_{90-99} \mathbf{A n}_{10-0,6} \mathbf{O r}_{0,4}\right)$ : ocorre nos albititos e na fácies biotita-muscovita tonalito. Apresenta valor de $\mathrm{Na}_{2} \mathrm{O}$ entre 12 e $13 \%$ nos albititos e 10,5 a 11,9\% na fácies biotita-muscovita tonalito, e de $\mathrm{CaO}$ entre 0,05 e $0,6 \%$ e 0,5 e 2,8\%, respectivamente. Foram analisados borda e núcleo em alguns minerais de albita, porém não foi possível determinar diferenças composicionais entre as análises.

A albita dos albititos apresenta composição de quase albita pura, com valor variando de 96 a 99\%. Já a composição da albita da fácies biotita-muscovita tonalito varia de 90 a 97\%, revelando-se um pouco menos sódica em relação aos albititos. Esse tipo de albita é relatado nos albititos de Makawa, no nordeste do Iraque (Mohammad et al. 2007), sendo denominado de albita magmática por esse autor. Mineralogicamente, a albita apresenta hábito euedral a subedral e comumente forma ripas longas e estreitas, com aspecto límpido nos albititos. Na fácies biotita-muscovita tonalito, apresenta hábito subedral a anedral, muitas vezes com aspecto de saussuritização e com maclas polissintéticas pouco visíveis devido à alteração.

Albita-Oligoclásio ( $\left.\mathbf{A b}_{77-99} \mathbf{A n}_{22-1} \mathbf{O r}_{1}\right)$ : essa variedade ocorre apenas na fácies biotita-muscovita granito. Apresenta valor de $\mathrm{Na}_{2} \mathrm{O}$ entre 9,2 a 12,3\%e valor de $\mathrm{CaO}$ entre 0,1 a 4,8\%. Constitui-se na fácies com composição do plagioclásio mais cálcica analisada. Mineralogicamente,esse tipo apresenta hábito subedral a anedral, com maclas polissintéticas pouco visíveis devido à alteração sofrida pelo plagioclásio. Essa alteração, por vezes, é mais visível no núcleo do cristal. A análise foi realizada apenas pontualmente como perfil ao longo do cristal por ter tamanho maior em relação à albita dos albititos. Com isso, observou-se que, à medida que o núcleo do cristal se 
aproximava, ficava mais cálcico em algumas amostras. Em outras, essa variação não foi verificada.

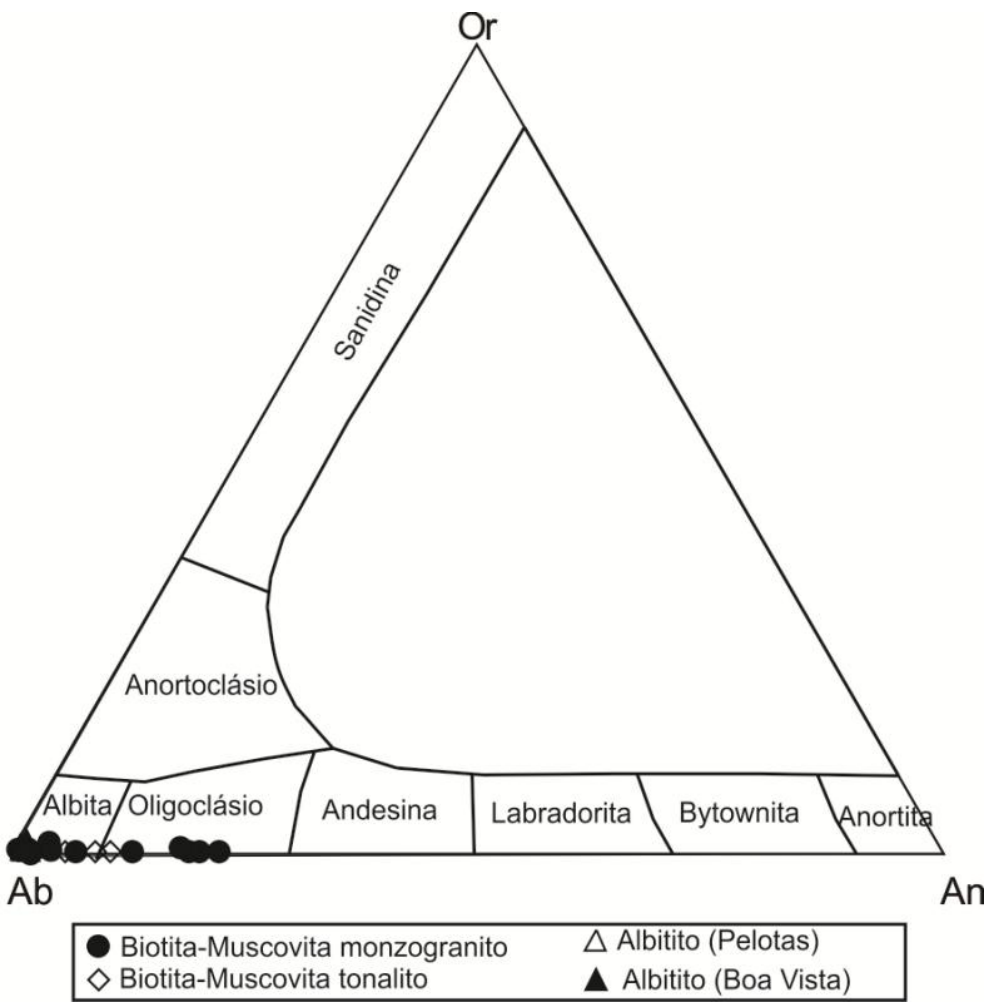

Figura 3.18: Diagrama de classificação dos plagioclásios analisados, evidenciando o caráter altamente sódico.

\subsubsection{CASSITERITA}

Foram realizadas 48 análises de cassiterita, sendo 24 dos albititos do Garimpo Pelotas e 24 dos albititos do garimpo Boa Vista. Os cristais de cassiterita apresentam tamanhos variando de finos a grossos. Os cristais maiores geralmente são zonados, os quais são caracterizados pela alternância de faixas regulares variando de marromavermelhadas a marrom-amareladas, evidenciando, assim, forte pleocroísmo. Já os cristais menores também apresentamzonação, porém sem definição exata da alternância de faixas. Outra característica marcante são as intensas fraturas. A fórmula estrutural para a cassiterita foi calculada com base em 2 átomos de oxigênio.

As análises dos cristais zonados foram concentradas nas partes marromavermelhadas e marrom-amareladas para identificar as variações de teores de alguns elementos nessas faixas. Dessa forma, foram observados dois tipos de variação no conteúdo de alguns elementos, de acordo com a alternância das faixas de cores nos cristais de cassiterita. A faixa marrom-avermelhada mais enriquecida em $\mathrm{Ta}, \mathrm{Nb}$ e Fe é 
mais empobrecida em $\mathrm{Sn}$ e $\mathrm{Sb}$. A faixa marrom-amarelada empobrecida em $\mathrm{Ta}, \mathrm{Nb}$ e $\mathrm{Fe}$ é mais enriquecida em $\mathrm{Sn}$ e $\mathrm{Sb}$, e vice-versa.

$\mathrm{Na}$ figura 3.20, foi feita comparação entre dois cristais de cassiterita dos garimpos Boa Vista e Pelotas. As faixas marrom-avermelhadas são mais enriquecidas em $\mathrm{SnO}_{2}$ e $\mathrm{Sb}_{2} \mathrm{O}_{5}$ e mais empobrecidas em $\mathrm{FeO}, \mathrm{Ta}_{2} \mathrm{O}_{5}$ e $\mathrm{Nb}_{2} \mathrm{O}_{5}$. Em relação às faixas marrom-amareladas, ocorre o inverso.

Já na cassiterita dos albititos do garimpo Pelotas, as faixas marromavermelhadas são mais enriquecidas em $\mathrm{Ta}_{2} \mathrm{O}_{5}$ e $\mathrm{Sb}_{2} \mathrm{O}_{5}$ e mais empobrecidas em $\mathrm{SnO}_{2}$, $\mathrm{Nb}_{2} \mathrm{O}_{5}$ e $\mathrm{FeO}$, ocorrendo o inverso nas faixas marrom-amareladas. No entanto, observou-se que os pontos 3 e 4 que pertencem a faixas diferentes tiveram comportamentos similares com conteúdo maior de $\mathrm{FeO}, \mathrm{Ta}_{2} \mathrm{O}_{5}$ e $\mathrm{Nb}_{2} \mathrm{O}_{5}$, e menor de $\mathrm{SnO}_{2}$. O conteúdo de $\mathrm{Sb}_{2} \mathrm{O}_{5}$ se manteve constante.
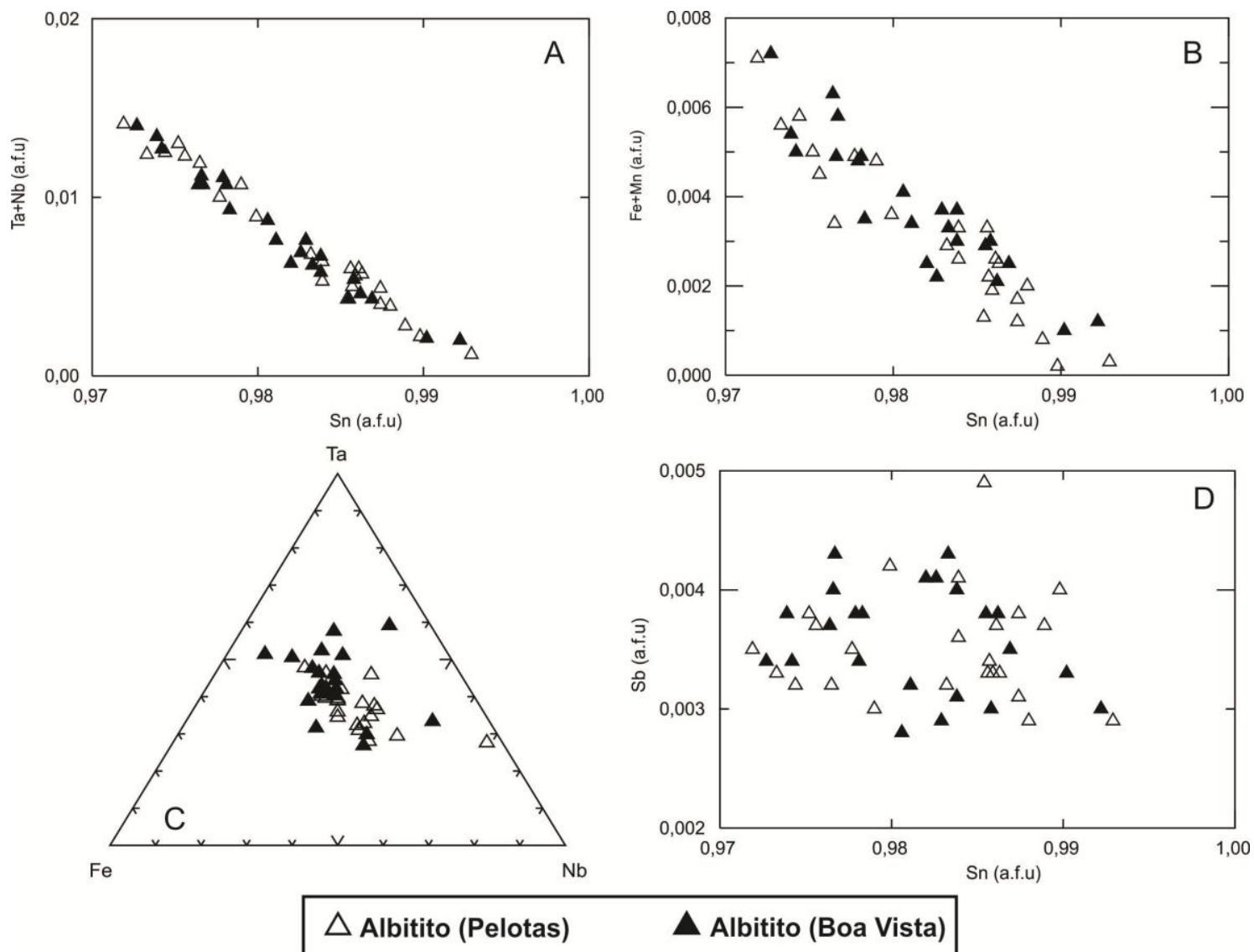

Figura 3.19: Diagrama de correlação atômica das cassiteritas dos garimpos Pelotas e Boa Vista; a) e b) $\mathrm{Ta}+\mathrm{Nb}$ e Fe+Mn vs. Sn, mostrando o comportamento desses elementos na estrutura das cassiteritas; c) Diagrama ternário Fe-Ta-Nb, que mostra a variação química nas cassiteritas; d) Diagrama mostrando o comportamento de $\mathrm{Sb} v$ s. Sn nas cassiteritas. 
Essa variação está ligada à substituição desses elementos na estrutura da cassiterita, em que ocorre o empobrecimento em Sn e ocorre o aumento em $\mathrm{Ta}, \mathrm{Nb}$ e $\mathrm{Fe}$, e vice-versa (Fig.3.19a,b,c), o que é revelado pelas seguintes equações, segundo Möller et al. (1988) e Costi et al. (2000):

a) $\mathrm{Sn}^{4+} \leftrightarrow(\mathrm{Ta}, \mathrm{Nb})^{4+}$;

b) $\mathrm{Sn}^{4+} \leftrightarrow(\mathrm{Ta}, \mathrm{Nb})^{5+}+\mathrm{Fe}^{3+}$;

c) $\mathrm{Sn} 4+\leftrightarrow 2(\mathrm{Ta}, \mathrm{Nb})^{5+}(\mathrm{Fe}, \mathrm{Mn})^{2+}$.

$\mathrm{Fe}, \mathrm{Mn}, \mathrm{Ta}$ e $\mathrm{Nb}$ entram na estrutura cristalina da cassiterita tanto na zona marrom-avermelhada como na zona marrom-amarelada. Isso é evidente nos gráficos de correlação, em que é mostrado que o conteúdo de $\mathrm{Ta}+\mathrm{Nb}$ e Fe+Mn diminui com o aumento do conteúdo de $\mathrm{Sn}$. O gráfico de correlação $\mathrm{Sb} v$. Sn não mostra esse comportamento. $\mathrm{O} \mathrm{Sb}$ apresenta um comportamento constante com o aumento do $\mathrm{Sn}$ (Fig.3.19d). Isso significa que, assim como o $\mathrm{Sn}$, o $\mathrm{Sb}$ também é substituído por Ta, Nb e Fe na estrutura da cassiterita, pois o mesmo acompanha o Sn em tal estrutura.

Nos cristais em que não ocorre zonação, foi realizada análise de núcleo e borda. Observou-se que a borda é mais enriquecida em $\mathrm{Ta}_{2} \mathrm{O}_{5}, \mathrm{Nb}_{2} \mathrm{O}_{5}, \mathrm{Sb}_{2} \mathrm{O}_{5}$ e $\mathrm{FeO}$ e mais empobrecida no núcleo, ao passo que o núcleo é mais enriquecido em $\mathrm{SnO}_{2}$ do que na sua borda.

Cassiterita magmática apresenta teores elevados de $\mathrm{Nb}_{2} \mathrm{O}_{5}(0,063-0,6 \%)$ e $\mathrm{Ta}_{2} \mathrm{O}_{5}$ (0,1-1,3\%). Em contrapartida, cassiterita de origem hidrotermal revelateores baixos em relação a esses elementos, $\mathrm{Nb}_{2} \mathrm{O}_{5}(0,0-0,1 \%)$ e $\mathrm{Ta}_{2} \mathrm{O}_{5}(0,0-0,1 \%)$ (Costi et al. 2000). Esses dados são consistentes com os dados obtidos neste trabalho e com a origem magmática da cassiterita estudada.

Outra importante observação está no conteúdo de $\operatorname{In}_{2} \mathrm{O}_{3}$ na cassiterita analisada. $\mathrm{O}$ conteúdo de $\mathrm{In}_{2} \mathrm{O}_{3}$, o qual, nos cristais de cassiterita estudados, é muito baixo em comparação com cassiterita de origem hidrotermal dos granitos intraplaca (Botelho \& Moura 1998). A concentração de $\mathrm{Ta}_{2} \mathrm{O}_{5}$ na cassiterita estudada é muito alta se comparada com a concentração de $\mathrm{Nb}_{2} \mathrm{O}_{5}$ (Fig.3.21). Esses dados estão de acordo com os valores encontrados emcassiterita das rochas da Suíte Aurumina, enquanto que, em relação aos granitos intraplaca ocorre o inverso (Pereira 2002). 

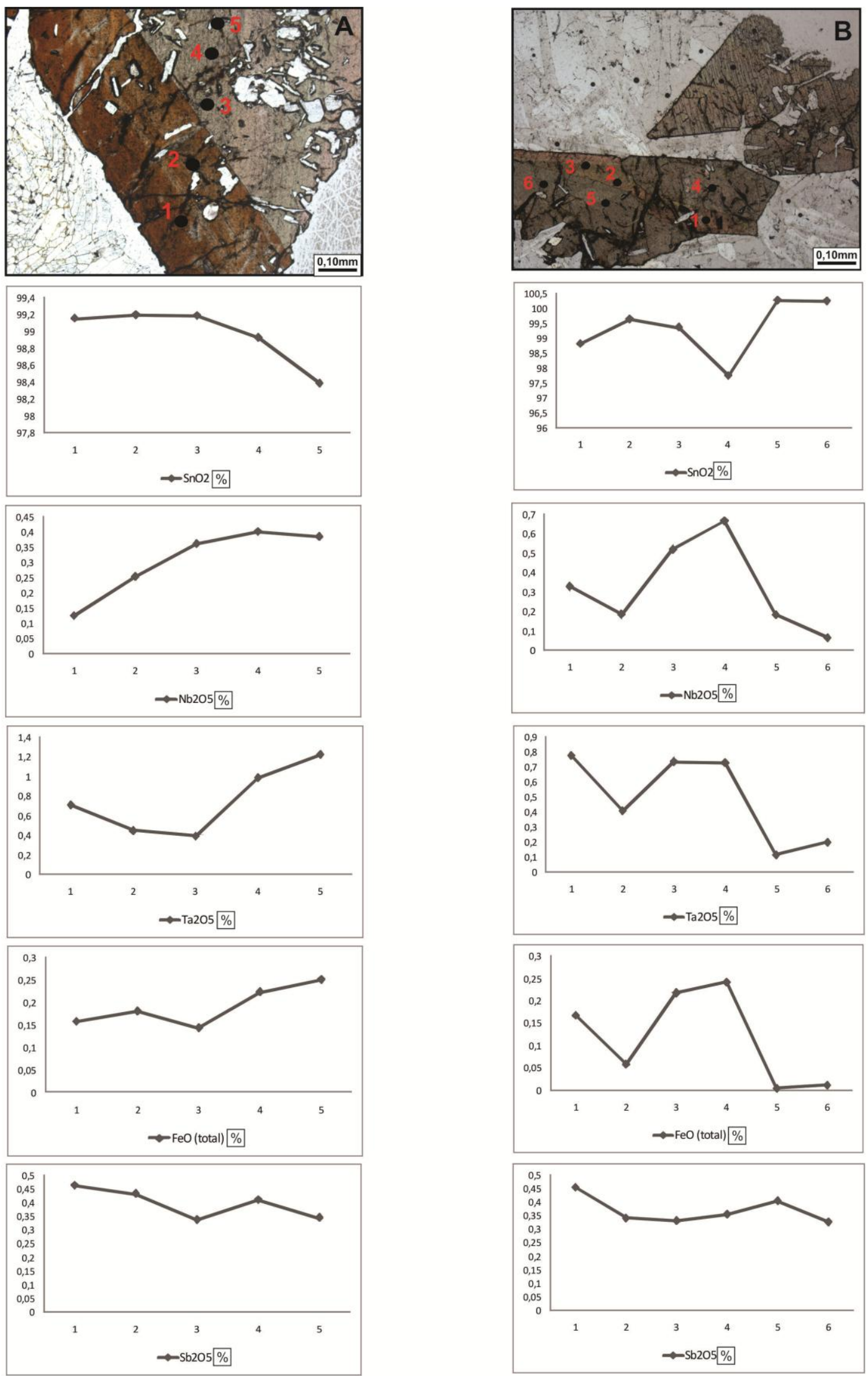

Figura 3.20: a) Cassiterita dos albititos do garimpo Boa Vista; b) Cassiterita dos albititos do garimpo Pelotas, com seus respectivos perfis, que mostram a variação da composição de acordo com as diferentes zonas nesses cristais em porcentagem. 


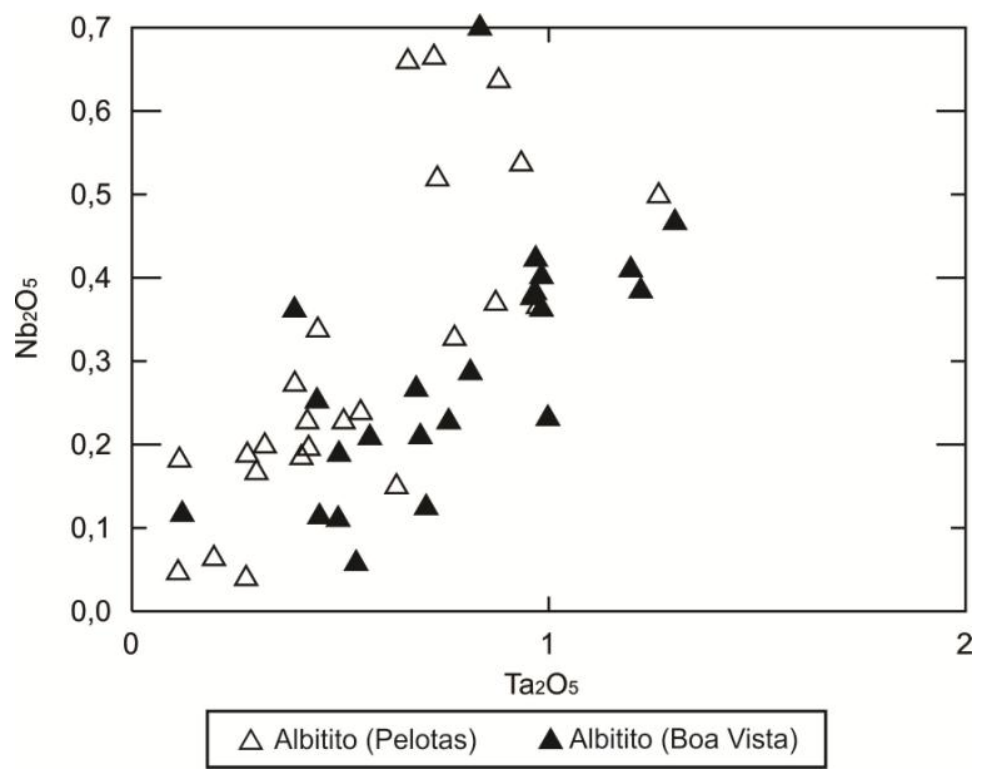

Figura 3.21: Diagrama mostrando a relação $\mathrm{Ta}_{2} \mathrm{O}_{5}(\%)$ vs. $\mathrm{Nb}_{2} \mathrm{O}_{5}(\%)$ na cassiterita dos garimpos Boa Vista e Pelotas.

\subsubsection{BIOTITA}

Foram realizadas 45 análises de biotita, sendo 27 análises da fácies muscovitabiotita tonalito e 18 análises da fácies muscovita-biotita granito. A fórmula estrutural foi calculada com base em 22 átomos de oxigênios, com a fórmula geral podendo ser expressada da seguinte maneira:

$$
\mathrm{K}_{2}\left(\mathrm{Mg}, \mathrm{Fe}^{2+}\right)_{6-4}\left(\mathrm{Fe}^{3+}, \mathrm{Al}, \mathrm{Ti}\right)_{0-2}\left[\mathrm{Si}_{6-5} \mathrm{Al}_{2-3} \mathrm{O}_{20}\right](\mathrm{OH}, \mathrm{F}) .
$$

Mineralogicamente, a biotita apresentam pleocroísmo fraco variando de marrom-pálido a marrom-amarelado. A biotita ocorre comumente associada ao rutilo, sendo, por vezes, substituída por este.

De acordo com o diagrama triangular $10 * \mathrm{TiO}_{2}$ vs. $\mathrm{FeO}+\mathrm{MnO}$ vs. $\mathrm{MgO}$, de Nachit et al. (2005), usado para classificar biotitaem primária, reequilibrada e neoformada, as biotitas estudadas se posicionaram no campo da biotita magmática reequilibrada (Fig.3.22). Apenas uma análise de biotita plotou no campo de biotita primária não reequilibrada. Esta apresenta alto conteúdo de $\mathrm{TiO}_{2}$, cerca de 5,8\%; conteúdo baixo de $\mathrm{MgO}$,com 6,9\%; e conteúdo de $\mathrm{Al}_{2} \mathrm{O}_{3}$ de 15,9\%. Essa biotita pertence à fácies muscovita-biotita tonalito.

A maioria das análises plotouno campo da biotita magmática reequilibradas, tendo conteúdo mais baixo de $\mathrm{TiO}_{2}$, entre 0,8 e 1,7\%. Oconteúdo de $\mathrm{MgO}$ variou de 4,9 a $11,6 \%$, e o conteúdo de $\mathrm{Al}_{2} \mathrm{O}_{3}$, de 15,9 a 22,5\%. 
Segundo Nummer et al. (2007), esse grupo representa a biotita que sofreu modificação composicional por processos de substituições associados a fluidos tardi a pós-magmáticos, sugerindo que as diferenças composicionais apresentada pela biotita desse grupo estejam relacionadas a processos de deformação associados a fluidos hidrotermais. Isso está de acordo com o observado nos tonalitos e monzogranitos estudados, que apresentam evidências de deformação. Entretanto, as rochas preservam textura magmática e as micas primárias analisadas possuem textura ígnea e composição ígnea e bastante homogênea, o que permitem usar os dados de química mineral para estudos petrológicos.

Como o conteúdo de Li não pode ser determinado pela análise de microssonda eletrônica, o cálculo foi baseado na expressão $\mathrm{Li}_{2} \mathrm{O}=\left(0,287 * \mathrm{SiO}_{2}\right)-9,552$ (Tindle \& Webb 1990). O teor de $\mathrm{LiO}_{2}$ na biotita magmática é de $0,13 \%$.

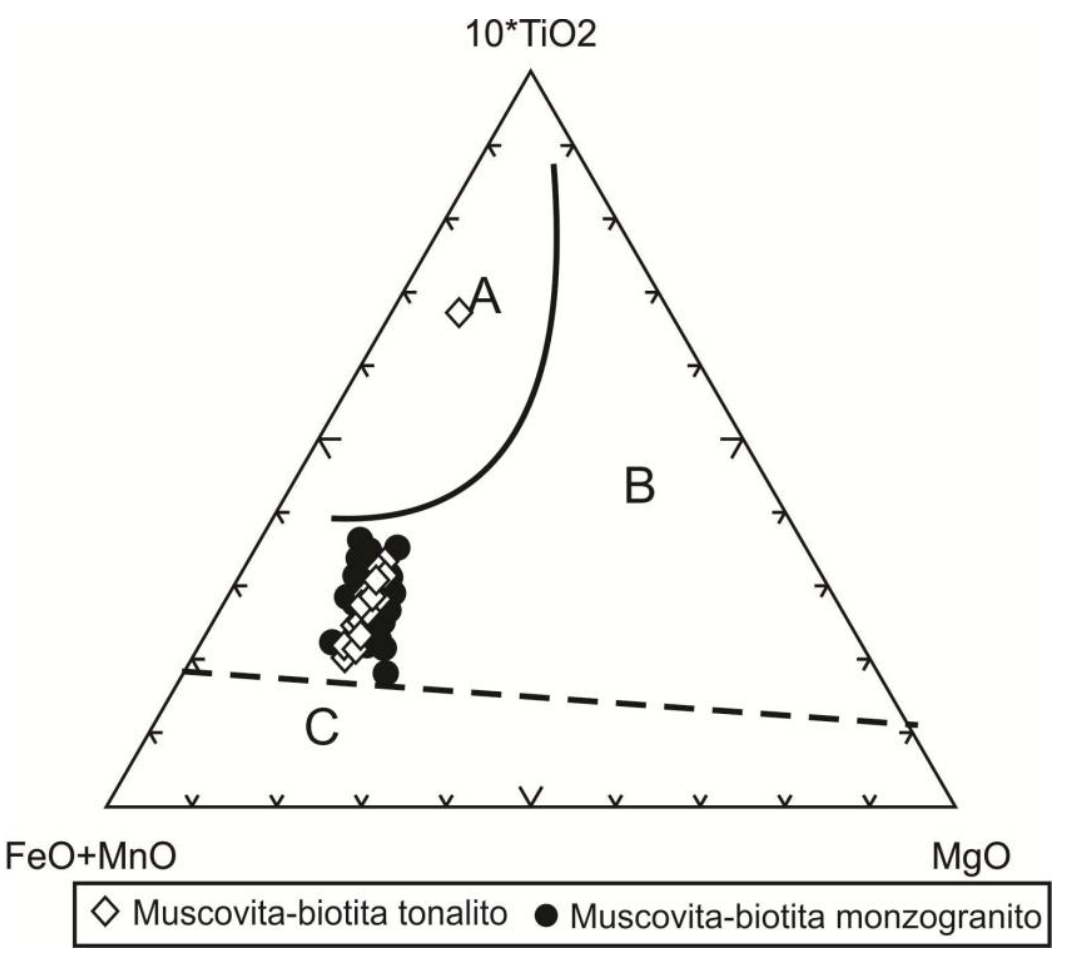

Figura 3.22: Diagrama (FeO+MnO)-(10*TiO )-MgO de Nachit et al. (2005), mostrando as variações composicionais das biotitas analisadas $(\mathrm{A}=$ campo das biotitas magmáticas primárias; $\mathrm{B}=$ campo das biotitas magmáticas reequilibradas; $\mathrm{C}=$ campo das biotitas neoformadas).

O diagrama $\mathrm{Mg} /(\mathrm{Mg}+\mathrm{Fe})$ vs. $\mathrm{Al}^{\mathrm{IV}}$ proposto por Deer et al. (1963) (Fig. 3.23) para as micas trioctaédricas mostra que os cristais de biotita analisadas foram classificadas como siderofilitas, com razão $\mathrm{Fe} /(\mathrm{Fe}+\mathrm{Mg})$ entre 0,58 a 0,71 a.f.u., com conteúdo de $\mathrm{Al}^{\mathrm{IV}}$ entre 2,1 a 3,3 a.f.u. 
A fórmula simplificada para a biotita é do tipo $\mathrm{I}_{2} \mathrm{M}_{6} \mathrm{~T}_{8} \mathrm{O}_{20} \mathrm{~A}_{4}$, em que I representa o sítio intercamada; M, o sítio octaédrico; T, o sítio tetraédrico; $\mathrm{O}$, oxigênio; e A, ânions. A biotita magmática apresenta a seguinte fórmula:

$\left(\mathrm{K}_{1,509}, \mathrm{Ca}_{0,645}, \mathrm{Na}_{0,007}, \mathrm{Ba}_{0,002}\right)_{2,163}\left(\mathrm{Fe}_{2,775}, \mathrm{Mg}_{1,598}, \mathrm{Ti}_{0,674}, \mathrm{Al}^{\mathrm{VI}}{ }_{0,128}, \mathrm{Li}_{0,082}, \mathrm{Mn}_{0,019},\right)_{5,2}$ ${ }_{76} \mathrm{Si}_{5,219} \mathrm{Al}^{\mathrm{IV}}{ }_{2,780} \mathrm{O}_{20}(\mathrm{OH})_{2}$.

Já as biotitas primárias reequilibradas apresentam a seguinte fórmula média:

$\left(\mathrm{K}_{1,817}, \mathrm{Na}_{0,015}, \mathrm{Ca}_{0,010}, \mathrm{Ba}_{0,004}\right)_{1,846}\left(\mathrm{Fe}_{3,058}, \mathrm{Mg}_{1,745}, \mathrm{Al}_{0,690}^{\mathrm{VI}}, \mathrm{Li}_{0,385}, \mathrm{Ti}_{0,141}, \mathrm{Mn}_{0,030}\right)_{6,09}$ $\mathrm{Si}_{5,441} \mathrm{Al}^{\mathrm{IV}}{ }_{2,558} \mathrm{O}_{20}(\mathrm{OH})_{2}$.

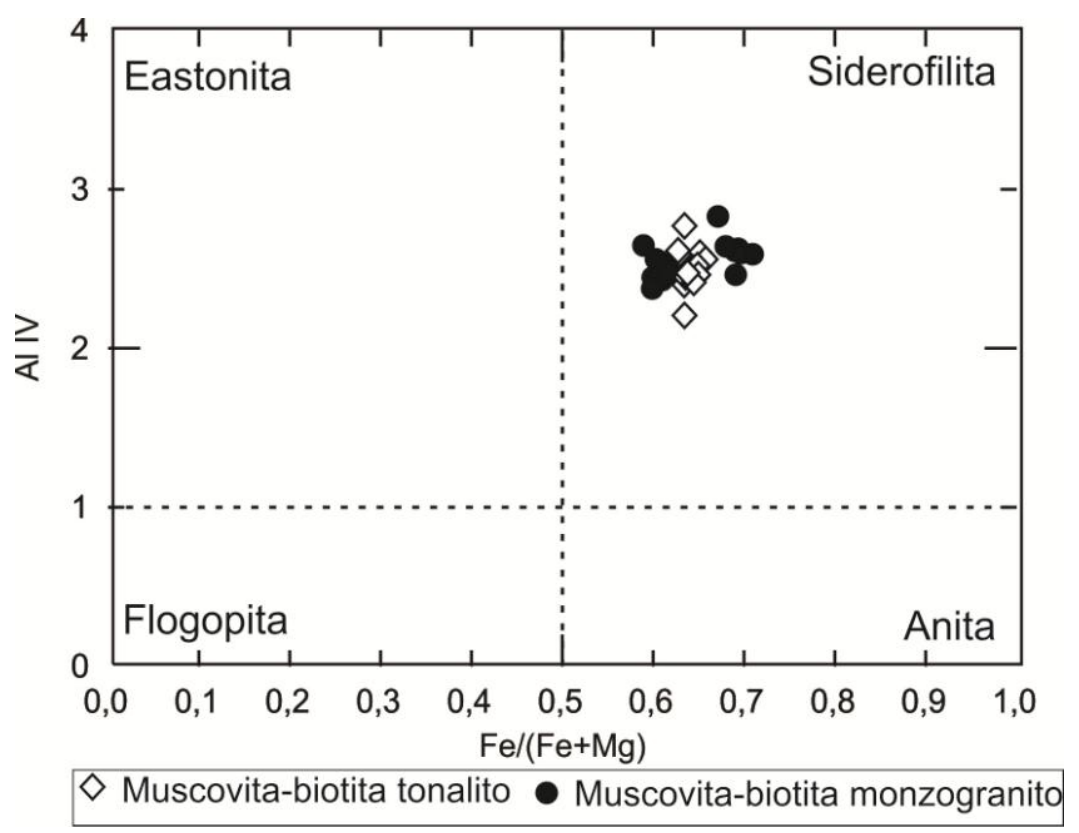

Figura 3.23: Diagrama $\mathrm{Al}^{\mathrm{IV}} v$ s. $\mathrm{Fe} /(\mathrm{Fe}+\mathrm{Mg})$, proposto por Deer et al. (1963), para classificação da biotita estudada.

Nos diagramas de discriminação tectônica propostos por Abdel-Rahman (1994), as análises de biotita de monzogranitos e tonalitos foram plotadas predominantemente no campo de biotita de Suítes Peraluminosas (Fig. 3.24). As relações entre MgO $\mathrm{Al}_{2} \mathrm{O}_{3}, \mathrm{FeO}_{(\mathrm{t})}-\mathrm{Al}_{2} \mathrm{O}_{3}, \mathrm{MgO}-\mathrm{FeO}_{(\mathrm{t})}$ e $\mathrm{MgO}-\mathrm{FeO}_{(\mathrm{t})}-\mathrm{Al}_{2} \mathrm{O}_{3}$ indicam que a biotita tem origem associada a granitos peraluminosos. Algumas amostras caíram no campo dos granitos alcalinos, principalmente no diagrama $\mathrm{MgO}$ - $\mathrm{FeO}(\mathrm{t})$, revelando que essas amostras são um pouco mais enriquecidas em Fe e $\mathrm{Mg}$ em relação às demais.

As variações químicas e substituições nos minerais em estudo foram observadas nos diagramas de correlação entre cátions. O gráfico $\mathrm{R}^{2+} v s$. $\mathrm{R}^{3+}$ (Fig.3.25a) foi usado para testar as substituições no sítio octaédrico, sendo $\mathrm{R}^{2+}\left(\mathrm{Fe}^{2+}+\mathrm{Mn}+\mathrm{Mg}\right)$ e $\mathrm{R}^{3+}\left(\mathrm{Al}^{\mathrm{VI}}\right.$ 
$+\mathrm{Ti}+\mathrm{Cr}$ ) mostrando uma correlação linear negativa. Isso indica que houve substituição entre $\mathrm{R}^{2+}$ e $\mathrm{R}^{3+}$. No entanto, o $\mathrm{Al}^{\mathrm{VI}}$ é o principal responsável pela substituição entre os componentes individuais de $\mathrm{R}^{3+} v s$. $\mathrm{R}^{2+}$. Já a análise individual dos componentes de $\mathrm{R}^{2+} v s . \mathrm{R}^{3+}$ mostra que o Fe e Mg têm uma maior participação nessas substituições.
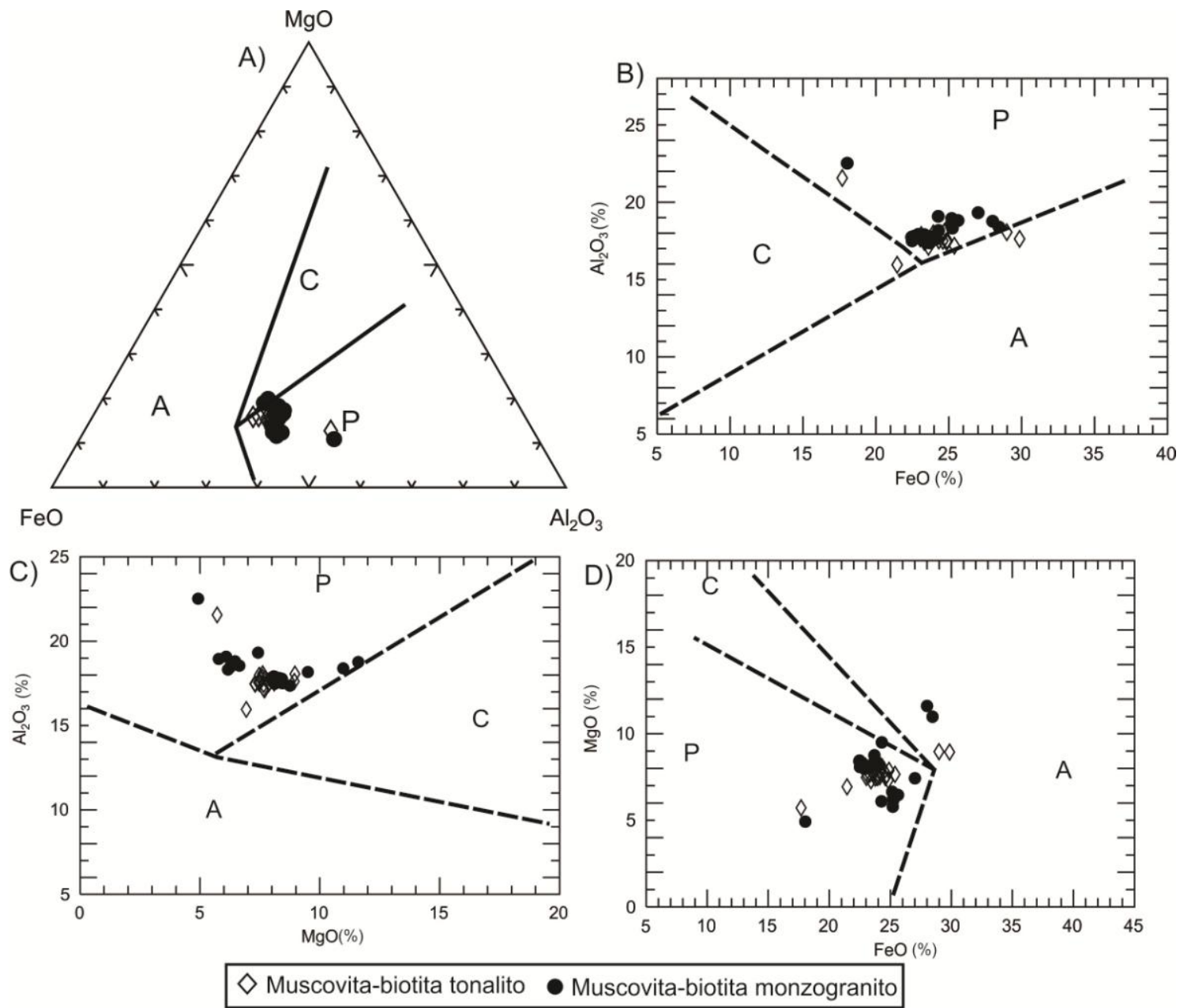

Figura 3.24: Relações entre $\mathrm{MgO}-\mathrm{Al}_{2} \mathrm{O}_{3}, \mathrm{FeO}_{(\mathrm{t})}-\mathrm{Al}_{2} \mathrm{O}_{3}, \mathrm{MgO}-\mathrm{FeO}_{(\mathrm{t})} \mathrm{e} \mathrm{MgO}-\mathrm{FeO}_{(\mathrm{t})}-\mathrm{Al}_{2} \mathrm{O}_{3}$ da biotita dos monzogranitos e tonalitos, no diagrama proposto por Abdel-Rahman (1994) (A=Granitos alcalinos; $\mathrm{C}=$ Granitos cálcio-alcalinos; $\mathrm{P}=$ Granitos peraluminosos).

$\mathrm{O}$ gráfico $\mathrm{Al}^{\mathrm{IV}}$ vs. Fe (Fig.3.25b) mostra uma correlação positiva entre esses elementos. Segundo Feio (2007), isso pode estar ligado ao processo de alteração, em que o conteúdo de $\mathrm{Si}$ aumenta nos cristais de biotita e diminui em $\mathrm{Al}^{\mathrm{IV}}$ no sítio tetraédrico, sendo essa a razão pela qual o $\mathrm{Al}^{\mathrm{VI}}$ substitui o Fe no sítio octaédrico, como mostrado no gráfico $\mathrm{Al}^{\mathrm{VI}} v s$. Fe (Fig.3.25c).

O gráfico Si vs. Fe (Fig.3.25d) apresenta uma correlação linear negativa entre esses elementos. O gráfico Si vs. Ti mostra correlação positiva da biotita reequilibrada, 
evidenciando o seu baixo conteúdo em Ti (Fig.3.25e). A única análise de biotita magmática mostrou elevado teor de Ti em comparação com as outras biotitas. Segundo Dymek (1983), esse alto teor de Ti é devido às altas temperaturas em que a biotita magmática é formada ou quando a biotita é formada com óxidos portadores de Ti, como ilmenita e rutilo. A correlação negativa entre $\mathrm{Al}^{\mathrm{VI}}+\mathrm{Si} v s$. $\mathrm{Al}^{\mathrm{IV}}+\mathrm{Fe}+\mathrm{Mg}$ mostra que houve clara substituição entre esses elementos (Fig.3.25f). É importante salientar que a biotita magmática reequilibrada e magmática se diferenciam, tal qual foi mostrado nos diagramas de substituições, porém, como foi obtida apenas uma análise de biotita magmática, essa variação na composição das micas não pode ser observada claramente.
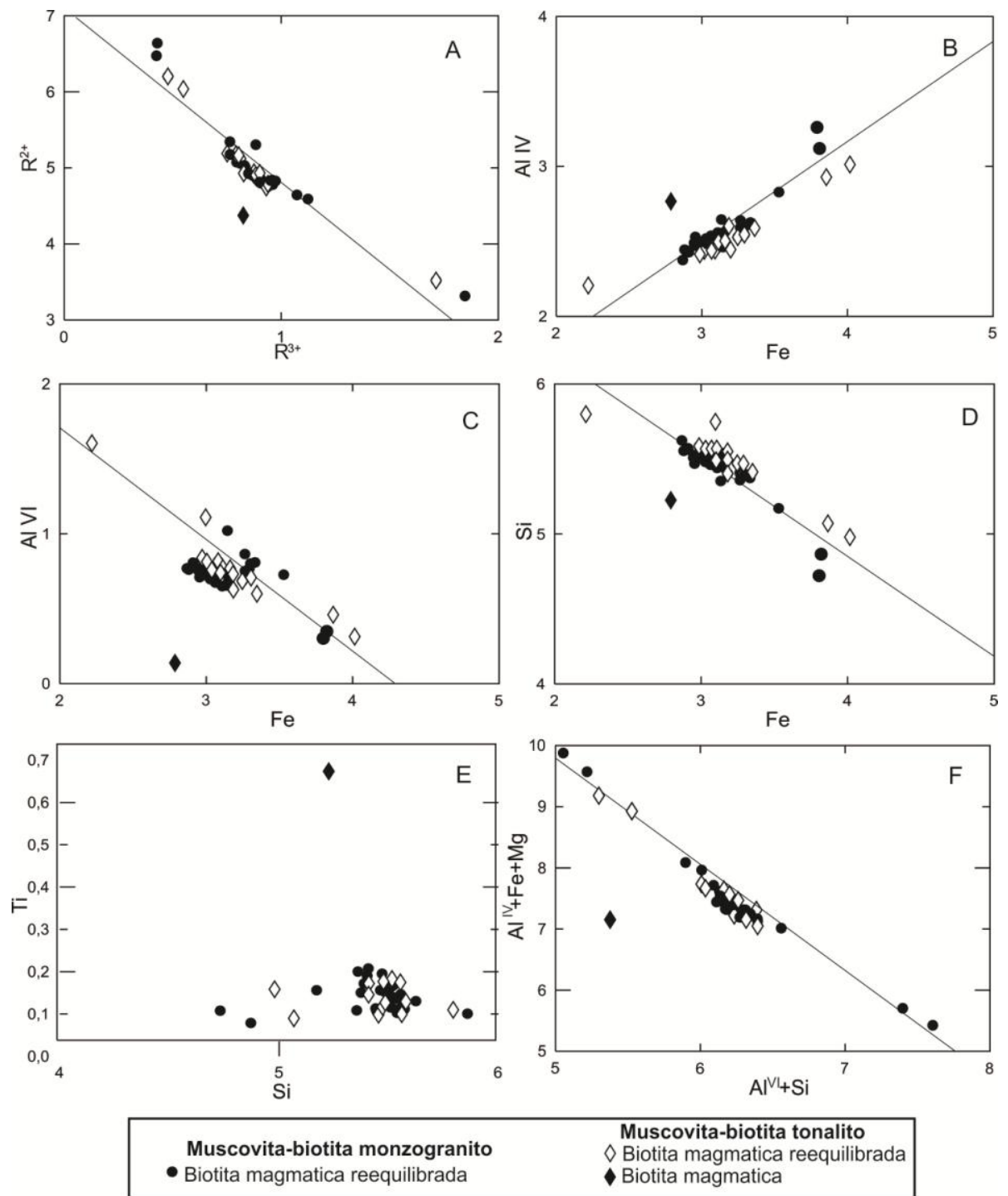

Figura 3.25: Diagramas de variações composicionais das biotitas analisadas para avaliar as substituições dos elementos nas ocupações octaédrica e tetraédrica; a) Diagrama $\mathrm{R}^{2+} v s$. $\mathrm{R}^{3+}$ (a.f.u), mostrando correlação negativa entre os elementos; b) Diagrama $\mathrm{Al}^{\mathrm{IV}} v s$. $\mathrm{Fe}(\mathrm{t})$, mostrando correlação positiva; c) Diagrama $\mathrm{Al}^{\mathrm{VI}} v s$. Fe(t), evidenciando a substituição entre esses elementos; d) Diagrama Si vs. Fe(t), com correlação negativa; e) Diagrama Ti vs. Si, mostrando o baixo conteúdo de Ti entre a biotita magmática e a reequilibrada; f) Diagrama $\mathrm{Al}^{\mathrm{IV}}+\mathrm{Fe}+\mathrm{Mg} v s$. $\mathrm{Al}^{\mathrm{VI}}+\mathrm{Si}$, com correlação negativa. 


\subsubsection{MUSCOVITA}

Foram realizadas 53 análises de muscovita, sendo 29 análises de muscovita pertencente aos albititos e 24 análises de muscovita pertencente ao biotita-muscovita tonalito. A fórmula estrutural foi calculada com base em 22 átomos de oxigênios.

Petrograficamente, são divididas em dois grupos. O primeiro grupo é composto por cristais com hábito euedral a subedral, com tamanho variando de 0,5 a $4 \mathrm{~mm}$. Apresentam lamelas bem desenvolvidas, coexistindo com outros cristais magmáticos. A muscovita com essas características são interpretadas como muscovita magmática ou primária.

Por outro lado, o segundo grupo é formado por cristais com hábito anedral, com lamelas finas. Geralmente são englobados por outros minerais. São denominadas de muscovita secundária (Harrison 1990, Koh \&Yun 1999, Buda et al. 2012, JiHua et al. 2014). Segundo o gráfico proposto por Monier \& Robert (1986), as micas dioctaédricas foram classificadas como muscovita (Fig.3.26).

A muscovita da fácies biotita-muscovita tonalito e dos albititos mostrou-se bem diferente em termos de composição química, apresentando as seguintes composições presente na tabela 3.3.

Tabela 3.3: diferenças composicionais dos cristais de muscovita da fácies biotita-muscovita tonalito e dos albititos.

\begin{tabular}{|c|c|c|}
\hline \multicolumn{3}{|c|}{ Variação composicional das muscovitas analisadas } \\
\hline$\%$ & Albitito & Biotita-muscovita tonalito \\
\hline $\mathrm{Al}_{2} \mathrm{O}_{3}$ & $26,28-33,99 \%$ & $32,58-38,75 \%$ \\
\hline $\mathrm{SiO}_{2}$ & $45,26-48,40 \%$ & $45,43-49,50 \%$ \\
\hline $\mathrm{FeO}$ & $0,20-3,40 \%$ & $0,54-3,689 \%$ \\
\hline $\mathrm{TiO}_{2}$ & $0,0-0,07 \%$ & $0,0-1,153 \%$ \\
\hline $\mathrm{MgO}$ & $0,0-0,93 \%$ & $0,04-1,07 \%$ \\
\hline $\mathrm{MnO}$ & $0,0-0,15 \%$ & $0,0-1,279 \%$ \\
\hline $\mathrm{K}_{2} \mathrm{O}$ & $9,20-10,89 \%$ & $10,11-11,24 \%$ \\
\hline $\mathrm{Na} O$ & $0,26-0,96 \%$ & $0,198-0,69 \%$ \\
\hline $\mathrm{CaO}$ & $0,0-0,17 \%$ & $0,0-0,08 \%$ \\
\hline
\end{tabular}


Alguns autores propõem que o conteúdo de $\mathrm{Ti}$ pode diferenciar a muscovita primária da muscovita secundária (Monier \& Robert 1986, Harrison 1990, Koh \& Yun 1999, Nahodilová et al. 2012, Buda et al. 2012, JiHua et al. 2013). Entretanto, de acordo com os critérios petrográficos estabelecidos, alguns cristais de muscovita magmática que pertencem à fácies biotita-muscovita tonalito obtiveram um baixo teor de Ti. Já os cristais de muscovita considerados petrograficamente secundárias estão de acordo com os critérios químicos, apresentando baixo teor de $\mathrm{TiO}_{2}(0,0-0,07 \%)$.

A muscovita magmática também apresenta alto teor de $\mathrm{Al}, \mathrm{Mg}, \mathrm{Na}$ e conteúdo baixo de Fe e Si (Sun et al. 2002, Buda et al. 2012, Nahodilová et al. 2012, JiHua et al. 2013). Por outro lado, a muscovita secundária apresenta teor inverso desses elementos citados. Tais dados podem ser confirmados por meio dos gráficos propostos por Sun et. al. (2002) (Fig. 3.27).

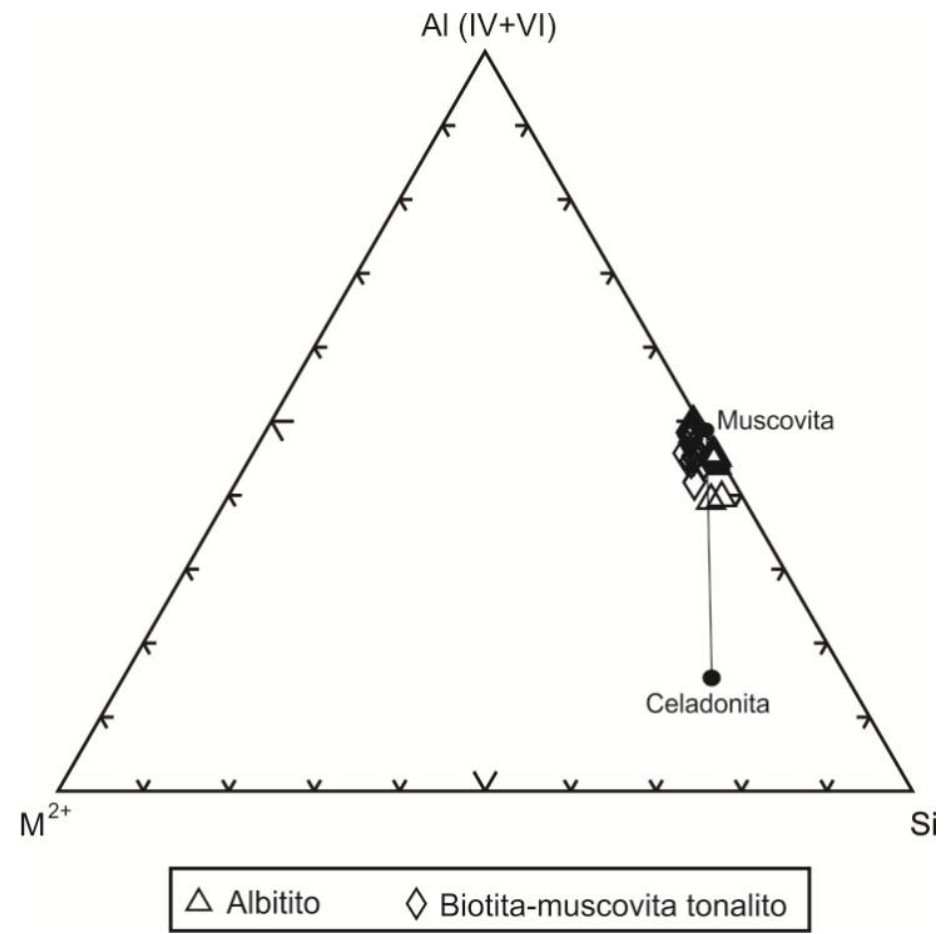

Figura 3.26: Classificação das micas dioctaédricas no diagrama $\mathrm{M}^{2+}-\mathrm{Al}$ - Si, proposto por Monier \& Robert (1986), $\mathrm{M}^{2+}=\mathrm{Fe}^{2+}(\mathrm{t})+\mathrm{Mg}+\mathrm{Mn}$.

Todas as análises de muscovita dos albititos obtiveram baixo teor de Ti, bem menor do que os teores de muscovita secundária da fácies biotita-muscovita tonalito. Devido a isso, o teor de Ti não pode ser usado para diferenciar a muscovita magmática da muscovita secundária nos albititos. 
Observou-se que a muscovita tanto primária quanto secundária não apresenta um critério químico específico para diferenciá-las, sendo que ambas apresentam os mesmos conteúdos de Ti, Al, Mg, Fe, Si e Na.

É importante observar que a muscovita dos albititos caíu no mesmo campo da muscovita secundária da fácies biotita-muscovita tonalito, com exceção do $\mathrm{Na}$ e do $\mathrm{Fe}$, sendo a muscovita dos albititos mais enriquecidas em $\mathrm{Na}$ e mais empobrecidas em $\mathrm{Fe}$, em comparação com a muscovita primária e secundária da fácies biotita-muscovita tonalito.

Os critérios petrográficos não concordaram com os critérios químicos para algumas análises de muscovita, em decorrência de baixos teores de alguns elementos. Por se tratar de rochas altamente evoluídas, alguns elementos como $\mathrm{Ti}, \mathrm{Mg}$ e $\mathrm{Fe}$ apresentam baixos teores e elementos como $\mathrm{Na}$ e $\mathrm{Si}$ apresentam altos teores nessas rochas, devido a isso, os critérios petrográficos nesse estudo são mais confiáveis. Segundo Zane et al. (1999), Miller et al. (1981), cristais que parecem ser texturalmente primários, têm maior teor de $\mathrm{Ti}, \mathrm{Na}, \mathrm{Mg}, \mathrm{Al}$ e possuem teor de $\mathrm{Si}$ e Fe inferior ao teor daqueles que parecem ser secundários. Tais autores ainda afirmam que a composição da rocha total atua como um fator de controle sobre a composição da muscovita. 

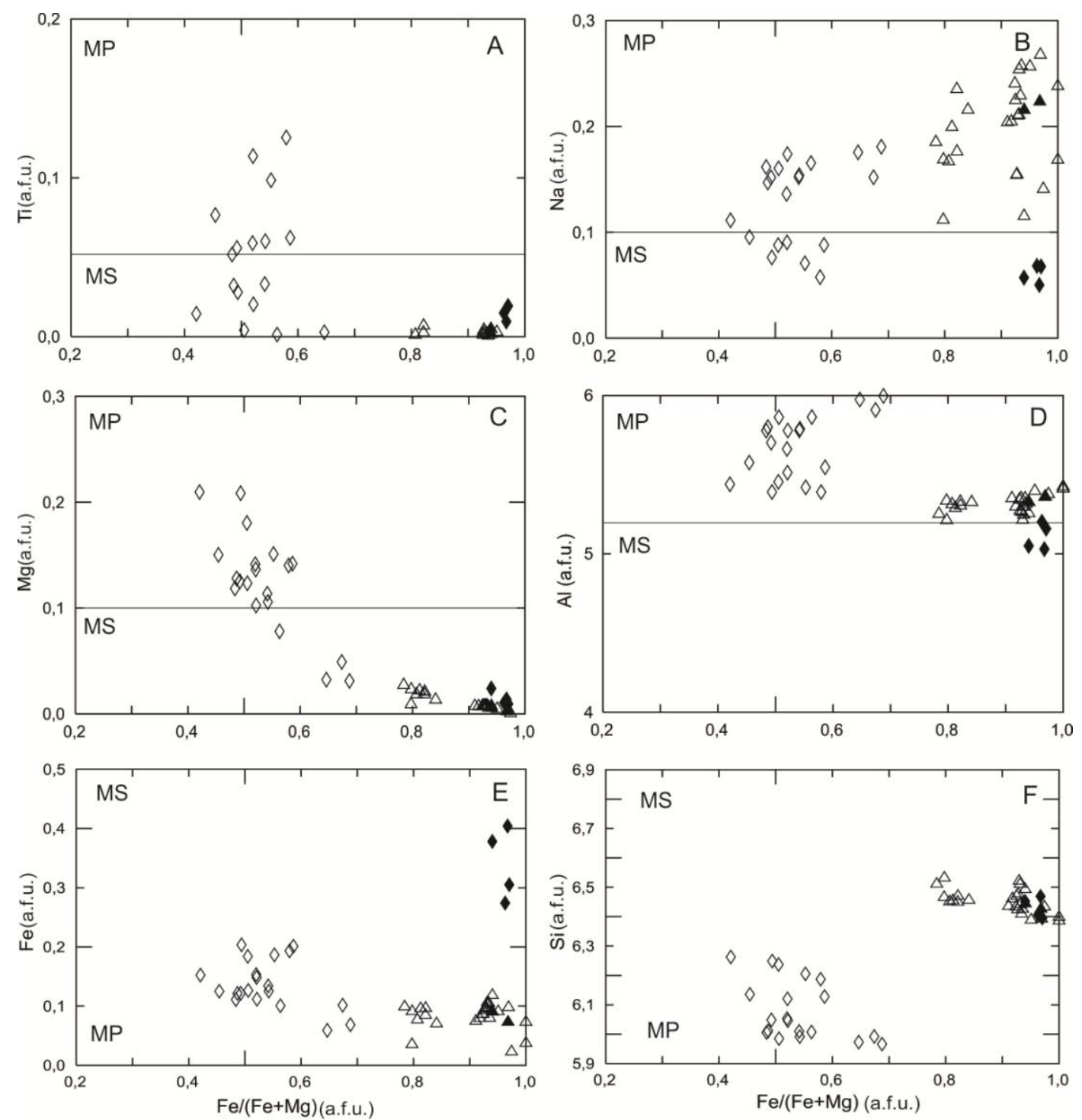

Albitito
$\triangle$ Muscovita Primária
Muscovita Secundária

Biotita-muscovita tonalito

$\diamond$ Muscovita Primária

$\checkmark$ Muscovita Secundária

Figura 3.27: Diagrama de discriminação geoquímica para as muscovitas primárias e secundárias; a) Diagrama Ti vs. $\mathrm{Fe} /(\mathrm{Fe}+\mathrm{Mg})$; b) Diagrama $\mathrm{Na}$ vs. $\mathrm{Fe} /(\mathrm{Fe}+\mathrm{Mg})$; c) Diagrama $\mathrm{Mg}$ vs. $\mathrm{Fe} /(\mathrm{Fe}+\mathrm{Mg})$; d) Diagrama $\mathrm{Al}(\mathrm{t})$ vs. $\mathrm{Fe} /(\mathrm{Fe}+\mathrm{Mg})$, segundo Sun et al. (2002); e) Diagrama $\mathrm{Fe}(\mathrm{t})$ vs. $\mathrm{Fe} /(\mathrm{Fe}+\mathrm{Mg})$; f) Diagrama Si vs. Fe/(Fe+Mg), baseado em Sun et al. (2002).

De acordo com Zhang et al. (2010), muscovita que coexiste com biotita e exibe estrutura metassomática pode ser secundária, mas, na verdade, pode ter sido formada a partir da biotita, por processo de substituição, como mudança de condições físicoquímicas, tornando a biotita instável.

A figura 3.28 mostra a variação composicional dos cristais de muscovita analisados. O diagrama de substituição tetaédrico $\mathrm{Al}^{\mathrm{VI}}$ vs. Si mostra uma correlação negativa entre esses elementos para todas os cristais de muscovita analisados. $\mathrm{O} \mathrm{Al}^{\mathrm{VI}}$ é 
substituído pela Si. Isso mostra que houve um excesso de Si e uma deficiência em Al nas amostras de moscovitas (Viana et al. 2007) (Fig.3.28a).

Já o diagrama $\mathrm{Al}^{\mathrm{VI}}$ vs. Si mostra que as substituições ocorreram de forma diferentes na muscovita dos albititos e da fácies biotita-muscovita tonalito devido a teores diferentes desses elementos. No entanto, a correlação linear negativa ocorre nos diferentes cristais de muscovita, sendo que a Si também substitui o $\mathrm{Al}^{\mathrm{VI}}$ (Fig.3.28b).

$\mathrm{O}$ sítio octaédrico mostra que $\mathrm{Fe}, \mathrm{Mg}$, Mn e Ti são substituídos pelo $\mathrm{Al}^{\mathrm{VI}}$. Mais uma vez, o diagrama mostra o contraste de composição entre a muscovita dos albititos e da fácies biotita-muscovita tonalito nesses elementos (Fig.3.28c).

O diagrama $\mathrm{Fe}^{2+}+\mathrm{Si}$ vs. $\mathrm{Al}(\mathrm{t})$ (Fig.3.28d) revela a importância da substituição de $\mathrm{Al}(\mathrm{t})$ pelo $\mathrm{Fe}$ e $\mathrm{Si}$.
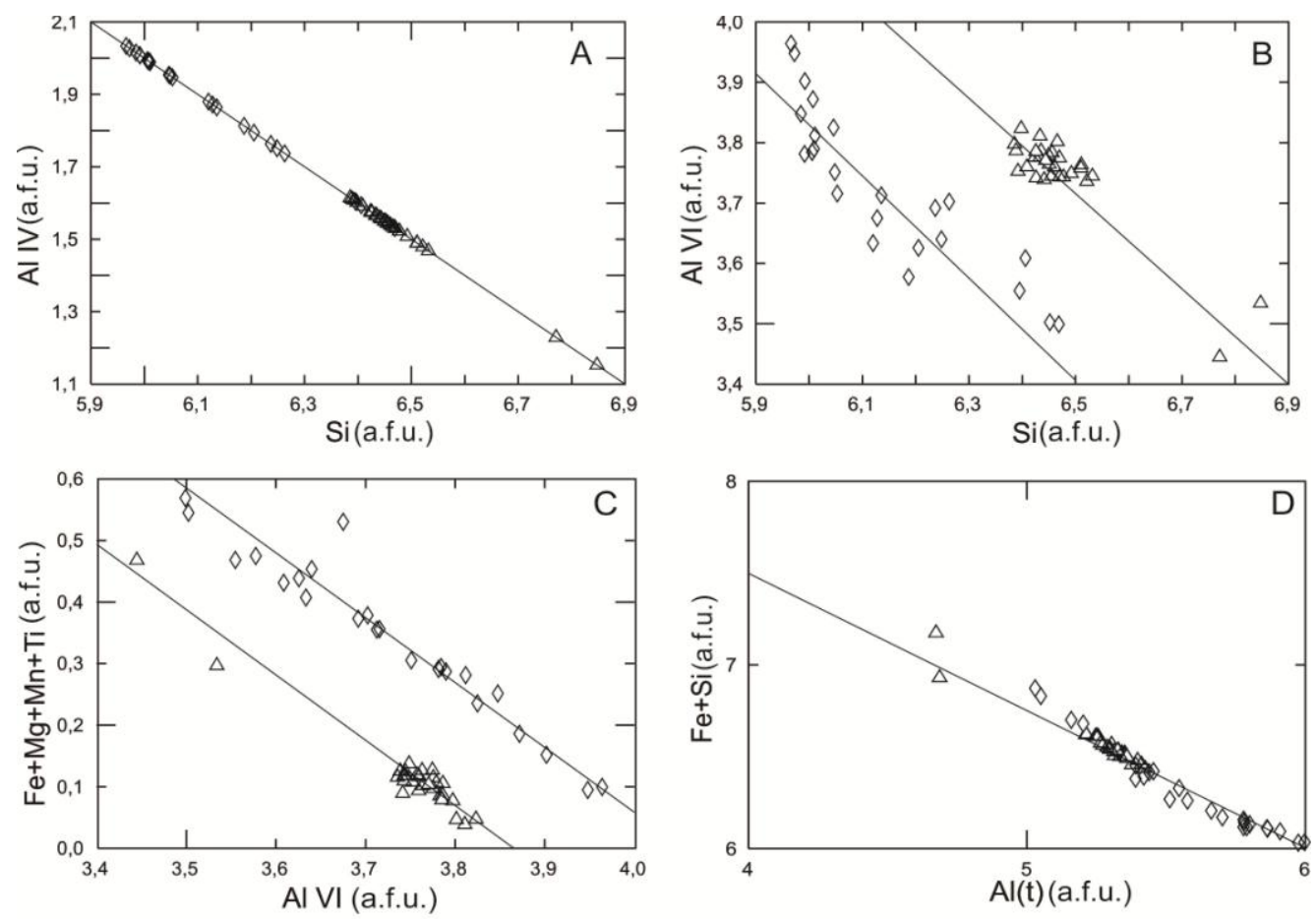

$\triangle$ Albitito $\diamond$ Biotita-muscovita tonalito

Figura 3.28: Variação composicional para as muscovitas mostrando as substituições dos elementos nos sítios octaédrico e tetraédrico; a), b), c) e d) Diagramas de correlação de cátions das muscovitas estudadas. 


\subsubsection{APATITA}

Foram realizadas 24 análises de apatita, sendo 17 análises das apatitas que ocorrem nos albititos do Garimpo Boa Vista e 7 análises das apatitas que ocorrem nos albititos do Garimpo Pelotas. A fórmula estrutural foi calculada com base em 25 átomos de oxigênio.

A estrutura da apatita é formada por um sítio tetraédrico (PO4)-3, que está ligado ao $\mathrm{Ca}$ em dois sítios estruturais diferentes. O primeiro sítio é denominado de Ca1 e o segundo é denominado de $\mathrm{Ca} 2$. O Ca1 é coordenado por nove átomos de oxigênio e o $\mathrm{Ca} 2$ é coordenado por seis átomos de oxigênio e um átomo de flúor, sendo que as principais substituições nesses sítios refletem também mudanças e trocas no sítio tetraédrico, para manutenção do equilíbrio de carga na estrutura (Hogarth 1989).

Mineralogicamente, os cristais de apatita presente nos albititos são anedrais e ocorrem como mineral intersticial, comumente apresentam inclusões de pequenos cristais de albita e são altamente fraturadas.

Os componentes do grupo da apatita pode ser classificados como hidroxiapatita - $\mathrm{Ca}_{5}\left(\mathrm{PO}_{4}\right)_{3} \mathrm{OH}$, fluorapatita - $\mathrm{Ca}_{5}\left(\mathrm{PO}_{4}\right)_{3} \mathrm{~F}$ e cloroapatita $-\mathrm{Ca}_{5}\left(\mathrm{PO}_{4}\right)_{3} \mathrm{Cl}$, assim denominados por causa das concentrações expressivas dos íons em sua estrutura, hidróxido ( $\mathrm{OH}-)$, fluoreto (F-) e cloreto ( $\mathrm{Cl}-)$, respectivamente.

A fórmula química geral da apatita é:

$\mathrm{Ca}_{5}\left(\mathrm{PO}_{4}\right)_{3}(\mathrm{OH}, \mathrm{F}, \mathrm{Cl})$.

Esses minerais são muito comuns em rochas ígneas, sedimentares e metamórficas. Segundo Nagasawa (1970), a apatita é uma fase muito importante no controle da variação do P e dos ETRs em rochas ígneas, fornecendo informações sobre a evolução magmática.

A apatita estudadas apresenta composição de fluorapatita de acordo com o gráfico F-Cl-OH (Fig.3.29a), sendo essa composição típica de apatitas ígneas (Nash 1984). A relação $\mathrm{Cl}$ vs. F mostra que o conteúdo de flúor nas apatitas tanto do garimpo Pelotas quanto do garimpo Boa Vista é maior em relação ao conteúdo de cloro, porém nota-se um leve enriquecimento de F nas apatitas do garimpo Boa Vista, enquanto que algumas amostras de apatita do garimpo Pelotas são mais enriquecidas em $\mathrm{Cl}$ (Fig.3.29b). 


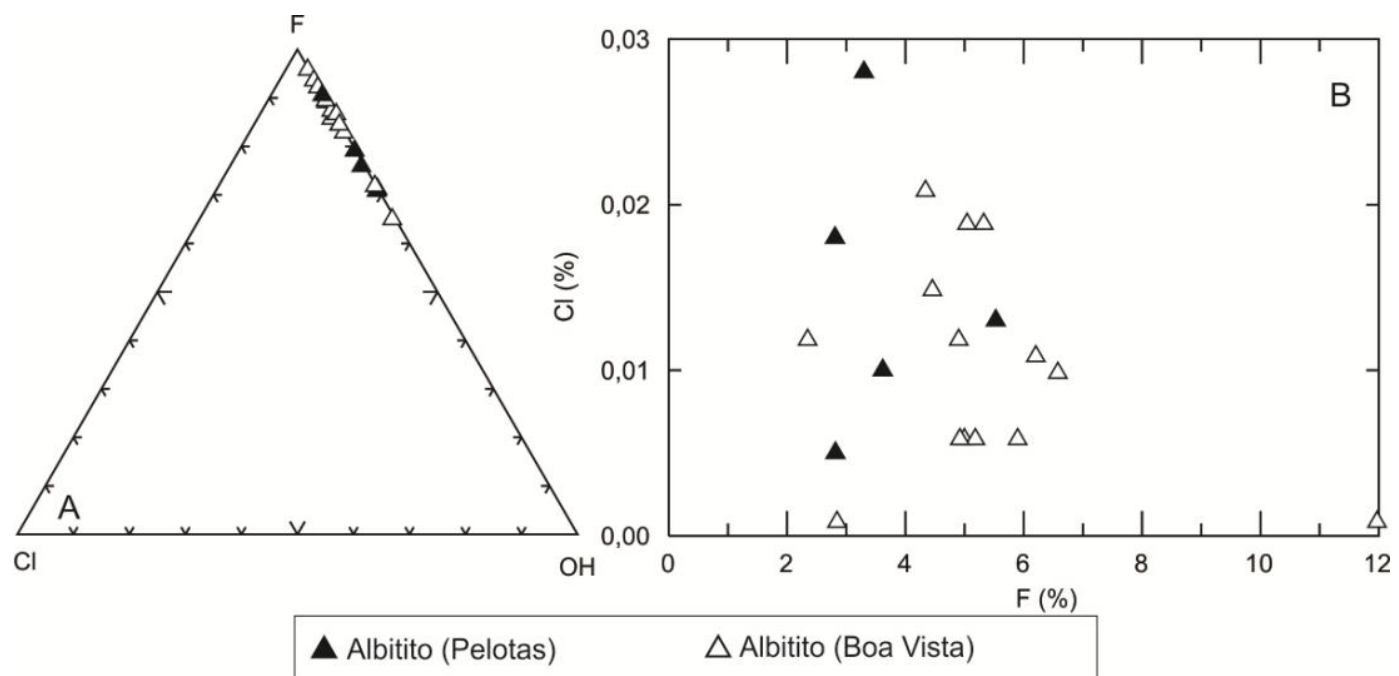

Figura 3.29: a) Composição das apatitas, evidenciando o seu alto conteúdo de $\mathrm{F}$ em relação a $\mathrm{Cl}$ e $\mathrm{OH}$; b) Gráfico mostrando a diferença entre os conteúdo de $\mathrm{F}$ e $\mathrm{Cl}$.

A fórmula química da apatita pode ser expressada da seguinte forma:

$\mathrm{A}_{10}\left(\mathrm{ZO}_{4}\right)_{6} \mathrm{X}_{2}$, onde A: $\mathrm{Ca}^{2+}, \mathrm{Sr}^{2+}, \mathrm{Pb}^{2+}, \mathrm{Ba}^{2+}, \mathrm{Mg}^{2+}, \mathrm{Mn}^{2+}, \mathrm{Fe}^{2+}, \mathrm{Co}^{2+}, \mathrm{Ni}^{2+}, \mathrm{Cd}^{2+}$, $\mathrm{REE}^{3+}, \mathrm{Eu}^{2+}, \mathrm{Ce}^{4+}, \mathrm{Al}^{3+}, \mathrm{Na}^{+} ; \mathrm{Z}: \mathrm{P}^{5+}, \mathrm{Si}^{4+}, \mathrm{S}^{6+}, \mathrm{Al}^{3+}, \mathrm{As}^{5+}, \mathrm{V}^{5+} ; \mathrm{X}: \mathrm{F}^{-}, \mathrm{Cl}^{-}, \mathrm{OH}^{-}, \mathrm{O}_{22}$, $\mathrm{CO}_{3}{ }^{2-}$.

Alguns autores (Sha \& Chappell 1999, Mohammad et al. 2007) mostram que a apatita mostram certas equações de substituições, como:
(1) $\mathrm{ETR}^{3+}+\mathrm{Si}^{4+}=\mathrm{Ca}^{2+} 1 \mathrm{P}^{5+}$;
(2) $\mathrm{ETR}^{3+}+\mathrm{Na}^{+}\left(\mathrm{R}^{+}\right)=2 \mathrm{Ca}^{2+}$;
(3) $\mathrm{Eu}^{2+}=\mathrm{Ca}^{2+}$;
(4) $\mathrm{Na}^{+}+\mathrm{Al}^{3+}=2 \mathrm{Ca}^{2+}$;
(5) $\mathrm{Si}^{+4}=\mathrm{P}^{+4}+\mathrm{Na}^{+}$;
(6) $\mathrm{Mn}^{2+}=\mathrm{Ca}^{2+}$;
(7) $\mathrm{Fe}+=\mathrm{Ca}^{2+}$. 

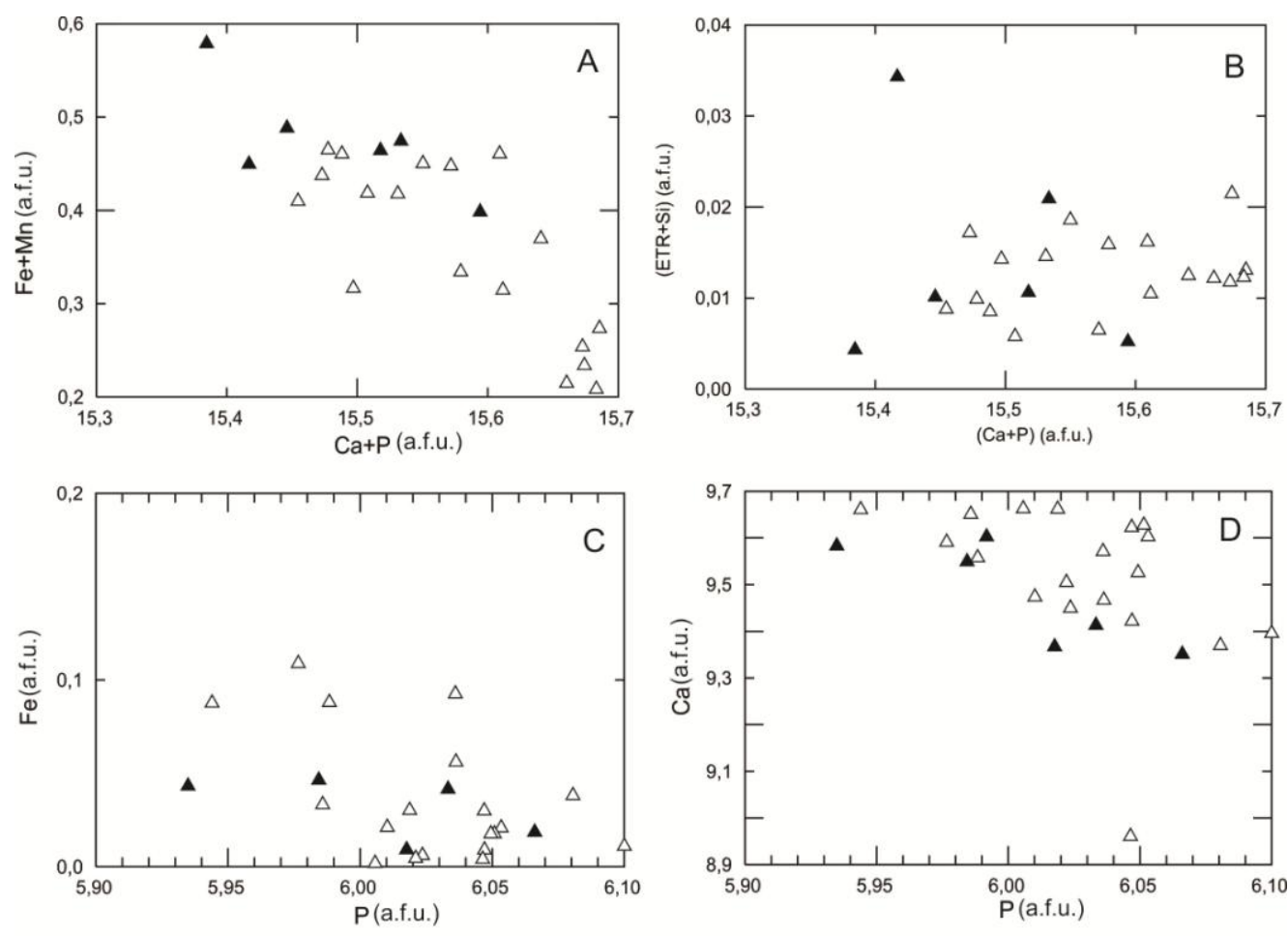

A Albitito (Pelotas)

$\triangle$ Albitito (Boa Vista)

Figura 3.30: Proporções atômicas em apatita a) Fe+Mn vs. Ca+P; b) ETR+Si vs. Ca+P; c) Fe vs. P; d) Ca $v s$. $\mathrm{P}$, mostrando uma leve correlação negativa e positiva entre esses elementos.

Todas as equações acima foram testadas nos cristais de apatita analisadas. Entretanto, foi observado que algumas equações não foram significativas. Isso pode estar ligado ao baixo conteúdo de alguns elementos, como Si, Na, Al e ETR (Teixeira 2002).

As equações 6 e 7 obtiveram um resultado significativo apresentando uma leve correlação negativa. Isso ocorre pelo fato de os conteúdo de Mn e Fe serem mais elevados, principalmente o de Mn (Fig.3.30a,c).

No gráfico Ca vs. $\mathrm{P}$, foi verificada uma correlação negativa mostrando que o $\mathrm{Ca}$ substitui o P (Fig.3.30d). A correlação positiva mostrada no gráfico (ETR+Si) vs. $(\mathrm{Ca}+\mathrm{P})$ evidência o baixo conteúdo em ETR e Si, não obtendo, por isso, uma correlação significativa entre esses elementos (Fig.3.30b). 


\subsection{DISCUSSÃO SOBRE OS DADOS DE LITOGEOQUÍMICA E QUÍMICA MINERAL}

\subsubsection{Comparação entre os Sistemas LCT e NYF da Província Estanifera de Goiás}

A classificação atual da associação granito-pegmatito inclui duas principais famílias petrogenéticas: o sistema LCT (lítio-césio-tântalo) e o sistema NYF (nióbioítrio-flúor). O sistema granito-pegmatito do tipo LCT é enriquecido em $\mathrm{Li}, \mathrm{Rb}, \mathrm{Cs}, \mathrm{Be}$, $\mathrm{Sn}, \mathrm{Nb}><\mathrm{Ta}$, B, P e F, enquanto Ti, Zr, Y e REE são em grande parte muito baixo, são normalmente relacionados a granitos peraluminosos (Černý 1991).

Por outro lado, o sistema granito-pegmatito do tipo NYF enriquecido em $\mathrm{Nb}>\mathrm{Ta}$, Y, REE, Sc, Ti, Zr, Be, Th, U, F é associado a suítes intraplaca, bem como a granitos metaluminosos e peralcalinos, e é formado em ambiente extensional (Černý 1991, Martin et. al. 2005).

Existe a ocorrência de um terceiro tipo de associação granito-pegmatito com uma assinatura mista entre o sistema LCT e NYF, apresentando um compartilhamento de características geoquímicas e mineralógicas desses sistemas (Novák et al. 2012, Pieczka et. al. 2013).

Várias possibilidades foram propostas para a origem dos sistemas de granitopegmatito misto (Černý 1991, Černý \& Ercit 2005). A primeira possibilidade revela que um magma NYF primitivo da crosta empobrecida pode ser contaminado por digestão de litologias supracrustais não empobrecidas. A segunda possibilidade mostra que o protólito crustal pode ter sido apenas parcialmente esgotado. E a terceira possibilidade apontaque a anatexia pode ter afetado uma faixa mista de protólitos empobrecidos e não empobrecidos.

A mineralogia típica do sistema LCT é representada por Li-turmalina, Li-mica, cassiterita, columbita, tantalita, elbaíta-liddicoatita, polucita, espodumênio, Cs-berilo e fosfatos. Por outro lado, o sistema NYF é caracterizado por apresentar Ce-allanita, Cemonazita, Y-xenotima, cassiterita, fluorita, topázio, minerais do grupo da columbita, ixiolita, ferrowogdginita, ilmenita e titanita.

A Província Estanífera de Goiás (PEG) apresenta granitos do tipo LCT (Suíte Aurumina) e granitos do tipo NYF (granito intraplaca). Segundo Botelho \& Moura (1998), os granitos intraplaca da PEG são enriquecidos em F, Sn, Rb, Y, Th, Nb, Ga e REE, e são metaluminosos a peralcalinos, com altas razões de Nb/Ta e F/Li.Assim, são 
classificados como uma associação de granito-pegmatito fértil do tipo NYF de Cerny (1991).

Já os granitos pertencentes à Suíte Aurumina têm características típicas do sistema LCT, apresentando altas razões de Ta/Nb. São ricos em Li, Rb, Cs, Ga, Sn, Ta. Entretanto, apresentam baixos valores de Ti, Zr, Y e ETR e baixas razões de F/Li e F/Cs (Pereira 2002).

Os dados de geoquímica e química mineral apresentados neste trabalho mostram que os tonalitos, granitos e albititos possuem características do sistema LCT. No entanto, foi observado que os albititos que são mineralizados em estanho apresentam alto teor de $\mathrm{Cs}, \mathrm{Rb}, \mathrm{Be}, \mathrm{Ga}, \mathrm{Sn}, \mathrm{Nb}<\mathrm{Ta}, \mathrm{P}$ e baixos teores de Ti, $\mathrm{Zr}$, Y e ETR. O Li, F e B não foram analisados, porém foi constatado, por meio da análise petrográfica, que a turmalina ocorria em algumas amostras de granito, mas apenas como mineral acessório. A presença de turmalina nessas rochas, mesmo em quantidades pequenas, é uma evidência de sistema rico em Boro.

Dados de química mineral da cassiterita que ocorrem essencialmente nos albititos dos garimpos Pelotas e Boa Vista revelam que o conteúdo de Ta predomina sobre o conteúdo de $\mathrm{Nb}$, mostrando que o Ta, assim como o $\mathrm{Sn}$, é um elemento bastante importante na cassiterita. Comparando as cassiteritas analisadas neste trabalho com as cassiteritas da Suíte Intraplaca (Botelho 1992) e com as cassiteritas da Suíte Aurumina (Pereira 2002), verificou-se que as cassiteritas estudadas apresentam semelhança em relação às cassiteritas da Suíte Aurumina, de Pereira (2002), apesar de o teor de Ta destas últimas chegar a 5\%, enquanto o teor de Ta das cassiteritas deste estudo chega a quase $1,5 \%$. Entretanto, o teor de Ta ainda é superior ao daquelas da Suíte Intraplaca (Fig.3.31). 


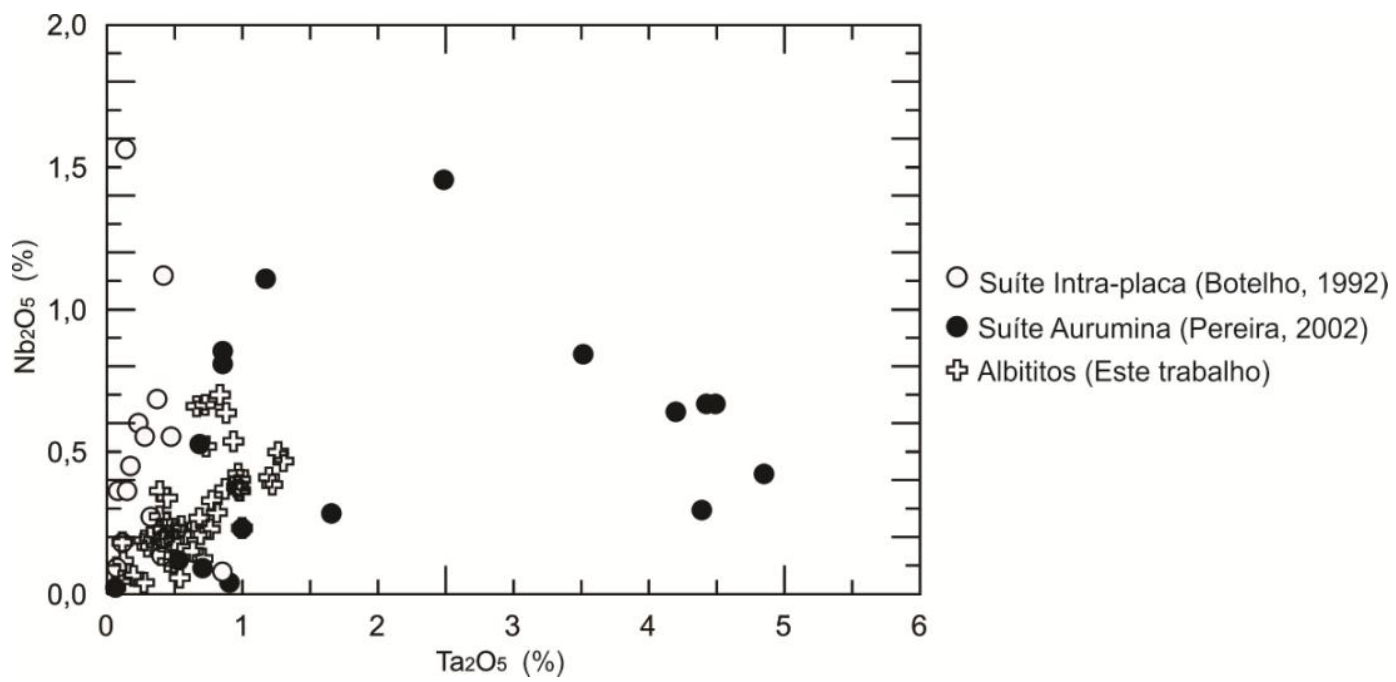

Figura 3.31: Relação $\mathrm{Ta}_{2} \mathrm{O}_{5}$ vs. $\mathrm{Nb}_{2} \mathrm{O}_{5}$ das cassiteritas dos albititos em comparação com as cassiteritas das rochas das Suítes Auruminae Intraplaca.

A cassiterita presente nos granitos intraplaca ocorre principalmente em granitos greisenizados, greisens de fraturas, zonas albitizadas e zonas de contato entre granitomilonito greisenizado. Na Suíte Aurumina, a cassiterita ocorre em pegmatitos, granitos greisenizados, greisens e albititos de origem magmática.

\subsection{ISOTOPOS DE OXIGÊNIO}

A aplicação de isótopos estáveis tem se concentrado na identificação das fontes da fase fluida, nos processos de interação fluido-rocha e na determinação de temperaturas aparentes baseadas em fracionamentos ${ }^{18} \mathrm{O} /{ }^{16} \mathrm{O}$. Segundo Taylor \& Sheppard (1986), Eiler (2001), isótopos de oxigênio têm sido amplamente utilizados em conjunto com outras informações geoquímicas e petrológicas para identificar situações geologicamente favoráveis que mostram fenômenos magmáticos importantes, incluindo a geração, a evolução e a cristalização do magma.

Análises de isótopos de oxigênio foram realizadas em pares de albita $\left(\delta^{18} \mathrm{O}_{\text {VSMOW }}=6,7\right.$ a $\left.9,3 \% 0 ; n=5\right)$ e cassiterita $\left(\delta^{18} \mathrm{O}_{\text {VSMOW }}=5,3\right.$ a $\left.6,6 \% ; n=4\right)$ interpretados petrograficamente como estando em paragênese, dos garimpos Boa Vista e Pelotas (Tab.3.3). As análises foram realizadas no laboratório do Geological Sciences and Geological Engineering department, da Queen's University, em Kingston, no Canadá. 
O estudo geotermométrico foi baseado nos pares em equilíbrio isotópico de albita-cassiterita. Os cálculos para os intervalos de temperatura foram elaborados com base na curva de fracionamento regida pela equação:

1- $1000 \ln \alpha=\mathrm{A} \times 10^{6} / \mathrm{T}^{2}+\mathrm{B} \times 10^{3} / \mathrm{T}+\mathrm{C}$ (Zhenget al.1991), para temperaturas entre $0 \mathrm{a}$ $1200^{\circ} \mathrm{C}$.

Os parâmetros A, B e C na equação 1 são constantes numéricas determinadas experimentalmente por Zheng et al. (1991), sendo $A=3,68, B=-9,58$ e $C=2,00$ para o sistema cassiterita-água.

Para o sistema albita-água, foi usada a equação:

2- $1000 \ln \alpha=\mathrm{A}+\mathrm{B} / \mathrm{T}^{2}$ (Bottinga \& Javoy 1973).

Em que $A=-3,70$ e $B=3,13$,para temperaturas entre 500 e $800^{\circ} \mathrm{C}$.

Tabela 3.4: Composição isotópica dos pares de albita-cassiterita; valores calculados para os intervalos de temperaturas de cristalização; e intervalo de composição isotópica do fluido magmático $\left(\delta^{18} \mathrm{O} \mathrm{H}_{2} \mathrm{O}\right)$.

\begin{tabular}{|c|c|c|c|c|c|}
\hline \multirow[b]{2}{*}{ Amostra } & \multirow[b]{2}{*}{ Garimpo } & \multicolumn{2}{|c|}{ Mineral (V-SMOW) } & \multirow{2}{*}{$\begin{array}{c}\text { Temperatura } \\
\left({ }^{\circ} \mathrm{C}\right)\end{array}$} & \multirow{2}{*}{$\begin{array}{c}\text { Composição } \\
\text { Isotópica do } \\
\text { fluido }\left(\delta^{18} \mathrm{O}\right. \\
\mathrm{H}_{2} \mathrm{O} \% \text { oo }\end{array}$} \\
\hline & & $\begin{array}{l}\text { Albita } \\
\left(\delta^{18} \mathrm{O} \% \text { }\right)\end{array}$ & $\begin{array}{c}\text { Cassiterita } \\
\left(\delta^{18} \mathrm{O} \% \mathrm{o}\right)\end{array}$ & & \\
\hline FPS-8-8-35,20 & Pelotas & 9,3 & 5,3 & $653^{\circ} \mathrm{C}$ & 9,35 \\
\hline FPS-2-8-31,26 & Pelotas & 6,7 & 6,6 & $1319^{\circ} \mathrm{C}$ & 9,17 \\
\hline MA-10 & Boa Vista & 7,7 & & $\begin{array}{c}800^{\circ} \mathrm{C} \\
\text { (estimada) }\end{array}$ & 8,68 \\
\hline PA-1D & Boa Vista & 7,8 & 6,0 & $943^{\circ} \mathrm{C}$ & 9,39 \\
\hline PA-01-DII & Boa Vista & 7,9 & 6,5 & $1016^{\circ} \mathrm{C}$ & 9,72 \\
\hline
\end{tabular}

O intervalo geotermométrico obtido por meio do par albita-cassiterita foi de 653 a $1319^{\circ} \mathrm{C}$ para os albititos do garimpo Pelotas, porém notou-se que a temperatura obtida pela amostra FPS-2-8-31,26 foi muito elevada. Isso se deve provavelmente aos valores próximos da composição isotópica da albita e cassiterita, sendo que a diferença entre os valores $\left(\Delta_{\mathrm{xy}}\right)$ dos dois minerais foi de apenas $0,1 \%$. Com isso, ocorreu imprecisão no resultado da temperatura calculada. Segundo Matsuhisa et al. (1978), incertezas nos resultados de temperaturas podem ocorrer quando o valor de $\left(\Delta_{\mathrm{xy}}\right)$ for $\pm 0,1 \%$, de acordo 
com dados experimentais. Isso também foi observado por Johnson et al. (1999) em análise de isótopo de oxigênio em pares minerais em que os valores da composição isotópica $\left(\Delta_{\mathrm{xy}}\right)$ foram muito próximos. Esse valor de $1319^{\circ} \mathrm{C}$ será, portanto, desconsiderado no presente trabalho. Para os albititos do garimpo Boa Vista, foi obtido um intervalo de temperatura entre 943 e $1016^{\circ} \mathrm{C}$.

Para o cálculo da composição isotópica do fluido $\delta^{18} \mathrm{O}$, foi usada a relação:

3- $\delta^{18} \mathrm{O}($ mineral $)-\delta^{18} \mathrm{O}\left(\mathrm{H}_{2} \mathrm{O}\right)=1000 \ln \alpha$.

$\mathrm{O}$ valor de $\delta^{18} \mathrm{O}$ (mineral) corresponde à composição isotópica de albita ou cassiterita, e a temperatura usada para chegar ao resultado de $1000 \ln \alpha$ foi obtida por meio de cada par mineral de albita-cassiterita.

A composição isotópica dos fluidos do garimpo Pelotas varia de 9,17 a 9,35\%o e do garimpo Boa Vista varia de 8,68 a 9,72\%o (Fig. 3.32). Já na amostra MA-10, foi obtida apenas a composição isotópica da albita. Para calcular a composição isotópica do fluido, foi usada a equação $1000 \ln \alpha=\mathrm{A}+\mathrm{B} / \mathrm{T}^{2}$ (Bottinga \& Javoy 1973), para temperatura entre 500 e $800^{\circ} \mathrm{C}$. Assim, foi considerada a temperatura de $800^{\circ} \mathrm{C}$, uma vez que é próxima das temperaturas obtidas pelos pares minerais de outras amostras.

Foi observado que, à medida que atemperatura aumenta, o valor da composição isotópica do fluido também aumenta. Esses dados estão de acordo com a composição de fluidos de origem magmática. Segundo Taylor Jr. (1974), fluidos de derivação magmática apresentam um típico intervalo isotópico $\delta^{18} \mathrm{O}$ entre 5,5 e 10,0\%o. 


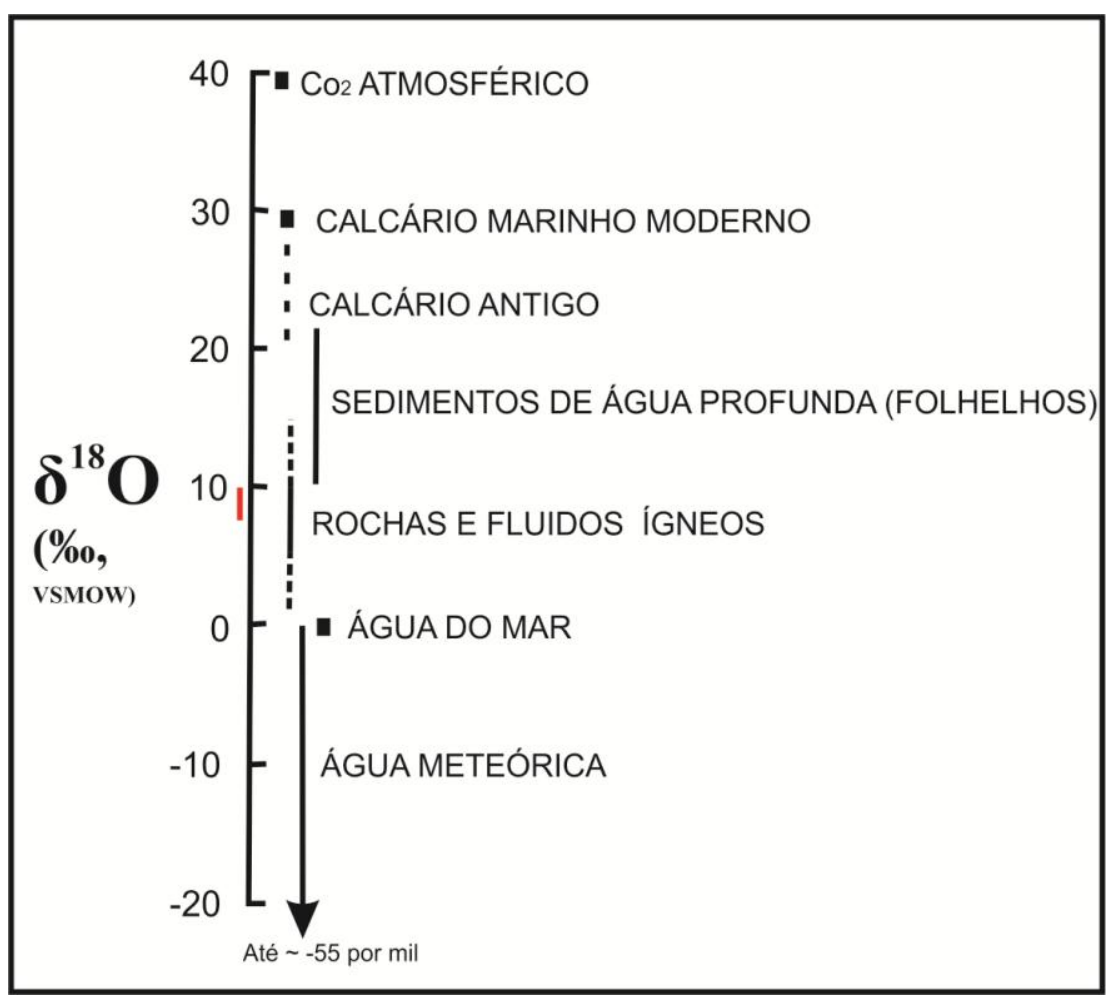

Figura 3.32: Valores de $\delta^{18} \mathrm{O}(8,68$ a 9,72\%o) calculados para os fluidos em equilíbrio isotópico (linha vermelha) em comparação com os valores comuns dos principais reservatórios (adaptado de Campbell \& Larson 1998).

\subsubsection{INTERPRETAÇÃO DOS DADOS DE ISÓTOPOS DE OXIGÊNIO}

Os estudos de isótopos de oxigênio indicaram assinaturas isotópicas para os fluidos em equilíbrio com albita e cassiterita nos albititos dos garimpos Pelotas e Boa Vista condizentes com fluidos de origem magmática. As temperaturas obtidas foram de 653 a $1319^{\circ} \mathrm{C}$ para os albititos do garimpo Pelotas. No entanto, como pode ter ocorrido um erro analítico em relação ao resultado de temperatura muito elevada obtido por uma das amostras, admitiu-se que a temperatura em que o fluido coexistiu com os cristais de albita e cassiterita foi de $653^{\circ} \mathrm{C}$. Para os albititos do garimpo Boa Vista, a temperatura de precipitação da albita e da cassiterita ocorreu no intervalo de 800 a $1016^{\circ} \mathrm{C}$.

Segundo Taylor et al. (1974), pode-se calcular a composição isotópica do fluido que coexiste com vários minerais ígneos em temperaturas magmáticas. Na medida em que existem magmas apenas ao longo de um intervalo restrito de temperatura de cerca de 700 a $1.100{ }^{\circ} \mathrm{C}$, e porque a maioria das rochas vulcânicas e plutônicas geralmente têmvalores uniformes de $\delta^{18} \mathrm{O}$ entre 5,5 e 10,0 e valores de $\delta \mathrm{D}$ entre-50 e -85 , o intervalo isotópico para o fluidomagmático é muito mais restrito do que o intervalo para o fluido metamórfico. 
De acordo com O’Neil (1977), as rochas graníticas apresentam faixas mais amplas de composições isotópicas, tendo como base diferenças de composições mineralógicas e geoquímicas, permitindo uma separação em tipos com fontes sedimentares (tipo-S) e ígneas (tipo-I). Em alguns casos, essa separação é confirmada por dados isotópicos.

Os granitos tipo-S apresentam $\delta^{18} \mathrm{O}$ V-SMOW de $+10,4 \mathrm{a}+12,5 \%$. Aqueles valores mais elevados são tidos como resultados de participação de rochas sedimentares ou metamórficas nas gêneses dos granitos.

Informações petrográficas e geoquímicas são importantes na interpretação do comportamento isotópico por meio da história de cristalização do magma (Kalamarides 1986). Valores altos de $\delta^{18} \mathrm{O}$ nos minerais de albita e cassiterita são evidências de um magma evoluído. Segundo Eiler (2001), o aumento de $\mathrm{Na}_{2} \mathrm{O}$ no fundido também aumenta linearmente os valores de $\delta^{18} \mathrm{O}$, e, em fundido com conteúdo empobrecido em $\mathrm{MgO}$, os valores de $\delta^{18} \mathrm{O}$ também são baixos. O aumento do conteúdo de albita no fundido eleva os valores de $\delta^{18} \mathrm{O} . \mathrm{O}$ grau de enriquecimento de ${ }^{18} \mathrm{O}$ em rochas magmáticas é maior com o aumento do conteúdo de $\mathrm{SiO}_{2}$, pois $\mathrm{SiO}_{2}$ é enriquecida em ${ }^{18} \mathrm{O}$, o que é consistente com cristalização fracionada em sistema fechado (Zhao 2001, Harris 1999).

Características petrológicas e geoquímicas indicam que os albititos passaram por várias etapas de cristalização fracionada. Isso também foi confirmado pelos dados isotópicos de oxigênio.

Kalamarides (1986), constatou que temperaturas muito elevadas são comumente reportadas a corpos ígneos plutônicos que cristalizaram em várias etapas. Dessa forma, o comportamento de ${ }^{18} \mathrm{O}$ durante a cristalização pode ser visto apenas como um produto final; portanto, os isótopos de oxigênio permaneceram como um sistema fechado durante a extrema cristalização fracionada do magma.

Assim, as altas temperaturas obtidas a partir dos pares de minerais em equilíbrio isotópico registram as temperaturas de fechamento de oxigênio em que foram formadas. A temperatura de fechamento do sistema isotópico dos pares minerais de albitacassiterita foi muito elevada, revelando que o magma que deu origem aos albititos passou por vários processos de cristalização fracionada e que o líquido residual fortemente sódico e rico em fósforo começou a cristalizar a uma temperatura muito elevada. 
Os valores de composição isotópica de oxigênio obtidos a partir dos pares de albita-cassiterita são maiores do que os valores típicos do manto (MORB $=5,75 \pm 2 \%$; Troll et al. 2012). Isso confirma mais uma vez que o magma que originou os albititos passou por vários processos de cristalização fracionada e, devido a esse fato, houve o enriquecimento em ${ }^{18} \mathrm{O}$ no magma residual.

\subsection{DATAÇÃO ${ }^{40} \mathrm{Ar} /{ }^{39} \mathrm{Ar}$ EM MUSCOVITA}

A análise geocronológica ${ }^{40} \mathrm{Ar} /{ }^{39} \mathrm{Ar}$ em muscovita foi realizada apenas para os albititos do garimpo Boa Vista. Os albititos desse garimpo são caracterizados por apresentar maior quantidade de muscovita, interpretada neste trabalho como sendo de origem magmática, com lamelas bem desenvolvidas e com hábito euedral. As lamelas de muscovita analisadas correspondem à amostra HER-01.

O procedimento analítico foi realizado da seguinte forma: foram aplicados 23steps de baixa e alta temperatura em micas, as quais foram irradiadas por cerca de 40 horas em um reator nuclear do tipo McMaster. Foi empregado um laser de íon específico (Ar) de 8w tipo Lexel 3500, um espectrômetro de massa do tipo MAP 216, com fonte Signer Baur, e um multicoletor de elétrons.

As medidas dos isótopos de argônio são normalizadas à razão atmosférica ${ }^{40} \mathrm{Ar}^{136} \mathrm{Ar}$, usando as razões propostas por Roddick (1983). As idades e os erros foram corrigidos utilizando as fórmulas propostas por Steiger \& Jäger (1977) e Dalrymple et al. (1981). As idades e erros apresentados representam uma precisão analítica de $2 \sigma$ ou 0,5\%, adequados ao espectro de variação para forma de platô (McDougall \& Harrison 1988). As idades obtidas foram referenciadas para o padrão $\mathrm{H}_{\mathrm{b} 3} \mathrm{Gr}$ (hornblenda) em 1072 Ma (Roddick 1983).

De acordo com o gráfico mostrado na Fig.3.33, o primeiro $1 \%$ de ${ }^{39} \mathrm{Ar}$ liberado

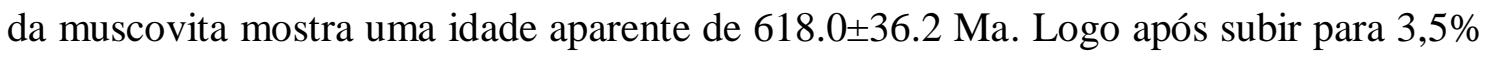
de ${ }^{39} \mathrm{Ar}$ liberado, a idade aparente rapidamente sobe para 1901.2 \pm 29.8 Ma. Isso demonstra que a idade aparente concorda com as etapa de baixa e alta temperatura, pois à medida que o ${ }^{39} \mathrm{Ar}$ é liberado da muscovita e a temperatura de aquecimento e desgaseificação aumenta, ocorre também o aumento da razão ${ }^{40} \mathrm{Ar} * /{ }^{39} \mathrm{~K}$ e da idade aparente.

Foram realizados 23 incrementos de temperaturas (steps), sendo que os primeiros 10 incrementos de temperatura com $47 \%$ de ${ }^{39} \mathrm{Ar}$ liberado não atingiram a 
idade platô de resfriamento da muscovita. Nesse intervalo, ocorreu algum evento provocando uma perturbação e uma posterior liberação de ${ }^{39} \mathrm{Ar}$.

Os critérios utilizados para definir a idade platô são: (1) a região platô de espectro de idade deve incluir, pelo menos, $70 \%$ do total de ${ }^{39} \mathrm{Ar}$ liberado; (2) deve haver, pelo menos, 3 etapas no platô; e (3) a fração de idades individuais devem concordar com a idade "integrada" do segmento platô (Corsini et al. 1997). Apesar de apenas $47,8 \%$ de ${ }^{39} \mathrm{Ar}$ ter sido liberado da muscovita e 10 etapas de incremento de temperatura conter a informação necessária acerca da idade de resfriamento da muscovita, a idade parece confiável.

Quando ocorreu a liberação inicial de $47 \%$ de ${ }^{39} \mathrm{Ar}$ de muscovita, houve a primeira idade aparente significativa de $1984,0 \pm 16,0$ Ma. A partir desse ponto até a etapa completa de fusão do cristal, houve a liberação de $47,8 \%$ de ${ }^{39} \mathrm{Ar}$, obtendo uma

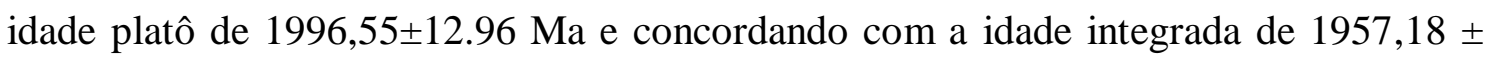

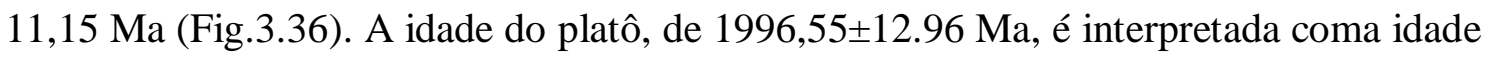
de resfriamento da muscovita e, portanto, como a idade de cristalização do albitito. 
Rochas albitizadas e albititos relacionados a mineralizações de estanho da Província Estanífera de Goiás: caracterização petrológica e gênese.

Tabela 3.5: Dados analíticos 40Ar/39Ar para os albititos do garimpo Boa Vista.

\begin{tabular}{|c|c|c|c|c|c|c|c|}
\hline $\begin{array}{c}\text { Energia } \\
(\%)\end{array}$ & $36 \mathrm{Ar} / 40 \mathrm{Ar}$ & $39 \mathrm{Ar} / 40 \mathrm{Ar}$ & $\mathrm{Ca} / \mathrm{K}$ & $\% 40 \mathrm{Ar}$ atm & $\% 39 \mathrm{Ar}$ & $40 \mathrm{Ar}^{*} / 39 \mathrm{~K}$ & Idade (Ma) \\
\hline \multicolumn{8}{|c|}{ Amostra: HER-01 J:0.008031 \pm 0.000060} \\
\hline 3.00 & $0.0017 \pm 0.0004$ & $0.0210 \pm 0.0009$ & 0.010 & 50.67 & 0.11 & $23.37 \pm 6.39$ & $310.3 \pm 78.0$ \\
\hline 4.00 & $0.0006 \pm 0.0001$ & $0.0156 \pm 0.0004$ & 0.010 & 20.57 & 0.20 & $50.87 \pm 3.52$ & $618.0 \pm 36.2$ \\
\hline 4.50 & $0.0002 \pm 0.0001$ & $0.0174 \pm 0.0005$ & 0.010 & 8.74 & 0.22 & $52.20 \pm 3.39$ & $631.6 \pm 34.6$ \\
\hline 5.00 & $0.0000 \pm 0.0001$ & $0.0169 \pm 0.0003$ & 0.010 & 0.53 & 0.30 & $58.80 \pm 2.63$ & $697.8 \pm 25.8$ \\
\hline 5.50 & $0.0000 \pm 0.0001$ & $0.0161 \pm 0.0002$ & 0.010 & 2.57 & 0.35 & $60.16 \pm 2.13$ & $711.1 \pm 20.8$ \\
\hline 6.00 & $0.0000 \pm 0.0000$ & $0.0115 \pm 0.0002$ & 0.010 & 0.95 & 0.37 & $85.64 \pm 2.75$ & $944.3 \pm 23.6$ \\
\hline 6.50 & $0.0000 \pm 0.0000$ & $0.0067 \pm 0.0001$ & 0.010 & 0.81 & 0.67 & $146.46 \pm 2.53$ & $1402.8 \pm 16.9$ \\
\hline 7.00 & $0.0000 \pm 0.0000$ & $0.0042 \pm 0.0001$ & 0.010 & 0.12 & 10.12 & $232.67 \pm 5.90$ & $1901.2 \pm 29.8$ \\
\hline 7.80 & $0.0000 \pm 0.0000$ & $0.0040 \pm 0.0000$ & 0.010 & 0.23 & 29.10 & $244.98 \pm 1.99$ & $1962.3 \pm 9.7$ \\
\hline 7.90 & $0.0000 \pm 0.0000$ & $0.0040 \pm 0.0001$ & 0.010 & 0.06 & 7.62 & $246.39 \pm 7.02$ & $1969.2 \pm 34.2$ \\
\hline 8.00 & $0.0000 \pm 0.0000$ & $0.0040 \pm 0.0000$ & 0.010 & 0.03 & 10.98 & $249.44 \pm 3.32$ & $1984.0 \pm 16.0$ \\
\hline 8.20 & $0.0000 \pm 0.0000$ & $0.0039 \pm 0.0000$ & 0.010 & 0.16 & 6.47 & $251.55 \pm 6.14$ & 1994.129 .4 \\
\hline 8.40 & $0.0000 \pm 0.0000$ & $0.0039 \pm 0.0000$ & 0.010 & 0.15 & 6.79 & $253.17 \pm 5.28$ & $2001.8 \pm 25.2$ \\
\hline 8.70 & $0.0000 \pm 0.0000$ & $0.0039 \pm 0.0000$ & 0.010 & 0.14 & 5.54 & $252.93 \pm 5.77$ & $2000.7 \pm 27.6$ \\
\hline 9.10 & $0.0000 \pm 0.0000$ & $0.0039 \pm 0.0001$ & 0.010 & 0.16 & 4.06 & $252.24 \pm 7.06$ & $1997.4 \pm 33.8$ \\
\hline 9.60 & $0.0000 \pm 0.0000$ & $0.0040 \pm 0.0000$ & 0.010 & 0.09 & 1.73 & $248.49 \pm 5.29$ & $1979.4 \pm 25.6$ \\
\hline 10.10 & $0.0000 \pm 0.0000$ & $0.0039 \pm 0.0000$ & 0.010 & 0.21 & 7.70 & $253.36 \pm 5.97$ & $2002.8 \pm 28.5$ \\
\hline 10.50 & $0.0000 \pm 0.0000$ & $0.0039 \pm 0.0000$ & 0.010 & 0.02 & 1.22 & $252.33 \pm 5.45$ & $1997.8 \pm 26.1$ \\
\hline 1100 & $0.0000 \pm 0.0000$ & $0.0039 \pm 0.0001$ & 0.010 & 0.16 & 1.91 & $255.67 \pm 6.94$ & $2013.8 \pm 32.9$ \\
\hline 11.50 & $0.0000 \pm 0.0000$ & $0.0038 \pm 0.0000$ & 0.010 & 0.01 & 1.39 & $257.78 \pm 6.66$ & $2023.8 \pm 31.4$ \\
\hline 12.00 & $0.0000 \pm 0.0000$ & $0.0040 \pm 0.0001$ & 0.010 & 0.29 & 0.32 & $246.61 \pm 9.74$ & $1970.2 \pm 47.3$ \\
\hline 14.00 & $0.0000 \pm 0.0000$ & $0.0038 \pm 0.0000$ & 0.010 & 0.15 & 1.81 & $256.30 \pm 5.96$ & $2016.8 \pm 28.2$ \\
\hline 25.00 & $0.0000 \pm 0.0000$ & $0.0040 \pm 0.0000$ & 0.010 & 0.79 & 1.03 & $246.98 \pm 5.64$ & $1972.1 \pm 27.4$ \\
\hline
\end{tabular}


Rochas albitizadas e albititos relacionados a mineralizações de estanho da Província Estanífera de Goiás: caracterização petrológica e gênese.
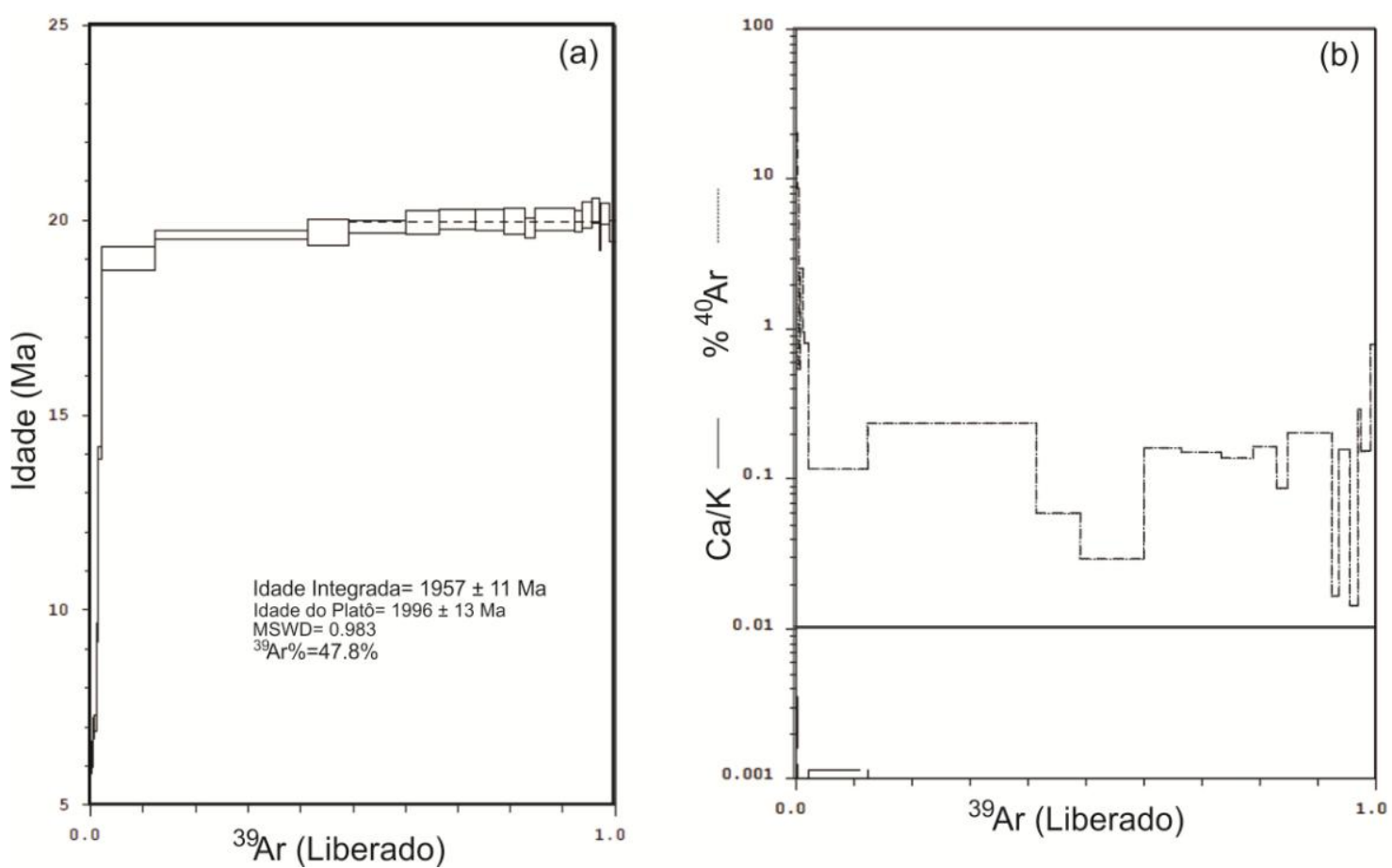

Figura 3.33: Idades-platô ${ }^{40} \mathrm{Ar} /{ }^{39} \mathrm{Ar}$, representando a idade de cristalização da muscovita do garimpo Boa Vista. 


\section{CAPITULO IV -DISCUSSÕES E CONCLUSÕES}

\subsection{DISCUSSÕES}

\subsubsection{PETROGÊNESE DOS ALBITITOS}

Vários modelos petrogenéticos têm sido propostos para explicar a origem dos albititos. O primeiro modelo e o mais comum é atribuído à ação de fluidos hidrotermais em granitos (Cathelineau 1987, Schwartz 1992, Rugless \& Pirajno 1996, Palomba 2001, Castorina et al. 2006, Chaves 2011, Singh et al. 2013). Um segundo modelo e menos comum ocorre por processos ígneos, sendo formado por cristalização de um magma altamente sódico (Schwartz 1992, Blasy et al. 2001, Chaudhri et al. 2003, Pin et al. 2006, Mohammad et al. 2007, Azer et al. 2008, Ghabrial et al. 2013, Wang et al. 2014), normalmente associado a granitos do tipo-A (Costi et al. 2000, Lenharo et al. 2003, Azer et al. 2008), mas também é atribuído a granitos do tipo-S (Schwartz, 1992, Helba et al. 1997).

Albititos atribuídos à ação metassomática normalmente apresentam características petrográficas e químicas bastante diferentes dos albititos atribuídos a processos ígneos. Petrograficamente, no primeiro tipo, a textura original do granito é substituída, sendo formada por novos minerais de alteração. No entanto, ainda se pode observar que, em alguns casos, na textura original da rocha, a albitização é desenvolvida pela substituição de plagioclásio cálcico, K-feldspato e biotita. Dados geoquímicos em albititos hidrotermais sugerem que albitização é acompanhada pela adição de Na, lixiviação de $\mathrm{K}, \mathrm{Fe}, \mathrm{Mg}$ e elementos traços. Alguns elementos podem permanecer imóveis, como o $\mathrm{Ca}$, Th, Nb, Y, Ti, Si, Al, P e ETRP, pois, depois de lixiviados de minerais magmáticos, eles são acomodados em minerais recém-formados (Castorina et al. 2006).

Os albititos de origem magmática apresentam características petrográficas muito peculiares. A principal textura é denominada de "textura Snowball", sendo formada por inclusões de pequenas"ripas" (laths) de albita dispostas paralelamente em relação às fáceis do cristal ou no centro. A formação da textura Snowball pode ser interpretada como resultante decristalização precoce da albita a partir do fundido, sendo seguida pelos outros minerais (Zhu et al. 2001). Isso é confirmado por meio dos dados geoquímicos, sendo que, nos líquidos finais, o $\mathrm{Na}_{2} \mathrm{O}$ se empobrece, indicando que a cristalização da albita ocorreu primeiro e, posteriormente, aconteceu a cristalização dos demais minerais. 
Outra textura típica é o acumulo de albita com fácies bem formadas. Normalmente, essa textura revela um alinhamento de fluxo magmático. Quimicamente, os albititos magmáticos são empobrecidos em $\mathrm{MgO}, \mathrm{MnO}, \mathrm{TiO}_{2}, \mathrm{FeO}, \mathrm{CaO}, \mathrm{K}_{2} \mathrm{O}$ e são enriquecidos em $\mathrm{Na}_{2} \mathrm{O}, \mathrm{Al}_{2} \mathrm{O}_{3}$ e $\mathrm{SiO}_{2}$. As características químicas dos albititos magmáticos são descritas abaixo, com a química das rochas associadas.

Os albititos dos garimpos Pelotas e Boa Vista são compostos por albita, cassiterita, muscovita primária e secundária, quartzo, apatita e K-feldspato. São caracterizados por apresentarem texturas magmáticas típicas, como textura snowball e de fluxo, com alinhamento das "ripas" de albita na matriz. Em algumas amostras de testemunho de sondagem se observa contato retilíneo entre o albitito e monzogranito.

Os dados de isótopos de oxigênio mostraram que a temperatura em que foram formados os albititos e, consequentemente, em que houve a cristalização da cassiterita, foi muito alta, em torno de $653^{\circ} \mathrm{C}$ para os albititos do garimpo Pelotas e 800 a $1016^{\circ} \mathrm{C}$ para os albititos do garimpo Boa Vista. A temperatura de cristalização é um parâmetro muito útil para distinguir os albititos hidrotermais dos albititos magmáticos. A composição isotópica dos fluidos apresentam assinaturas magmáticas, variando de 9,17 a 9,35 para o garimpo Pelotas e 8,68 a 9,72 para o garimpo Boa vista.

Desse modo, em complemento às observações de campo e petrográficas, os dados de litogeoquímica e de isótopos de oxigênio reforçam a interpretação de que os albititos estudados possuem origem magmática.

\subsubsection{CONDIÇÕES DE CRISTALIZAÇÃO DOS ALBITITOS E DAS ROCHAS ASSOCIADAS}

Os garimpos Boa Vista e Pelotas são caracterizados por apresentar mineralização de estanho hospedado em albititos, apresentando caráter peraluminoso a metaluminoso. As rochas associadas são representadas pelos xistos, tonalitos e monzogranitos, sendo esses dois últimos classificados como rochas altamente peraluminosas.

De acordo com os dados geoquímicos, pode-se observar que a evolução dessas rochas ocorreu por processo de cristalização fracionada, podendo ser originadas por fusão parcial de rochas metassedimentares. Essa evolução magmática pode ser melhor observada no gráfico do tipo Harker, tendo o $\mathrm{MgO}$ como índice de diferenciação (Fig. 4.1). 
Granitos peraluminosossão interpretadas como sendo originados, geralmente, de fusão parcial de rochas metassedimentares com alto teor de $\mathrm{Al}_{2} \mathrm{O}_{3}$ em ambiente sincolisional, gerando rochas com alto conteúdo de sílica e contendo muscovita e granada na sua mineralogia (Frost et al. 2001).

As rochas metassedimentares representadas por xistos, geralmente, são atribuídas como rocha-fonte que deu origem a rochas fortemente peraluminosas. Essas rochas foram formadas em ambiente sin-colisional, como indicado pelo diagrama de Pearce et al. (1984).
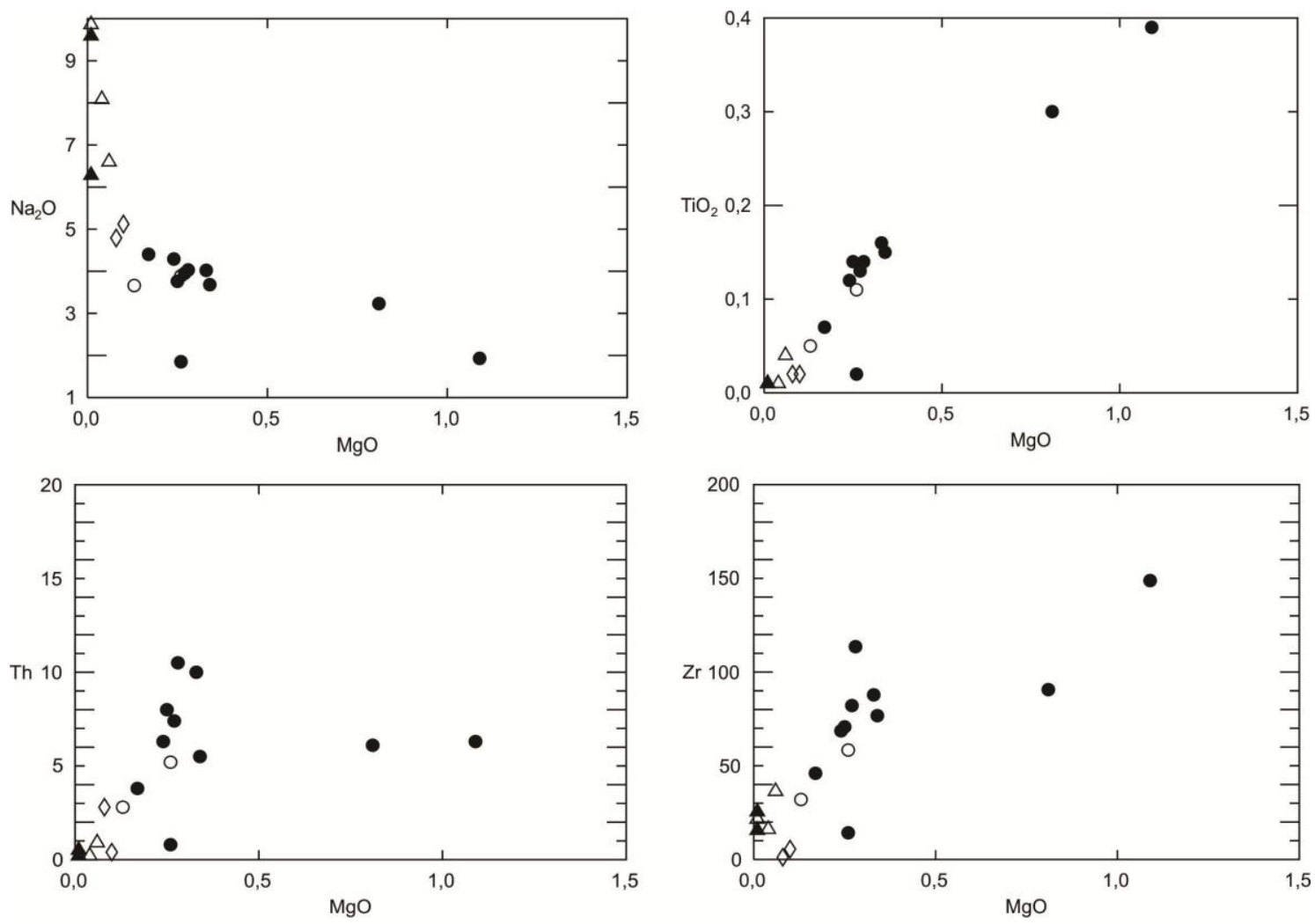

- Muscovita-biotita monzogranito o Biotita-muscovita monzogranito $\checkmark$ Muscovita-biotita tonalito

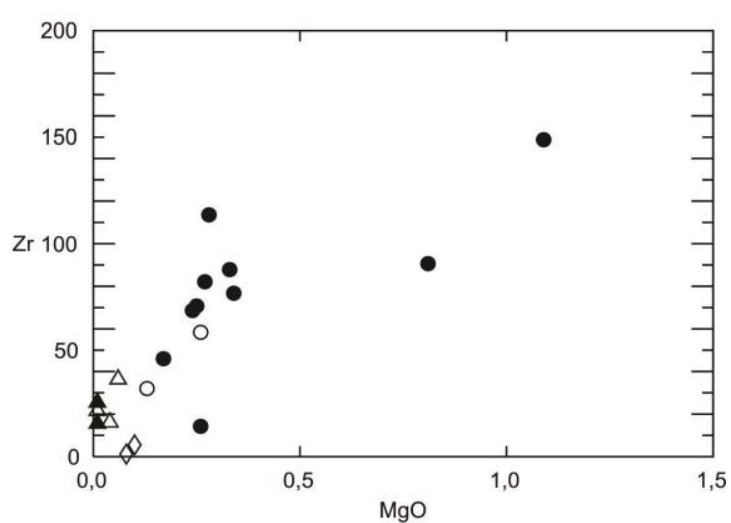

$\triangle$ Albitito Pelotas

$\Delta$ Albitito Boa Vista

Figura 4.1: Relação entre $\mathrm{Na}_{2} \mathrm{O}, \mathrm{TiO}_{2}$, Th, $\mathrm{Zr}$ vs. $\mathrm{MgO}$ revelando a diferenciação magmática das rochas estudadas.

A composição química do plagioclásio varia de 77 a $99 \%$ de albita; a composição química do plagioclásio nos monzogranitoséde albita-oligoclásio $\left(\mathrm{Ab}_{77}\right.$ ${ }_{99} \mathrm{An}_{22-1} \mathrm{Or}_{1}$ ); já nos tonalitos e albititos, a composição química do plagioclásio constituise em, praticamente, albita pura $\left(\mathrm{Ab}_{90-99} \mathrm{An}_{10-0,6} \mathrm{Or}_{0,4}\right)$. Isso indica que essas rochas 
foram geradas de um magma altamente sódico. As composições muito puras de albita também podem ser produto de reequilíbrio subsolidus.

Para gerar magmas altamente evoluídos e ricos em sódio, é necessário um baixo grau de fusão de rochas metassedimentares em altas profundidades, em que os elementos incompatíveis como $\mathrm{Al}, \mathrm{K}, \mathrm{Na}, \mathrm{Ti}, \mathrm{Th}, \mathrm{Zr}, \mathrm{Rb}, \mathrm{Ba}, \mathrm{Cs}, \mathrm{Sn}, \mathrm{Nb}$, Ta e U se enriquecem nas fusões iniciais ou podem ter sido modificados por processos de cristalização fracionada. Segundo Schwartz (1992), as baixas concentrações de elementos compatíveis podem não somente indicar o grau de evolução magmática, mas também refletir a composição especial da fonte de rocha metassedimentar a partir da qual o granito peraluminoso foi derivado.

Os monzogranitos são mais enriquecidos $\mathrm{K}_{2} \mathrm{O}, \mathrm{CaO}, \mathrm{MgO}, \mathrm{TiO}_{2}, \mathrm{Fe}_{2} \mathrm{O}_{3}, \mathrm{Rb}$, Th e $\mathrm{Zr}$ e empobrecidos em $\mathrm{Na}_{2} \mathrm{O}, \mathrm{Al}_{2} \mathrm{O}_{3}, \mathrm{P}_{2} \mathrm{O}_{5}$, $\mathrm{Ba}$ e $\mathrm{Sr}$. Os monzogranitos foram divididos em duas fácies: fácies muscovita-biotita monzogranito e biotita-muscovita monzogranito. A diminuição de $\mathrm{CaO}$ e $\mathrm{Sr}$ e o aumento de $\mathrm{Na}_{2} \mathrm{O}$ indica a evolução dessas rochas para uma composição mais sódica, sendo marcada pela cristalização do plagioclásio com composição variando de albita a oligoclásio. Ocorre diminuição do $\mathrm{K}_{2} \mathrm{O}$ e o aumento do $\mathrm{Ba}$ com relação a composições mais enriquecidas em $\mathrm{SiO}_{2}$. No entanto, o conteúdo de $\mathrm{K}_{2} \mathrm{O}$ é superior ao dos tonalitos, indicando que a cristalização do feldspato potássico foi maior nessa fase. A diminuição do teor de $\mathrm{MgO}, \mathrm{TiO}_{2}$ e $\mathrm{Fe}_{2} \mathrm{O}_{3}$ indica a cristalização da biotita; o $\mathrm{Al}_{2} \mathrm{O}_{3}$ aumenta em direção a composições mais félsicas devido à cristalização da muscovita.

Os tonalitos representam uma fase mais tardia da granitogênese, evidenciada pelo dados geoquímicos: são empobrecidos em $\mathrm{MgO}, \mathrm{MnO}, \mathrm{TiO}_{2}, \mathrm{Fe}_{2} \mathrm{O}_{3}, \mathrm{~K}_{2} \mathrm{O}$ e $\mathrm{CaO}$ e mais enriquecidos em $\mathrm{Al}_{2} \mathrm{O}_{3}, \mathrm{Na}_{2} \mathrm{O}$ e $\mathrm{SiO}_{2}$. Os elementos-traço como Th, $\mathrm{Zr}, \mathrm{Rb}$ apresentam comportamento compatível, se empobrecendo no liquido residual. Por outro lado, o teor de $\mathrm{Ba}$ e $\mathrm{Sr}$ se enriquece. O empobrecimento de $\mathrm{MgO}, \mathrm{TiO}_{2}, \mathrm{Fe}_{2} \mathrm{O}_{3}$ indica a cristalização da biotita.

A cristalização do plagioclásio altamente sódico teve início nessa fase. A diminuição de $\mathrm{CaO}$ e o aumento de $\mathrm{Na}_{2} \mathrm{O}$ em direção às composições mais ácidas refletem uma evolução magmática dessas rochas.

Depois da cristalização das fácies menos evoluídas correspondentes aos tonalitos, o magma residual se enriquece ainda mais em $\mathrm{Na}_{2} \mathrm{O}, \mathrm{Ba}, \mathrm{Th}, \mathrm{Zr}$ e se 
empobrece em $\mathrm{CaO}, \mathrm{MgO}, \mathrm{TiO}_{2}$ e $\mathrm{Fe}_{2} \mathrm{O}_{3}$. O conteúdo de $\mathrm{K}_{2} \mathrm{O}$ e $\mathrm{Rb}$ permanece constante em direção à composição mais rica em $\mathrm{SiO}_{2}$, mostrando dispersão em apenas duas amostras.

Os albititos representam a fase residual do magma, sendo esgotados em $\mathrm{MgO}$, $\mathrm{TiO}_{2}$ e $\mathrm{Fe}_{2} \mathrm{O}_{3}, \mathrm{Ba}$, Th e enriquecidos em $\mathrm{Na}_{2} \mathrm{O}, \mathrm{P}_{2} \mathrm{O}_{5}, \mathrm{Sn}$, Ta e $\mathrm{Nb}$ se comparados aos granitos e tonalitos.

$\mathrm{O}$ conteúdo de $\mathrm{K}_{2} \mathrm{O}$ e $\mathrm{Rb}$ aumenta nos albititos mais ricos em $\mathrm{SiO}_{2}$ devido ao alto grau de evolução dessas rochas, sendo que esses elementos se enriqueceram no líquido final, tornando-se incompatíveis posteriormente. Esse comportamento reflete na cristalização do K-feldspato nos albititos com o conteúdo maior de $\mathrm{SiO}_{2}$.

Por outro lado, elementos como $\mathrm{CaO}, \mathrm{P}_{2} \mathrm{O}_{5}, \mathrm{Na}_{2} \mathrm{O}, \mathrm{Al}_{2} \mathrm{O}_{3}$ e $\mathrm{Sr}$ se tornaram compatíveis, empobrecendo-se nos albititos mais ricos em sílica. $\mathrm{O} \mathrm{CaO}$ e o $\mathrm{P}_{2} \mathrm{O}_{5}$ apresentam comportamentos similares, sendo que o enriquecimento de $\mathrm{CaO}$ nos albititos mais empobrecido em $\mathrm{SiO}_{2}$ é devido à cristalização da apatita.

$\mathrm{O} \mathrm{Na}_{2} \mathrm{O}$ se empobrece no líquido final devido à cristalização precoce da albita emrelação aos outros minerais. Já o $\mathrm{Al}_{2} \mathrm{O}_{3}$ empobrece à medida que a muscovita começa a cristalizar nos albititos com menor teor de $\mathrm{SiO}_{2}$.

O comportamento dos ETRs mostra-se diferente nos quatro tipos de rochas. Nos xistos, os elementos terras raras apresentam-se enriquecidos, sendo levemente fracionados. Nos tonalitos e monzogranitos, observa-se um empobrecimento nos ETRs, principalmente em ETRP. Apresentam-se fortemente fracionados, indicando a presença de granada na fonte (Rollinson 1993).

É importante observar que nos tonalitos apresenta um maior empobrecimento em ETRs e pronunciada anomalia positiva de $\mathrm{Eu}$, indicando acúmulo de plagioclásio. Nos albititos, os ETRs apresentam-se empobrecidos emrelação às rochas associadas e têm comportamento diferente, evidenciando que o líquido residual se enriqueceu em alguns elementos e se empobreceu em outros, levando a um padrão diferenciado das rochas associadas. Essas diferentes concentrações podem ser controladas pela química da fonte ou por um processo cristal-fundido que ocorreu durante a evolução da rocha (Rollinson 1993).

Observa-se, também, um enriquecimento dos ETRM em relação aos ETRL e aos ETRP em algumas amostras. Isso ocorre devido à presença da apatita no líquido residual que deu origem aos albititos (Hanson 1978). 
A evolução dessas rochas também pode ser observada no gráfico ETR x $\mathrm{MgO}$ (Fig.4.2). Os monzogranitos representando os termos menos diferenciados, possuem um alto conteúdo de ETR, seguido pelos tonalitos e albititos.

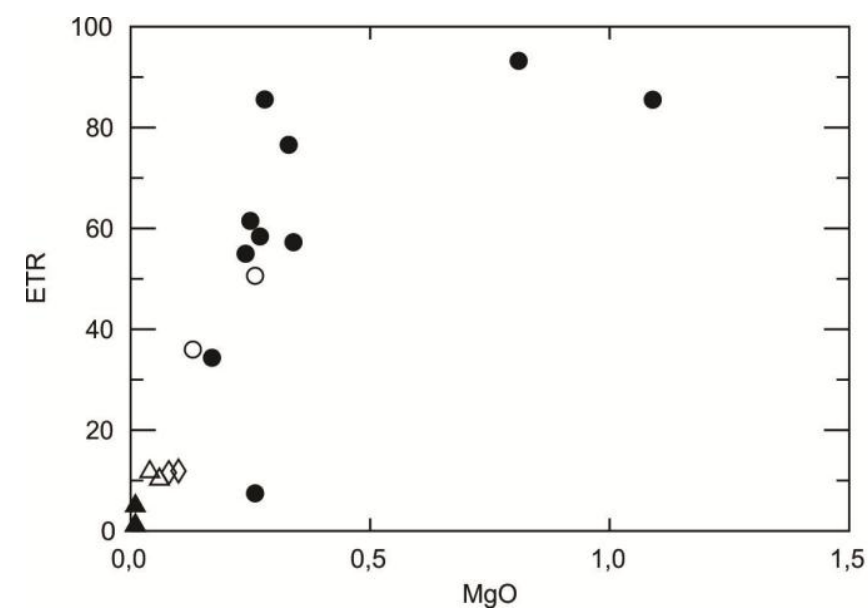

- Muscovita-biotita monzogranito o Biotita-muscovita monzogranito $\diamond$ Biotita-muscovita tonalito $\triangle$ Albitito Pelotas

$\Delta$ Albitito Boa Vista

Figura 4.2: Gráfico ETR vs. MgO mostrando a diminuição do conteúdo de ETR para as fases mais evoluídas.

A ordem de cristalização, portanto, ocorreu da seguinte maneira: primeiro houve a cristalização dos monzogranitos, muscovita-biotitamonzogranito $\rightarrow$ biotita-muscovita monzogranito. Posteriormente, os tonalitos foram formados: muscovita-biotita tonalito $\rightarrow$ biotita-muscovita tonalito. E, por último, com o magma altamente sódico e empobrecido em elementos compatíveis, foram cristalizados os albititos. Essa ordem de cristalização pode ser também corroborada nos gráficos $\mathrm{Na}_{2} \mathrm{O}, \mathrm{TiO}_{2}, \mathrm{Th}, \mathrm{Zr}$ vs. $\mathrm{MgO}$ (Fig.4.1).

\subsubsection{ROCHAS EVOLUIDAS RELACIONADAS À MINERALIZAÇÃO DE ESTANHO}

Devido à sua geoquímica incompatível, Sn é preferencialmente enriquecido em rochas muito fracionadas dentro da crosta terrestre, como rochas graníticas altamente evoluídas (Lehmann 1990). Sn bivalente é um cátion relativamente grande e, devido a esse fator, comporta-se como um elemento incompatível durante a evolução de suítes graníticas. Em geral, a mineralização de $\mathrm{Sn}$ é normalmente relacionado a granitos peraluminosos (Cuney et al. 1992, Raimbault et al. 1995, Huang et al. 2002, Breiter et al. 2007), mas também a granitos do tipo-A (Costi et al. 2000, Lenharo et al. 2003). 
De acordo com Linnen (1998), três diferentes mecanismos têm sido propostos para a cristalização da cassiterita; i) Magmática: cristalização direta da cassiterita a partir de fundidos graníticos (Linnen et al. 1992); ii) Ortomagmático-hidrotermal: o particionamento de estanho para a fase de vapor a partir da massa fundida, seguido pela deposição da cassiterita (Eadington 1983); iii) Redistribuição hidrotermal: a lixiviação de estanho de granito e/ou das rochas encaixantes e recristalização como cassiterita, (Lehmann \& Harmanto1990).

A cassiterita dos garimpos estudados é interpretada neste trabalho como tendo sido formada por cristalização a partir de um magma enriquecido em $\mathrm{Sn}$, portanto, de origem magmática.

A concentração de Sn dependerá de alguns fatores. Primeiramente, o magma tem que ser altamente evoluído com um grau suficientemente elevado de fracionamento. Com isso, a cristalização da cassiterita magmática será inevitável.

Para que a cassiterita possa ocorrer como mineral magmático, o estanho deve ser incompatível em toda a história de cristalização do fundido. O estanho deve ser dividido em favor do líquido silicático, ou a fração de vapor deverá ser suficientemente pequena, de forma que a concentração de estanho no material fundido continuará a aumentar com o fracionamento (Linnen 1998). Essa concentração de Sn também dependerá da profundidade de colocação das intrusões graníticas.

A cassiterita magmática pode cristalizar em sistemas altamente evoluídos, pois o estanho é particionado em favor de fundidos graníticos nas mais profundas intrusões graníticas com baixo teor de cloro (Linnen 1998).

A solubilidade de $\mathrm{SnO}_{2}$ também dependerá da fugacidade de oxigênio. Um aumento na fugacidade de oxigênio reduzirá a solubilidade do estanho (Schwartz et al. 1995).

A presença de voláteis no magma também é um fator muito importante na concentração de Sn. Componentes tais como B e F são, geralmente, concentrados na fase final de magmas evoluídos, e esse enriquecimento é, muitas vezes, considerado como um dos fatores mais importantes na formação de depósitos associado ao minério.

Flúor e boro são envolvidos em um grande número de processos magmáticos e pós-magmáticos em sistemas evoluídos de estanho, incluindo cristalização fracionada, evolução da fase fluida, alteração de transporte do metal e de deposição. 
Os albititos estudados apresentam características do sistema LCT, sendo rochas ricas em Boro e representadas pela cristalização da turmalina. Esse sistema rico em B foi um dos fatores do enriquecimento de $\mathrm{Sn}$ nos líquido finais.

Os albititos dos garimpos Pelotas e Boa Vista apresentam teor de Sn em torno de 3218 e 5143 ppm respectivamente, e o teor de Ta e Nb chega a até 159 ppm (Fig.4.3). As rochas graníticas não apresentam cassiterita em sua mineralogia, e o conteúdo de Sn na biotita e na muscovita não foi observado. Devido a isso, não foi possível saber se a concentração de $\mathrm{Sn}$ teve início apenas no líquido residual que formou os albititos, porém nota-se que o Sn se concentrou principalmente nos últimos estágios de evolução do magma com a cristalização da cassiterita.

De acordo com os dados de química mineral, a cassiterita apresenta teor quase puro de Sn, cerca de 99\%, sendo esteelemento substituído por Ta e $\mathrm{Nb}$ em sua estrutura molecular.
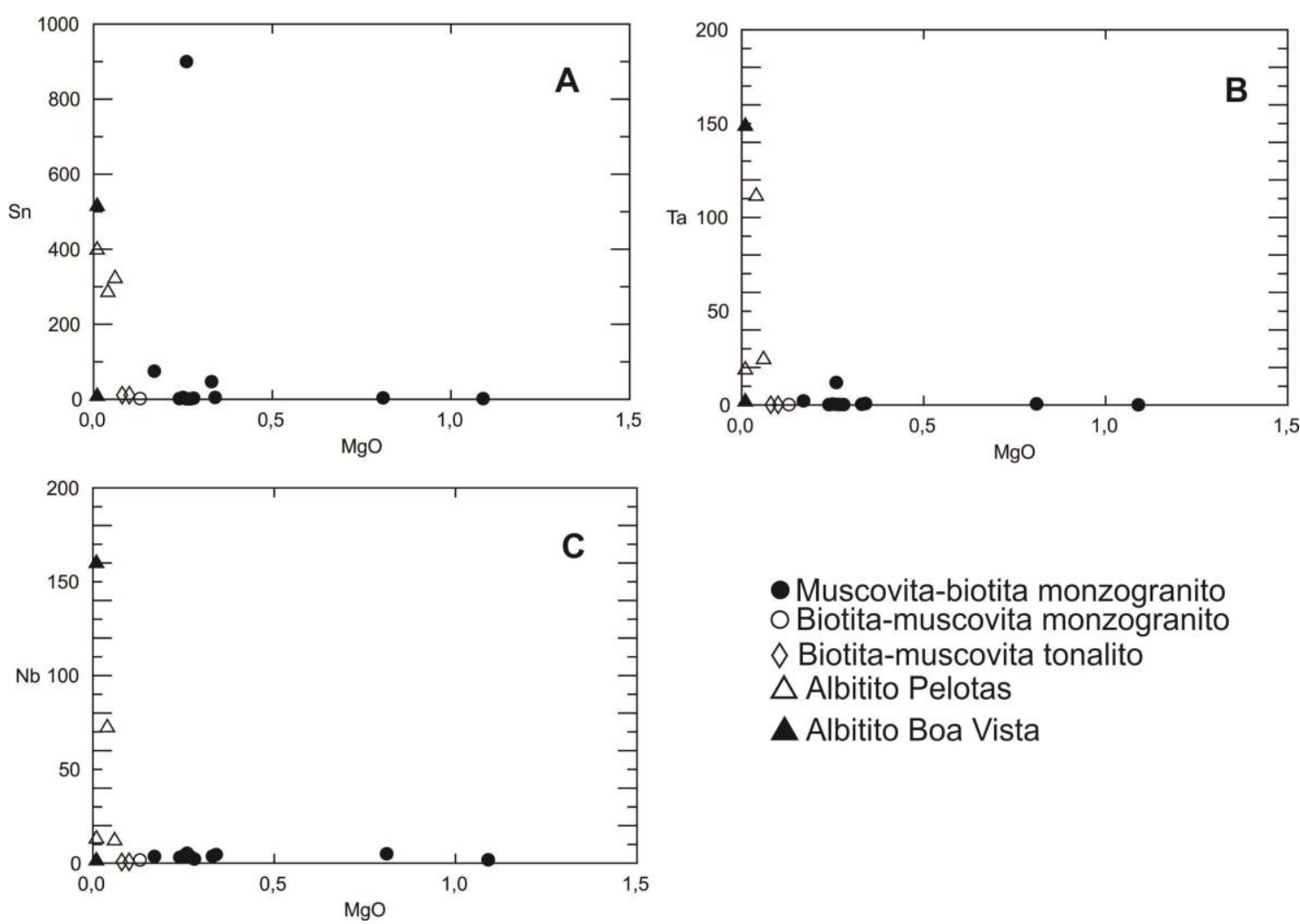

- Muscovita-biotita monzogranito O Biotita-muscovita monzogranito $\diamond$ Biotita-muscovita tonalito $\triangle$ Albitito Pelotas

A Albitito Boa Vista

Figura 4.3: Diagrama $\mathrm{Sn}, \mathrm{Ta}, \mathrm{Nb}$ vs. $\mathrm{MgO}$ mostrando o enriquecimento desses elementos apenas nos albititos. 


\subsubsection{COMPARAÇÃO DOS ALBITITOS E ROCHAS ASSOCIADAS COM O DEPÓSITO DE ESTANHO DA MINA DE PITINGA (PEP) E ROCHAS PERALUMINOSAS DA SUÍTE AURUMINA (PEG)}

Os albititos mineralizados em Sn estudados neste trabalho estão associados a granitos peraluminosos e a xistos. Para comparação, foram escolhidas as rochas graníticas peraluminosas da Suíte Aurumina e rochas metassedimentares da Formação Ticunzal, que ocorrem na Província Estanífera de Goiás (PEG), além da comparação com as fácies albita granito de núcleo e albita granito de borda, com mineralizações primárias de estanho, do Granito Madeira da Mina de Pitinga, localizado na Província Estanífera de Pitinga (PEP), no Amazonas.

A Formação Ticunzal é formada essencialmente por xistos e paragnaisses, freqüentemente grafitosos, constituídos por uma paragênese retrometamórfica, onde ocorrem, em concentrações variáveis: quartzo, clorita, epidoto, carbonato e muscovita fina. As rochas xistosas encontradas na área de estudo apresentam características semelhantes, com presença de grafita, e com presença abundante de clorita, o que é responsável pela coloração esverdeada da rocha. As fácies identificadas, granadaclorita-muscovita-quartzo xisto e grafita-clorita xisto, podem ser correlacionadas às fácies clorita-muscovita-quartzo xisto e grafita xisto da Formação Ticunzal, respectivamente, por apresentarem a mesma mineralogia e os mesmos aspectos texturais.

A Suíte Aurumina é caracterizada por apresentar granitos com predominância de muscovita e, eventualmente, granada ígnea, que são tipicamente sin-tectônicos, apresentando-se intrusivos e deformados concordantemente com a foliação de rochas metassedimentares atribuídas à Formação Ticunzal. Nos tonalitos, a deformação é incipiente e as relações de campo indicam que se trata de uma fase tardia da granitogênese, com características claramente tardi a pós-tectônicas. Outra característica importante e comum, tanto nos granitos quanto nos tonalitos, é a presença de aglomerados ou nódulos de grafita.

As fácies biotita-muscovita e muscovita biotita monzogranito estudadas do garimpo Pelotas podem ser correlacionadas àfácies muscovita granito da Suíte Aurumina (PP2 $\gamma 2 \mathrm{au} 1)$, por possuírem composição mineralógica semelhante. A biotita ocorre como mineral varietal na fácies muscovita granito da Suíte Aurumina, mas pode 
ocorrer até em proporções semelhantes à da muscovita. Por outro lado, a fácies biotitamuscovita e muscovita-biotita tonalito pode ser correlacionada à fácies tonalito da Suíte Aurumina (PP2 $\gamma 2 \mathrm{au} 3)$, principalmente pelo empobrecimento em Th (Fig.4.4) e por ser uma fase tardia.

A Suíte Aurumina é formada por granitos e tonalitos peraluminosos, ricos em $\mathrm{Li}$, $\mathrm{Rb}, \mathrm{P}, \mathrm{Th}, \mathrm{Cs}, \mathrm{Ga}, \mathrm{Sn}$, Ta, alta razão Ta/Nb. Entretanto, apresentam baixos valores de $\mathrm{Ti}, \mathrm{Zr}, \mathrm{Y}$ e ETR e grande fracionamento das terras raras. A química das rochas estudadas nesse trabalho é muito semelhante à das rochas da Suíte Aurumina. Um importante aspecto ocorre na química dos tonalitos, que são mais empobrecidos em Th, $\mathrm{Zr}, \mathrm{Rb}, \mathrm{MgO}, \mathrm{CaO}, \mathrm{Al}_{2} \mathrm{O}_{3}, \mathrm{TiO}_{2}, \mathrm{Fe}_{2} \mathrm{O}_{3}$, e enriquecido em $\mathrm{Na}_{2} \mathrm{O}$ e $\mathrm{SiO}_{2}$ e $\mathrm{Sr}$, o que indica uma fase tardia dessas rochas, correlacionáveis ao tonalitos (PP2 $\gamma 2$ au3) da Suíte Aurumina. A química dos monzogranitos se difere da dos tonalitos. Os monzogranitos são mais enriquecidos em $\mathrm{Th}, \mathrm{Zr}, \mathrm{MgO}, \mathrm{CaO}, \mathrm{Al}_{2} \mathrm{O}_{3}, \mathrm{TiO}_{2}, \mathrm{Fe}_{2} \mathrm{O}_{3}$ e mais empobrecidos em $\mathrm{Na}_{2} \mathrm{O}$ e $\mathrm{SiO}_{2}$ e Sr. Esses dados são consistentes com os dados apresentados na literatura (Botelho et al. 2002, Pereira 2002, Botelho et al. 2006b) sobre as rochas da Suíte Aurumina.

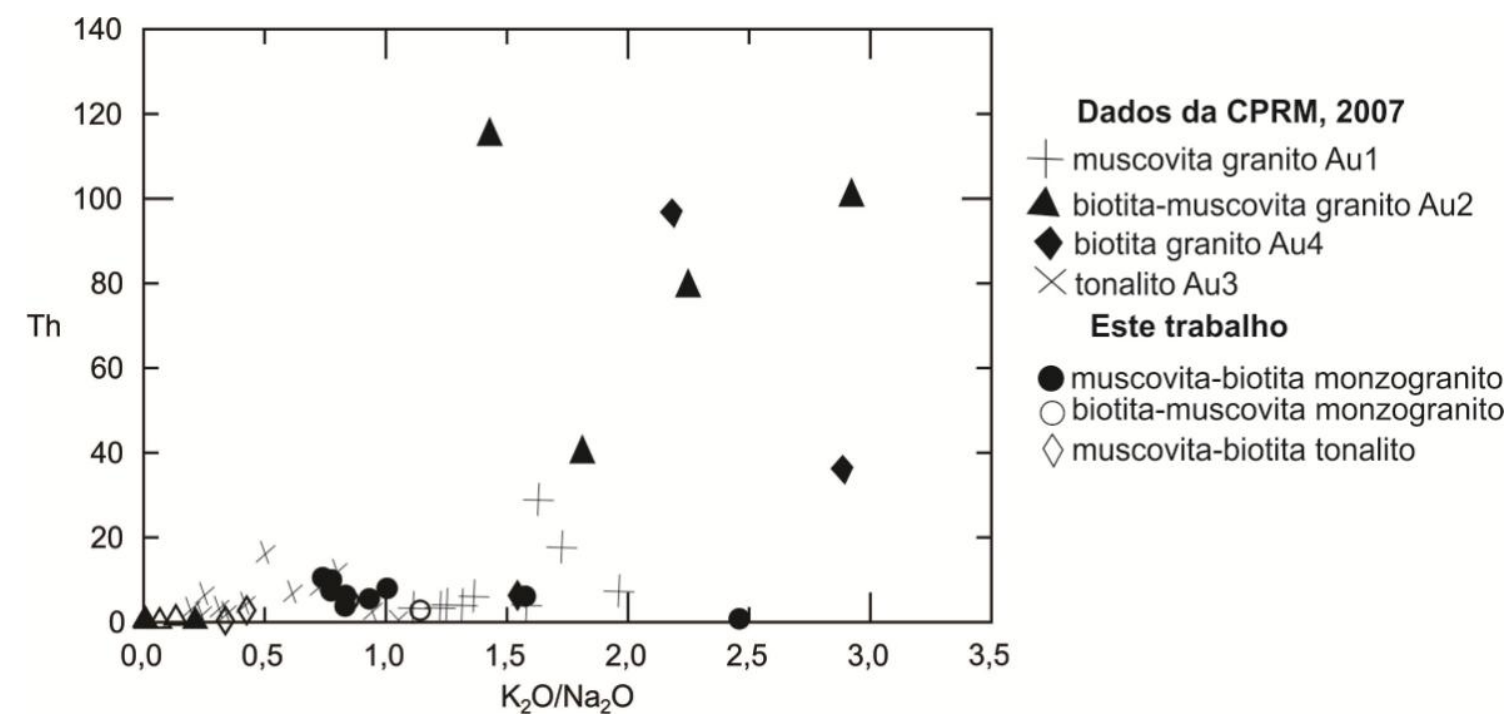

Figura 4.4: Gráfico Th vs. $\mathrm{K}_{2} \mathrm{O} / \mathrm{Na}_{2} \mathrm{O}$ das fácies da Suíte Aurumina em comparação com as rochas estudadas nesse trabalho, com destaque para os altos valores de Th nas fácies Au2 e Au4.

Os albititos apresentam algumas semelhanças petrográficas com o albita granito de núcleo do Granito Madeira (Costi et al. 2000, Lenharo et al. 2003). Essa fácies é caracterizada por conter essencialmente quartzo, albita e feldspato potássico, criolita, zircão, polilitionita, riebeckita, pirocloro, mica, cassiterita e magnetita. O conteúdo de 
K-feldspato é bem maior no albita granito de núcleo chegando até $30 \%$, enquanto que nos albititos o K-feldspato aparece apenas como mineral acessório, fato este que comprova a composição não granítica dos albititos estudados. Um aspecto textural marcante do albita granito de núcleo é a presença freqüente de textura do tipo snowball e texturas ígneas de fluxo. A textura snowball é exibida mais comumente pelos fenocristais ou cristais mais desenvolvidos de quartzo, já nos albititos, a textura snowball pode ser observada mais frequentemente na cassiterita e apatita e mais raramente no quartzo.

Os granitos com mineralizações de Sn e metais raros de Pitinga se diferem em alguns aspectos químicos com os albititos e suas rochas associadas. $\mathrm{O}$ albita granito de núcleo se diferem quanto ao conteúdo de álcalis, sendo mais peralcalino, enquanto que o albita granito de borda é metaluminoso a peraluminoso (Costi et al. 2000). O albita granito de Pitinga é enriquecido em $\mathrm{SiO}_{2}$ e $\mathrm{K}_{2} \mathrm{O}$ e empobrecido em $\mathrm{MgO}, \mathrm{CaO}, \mathrm{MnO}$, $\mathrm{Al}_{2} \mathrm{O}_{3}, \mathrm{TiO}_{2}, \mathrm{Fe}_{2} \mathrm{O}_{3}$ e $\mathrm{P}_{2} \mathrm{O}_{5}$, e tem muito baixo de Ti/Zr (Lenharo et al. 2002). Em termos de elementos traços, todos as fácies do Granito Madeira são enriquecidas em Rb, U, Th, Sn, Nb, Ta, Y, Zr, Hf, Pb e ETR e empobrecido em Sr (Lenharo et al. 2003). Os albititos são mais enriquecidos em $\mathrm{Na}_{2} \mathrm{O}$ e $\mathrm{Al}_{2} \mathrm{O}$ e empobrecidos em $\mathrm{MgO}, \mathrm{CaO}, \mathrm{MnO}$, $\mathrm{TiO}_{2}, \mathrm{Fe}_{2} \mathrm{O}_{3}$ e com valores moderados de $\mathrm{P}_{2} \mathrm{O}_{5}$. Em relação aos elementos-traço são enriquecidos em Sn, Nb, Ta e empobrecidos em Th, Zr, Rb, Sr, Ba e ETR. Os albititos são mais semelhantes ao albita granito de borda em termos de valores de $\mathrm{Na}_{2} \mathrm{O}$ e $\mathrm{Al}_{2} \mathrm{O}$. O albita granito de borda tem sua origem atribuída a processos metassomáticos, enquanto que o albita granito de núcleo apresenta origem magmática, sendo a mesma origem atribuída aos albititos desse estudo, devido as suas características petrográficas e químicas.

Os granitos estaníferos de Pitinga estão associados a granitos geoquimicamente definido como do tipo-A, enquanto que os albititos estudados nesse trabalho estão associados a granitos do tipo-S, sendo esse aspecto que diferencia os granitos portadores de Sn.

Os resultados ${ }^{40} \mathrm{Ar} /{ }^{39} \mathrm{Ar}$ obtidos em muscovita do albitito do garimpo Boa Vista fornecem informações relevantes acerca da formação desses corpos albitícos. O resultado para a idade de cristalização da muscovita $(1996.55 \pm 12.96 \mathrm{Ma})$ permitem propor que os albititos da área foram formado durante o Paleoproterozoico, sendo correlacionados às fases mais tardias do magmatismo peraluminoso da Suíte Aurumina, 
datado em 2,12-2,17 Ga - U-Pb em zircão (Botelho et al. 2006). Assim, a idade de resfriamento da muscovita coincide com a idade da Suíte Aurumina, apresentando um intervalo de mais ou menos, 170 Ma desde a sua cristalização magmática até atingir a temperatura de resfriamento total da muscovita $\left(325\right.$ a $\left.375^{\circ} \mathrm{C}\right)$. Posteriormente à formação dos albititos, ocorreu outro evento que provocou a liberação de $47 \%$ de ${ }^{39} \mathrm{Ar}$

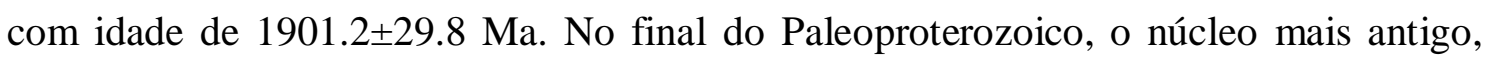
representado aqui pelas rochas da Suíte Aurumina, foi afetado por processo de rifteamento continental, o qual se traduziu sucessivamente pela intrusão, em cerca de 1,8 Ga (Pimentel et al. 1991, Pimentel \& Botelho 2000), dos granitos intraplaca da Suíte Pedra Branca. Essa liberação de ${ }^{39} \mathrm{Ar}$ pode estar relacionada a esse evento. Outra pequena perturbação pode ser observada no intervalo de 631.6ะ34.6 Ma e pode estar relacionada à deformação provocada pelo evento Brasiliano (630 Ma).

\subsection{CONCLUSÕES}

Estudos realizados em xistos, monzogranitos, tonalito, pegmatitos e albititospresentes nos garimpos Pelotas e Boa Vista localizados próximo a cidade de Monte Alegre de Goiás possibilitaram chegar às seguintes conclusões:

O estudo petrográfico possibilitou identificar os seguintes tipos de rocha: xisto, tonalito, monzogranito, pegmatito e albitito. Os xistos foram divididos em duas fácies: granada-biotita-clorita-quartzo xisto e grafita-clorita xisto, interpretados como pertencentes à Formação Ticunzal. Os tonalitos foram subdivididos em duas fácies: biotita-muscovita tonalito e muscovita-biotita tonalito; e os monzogranitos foram divididos em duas fácies: biotita-muscovita monzogranito, muscovita-biotita monzogranito, classificados como pertencentes à Suíte Aurumina. No garimpo Boa Vista, foram descritos apenas albititos, os quais são mais ricos em cassiterita e apatita do que os albititos do garimpo Pelotas.

Os albititos são compostos por albita, cassiterita, muscovita primária e secundária, quartzo, apatita e K-feldspato. São caracterizados por apresentarem texturas magmáticas típicas, como textura snowball e de fluxo, com alinhamento das ripas de albita na matriz. A textura snowball se refere a inclusões poiquiliticas de "ripas"de albita euedral a subedral em fenocristais de cassiterita, apatita e quartzo, ocorre de duas maneiras: a primeira apresenta a textura típica de snowball, com "ripas" de albita muito finas, dispostas paralelamente às bordas do cristal e na segunda, as inclusões de albita 
ocorrem por todo cristal e não apenas em suas bordas. A formação da textura snowball pode ser interpretada como uma cristalização precoce da albita a partir do fundido, sendo seguida pelos outros minerais, ou cristalização simultânea entre a albita e os minerais hospedeiros. As características magmáticas dos albititos podem ser confirmadas por meio dos dados geoquímicos.

Os xistos apresentam teor de $\mathrm{SiO}_{2}$ entre 49,83 e 50,29\%, os granitos apresentam valores de $\mathrm{SiO}_{2}$ entre 70,94 a 75,89\% e os tonalitos apresentam valores entre 72,49 a $74,89 \%$. As rochas graníticas são classificadas como rochas peraluminosas (ISA=1,1 a 1,8), já os albititos apresentam teores de $\mathrm{SiO}_{2}$ entre 70,48 e $75,86 \%$ e são classificados como rochas metaluminosas a peraluminosas (ISA=0,8 a 1,3). Os albititos apresentam um enriquecimento em teores de $\mathrm{Na}_{2} \mathrm{O}, \mathrm{Al}_{2} \mathrm{O}_{3}, \mathrm{P}_{2} \mathrm{O}_{5}, \mathrm{Sn}$, Ta, $\mathrm{Nb}$ e $\mathrm{Rb}$ e moderado em $\mathrm{CaO}$ e empobrecimento em $\mathrm{K}_{2} \mathrm{O}, \mathrm{TiO}_{2}, \mathrm{Fe}_{2} \mathrm{O}_{3}, \mathrm{MgO}, \mathrm{Ba}, \mathrm{Th}, \mathrm{Sr}$ e $\mathrm{Zr}$. As rochas associadas aos albititos representadas por xistos, tonalitos e monzogranitos são enriquecidas $\mathrm{Al}_{2} \mathrm{O}_{3}, \mathrm{TiO}_{2}, \mathrm{Fe}_{2} \mathrm{O}_{3}, \mathrm{MgO}, \mathrm{CaO}, \mathrm{K}_{2} \mathrm{O}, \mathrm{Ba}, \mathrm{Th}, \mathrm{Zr}, \mathrm{Rb}$, e possuem baixos teores de $\mathrm{Na}_{2} \mathrm{O}, \mathrm{P}_{2} \mathrm{O}_{5}, \mathrm{Sr}, \mathrm{Sn}, \mathrm{Nb}$ e Ta. Características de campo, petrograficas e geoquímicas confirmam que os monzogranitos e tonalitos foram gerados em ambiente sin-colisionais.

Dados de química mineral confirmam que tanto os albititos como os tonalitos e monzogranitos apresentam composições altamente sódicas. Nas rochas mais evoluídas, albititos e tonalitos, o plagioclásio apresenta composição de albita $\left(\mathrm{Ab}_{90-99} \mathrm{An}_{10-0,6} \mathrm{Or}_{0,4}\right)$. Nos monzogranitoso plagioclásio apresenta composição variando de albita a oligoclásio $\left(\mathrm{Ab}_{77-99} \mathrm{An}_{22-1} \mathrm{Or}_{1}\right)$.

A cassiterita ocorre nos albititos. Foi interpretada como tendo origem magmática. Apresentateores elevados de $\mathrm{Nb}_{2} \mathrm{O}_{5}, \mathrm{Ta}_{2} \mathrm{O}_{5}$ e FeO, com composições muito puras de $\mathrm{SnO}_{2}$. A concentração de $\mathrm{Ta}_{2} \mathrm{O}_{5}$ nas cassiteritas é muito alta em comparação com a concentração de $\mathrm{Nb}_{2} \mathrm{O}_{5}$.

A biotita apresenta composição de siderofilita, com razão $\mathrm{Fe} /(\mathrm{Fe}+\mathrm{Mg})$ entre 0,58 a 0,71 a.f.u., com conteúdo de $\mathrm{Al}^{\mathrm{IV}}$ entre 2,1 a 3,3 a.f.u.. Possui composição de biotita de granitos peraluminosos. Algumas análises de muscovita magmática da fácies biotitamuscovita tonalito resultaram em baixo teor de $\mathrm{Ti}(0,0$ a.f.u. $)$ e outras, teores altos de $\mathrm{Ti}$ (0,114 a.f.u.), além de também altos teores em $\mathrm{Al}, \mathrm{Mg}, \mathrm{Na}$ e conteúdo baixo de $\mathrm{Fe}$ e $\mathrm{Si}$ com relação à razão $\mathrm{Fe} /(\mathrm{Fe}+\mathrm{Mg})$. Por outro lado, a muscovita secundária apresenta 
baixos teores de $\mathrm{Ti}(0,0-0,003$ a.f.u.). Todas as análises de muscovita dos albititos resultaram em baixo teor de $\mathrm{Ti}$ (0,0-0,002 a.f.u.), bem menos do que os teores de muscovita secundária da fácies biotita-muscovita tonalito. As muscovitas dos albititos caíram no mesmo campo das muscovitas secundárias da fácies biotita-muscovita tonalito, com exceção do $\mathrm{Na}$ e $\mathrm{Fe}$, sendo as muscovitas dos albititos mais enriquecidas em $\mathrm{Na}$ e mais empobrecida em Fe.

As apatitas estudadas apresentam composição de fluorapatita, sendo esta composição típica de apatitas ígneas. O conteúdo de flúor nas apatitas do garimpo Pelotas é maior, enquanto que a apatita do garimpo Boa Vista é um pouco mais enriquecida em $\mathrm{Cl}$.

Os dados de geoquímica e química mineral de cassiterita apresentados neste trabalho mostram que os tonalitos, monzogranitos e albititos atribuídas à Suíte Aurumina apresentam características do sistema LCT, porém, foi observado que os albititos, que são mineralizados em estanho, apresentam alto teor de $\mathrm{Cs}, \mathrm{Rb}, \mathrm{Be}, \mathrm{Ga}, \mathrm{Sn}$, $\mathrm{Nb}<\mathrm{Ta}$, $\mathrm{P}$, e baixos teores de Ti, Zr, Y e ETR. Dados de química mineral da cassiterita, que ocorre essencialmente nos albititos dos garimpos Pelotas e Boa Vista, revelam que o conteúdo de Ta predomina sobre o conteúdo de Nb, característica do sistema LCT.

Dados de isótopos de oxigênio em albitito mostraram altos valores de $\delta^{18} \mathrm{O}$ na albita $\left(\delta^{18} \mathrm{O}_{\mathrm{VSMOW}}=6,7\right.$ a $9,3 \%$ o $)$ e cassiterita $\left(\delta^{18} \mathrm{O}_{\mathrm{VSMOW}}=5,3\right.$ a $6,6 \%$ ) e isso evidência um magma muito evoluído. A composição isotópica dos fluidos do garimpo Pelotas varia de 9,17 a 9,35\% e do garimpo Boa Vista varia de 8,68 a 9,72\%. Essas composições são condizentes com fluidos de origem magmática. As temperaturas obtidas foram de 653 para o albitito do garimpo Pelotas e de 800 e $1016^{\circ} \mathrm{C}$ para os albititos do garimpo Boa Vista. Temperaturas muito elevadas são comumente reportadas a corpos ígneos plutônicos que cristalizaram em várias etapas. Assim, o comportamento de ${ }^{18} \mathrm{O}$ durante a cristalização pode ser visto apenas como um produto final, portanto, os isótopos de oxigênio permaneceram como um sistema fechado durante a extrema cristalização fracionada do magma.

Datação ${ }^{40} \mathrm{Ar} /{ }^{39} \mathrm{Ar}$ em muscovita dos albititos do garimpo Boa Vista resultou em idade-platô de $1996 \pm 13$ Ma, concordando com a idade integrada de $1957 \pm 11$ Ma. Essa idade é considerada a idade de resfriamento da muscovita e permite sugerir que os albititos da área foram formados durante o Paleoproterozóico, sendo 
Correlacionados às fases finais de cristalização da Suíte Aurumina $(2,12-2,17 \mathrm{Ga}-\mathrm{U}$ $\mathrm{Pb}$ em zircão) (Botelho et al. 2006).

Os dados apresentados neste trabalho permitem concluir que os albititos estudados são de origem magmática, tendo sido formados por cristalização de um magma altamente sódico, sendo que esse magma altamente evoluído passou por vários processos de cristalização fracionada. Os tonalitos e monzogranitos mostraram-se também relativamente ricos em $\mathrm{Na}_{2} \mathrm{O}$, o que é evidenciado pela química do plagioclásio. Essa composição pode estarligada ao baixo grau de fusão de rochas metassedimentares que deram origem a essas rochas.

A ordem de cristalização sugerida para as rochas estudadas é monzogranitotonalito-albitito. Primeiro houve a cristalização dos monzogranitos: muscovita-biotita monzogranito $\rightarrow$ biotita-muscovita monzogranito. Posteriormente, os tonalitos foram formados: muscovita-biotita tonalito $\rightarrow$ biotita-muscovita tonalito. E, por último, com o magma altamente sódico e empobrecido em elementos compatíveis, foi cristalizado os albititos.

Os resultados obtidos no presente trabalho demonstram que, além de conter mineralização de estanho hidrotermal, hospedada em greisens e associada ao magmatismo granítico intraplaca de aproximadamente 1,7 Ga, a Província Estanífera de Goiás possui concentrações econômicas de estanho magmáticas, hospedadas em albitito ígneo e formadas por cristalização fracionada de granitos peraluminosos da Suíte Aurumina, de aproximadamente 2,0 Ga. Esses resultados, portanto, ampliam as possibilidades de fonte de estanho na Província Estanífera de Goiás e têm implicações para o potencial econômico da Província.

Estudos experimentais ou petrológicos adicionais devem ser realizados para avaliar a existência de relação genética entre o magmatismo intraplaca e o magmatismo sin-colisional e, por conseguinte, entre a concentração hidrotermal e a magmática de estanho na Província Estanífera de Goiás. Sugerem-se, ainda, estudos para verificar o papel dos xistos da Formação Ticunzal na gênese dos granitos peraluminosos e na fonte de estanho na Província Estanífera de Goiás. 


\section{REFERÊNCIAS}

Abdel-Rahman A. M. 1994. Nature of biotites from alkaline, calci-alkaline and peraluminous magmas. J. Petrol, 35:525-541.

Abdalla, H. M., Matsueda, H., Obeid, M. A. 2008. Chemitry of cassiterite in rare metal granitoids and the associated rocks in the Eastern Desert, Egypt. Journal of Mineralogical and Petrological Sciences, 103: 318-326.

Alvarenga, C. J. S., Botelho, N.F., Dardenne, M.A., Campos, J.E.G., Martins, F.A.L., Meneses, P.R., Moura, M.A. 2000. Magmatic and stratigraphic evolution of a Paleo/Meso Proterozoic syn-rift to post-rift Basin: example of the Araí Basin, Brazil. In: 31st International Geology Congress, Rio de Janeiro, Brazil, Abstract. Rio de Janeiro, Geol. Surv. Brazil [CD-ROM].

Alvarenga, C. J. S., Botelho, N. F., Dardenne, M. A., Lima, O. N. B., Machado, M. A. 2007. Monte Alegre de Goiás - SD.23-V-C-III, escala 1:100.000: nota explicativa integrada com Nova Roma E Cavalcante. Goiás: UnB/CPRM. 67p; 01 mapa geológico (Série Programa de Geologia do Brasil - PGB) versão em CD-Rom.

Azer, M. K., Stern, R. J. Kimura, J. I. 2008. Origin of a late Neoproterozoic $(605 \pm 13$ Ma) intrusive carbonate-albitite complex in Southern Sinai, Egypt. Int J Earth Sci (Geol Rundsch), 99: 245-267.

Barbosa, O. 1969. Geologia e inventário dos recursos minerais do Projeto Brasília: relatório Prospec/DNPM. Rio de Janeiro. 225p.

Boulvais, P., Ruffet, G., Cornichet, J., Mermet, M. 2007. Cretaceous albitization and dequartzification of Hercynian peraluminous granite in the Salvezines Massif (French Pyrenees). Lithos, 93: 89-106.

Borges, R. M. K. 2002. Greisens e epissienitos potássicos associados ao Granito Água Boa, Pitinga (AM): um estudo dos processos hidrotermais geradores de mineralizações estaníferas. Tese de Doutorado, Centro de Geociências, Universidade Federal do Pará, Belém, 383p.

Botelho, N. F., 1992. Les ensembles granitiques subalcalins a peralumineux mineralise's en Sn et In de la Sous-Province Paranã , Etat de Goias, Brésil. Dr thesis, Univ. Paris VI, France.

Botelho, N. F. 2002. Granitogênese peraluminosa Transamazônica no embasamento da Faixa Brasília e seu significado tectônico. In: Congresso brasileiro de Geologia. Anais, 41: 436.

Botelho, N. F., Alvarenga, C.J.S., Menezes, P.R., D’el Rey Silva, L.J.H., 1999. Suíte Aurumina: uma suíte de granitos paleoproterozóicos, peraluminosos e sin-tectônicos na Faixa Brasília. Anais. Seventh Simp. Geol. Centro-Oeste, Brasília, p. 17 (in Portuguese). 
Botelho, N. F., Fuck, R. A., Dantas, E. L., Laux, J. H., Junges, S. L. 2006. The Paleoproterozoic peraluminous Aurumina granite suite, Goiás and Tocantins, Brazil: Geological, whole rock geochemistry and $\mathrm{U}-\mathrm{Pb}$ and $\mathrm{Sm}-\mathrm{Nd}$ isotopic constraints. In The Paleoproterozoic Record of the São Francisco Craton (F.F. Alkmin\& M. Noce, eds.). IGCP 509 annual meeting, Brazil. Field Guide \& Abstracts, 91.

Botelho, N. F., Moura, M. A. 1998, Granite-ore deposits relationship in central Brazil. J. South Am. Earth Sci, 11(5): 427-438.

Botelho, N. F., Portela, J. F. 2005. Caracterização petrográfica e geoquímica das rochas metassedimentares da Formação Ticunzal, no contexto da Suíte Granítica Aurumina, Goiás. In: Simpósio de Geologia do Centro Oeste, 9., 2005, Goiânia. Atas, Goiânia: SGB-Núcleo Centro-Oeste e Brasília, p. 36-38.

Bottinga, Y. \& Javoy, M. 1973. Comments on oxygen isotope geothermometry. Earth and Planetary Science Letters, 20: 250-265.

Buda, G., Molnár, E. P., Koller, F. 2012. Mafic enclaves in peraluminous Variscan granitoid in the Battonya Unit from Southeast Hungary. Geologia Croatica, 65(2): 243253.

Blasy, M., A. F. El-Baroudy, M. Kharbish, Sh, 2001. Geochemical characteristics of Wadi Tarr albitite, southeastern Sinai, Egypt. Egypt. J. Geol., 45(2): 767-780.

Breiter, K., Škoda, R., Uher, P., 2007. Nb-Ta-Ti-W-Sn-oxide minerals as indicators of a peraluminous P- and F-rich granitic system evolution: Podlesí, Czech Republic. Mineralogy and Petrology, 91: 225-248.

Campbell, A. R. \& Larson, P. B. 1998. Introduction to Stable Isotope applications in hydrothermal systems. In: Richards, J. P. \& Larson, P. B. (eds) Reviews in Economic Geology, 10, Techiniques in hydrothermal ore deposits geology. Michigan: SEG, 173193.

Cathelineau, M. 1987. U-Th-REE mobility during albitization and quartz dissolution in granitoids: evidence from South-East French Massif Central. Bull. de Minér, 110: 249259.

Castorina, F., Masi, U., Padalino, G., Palomba, M. 2006. Constraints from geochemistry and $\mathrm{Sr}-\mathrm{Nd}$ isotopes for the origin of albitite deposits from Central Sardinia (Italy). Miner Deposita, 41: 323-338.

Černý P. 1991. Fertile granites of Precambrian rare-element pegmatite fields: is geochemistry controlled by tectonics setting on source lithologies? Precambrian Research, 51: 429-468.

Černý, P., Ercit, T. S. 2005. The classification of granitic pegmatites revisited. Canad Mineral, 43: 2005-2026. 
Corsini, M., Figueiredo, L. L., Caby, R., Feraud, G. , Ruffet, G. , Vauchez, A. 1997. Thermal history of the Pan-African/Brasiliano Borborema Province of northeast Brazil deduced from $4^{\circ} \mathrm{Ar} / 39 \mathrm{Ar}$ analysis. Tectonophysics, 285: 103-117.

Costi, H. T., Horbe, A. M. C., Borges, R. M. K., Dall'agnol, R., Rossi, O. R. R., Sighnolfi, G. P. 2000. Mineral chemistry of cassiterites from Pitinga Province, Amazonian Craton, Brazil. Rev. Bras.Geoc., 30: 775-782.

Chappell, B. W. \& White, A. J. R. 1974. Two contrasting granite types. Pac. Geology, 8:173-174.

Chaves, A. M. D. V. 2005. Mineralogia e geoquímica supergênica do Urânio Província Uranífera de Lagoa Real, Caetité - Bahia. Dissertação de mestrado. Centro de Desenvolvimento da Tecnologia Nuclear. Belo Horizonte, 101p.

Chaves, A. O. 2011. Petrogenesis of the Uraniferous Albitites, Bahia, Brazil. Revista de Geologia, 24: 64 - 76.

Chaves, A. O. 2013. New geological modelo $f$ the Lagoa Real uraniferous albitites from Bahia (Brazil). Central european Journal of Geosciences, 5(3): 354-373.

Chaudhri, N., Kaur, P., Okrusch, M., and Shimrascczyk, A. 2003. Characterization of the Dabla granitoids, Noeth Khetri Copper Belt, Rajasthan, India: evidence of bimodal anorogenic felsic magmatism. Gondwana Research, 6(4): 879-895.

Clayton, R., Mayeda, T.K. 1963. The use of bromine pentafluoride in the extraction of oxygen from oxides and silicates for isotopic analysis. Geochim. Cosmochim. Acta 27: 43-52.

Cuney, M., Marignac, C., Weisbrod, A., 1992. The Beauvoir topaz-lepidolite albite granite (Massif Central France): the disseminated magmatic $\mathrm{Sn}-\mathrm{Li}-\mathrm{Ta}-\mathrm{Nb}-\mathrm{Be}$ mineralization. Economic Geology, 87: 1766-1794.

Dall'agnol, R. Titanita-biotita granitos do Baixo Rio Uaupés, Província Rio Negro, Amazonas. Parte II: Geoquímica e Petrogênese. 1992. Revista Brasileirade Geociências, 22(1): 15-28.

Dardenne, M. A. 1998. Geologia do Parque Nacional da Chapada dos Veadeiros, GO: plano de Manejo do Parque Nacional da Chapada dos Veadeiros - PNCV. Brasília: UnB-IBAMA, 38p.

Dardenne, M. A. 2000. The Brasília fold belt. In: International Geological Congress, Rio de Janeiro. Tectonic Evolution of South America. Rio de Janeiro: SGB, 31: 231263.

Dardenne, M. A. \& Schobbenhaus, C. (Eds.) 2001. Metalogênese do Brasil. UnB. Brasília. 422 pp. 
Dalrymple G. B., Alexander Jr. E. C., Lanphere M. A., Kraker G. P. 1981. Irradiation of samples for ${ }^{40} \mathrm{Ar} /{ }^{39} \mathrm{Ar}$ dating using the Geological Survey TRIGA Reactor, U.S. Geological Survey, Professional Paper 1176, 55 p.

Deer, W. A., Howie, R. A., Zussman, J. 1963. Rock forming minerals, Sheet Silicates. Longman Green and Co., 270p.

Deer W. A., Howie R. A., Zussman J. 1982. Rocks forming minerals.Vol 1A Orthosilicates, London, Longman Ed,668p.

Dyer, R. C. 1970. Grupo Araí. Um Grupo de metamorfitos do Centro-Leste de Goiás, Revista da Escola de Minas, Ouro Preto, 28p.

Dymek, R. F. Titanium, aluminum and interlayer cation substitutions in biotite from high-grade gneisses, West Greenland. American Mineralogist, 68: 880-899, 1983.

Eadington, P. J. 1983. A fluid inclusion investigation of ore formation in a tinmineralized granite, New England, New South Wales. Econ Geo, 78: 1204-1221.

Eiler, J. M. 2001. Oxygen Isotope Variations of Basaltic Lavas and Upper Mantle Rocks. Mineralogy. 319-364.

Feio, G. R. L. 2007. Petrografia e Geoquímica dos Greisens Associados ao TopázioGranito do Pluton Água Boa, Província Estanífera de Pitinga (Am). Dissertação de Mestrado. Universidade Federal do Pará. Bélem, Pa, 136p.

Fernandes, P. E. C. A. 1982. Formação Ticunzal. In: Ministério das Minas e Energia. Projeto Radam Brasil, Folha SD-23. Brasília, p. 61-63.

Fõrster, H. J. Tischendorf, G., Trumbull, R.B. 1997. An evaluation of the Rb vs. (Y + $\mathrm{Nb}$ ) discrimination diagram to infer tectonic setting of silicic igneous rocks. Lithos, 40: 261-293.

Frost, B. R., Barnes, C. G., Collins,W. J., Arculus, R. J., Ellis, D. J. \& Frost, C. D. 2001. A geochemical classification for granitic rocks. Journal of Petrology,42: 2033-2048.

Fuck, R. A. 1988. Coberturas metassedimentares do Proterozóico Médio: os grupos Araí e Paranoá na região de Niquelândia - Colinas, Goiás. Revista Brasileira de Geociências, 18:54-62.

Fuck R. A., Pimentel M. M., D’el-Rey Silva L. J. H. 1994. Compartimentação Tectônica na Porção Oriental da Província Tocantins. In: SBG, Cong. Bras. Geol., 38, Camboriú,Anais. Resumos Expandidos, 1:215-216. 
Fuck, R. A. Pimentel, M. M. Soares J. E., Dantas, E. L. 2005. Compartimentação da Faixa Brasília. In: Simpósio de Geologia do Centro-Oeste, 9, 2005, Goiânia. Anais. Goiânia: SBG :26-27.

Ghabrial, D. S., Ali-Bik, M. W., Wahab, W. A. 2013. Albitites of Tarr Complex, Kid area, southeastern Sinai: petrology, geochemistry and Petrogenesis. Journal of Applied Sciences Research, 9(7): 4443-4462.

Guanhu, P., 1997. Discussion on the Genesis of albititos and breccias belt in the bast of Qinling, shaanxi, China. Geology of Shaanxi, 15(1): 46-50.

Haapala, I. 1997. Magmatic and Postmagmatic Processes in Tin-mineralized Granites: Topaz-bearing Leucogranite in the Eurajoki Rapakivi Granite Stock, Finland. Journal of Petrology, 38(12): 1645-1659.

Hanson, G. N. 1978. The application of trace elements to the petrogenesis of igneous rocks of granitic composition. Earth Planet Sci Lett 38:26-43.

Harris, N. B. W.; Pearce, J. A.; Tindle, A. G. Geochemical characteristics of collisionzone magmatism. In: COWARD, M.P.; RIES, A.C., ed. Collision Tectonics. London: The Geological Society, 1986. p. 67-81. (Geological Society Special Publication, n. 19).

Harris, C.; Smith, S. H.; Le Roex, A. P. 2000. Oxygen isotope composition of phenocrysts from Tristan da Cunha and Gough Island lavas: variation with fractional crystallization and evidence for assimilation. Contrib Mineral Petrol. 138: 164-175.

Harrison, T. N. 1990. Chemical variation in micas from the Cairngorm pluton, Scotland. Mineralogical Magazine, 54: 376.

Helba R. B, Trumbull G, Morteani SO, Khalil A, Arslan A. I. 1997. Geochemical and petrographic studies of Ta mineralization in the Nuweibi albite granite complex, Eastern Desert, Egypt. Miner Depos, 32:164-179.

Hogarth, D. D. 1989. Pyrochlore, apatite and amphibole: Distinctive minerals in carbonatite. In: Bell, K. (ed) Carbonatites: Genesis and Evolution. Unwin Hyman, London, 105-148.

Huang, X.L., Wang, R. C., Chen, X. M., Hu, H., Liu, C. S., 2002. Vertical variations in the mineralogy of the Yichun topaz-lepidolite granite, Jiangxi Province, southern China. Canadian Mineralogist, 40(4): 1047-1068.

JiHua, T., WuXian, L., YuanFeng, C., Tao, C. 2014. Mineralogical feature and geological significance of muscovites from the Longyuanba Indosinian and Yanshannian two-micagranites in the eastern Nanling Range. Science China: Earth Sciences.

Johnson, C. A., and Harlow, G. E. 1999. Guatemala jadeitites and albitites were formed by deuterium-rich serpentinizing fl uids deep within a subduction zone: Geology, 27: $629-632$. 
Jones, A. E. W., Migdisov, A. A., Samson, I. M. 2012. Hydrothermal Mobilisation of the Rare Earth Elements - a Tale of "Ceria" and "Yttria. Elements, 8: 355-360.

Kalamarides, R. I. 1986. High-Temperature Oxygen Isotope Fractionation Among The Phases Of The Kiglapait Intrusion, Labrador, Canada. Chemical Geology (Isotope Geoscience Section), 58: 303-310.

Kaur, P., Chaudhri, N., Hofmann, A. W., Raczek, I. Okrusch, M., Skora, S., Baumgartner, L. P. 2008. Two-Stage, Extreme Albitization of A-type Granites from Rajasthan, NW India. Journal of Petrology, 53(5): 919-948.

Koh, J. S., \& Yun, S. H. 1999. The compositions of biotite and muscovite in the Yuksipryong two-mica granite and its petrological meaning. Geosciences Journal, 3(2): 77- 86.

Lenharo, S. L. R., Pollard, P. J., Born, H. 2002. Petrology and textural evolution of granites associated with tin and rare-metals mineralization at the Pitinga mine, Amazonas, Brazil. Lithos, 66: 37- 61.

Leroy, J. L. \& Turpin, L. 1988. REE, Th and U behavior during hydrothermal and supergene processes in a granitic environment. Chem. Geol., 68: 238-251.

Lehmann, B. 1990. Metallogeny of tin. Lecture notes in Earth Sciences, 32. Berlin: Springer-Verlag, 211p.

Lehmann, B. \& Harmanto, A. 1990. Large-scale tin depletion in the Tanjungpandan tin granite, Belitung Island, Indonesia. Economic Geology, 85: 99-111.

Linnen, R. L. 1998. Depth of emplacement, fluid provenance and metallogeny in granitic terranes: a comparison of western Thailand with other tin belts. Mineralium Deposita, 33: 461-476.

Linnen R. L, Williams-Jones, A. E, Martin, R. F. 1992. Evidence of magmatic cassiterite mineralization at the Nong Sua aplite-pegmatite complex, Thailand. Can Mineral, 30: 739-761.

Lobato, L. M., Forman, J. M. A., Fuzikawa, K., Fyfe, W. S., Kerrich, R. 1983. Uranium in overthrust Archean Basement, Bahia, Brazil, Canadian Mineralogist, Ontario, 21: 647-654.

Marini, O. J. 1978. Nova unidade litostratigráfica do Pré-Cambriano do estado de Goiás. In: Congresso Brasileiro de Geologia, 30., 1978, Recife. Boletim Especial... Recife: SBG, 1: 126-127.

Marini, O. J., \&Botelho, N.F. 1986. A província de granitos estaníferos de Goiás.Rev. Bras. Geociências, 16:19-131.

Marini, O. J., Botelho, N. F., Rossi, P. 1992. Elementos terras raras em granitóides da Província Estanífera de Goiás. Rev. Bras. Geoc., 22: 61-72. 
Marini, O. J., Fuck, R. A.; Danni, J. C., Dardenne, M. A., Loguercio, S. O., Ramalho, R. 1984. As faixas de dobramento Brasília, Uruaçu e Paraguai-Araguaia e o Maciço Mediano de Goiás. In: Schobbenhaus, C., Diógenes, A.C., Derge, G.R., Asmos, M.G. (Coord.). Geologia do Brasil. Brasília. DNPM. p. 251-303.

Martin, R. F., De Vito, C. 2005. The patterns of enrichment in felsic pegmatites ultimately depend on tectonic setting. The Canadian Mineralogist, 43: 2027-2048.

Martins, F. A. L. 1999. Análise faciológica e estratigráfica do Paleo-Mesoproterozóico: sequiência Araí no Parque Nacional da Chapada dos Veadeiros, Goiás. Dissertação de Mestrado, Instituto de Geociências, Universidade de Brasília, Brasília, 137p.

Matsuhisa, Y., Goldsmith, J. R., Clayton, R. N. 1978. Oxygen isotopic fractionation in the system quartz-albite-anorthite-water. Geochimica et Cosmochimica Acta, 43: 11311140 .

McDougall, I. \& Harrison, T.M. 1988. Geochronology and Thermochronology by the ${ }^{40} \mathrm{Ar} /{ }^{39} \mathrm{Ar}$ Method. Oxford University Press, N.Y., 212 p.

Mello, F. M., Bilal, E. 2009. Sucuri Massif albitites from Goiás Tin Province, Brazil. Estudos Geológicos, 19(2):223-227.

Miller, C. F., Stoddard, E. F., Bradfish, L. J. 1981. Composition of plutonic muscovite: Genetic implications. Can Mineral, 19: 25-34.

Mohammad, Y. O., Maekawa, H. Lawa, F. A. 2007. Mineralogy and origin of Mlakawa albitite from Kurdistan region, northeastern Iraq. Geosphere, 3(6): 624-645.

Mohamed, A. M. 2012. Immiscibility between silicate magma and aqueous fluids in Egyptian rare-metal granites: melt and fluid inclusions study. Arab J Geosci, 6: 40214033.

Moller, P., Dulski, P., Szacki, W., Malow, G. and Riedel, E. 1988. Substitution of tin in cassiterite by tantalum, niobium, tungsten, iron and manganese. Geochimica et Cosmochimica Acta, 52: 1497-1503.

Monier, G., Robert, J. 1986. Evolution of the miscibility gap between muscovite and biotite solid solutions with incresead lithium content: An experimental study in the sistem $\mathrm{K}_{2} \mathrm{O}-\mathrm{Li}_{2} \mathrm{O}-\mathrm{MgOFeO}-\mathrm{Al}_{2} \mathrm{O}_{3}-\mathrm{SiO}_{2}-\mathrm{H}_{2} \mathrm{O}-\mathrm{HF}$ at $600^{\circ} \mathrm{C}, 2 \mathrm{Kbar} \mathrm{PH}_{2} \mathrm{O}$ : Comparison with natural lithium micas. Mineral. Mag., 50: 641-651.

Moura, L. H. A. \& Silva, N. G. C. 2005. Projeto Nova Roma-Porto Real, Subárea IX. Trabalho Final de Graduação, IG-UnB, Brasília. 147p.

Moura, M. A., Botelho, N. F., Gema R. Olivo, G. O., Kyser, K., Pontes, R. M. 2014. Genesis of the Proterozoic Mangabeira tin-indium mineralization,Central Brazil: Evidence from geology, petrology, fluid inclusionand stable isotope data. Ore Geology Reviews, 60: 36-49. 
Nachit, H. 2005. Discrimination between primary magmatic biotites, reequilibrated biotites and neoformed biotites. Geomaterials (mineralogy), 337: 1415-1420.

Nagasawa, H. 1970. Rare earth concentrations in zircon and apatite and their host dacites and granites. Earth and Planetary Sciences Letters, 9: 359-364.

Nahodilová, R., Štípská, P., Powell, R., Košler, J., Racek, M. 2012. High-Ti muscovite as a prograde relict in high pressure granulites with metamorphic Devonian zircon ages (Běstvina granulite body, Bohemian Massif): Consequences for the relamination model of subducted crust. Gondwana Research, 25: 630-648.

Nascimento, M. A. L. 2000. Petrologia do magmatismo no MSJC (RN-PB) com ênfase no plúton alcalino Caxexa. Dissertação de Mestrado, Universidade Federal do Rio Grande do Norte.

Nash,W. P., 1984. Phosphate minerals in terrestrial igneous and metamorphic rocks. In: J.O. Nriagu and P.B. Moore (Editors), Phosphate Minerals. Springer, New York, N.Y. p. 215-241.

Nakamura, N. (1974): Determination of REE, Ba, Fe, Mg, Na and K in carbonaceous and ordinary chondrites. Geochim. Cosmochim. Acta, 38: 757-775.

Neiva, A. M. R. 1996. Geochemistry of cassiterite and its inclusions and exsolution products from tin and tungsten deposits in Portugal. The Canadian Mineralogist, 34: 745-768.

Neiva, A. M. R. 2006. Geochemistry of cassiterite and wolframite from tin and tungsten quartz veins in Portugal. Ore Geology Reviews, 33: 221-238.

Novák, M., Škoda, R., Gadas, P., Krmíček, L., Černý, P. 2012. Contrasting origins of the mixed (nyf + lct) signature in granitic pegmatites, with examples from the Moldanubian Zone, Czech Republic. The Canadian Mineralogist, 50: 1077-1094.

Nummer, A. R., Seixa, L. A. R., Machado, R. 2007. Química mineral, cristalização e deformação de granitos sintectônicos brasilianos da região de Arrozal, SW do Rio de Janeiro.Revista Brasileira de Geociências, 37(1): 202-214.

O’Neil, J. R. (1977) Stable isotope in mineralogy. Phys. Chem. Minerals 2, 105-123.

Palomba, M. 2001. Geological, mineralogical, geochemical features and genesis of the albitite deposits of central Sardinia (Italy). In: Frau F (ed) Guidebook to the field trips in Sardinia of the WRI 10, Rend Semin Fac Sci R Univ Cagliari LXXI (2):35-57 (Special issue).

Pearce, J. A. (1982). Trace element characteristics of lavas from destructive plate boundaries. In: Thorpe R.S. (ed.) Andesites: Orogenic Andesites and Related Rocks. John Wiley \& Sons, Chichester, pp. 525-548. 
Pearce, J. A., Harris, N. W. \& Tindle, A. G. (1984). Trace element discrimination diagrams for the tectonic interpretation of granitic rocks. Journal of Petrology, 25: 956983.

Pereira, A. B. 2002. Caracterização dos Granitos e Pegmatitos Peraluminosos, Mineralizados em Sn-Ta, de Monte Alegre de Goiás. Dissertação de Mestrado, Instituto de Geociências, Universidade de Brasília, Brasília, 87p.

Pieczka, A., Szuszkiewicz, A., Szełęg, E., Nejbert, K., Łodziński, M., Ilnicki, S., Turniak, K., Banach, M., Hołub, W., Michałowski, P., Różniak, R. 2013. (Fe,Mn)$(\mathrm{Ti}, \mathrm{Sn})-(\mathrm{Nb}, \mathrm{Ta})$ oxide assemblage in a little fractionatedportion of a mixed (NYF + LCT) pegmatite from Piława Górna, the Sowie Mts. block, SW Poland. Journal of Geosciences, 58: 91-112.

Pimentel, M. M., Botelho, N. F. 2001. Sr and Nd isotopic characteristics of 1,77-1,58 Ga rift-related granites and volcanics of the Goiás Tin Province, Central Brazil. Anais da Academia Brasileira de Ciências, 73: 263-276.

Pimentel, M. M., Fuck, R.A., Botelho, N.F., 1999. Granites and the geodynamic evolution of the Neoproterozoic Brasilia belt, central Brazil. Lithos, 46: 463-483.

Pimentel, M. M., Heaman, L., Fuck, R.A., Marini, O.J., 1991. U/Pb zircon geochronology of Precambrian tin-bearing continental type acid magmatism in central Brazil. Precambrian Res. 52: 321-335.

Pimentel, M. M., Jost, H., Fuck, R. A. 2004. O embasamento da Faixa Brasília e o Arco Magmático de Goiás. In: MANTESSO-NETO, V. et al. (Eds.). Geologia do Continente Sul Americano: evolução da obra de Fernando Flávio Marques de Almeida. São Paulo: Beca, p. 356-368.

Pin, C., Monchoux, P., Paquette, J. L., Zambre, B. A., Wang, R. C., Martin, R. F. 2006. Igneous albitite dikes in orogenic lherzolites, Western Pyrénées, France: a possible source for corundumand alkali feldspar xenocrysts in basaltic terranes. II. Geochemical and Petrogenetic considerations. The Canadian Mineralogist, 44: 843-856.

Polito, P. A., Kyser, T. K., Stanley, C. 2007. The Proterozoic, albitite-hosted, Valhalla uranium deposit, Queensland, Australia: a description of the alteration assemblage associated with uranium mineralization in diamond drill hole V39. Miner Deposita, 44: 11-40.

Prates, S. P., Fuzikawa, K. Aspectos petrográficos da Jazida Cachoeira. Belo Horizonte: Nuclebrás, 1985. (Nota Técnica).

Raimbault, L., Cuney, M., Azencott, C., Duthou, J.L., Joron, J.L., 1995. Multistage magmatic genesis of a Ta-Sn-Li mineralized granite at Beauvoir, French Massif Central: a geochemical study. Economic Geology, 90: 548-576.

Roddick J. C. 1983. High precision intercalibration of ${ }^{40} \mathrm{Ar} /{ }^{39} \mathrm{Ar}$ standards. Geochimica et Cosmochimica Acta, 47:887-898. 
Rollinson, H. 1993. Using geochemical data: evaluation, presentation, interpretation. Longman/Wiley, London/New York, p 352.

Rossi, P., Andrade, G. F., Cocherie, A., 1992. The 1.58 Ga A-type granite of Serra da Mesa (GO): an example of 'NYF' fertile granite pegmatite. Res. Expand. 37th Cong. Bras. Geol., SBG, São Paulo, pp. 389-390.

Rugless, C. S., \& Pirajno, F. 1996. Geology and geochemistry of the copperhead albitite "carbonate" complex, east Kimberley, Western Australia. Australian Journal of Earth Sciences, 43(3): 311-322.

Schwartz, M. O., 1992. Geochemical criteria for distinguishing magmatic and metasomatic albite-enrichment in granitoids: examples from the Ta-Li granite Yichun (China) and the Sn-W deposit Tikus (Indonesia). Miner Depos, 27:101-108.

Schwartz, M. O., Rajah, S.S., Askury, A.K., Putthapiban, P., Djaswadi, S. 1995. The Southeast Asian Tin Belt. Earth Sci Rev, 38: 95-293.

Sha, L. K. \& Chappell, B. W. 1999. Apatite chemical composition determined by electron microprobe and laser - ablation inductively coupled plasma mass spectrometry, as a probe into granite petrogenesis. Geochimica et Cosmochimica Acta, 63: 38613881 .

Shand, S. J. 1943. Eruptive rocks, their genesis, composition, and their relation to oredeposits with a chapter on meteorite. New York.

Singh, Y., Viswanathan, R., Parihar, P. S., and Maithani, P. B. 2013. X-Ray crystallography of uraninites associated with the albitite belt of western India: Evidence for the high-temperature origin of uranium and associated mineralization. Journal Geological Society of India, 81(1): 79-90.

Souza, V. S., \& Botelho, N. F. 2009. Composição química e isótopos de oxigênio em cassiterita e wolframita nos greisens do albita granito Palanqueta, depósito de estanho de Bom Futuro (RO). Revista Brasileira de Geociências, 39(4): 695-704.

Streckeisen, A. 1976. To each plutonic rocks its proper name. Earth Sci. Rev., 12: 1-33.

Steiger R.H. \& Jäger E.1977. Subcommission on geochronology: Convention on the use of decay constants in geo- and cosmo-chronology. Earth and Planetary Science Letters, 36:359-362.

Sun, T, Chen, P. R., Zhou, X. M. 2002. Strongly peraluminous granites in Eastern Nanling Mountains, China: Study on muscovites. Geol Rev (in Chinese), 48: 518-525.

Sun, S. S., and McDonough, W. F. 1989. Chemical and isotopic systematics of oceanic basalts : implications of mantle composition and processes. In: SAUNDERS, A.D.; NORRY, M.J., ed. Magmatism in the Ocean Basins. London: Geol. Soc, p.313-345. (Geol. Soc. Spec. Publ.). 
Taylor Jr. H. P. 1974. The application of oxygen and hydrogen isotope studies to problems of hydrothermal alteration and ore deposition. Econ. Geol., 69:843-883.

Taylor, H. P. \& Sheppard, S. M. F., 1986. Igneous rocks I: processes of isotopic fractionation and isotopic systematics. In: Valley, J. W., Taylor, H. P. \& O’Neill, J. R. (eds.) Stable Isotopes in High Temperature Geological Processes, Reviews in Mineralogy 16. Washington, D.C.: Mineralogical Society of America, p. 227-271.

Tao, J. H, Li, W. X, Cai, Y. F. 2014. Mineralogical feature and geological significance of muscovites from the Longyuanba Indosinian and Yanshannian two-mica granites in the eastern Nanling Range. Science China: Earth Sciences.

Teixeira, L. M. 2002. Caracterização de minerais portadores de terras raras e sua aplicação à petrologia e geocronologia de granitos das Sobprovíncias Tocantins e Paranã - Goiás. Tese de Doutorado, Instituto de Geociências, Universidade de Brasília, Brasília, 337p.

Thiéblemont, D.; Cabanis, B . Utilisation d'un diagramme (Rb/100)-Tb-Ta pour La discrimination géochimique et Pétude pétrogénétique des roches magmatiques acides. Bull.Soc. geól. France, v. 8, t.VI. n.1, p.23-35, 1990.

Tindle, A. G., Webb, P.C. 1990. Estimation of lithium contents in trioctahedral micas using microprobe data: application to micas from granitic rocks. European Journal of Mineralogy, 2: 595-610.

Tischendorf, G., 1977. Geochemical and petrographic characteristics of silicic magmatic rocks associated with rare element mineralization. In: Stemprok, M., Burnol, L., and Tischendorf, G., eds., Symposium, Metallization Associated with Acid Magmatism (MAWAM): Prague Geological Survey, 2: 41-96.

Trabalho Final de Graduação. 2005. Mapa Geologico do Projeto Nova Roma - Porto Real. Universidade de Brasília.

Troll, V. R., Deegan, F. M., Jolis, E. M., Harris, C., Chadwick, J. P., Gertisser, R., Schwarzkopf, L. M., Borisova, A. Y.,Bindeman, I. N., Sumarti, S., Preece, K. 2013. Magmatic differentiation processes at Merapi Volcano: inclusion petrology and oxygen isotopes. Journal of Volcanology and Geothermal Research. 261: 38-49.

Viana, R. R., Jordt-Evangelista, H., Stern, W.B. 2007. Geochemistry of muscovite from pegmatites of the Eastern Brazilian pegmatite province: a clue to petrogenesis and mineralization potential. Eur. J. Mineral, 19: 745-755.

Wang, G., Wang, Z., Zhang, Y., Wang, K. 2014. Zircon Geochronology and Trace element Geochemistry from the Xiaozhen Copper Deposit, North Daba Mountain: Constraints on albitites Petrogenesis. Acta Geologica Sinica (English Edition), 88(1): 113-127. 
Yin, L., Pollard, P. j., Shouxi, H. Taylor, R. G. 1995. Geologic and Geochemical Characteristics the Yichun Ta-Nb-Li Deposit, Jiangxi Province South China. EconomicGeology. 90: 577-585.

Zane, A. \& Rizzo, G. 1999. The compositional space of muscovite in granitic rocks. The Canadian Mineralogist, 37: 1229-1238.

Zhao, K. D., Jiang, S. Y., Jiang, Y. H., Wang, R. C. 2005. Mineral chemistry of the Qitianling granitoid and the Furong tin ore deposit in Hunan Province, South China: implication for the genesis of granite and related tin mineralization. Eur. J. Mineral, 17: 635-648.

Zhang, B. T.; Wu, J. Q.; Ling, H. F. 2010. Petrological discrimination between primary and secondary muscovites and its geological implications: A case study of Fuchen peraluminous granite pluton in southern Jiangxi. Acta Petrol Et Mineral (in Chinese), 29:225-234.

Zhao, Z. F.; Zheng, Y. F. 2003. Calculation of oxygen isotope fractionation in magmatic rocks. Chemical Geology 193: 59-80.

Zheng, Y. F. 1991. Calculation of oxygen isotope fractionation in metal oxides. Geochimica et Cosmochimica Acta, 55: 2299-2307.

Zhu, J. C., Li, R.K., Li, F. C, Xiong, X. L., Zhou, F. Y., Huang, X. L. 2001. Topazalbite granites and rare-metal mineralization in the Limu district, Guangxi Province, southeast China. Mineralium Deposita, 36: 393-405. 
Rochas albitizadas e albititos relacionados a mineralizações de estanho da Província Estanífera de Goiás: caracterização petrológica e gênese.

\section{ANEXO 01 \\ QUÍMICA MINERAL \\ DA ALBITA}




\begin{tabular}{|c|c|c|c|c|c|c|c|c|c|c|c|c|c|c|c|c|}
\hline \multicolumn{14}{|c|}{ ALBITITO (BOA VISTA E PELOTAS) } & \multicolumn{3}{|c|}{$\begin{array}{l}\text { BIOTITA-MUSCOVITA } \\
\text { MONZOGRANITO }\end{array}$} \\
\hline AMOSTRA & PA1I & PA1I & PA1I & PA1I & PA1I & PA1I & PA1I & PA1b & PA1b & PA1b & PA1b & PA1b & $\begin{array}{c}\text { FPS-2-7- } \\
30,70\end{array}$ & $\begin{array}{c}\text { FPS-1-9- } \\
35,44\end{array}$ & $\begin{array}{c}\text { FPS-1-9- } \\
35,44\end{array}$ & $\begin{array}{r}\text { FPS-1- } \\
9-35,44\end{array}$ \\
\hline ANÁLISE & $1 . n$ & $1 . b$ & $2 . n$ & $2 . b$ & Inc.n & Inc. b & $3 . n$ & 1 & 2 & 3 & 4 & 5 & $4 . n$ & 1 & 2 & 3 \\
\hline $\mathrm{SiO} 2$ & 71,088 & 72,062 & 72,179 & 72,554 & 71,688 & 71,333 & 72,293 & 70,81 & 70,319 & 69,715 & 70,539 & 70,085 & 69,855 & 64,618 & 62,206 & 61,401 \\
\hline $\mathrm{Al} 2 \mathrm{O} 3$ & 17,404 & 18,158 & 17,489 & 17,995 & 17,721 & 17,329 & 17,829 & 17,702 & 17,627 & 17,479 & 17,769 & 17,593 & 17,399 & 21,893 & 23,899 & 23,894 \\
\hline $\mathrm{Na} 2 \mathrm{O}$ & 12,466 & 12,55 & 13,013 & 12,81 & 12,678 & 12,582 & 12,852 & 12,617 & 12,647 & 12,771 & 12,621 & 12,273 & 12,088 & 10,801 & 9,885 & 9,272 \\
\hline $\mathrm{K} 2 \mathrm{O}$ & 0,094 & 0,123 & 0,112 & 0,087 & 0,054 & 0,098 & 0,04 & 0,123 & 0,106 & 0,123 & 0,133 & 0,158 & 0,067 & 0,087 & 0,119 & 0,083 \\
\hline $\mathrm{CaO}$ & 0,161 & 0,612 & 0,16 & 0,134 & 0,127 & 0,023 & 0,23 & 0,115 & 0,087 & 0,134 & 0,083 & 0,225 & 0,147 & 2,302 & 4,001 & 4,201 \\
\hline $\mathrm{MgO}$ & 0,012 & 0 & 0,007 & 0,029 & 0 & 0 & 0,002 & 0 & 0 & 0 & 0 & 0 & 0 & 0,006 & 0,001 & 0 \\
\hline $\mathrm{BaO}$ & 0,104 & 0 & 0 & 0 & 0,06 & 0 & 0 & 0,037 & 0,052 & 0,001 & 0,127 & 0,015 & 0 & 0 & 0 & 0,07 \\
\hline $\mathrm{TiO} 2$ & 0 & 0 & 0,015 & 0 & 0 & 0 & 0,042 & 0,037 & 0 & 0 & 0,016 & 0 & 0 & 0 & 0 & 0 \\
\hline $\mathrm{Cr} 2 \mathrm{O} 3$ & 0 & 0,014 & 0 & 0 & 0,001 & 0 & 0,019 & 0,034 & 0,022 & 0 & 0 & 0,025 & 0,047 & 0 & 0 & 0 \\
\hline $\mathrm{SrO}$ & 0 & 0,054 & 0 & 0,019 & 0 & 0,109 & 0,035 & 0 & 0,044 & 0,068 & 0 & 0,089 & 0,003 & 0 & 0,301 & 0,326 \\
\hline $\mathrm{FeO}$ & 0,048 & 0 & 0,005 & 0,019 & 0,017 & 0,038 & 0,012 & 0 & 0 & 0,038 & 0 & 0 & 0,031 & 0,007 & 0,125 & 0,049 \\
\hline $\mathrm{MnO}$ & 0,017 & 0 & 0 & 0 & 0,026 & 0,001 & 0 & 0,031 & 0 & 0 & 0,026 & 0 & 0,008 & 0,024 & 0 & 0 \\
\hline $\mathrm{V} 2 \mathrm{O} 3$ & 0 & 0,047 & 0,018 & 0,028 & 0 & 0 & 0,08 & 0 & 0,036 & 0,039 & 0 & 0,008 & 0 & 0 & 0 & 0,072 \\
\hline $\mathrm{Cl}$ & 0 & 0,02 & 0 & 0,019 & 0,015 & 0,003 & 0,002 & 0 & 0 & 0 & 0 & 0 & 0,007 & n.a & n.a & n.a \\
\hline Total & 101,394 & 103,59 & 102,998 & 103,69 & 102,384 & 101,515 & 103,436 & 101,506 & 100,94 & 100,368 & 101,314 & 100,471 & 99,65 & 99,738 & 100,537 & 99,368 \\
\hline \multicolumn{17}{|c|}{ FÓRMULA CALCULADA COM BASE EM 8 OXIGÊNIOS } \\
\hline $\mathrm{Si}$ & 3,0679 & 3,0472 & 3,0683 & 3,0607 & 3,0632 & 3,0734 & 3,0592 & 3,0541 & 3,0518 & 3,0468 & 3,0504 & 3,0537 & 3,0625 & 2,8566 & 2,7511 & 2,7453 \\
\hline $\mathrm{Al}$ & 0,8852 & 0,9049 & 0,8762 & 0,8947 & 0,8924 & 0,8799 & 0,8892 & 0,8998 & 0,9016 & 0,9003 & 0,9056 & 0,9034 & 0,8990 & 1,1406 & 1,2457 & 1,2591 \\
\hline Sitio B & 3,9531 & 3,9522 & 3,9445 & 3,9554 & 3,9556 & 3,9533 & 3,9484 & 3,9539 & 3,9534 & 3,9471 & 3,9560 & 3,9571 & 3,9615 & 3,9972 & 3,9969 & 4,0043 \\
\hline $\mathrm{Na}$ & 1,0431 & 1,0252 & 1,0725 & 1,0477 & 1,0503 & 1,0510 & 1,0544 & 1,0551 & 1,0642 & 1,0821 & 1,0582 & 1,0368 & 1,0275 & 0,9257 & 0,8476 & 0,8037 \\
\hline $\mathrm{K}$ & 0,0052 & 0,0066 & 0,0061 & 0,0047 & 0,0029 & 0,0054 & 0,0022 & 0,0068 & 0,0059 & 0,0069 & 0,0073 & 0,0088 & 0,0037 & 0,0049 & 0,0067 & 0,0047 \\
\hline $\mathrm{Ca}$ & 0,0074 & 0,0277 & 0,0073 & 0,0061 & 0,0058 & 0,0011 & 0,0104 & 0,0053 & 0,0040 & 0,0063 & 0,0038 & 0,0105 & 0,0069 & 0,1090 & 0,1896 & 0,2012 \\
\hline Sitio A & 1,0557 & 1,0596 & 1,0859 & 1,0585 & 1,0591 & 1,0575 & 1,0670 & 1,0671 & 1,0741 & 1,0953 & 1,0694 & 1,0561 & 1,0381 & $\begin{array}{l}1,0397 \\
\end{array}$ & 1,0439 & 1,0097 \\
\hline $\mathrm{Mg}$ & 0,0008 & 0,0000 & 0,0004 & 0,0018 & 0,0000 & 0,0000 & 0,0001 & 0,0000 & 0,0000 & 0,0000 & 0,0000 & 0,0000 & 0,0000 & 0,0004 & 0,0001 & 0,0000 \\
\hline $\mathrm{Ba}$ & 0,0018 & 0,0000 & 0,0000 & 0,0000 & 0,0010 & 0,0000 & 0,0000 & 0,0006 & 0,0009 & 0,0000 & 0,0022 & 0,0003 & 0,0000 & 0,0000 & 0,0000 & 0,0012 \\
\hline $\mathrm{Ti}$ & 0,0000 & 0,0000 & 0,0005 & 0,0000 & 0,0000 & 0,0000 & 0,0013 & 0,0012 & 0,0000 & 0,0000 & 0,0005 & 0,0000 & 0,0000 & 0,0000 & 0,0000 & 0,0000 \\
\hline $\mathrm{Cr}$ & 0,0000 & 0,0005 & 0,0000 & 0,0000 & 0,0000 & 0,0000 & 0,0006 & 0,0012 & 0,0008 & 0,0000 & 0,0000 & 0,0009 & 0,0016 & 0,0000 & 0,0000 & 0,0000 \\
\hline $\mathrm{Sr}$ & 0,0000 & 0,0013 & 0,0000 & 0,0005 & 0,0000 & 0,0027 & 0,0009 & 0,0000 & 0,0011 & 0,0017 & 0,0000 & 0,0022 & 0,0001 & 0,0000 & 0,0077 & 0,0085 \\
\hline $\mathrm{Fe}$ & 0,0017 & 0,0000 & 0,0002 & 0,0007 & 0,0006 & 0,0014 & 0,0004 & 0,0000 & 0,0000 & 0,0014 & 0,0000 & 0,0000 & 0,0011 & 0,0003 & 0,0046 & 0,0018 \\
\hline $\mathrm{Mn}$ & 0,0006 & 0,0000 & 0,0000 & 0,0000 & 0,0009 & 0,0000 & 0,0000 & 0,0011 & 0,0000 & 0,0000 & 0,0010 & 0,0000 & 0,0003 & 0,0009 & 0,0000 & 0,0000 \\
\hline V & 0,0000 & 0,0016 & 0,0006 & 0,0009 & 0,0000 & 0,0000 & 0,0027 & 0,0000 & 0,0013 & 0,0014 & 0,0000 & 0,0003 & 0,0000 & 0,0000 & 0,0000 & 0,0026 \\
\hline $\mathrm{Cl}$ & 0,0000 & 0,0014 & 0,0000 & 0,0014 & 0,0011 & 0,0002 & 0,0001 & 0,0000 & 0,0000 & 0,0000 & 0,0000 & 0,0000 & 0,0005 & 0,0000 & 0,0000 & 0,0000 \\
\hline TOTAL & 5,0136 & 5,0166 & 5,0321 & 5,0191 & 5,0183 & 5,0151 & 5,0216 & 5,0252 & 5,0314 & 5,0469 & 5,0290 & 5,0168 & 5,0033 & 5,0384 & 5,0532 & 5,0281 \\
\hline$\% \mathrm{An}$ & 0,7052 & 2,6167 & 0,6711 & 0,5722 & 0,5490 & 0,1004 & 0,9773 & 0,4980 & 0,3766 & 0,5729 & 0,3596 & 0,9946 & 0,6651 & 10,4868 & 18,1609 & 19,9301 \\
\hline$\% \mathrm{Ab}$ & 98,8046 & 96,7571 & 98,7696 & 98,9855 & 99,1731 & 99,3902 & 98,8204 & 98,8678 & 99,0770 & 98,8010 & 98,9543 & 98,1738 & 98,9739 & 89,0413 & 81,1960 & 79,6011 \\
\hline$\%$ Or & 0,4902 & 0,6262 & 0,5593 & 0,4423 & 0,2779 & 0,5094 & 0,2024 & 0,6342 & 0,5464 & 0,6261 & 0,6861 & 0,8316 & 0,3610 & 0,4719 & 0,6432 & 0,4689 \\
\hline
\end{tabular}




\begin{tabular}{|c|c|c|c|c|c|c|c|c|c|c|c|c|c|c|c|c|}
\hline \multicolumn{12}{|c|}{ BIOTITA-MUSCOVITA MONZOGRANITO } & \multicolumn{5}{|c|}{ BIOTITA-MUSCOVITA TONALITO } \\
\hline AMOSTRA & $\begin{array}{c}\text { FPS-1-9- } \\
35,44 \\
\end{array}$ & $\begin{array}{c}\text { FPS-1-9- } \\
35,44 \\
\end{array}$ & $\begin{array}{c}\text { FPS-8-9- } \\
39,02 \\
\end{array}$ & $\begin{array}{c}\text { FPS-8-9- } \\
39,02 \\
\end{array}$ & $\begin{array}{c}\text { FPS-8-9- } \\
39,02 \\
\end{array}$ & $\begin{array}{c}\text { FPS-8-9- } \\
39,02 \\
\end{array}$ & $\begin{array}{c}\text { FPS-8-8- } \\
36,40 \\
\end{array}$ & $\begin{array}{c}\text { FPS-8-8- } \\
36,40 \\
\end{array}$ & $\begin{array}{c}\text { FPS-8-8- } \\
36,40 \\
\end{array}$ & $\begin{array}{c}\text { FPS-8-8- } \\
36,40 \\
\end{array}$ & $\begin{array}{c}\text { FPS-8-8- } \\
36,40 \\
\end{array}$ & $\begin{array}{c}\text { FPS-5-7- } \\
28,05 \\
\end{array}$ & $\begin{array}{c}\text { FPS-5-7- } \\
28,05 \\
\end{array}$ & $\begin{array}{c}\text { FPS-5-7- } \\
28,05 \\
\end{array}$ & $\begin{array}{c}\text { FPS-5-7- } \\
28,05 \\
\end{array}$ & $\begin{array}{c}\text { FPS-5-7- } \\
28,05 \\
\end{array}$ \\
\hline ANÁLISE & 4 & 5 & 1 & 2 & 3 & 4 & 1 & 2 & 3 & 4 & 5 & 2 & 4 & 5 & 7 & 10 \\
\hline $\mathrm{SiO} 2$ & 62,543 & 61,357 & 67,753 & 66,836 & 67,579 & 67,608 & 66,569 & 63,604 & 66,64 & 67,46 & 67,48 & 66,259 & 67,144 & 66,303 & 63,428 & 64,902 \\
\hline $\mathrm{Al} 2 \mathrm{O} 3$ & 23,861 & 24,478 & 20,447 & 20,484 & 20,469 & 20,382 & 21,737 & 20,003 & 20,622 & 20,179 & 20,289 & 20,341 & 20,713 & 21,151 & 22,465 & 21,7 \\
\hline $\mathrm{Na} 2 \mathrm{O}$ & 9,813 & 9,319 & 12,106 & 12,062 & 12,302 & 12,497 & 11,368 & 11,019 & 12,132 & 12,327 & 12,279 & 11,905 & 11,951 & 11,336 & 10,586 & 10,892 \\
\hline $\mathrm{K} 2 \mathrm{O}$ & 0,095 & 0,087 & 0,069 & 0,072 & 0,061 & 0,031 & 0,066 & 0,223 & 0,067 & 0,04 & 0,06 & 0,073 & 0,074 & 0,082 & 0,086 & 0,086 \\
\hline $\mathrm{CaO}$ & 4,15 & 4,815 & 0,105 & 0,219 & 0,159 & 0,161 & 1,533 & 0,728 & 0,887 & 0,4 & 0,197 & 0,512 & 0,571 & 1,244 & 2,814 & 1,919 \\
\hline $\mathrm{MgO}$ & 0 & 0 & 0,007 & 0 & 0 & 0 & 0 & 0,044 & 0,01 & 0 & 0 & 0 & 0 & 0,018 & 0,025 & 0 \\
\hline $\mathrm{BaO}$ & 0 & 0 & 0,095 & 0 & 0,047 & 0,035 & 0,07 & 0,094 & 0 & 0 & 0,011 & 0,07 & 0 & 0,071 & 0,036 & 0,07 \\
\hline TiO2 & 0 & 0 & 0,016 & 0 & 0 & 0,009 & 0 & 0 & 0 & 0 & 0,031 & 0 & 0,014 & 0 & 0 & 0 \\
\hline $\mathrm{Cr} 2 \mathrm{O} 3$ & 0,037 & 0 & 0 & 0,016 & 0 & 0 & 0,026 & 0 & 0 & 0,004 & 0 & 0 & 0,012 & 0,031 & 0,01 & 0,035 \\
\hline $\mathrm{SrO}$ & 0,007 & 0,293 & 0,062 & 0,069 & 0,107 & 0,107 & 0 & 0 & 0 & 0,1 & 0 & 0,102 & 0,007 & 0,053 & 0,063 & 0 \\
\hline $\mathrm{FeO}$ & 0,086 & 0,034 & 0,018 & 0,014 & 0,049 & 0,056 & 0,055 & 0,098 & 0 & 0 & 0,004 & 0,003 & 0,019 & 0 & 0 & 0,015 \\
\hline $\mathrm{MnO}$ & 0 & 0,019 & 0,013 & 0 & 0,001 & 0 & 0,036 & 0,029 & 0 & 0,007 & 0,03 & 0 & 0,025 & 0 & 0,011 & 0 \\
\hline $\mathrm{V} 2 \mathrm{O} 3$ & 0,061 & 0,013 & 0,046 & 0 & 0 & 0 & 0,072 & 0 & 0 & 0 & 0 & 0 & 0,02 & 0 & 0,007 & 0 \\
\hline $\mathrm{Cl}$ & n.a & n.a & n.a & n.a & n.a & n.a & n.a & n.a & n.a & n.a & n.a & n.a & n.a & n.a & n.a & n.a \\
\hline Total & 100,653 & 100,415 & 100,737 & 99,772 & 100,774 & 100,886 & 101,532 & 95,842 & $\begin{array}{l}100,358 \\
\end{array}$ & 100,517 & $\begin{array}{l}100,381 \\
\end{array}$ & 99,265 & 100,55 & 100,289 & 99,531 & 99,619 \\
\hline \multicolumn{17}{|c|}{ FORMULA CALCULADA COM BASE EM 8 OXIGÊNIOS } \\
\hline $\mathrm{Si}$ & 2,7570 & 2,7199 & 2,9500 & 2,9390 & 2,9446 & 2,9444 & 2,8866 & 2,9179 & 2,9211 & 2,9480 & 2,9490 & 2,9334 & 2,9312 & 2,9065 & 2,8187 & 2,8699 \\
\hline $\mathrm{Al}$ & 1,2397 & 1,2789 & 1,0493 & 1,0616 & 1,0512 & 1,0462 & 1,1109 & 1,0815 & 1,0654 & 1,0393 & 1,0450 & 1,0613 & 1,0657 & 1,0928 & 1,1766 & 1,1309 \\
\hline Sitio B & 3,9966 & 3,9988 & 3,9993 & 4,0006 & 3,9957 & 3,9906 & 3,9975 & 3,9994 & 3,9865 & 3,9873 & 3,9940 & 3,9947 & 3,9970 & 3,9993 & 3,9953 & 4,0008 \\
\hline $\mathrm{Na}$ & 0,8387 & 0,8009 & 1,0220 & 1,0284 & 1,0393 & 1,0552 & 0,9557 & 0,9801 & 1,0311 & 1,0444 & 1,0404 & 1,0219 & 1,0115 & 0,9635 & 0,9121 & 0,9338 \\
\hline $\mathrm{K}$ & 0,0053 & 0,0049 & 0,0038 & 0,0040 & 0,0034 & 0,0017 & 0,0037 & 0,0131 & 0,0037 & 0,0022 & 0,0033 & 0,0041 & 0,0041 & 0,0046 & 0,0049 & 0,0049 \\
\hline $\mathrm{Ca}$ & 0,1960 & 0,2287 & 0,0049 & 0,0103 & 0,0074 & 0,0075 & 0,0712 & 0,0358 & 0,0417 & 0,0187 & 0,0092 & 0,0243 & 0,0267 & 0,0584 & 0,1340 & 0,0909 \\
\hline Sitio A & 1,0400 & 1,0346 & 1,0307 & 1,0427 & 1,0501 & 1,0645 & 1,0306 & 1,0289 & 1,0765 & 1,0654 & 1,0530 & 1,0503 & 1,0424 & 1,0265 & 1,0509 & 1,0296 \\
\hline $\mathrm{Mg}$ & 0,0000 & 0,0000 & 0,0005 & 0,0000 & 0,0000 & 0,0000 & 0,0000 & 0,0030 & 0,0007 & 0,0000 & 0,0000 & 0,0000 & 0,0000 & 0,0012 & 0,0017 & 0,0000 \\
\hline $\mathrm{Ba}$ & 0,0000 & 0,0000 & 0,0016 & 0,0000 & 0,0008 & 0,0006 & 0,0012 & 0,0017 & 0,0000 & 0,0000 & 0,0002 & 0,0012 & 0,0000 & 0,0012 & 0,0006 & 0,0012 \\
\hline $\mathrm{Ti}$ & 0,0000 & 0,0000 & 0,0005 & 0,0000 & 0,0000 & 0,0003 & 0,0000 & 0,0000 & 0,0000 & 0,0000 & 0,0010 & 0,0000 & 0,0005 & 0,0000 & 0,0000 & 0,0000 \\
\hline $\mathrm{Cr}$ & 0,0013 & 0,0000 & 0,0000 & 0,0006 & 0,0000 & 0,0000 & 0,0009 & 0,0000 & 0,0000 & 0,0001 & 0,0000 & 0,0000 & 0,0004 & 0,0011 & 0,0004 & 0,0012 \\
\hline $\mathrm{Sr}$ & 0,0002 & 0,0075 & 0,0016 & 0,0018 & 0,0027 & 0,0027 & 0,0000 & 0,0000 & 0,0000 & 0,0025 & 0,0000 & 0,0026 & 0,0002 & 0,0013 & 0,0016 & 0,0000 \\
\hline $\mathrm{Fe}$ & 0,0032 & 0,0013 & 0,0007 & 0,0005 & 0,0018 & 0,0020 & 0,0020 & 0,0038 & 0,0000 & 0,0000 & 0,0001 & 0,0001 & 0,0007 & 0,0000 & 0,0000 & 0,0006 \\
\hline $\mathrm{Mn}$ & 0,0000 & 0,0007 & 0,0005 & 0,0000 & 0,0000 & 0,0000 & 0,0013 & 0,0011 & 0,0000 & 0,0003 & 0,0011 & 0,0000 & 0,0009 & 0,0000 & 0,0004 & 0,0000 \\
\hline $\mathrm{V}$ & 0,0022 & 0,0005 & 0,0016 & 0,0000 & 0,0000 & 0,0000 & 0,0025 & 0,0000 & 0,0000 & 0,0000 & 0,0000 & 0,0000 & 0,0007 & 0,0000 & 0,0002 & 0,0000 \\
\hline $\mathrm{Cl}$ & n.a & n.a & n.a & n.a & n.a & n.a & n.a & n.a & n.a & n.a & n.a & n.a & n.a & n.a & n.a & n.a \\
\hline TOTAL & 5,0435 & 5,0433 & 5,0369 & 5,0461 & 5,0512 & 5,0607 & 5,0360 & 5,0379 & 5,0636 & 5,0556 & 5,0494 & 5,0489 & 5,0427 & 5,0306 & 5,0512 & 5,0334 \\
\hline$\% \mathrm{An}$ & 18,8457 & 22,1049 & 0,4752 & 0,9895 & 0,7069 & 0,7057 & 6,9106 & 3,4776 & 3,8698 & 1,7579 & 0,8760 & 2,3123 & 2,5622 & 5,6919 & 12,7485 & 8,8304 \\
\hline$\% \mathrm{Ab}$ & 80,6407 & 77,4195 & 99,1529 & 98,6232 & 98,9702 & 99,1325 & 92,7352 & 95,2540 & 95,7822 & 98,0328 & $\begin{array}{l}98,8063 \\
\end{array}$ & 97,2952 & 97,0425 & 93,8614 & 86,7876 & 90,6985 \\
\hline$\%$ Or & 0,5137 & 0,4756 & 0,3718 & 0,3874 & 0,3229 & 0,1618 & 0,3543 & 1,2684 & 0,3480 & 0,2093 & 0,3177 & 0,3926 & 0,3954 & 0,4467 & 0,4639 & 0,4712 \\
\hline
\end{tabular}




\section{ANEXO 02 \\ QUÍMICA MINERAL \\ DA MUSCOVITA}




\begin{tabular}{|c|c|c|c|c|c|c|c|c|c|c|c|c|c|c|c|c|}
\hline \multicolumn{17}{|c|}{ ALBITITO (BOA VISTA) } \\
\hline AMOSTRA & PA1I & PA1I & PA1I & PA1I & PA1I & PA1I & PA1I & PA1I & PA1I & PA1I & PA1I & PA1I & PA1b & PA1b & PAlb & PA1b \\
\hline ANÁLISE & $1 . \mathrm{n}$ & $1 . \mathrm{b}$ & $2 . n$ & 2.b & $3 . n$ & $3 . b$ & $4 . n$ & 4.b & $5 . n$ & 5.b & $6 . n$ & 6.b & $1 . \mathrm{n}$ & 1.b & $2 . n$ & $2 . \mathrm{b}$ \\
\hline $\mathrm{SiO} 2$ & 48,363 & 47,313 & 47,739 & 47,7 & 47,398 & 47,176 & 47,385 & 48,4 & 46,911 & 47,306 & 47,948 & 47,696 & 45,363 & 47,74 & 46,368 & 47,138 \\
\hline TiO2 & 0,032 & 0,02 & 0 & 0,017 & 0,041 & 0,011 & 0,046 & 0,069 & 0,011 & 0 & 0 & 0 & 0 & 0 & 0,006 & 0 \\
\hline $\mathrm{Al} 2 \mathrm{O} 3$ & 32,809 & 32,713 & 32,644 & 33,787 & 32,688 & 33,345 & 32,548 & 33,666 & 32,784 & 32,375 & 32,462 & 33,157 & 32,273 & 27,957 & 32,541 & 32,795 \\
\hline $\mathrm{FeO}$ & 0,868 & 0,811 & 0,895 & 0,932 & 0,845 & 0,836 & 1,033 & 0,862 & 0,669 & 0,86 & 0,8 & 0,848 & 0,83 & 3,394 & 0,689 & 0,693 \\
\hline $\mathrm{MnO}$ & 0,015 & 0,027 & 0,015 & 0,058 & 0,011 & 0,021 & 0,059 & 0,023 & 0,047 & 0 & 0,089 & 0 & 0,055 & 0,149 & 0,027 & 0,061 \\
\hline $\mathrm{MgO}$ & 0,063 & 0,062 & 0,082 & 0,023 & 0,084 & 0,092 & 0,037 & 0,105 & 0,09 & 0,133 & 0,114 & 0,11 & 0,015 & 0,225 & 0,027 & 0,035 \\
\hline $\mathrm{CaO}$ & 0,042 & 0,041 & 0 & 0,057 & 0,052 & 0,023 & 0,031 & 0,004 & 0,06 & 0,036 & 0,026 & 0,057 & 0,023 & 0,019 & 0,026 & 0,034 \\
\hline $\mathrm{Na} 2 \mathrm{O}$ & 0,804 & 0,848 & 0,798 & 0,88 & 0,584 & 0,584 & 0,434 & 0,68 & 0,626 & 0,694 & 0,639 & 0,76 & 0,98 & 0,262 & 0,958 & 0,77 \\
\hline $\mathrm{K} 2 \mathrm{O}$ & 10,503 & 10,462 & 10,161 & 10,56 & 10,664 & 10,656 & 10,478 & 10,229 & 10,638 & 9,951 & 10,354 & 10,688 & 10,305 & 10,363 & 10,734 & 10,53 \\
\hline $\mathrm{SrO}$ & 0,013 & 0,097 & 0 & 0,111 & 0,062 & 0,025 & 0 & 0 & 0 & 0 & 0,017 & 0 & 0 & 0 & 0,016 & 0 \\
\hline $\mathrm{BaO}$ & 0,024 & 0 & 0 & 0,023 & 0,023 & 0 & 0,151 & 0 & 0 & 0,037 & 0,052 & 0,136 & 0,03 & 0,009 & 0,037 & 0 \\
\hline $\mathrm{Cr} 2 \mathrm{O} 3$ & 0 & 0 & 0 & 0 & 0,022 & 0,006 & 0,016 & 0,052 & 0 & 0 & 0,005 & 0 & 0,015 & 0,014 & 0 & 0,054 \\
\hline $\mathrm{F}$ & 0,013 & 0 & 0 & 0 & 0 & 0 & 0 & 0 & 0 & 0,018 & 0,029 & 0,089 & 0,034 & 0,433 & 0,087 & 0,018 \\
\hline $\mathrm{Cl}$ & 0 & 0 & 0,005 & 0 & 0 & 0 & 0,018 & 0 & 0,007 & 0 & 0 & 0,002 & 0 & 0,012 & 0 & 0 \\
\hline $\mathrm{H} 2 \mathrm{O}^{*}$ & 4,44 & 4,38 & 4,40 & 4,46 & 4,39 & 4,40 & 4,37 & 4,49 & 4,36 & 4,35 & 4,39 & 4,39 & 4,24 & 4,02 & 4,29 & 4,37 \\
\hline Total & 97,98 & 96,78 & 96,73 & 98,61 & 96,86 & 97,18 & 96,60 & 98,58 & 96,20 & 95,75 & 96,91 & 97,89 & 94,15 & 94,41 & 95,76 & 96,49 \\
\hline \multicolumn{17}{|c|}{ FORMULA CALCULADA COM BASE EM 22 OXIGÊNIOS } \\
\hline $\mathrm{Si}$ & 6,521 & 6,470 & 6,510 & 6,409 & 6,478 & 6,424 & 6,492 & 6,470 & 6,451 & 6,511 & 6,532 & 6,455 & 6,392 & 6,771 & 6,426 & 6,461 \\
\hline $\mathrm{Al}$ iv & 1,479 & 1,530 & 1,490 & 1,591 & 1,522 & 1,576 & 1,508 & 1,530 & 1,549 & 1,489 & 1,468 & 1,545 & 1,608 & 1,229 & 1,574 & 1,539 \\
\hline Sitio T & 8,000 & 8,000 & 8,000 & 8,000 & 8,000 & 8,000 & 8,000 & 8,000 & 8,000 & 8,000 & 8,000 & 8,000 & 8,000 & 8,000 & 8,000 & 8,000 \\
\hline $\mathrm{Al}$ vi & 3,736 & 3,743 & 3,758 & 3,760 & 3,743 & 3,776 & 3,749 & 3,775 & 3,764 & 3,763 & 3,745 & 3,744 & 3,753 & 3,445 & 3,742 & 3,759 \\
\hline $\mathrm{Ti}$ & 0,003 & 0,002 & 0,000 & 0,002 & 0,004 & 0,001 & 0,005 & 0,007 & 0,001 & 0,000 & 0,000 & 0,000 & 0,000 & $\begin{array}{l}0,000 \\
\end{array}$ & 0,001 & 0,000 \\
\hline $\mathrm{Cr}$ & 0,000 & 0,000 & 0,000 & 0,000 & 0,002 & 0,001 & 0,002 & 0,005 & 0,000 & 0,000 & 0,001 & 0,000 & 0,002 & 0,002 & 0,000 & 0,006 \\
\hline $\mathrm{Fe}$ & 0,098 & 0,093 & 0,102 & 0,105 & 0,097 & 0,095 & 0,118 & 0,096 & 0,077 & 0,099 & 0,091 & 0,096 & 0,098 & 0,403 & 0,080 & 0,079 \\
\hline $\mathrm{Mn}$ & 0,007 & 0,007 & 0,009 & 0,003 & 0,010 & 0,011 & 0,007 & 0,003 & 0,005 & 0,000 & 0,010 & 0,000 & 0,007 & 0,018 & 0,003 & 0,007 \\
\hline $\mathrm{Mg}$ & 0,007 & 0,008 & 0,008 & 0,007 & 0,008 & 0,008 & 0,008 & 0,021 & 0,018 & 0,027 & 0,023 & 0,022 & 0,003 & 0,048 & 0,006 & 0,007 \\
\hline Sitio M & 3,852 & 3,853 & 3,877 & 3,876 & 3,864 & 3,891 & 3,888 & 3,907 & 3,866 & 3,889 & 3,870 & 3,863 & 3,862 & 3,914 & 3,831 & 3,859 \\
\hline $\mathrm{Ca}$ & 0,006 & 0,006 & 0,000 & 0,008 & 0,008 & 0,003 & 0,005 & 0,001 & 0,009 & 0,005 & 0,004 & 0,008 & 0,003 & 0,003 & 0,004 & 0,005 \\
\hline $\mathrm{Na}$ & 0,210 & 0,225 & 0,211 & $\begin{array}{l}0,229 \\
\end{array}$ & 0,155 & 0,154 & 0,115 & 0,176 & 0,167 & 0,185 & 0,169 & $\begin{array}{l}0,199 \\
\end{array}$ & 0,268 & 0,072 & 0,257 & 0,205 \\
\hline $\mathrm{K}$ & 1,806 & 1,825 & 1,767 & 1,810 & 1,859 & 1,851 & 1,831 & 1,744 & 1,866 & 1,747 & 1,799 & 1,845 & 1,852 & 1,875 & 1,897 & 1,841 \\
\hline $\mathrm{Sr}$ & 0,001 & 0,008 & 0,000 & 0,009 & 0,005 & 0,002 & 0,000 & 0,000 & 0,000 & 0,000 & 0,001 & 0,000 & 0,000 & 0,000 & 0,001 & 0,000 \\
\hline $\mathrm{Ba}$ & 0,001 & 0,000 & 0,000 & 0,001 & 0,001 & 0,000 & 0,008 & 0,000 & 0,000 & 0,002 & 0,003 & 0,007 & 0,002 & 0,001 & 0,002 & 0,000 \\
\hline Sitio I & 2,025 & 2,063 & 1,979 & 2,057 & 2,027 & 2,010 & 1,959 & $\begin{array}{ll}1,921 \\
\end{array}$ & 2,042 & 1,939 & 1,976 & 2,060 & 2,125 & 1,950 & 2,162 & 2,051 \\
\hline $\mathrm{OH}^{*}$ & 3,994 & 4,000 & 3,999 & 4,000 & 4,000 & 4,000 & 3,996 & 4,000 & 3,998 & 3,992 & 3,988 & 3,961 & 3,985 & 3,803 & 3,962 & 3,992 \\
\hline $\mathrm{F}$ & 0,006 & 0,000 & 0,000 & 0,000 & 0,000 & 0,000 & 0,000 & 0,000 & 0,000 & 0,008 & 0,012 & 0,038 & 0,015 & 0,194 & 0,038 & 0,008 \\
\hline $\mathrm{Cl}$ & 0,000 & 0,000 & 0,001 & 0,000 & 0,000 & 0,000 & 0,004 & 0,000 & 0,002 & 0,000 & 0,000 & 0,000 & 0,000 & 0,003 & 0,000 & 0,000 \\
\hline Sitio A & 4,000 & 4,000 & 4,000 & 4,000 & 4,000 & 4,000 & 4,000 & 4,000 & 4,000 & 4,000 & 4,000 & 4,000 & 4,000 & 4,000 & 4,000 & 4,000 \\
\hline TOTAL & 31,753 & 31,832 & 31,710 & 31,867 & 31,782 & 31,802 & 31,694 & 31,656 & 31,816 & 31,658 & 31,691 & 31,845 & 31,974 & 31,729 & 31,986 & 31,819 \\
\hline
\end{tabular}




\begin{tabular}{|c|c|c|c|c|c|c|c|c|c|c|c|c|c|}
\hline \multicolumn{7}{|c|}{ ALBITITO (BOA VISTA) } & \multicolumn{7}{|c|}{ ALBITITO (PELOTAS) } \\
\hline AMOSTRA & PA1b & PA1b & PAlb & PA1b & PA1b & PA1b & $\begin{array}{c}\text { FPS-2-7- } \\
30,70 \\
\end{array}$ & $\begin{array}{c}\text { FPS-2-7- } \\
30,70 \\
\end{array}$ & $\begin{array}{c}\text { FPS-2-7- } \\
30,70 \\
\end{array}$ & $\begin{array}{c}\text { FPS-2-7- } \\
30,70 \\
\end{array}$ & $\begin{array}{c}\text { FPS-2-7- } \\
30,70 \\
\end{array}$ & $\begin{array}{c}\text { FPS-2-7- } \\
30,70 \\
\end{array}$ & $\begin{array}{c}\text { FPS-2-7- } \\
30,70 \\
\end{array}$ \\
\hline ANÁLISE & $3 . n$ & 3.b & 4.b & $4 . n$ & $5 . \mathrm{n}$ & 5.b & 3.n & $4 . n$ & 4.b & $5 . \mathrm{n}$ & 5.b & $6 . \mathrm{n}$ & 6.b \\
\hline $\mathrm{SiO} 2$ & 46,659 & 46,961 & 45,9 & 45,954 & 46,672 & 46,495 & 45,256 & 47,573 & 47,305 & 47,305 & 47,244 & 46,939 & 46,719 \\
\hline $\mathrm{TiO} 2$ & 0,015 & 0 & 0 & 0,028 & 0 & 0,021 & 0,009 & 0 & 0,025 & 0 & 0 & 0 & 0 \\
\hline $\mathrm{Al} 2 \mathrm{O} 3$ & 32,721 & 33,23 & 33,004 & 32,94 & 32,674 & 32,441 & 26,278 & 33,3 & 33,163 & 33,37 & 33,986 & 33,068 & 33,13 \\
\hline $\mathrm{FeO}$ & 0,781 & 0,639 & 0,628 & 0,782 & 0,306 & 0,917 & 0,652 & 0,621 & 0,742 & 0,657 & 0,331 & 0,754 & 0,199 \\
\hline $\mathrm{MnO}$ & 0,052 & 0,027 & 0,034 & 0,057 & 0,019 & 0,079 & 0,036 & 0,012 & 0,007 & 0,035 & 0,086 & 0,03 & 0,129 \\
\hline $\mathrm{MgO}$ & 0,028 & 0,012 & 0 & 0,023 & 0,044 & 0,038 & 0,925 & 0,066 & 0,091 & 0,036 & 0 & 0,035 & 0,003 \\
\hline $\mathrm{CaO}$ & 0,081 & 0,048 & 0,007 & 0,03 & 0,036 & 0,052 & 0,168 & 0,015 & 0,023 & 0,08 & 0,05 & 0,037 & 0 \\
\hline $\mathrm{Na} 2 \mathrm{O}$ & 0,805 & 0,842 & 0,883 & 0,952 & 0,416 & 0,945 & 0,286 & 0,82 & 0,89 & 0,773 & 0,642 & 0,905 & 0,528 \\
\hline K2O & 10,082 & 10,377 & 10,264 & 9,841 & 10,827 & 10,201 & 9,196 & 10,289 & 10,054 & 10,391 & 10,701 & 10,154 & 10,893 \\
\hline $\mathrm{SrO}$ & 0,054 & 0 & 0,038 & 0,066 & 0 & 0,03 & 0,021 & 0,124 & 0,001 & 0 & 0,022 & 0,07 & 0 \\
\hline $\mathrm{BaO}$ & 0,09 & 0 & 0 & 0,046 & 0 & 0,068 & 0,195 & 0 & 0,008 & 0,037 & 0 & 0,045 & 0 \\
\hline $\mathrm{Cr} 2 \mathrm{O} 3$ & 0 & 0,037 & 0 & 0,028 & 0 & 0,008 & 0,04 & 0,01 & 0,01 & 0 & 0,006 & 0,011 & 0,008 \\
\hline $\mathrm{F}$ & 0,054 & 0 & 0,025 & 0,04 & 0 & 0,073 & 0,289 & 0,127 & 0,166 & 0,08 & 0 & 0,118 & 0,024 \\
\hline $\mathrm{Cl}$ & 0,006 & 0,013 & 0 & 0 & 0 & 0,005 & 0,013 & 0 & 0,012 & 0 & 0,016 & 0 & 0,004 \\
\hline $\mathrm{H}^{2} \mathrm{O}^{*}$ & 4,31 & 4,38 & 4,30 & 4,29 & 4,33 & 4,29 & 3,82 & 4,36 & 4,32 & 4,37 & 4,42 & 4,32 & 4,34 \\
\hline Total & 95,72 & 96,56 & 95,07 & 95,06 & 95,32 & 95,63 & 87,06 & 97,26 & 96,74 & 97,10 & 97,50 & 96,44 & 95,97 \\
\hline \multicolumn{14}{|c|}{ FORMULA CALCULADA COM BASE EM 22 OXIGÊNIOS } \\
\hline Si & $\begin{array}{l}6,444 \\
\end{array}$ & 6,426 & 6,386 & 6,389 & 6,466 & 6,441 & 6,848 & 6,456 & 6,450 & 6,435 & 6,398 & 6,433 & 6,433 \\
\hline $\mathrm{Al}$ iv & 1,556 & 1,574 & 1,614 & 1,611 & 1,534 & 1,559 & 1,152 & 1,544 & 1,550 & 1,565 & 1,602 & 1,567 & 1,567 \\
\hline Sitio T & 8,000 & 8,000 & 8,000 & 8,000 & 8,000 & 8,000 & 8,000 & 8,000 & 8,000 & 8,000 & 8,000 & 8,000 & 8,000 \\
\hline $\mathrm{Al}$ vi & 3,771 & 3,785 & 3,798 & 3,786 & 3,802 & 3,739 & 3,534 & 3,783 & 3,779 & 3,786 & 3,823 & 3,775 & 3,811 \\
\hline $\mathrm{Ti}$ & 0,002 & 0,000 & 0,000 & 0,003 & 0,000 & 0,002 & 0,001 & 0,000 & 0,003 & 0,000 & 0,000 & 0,000 & 0,000 \\
\hline $\mathrm{Cr}$ & 0,000 & 0,004 & 0,000 & 0,003 & 0,000 & 0,001 & 0,005 & 0,001 & 0,001 & 0,000 & 0,001 & 0,001 & 0,001 \\
\hline $\mathrm{Fe}$ & 0,090 & 0,073 & 0,073 & 0,091 & 0,035 & 0,106 & 0,083 & 0,070 & 0,085 & 0,075 & 0,037 & 0,086 & 0,023 \\
\hline $\mathrm{Mn}$ & 0,006 & 0,003 & 0,004 & 0,007 & 0,002 & 0,009 & 0,005 & 0,001 & 0,001 & 0,004 & 0,010 & 0,003 & 0,015 \\
\hline $\mathrm{Mg}$ & 0,006 & 0,002 & 0,000 & 0,005 & 0,009 & 0,008 & 0,209 & 0,013 & 0,018 & 0,007 & 0,000 & 0,007 & 0,001 \\
\hline Sitio M & 3,874 & 3,868 & 3,875 & 3,895 & 3,848 & 3,865 & 3,836 & 3,869 & 3,887 & 3,872 & 3,871 & 3,874 & 3,850 \\
\hline $\mathrm{Ca}$ & 0,012 & 0,007 & 0,001 & 0,004 & 0,005 & 0,008 & 0,027 & 0,002 & 0,003 & 0,012 & 0,007 & 0,005 & 0,000 \\
\hline $\mathrm{Na}$ & 0,216 & 0,223 & 0,238 & 0,257 & 0,112 & 0,254 & 0,084 & 0,216 & 0,235 & 0,204 & 0,169 & 0,241 & 0,141 \\
\hline $\mathrm{K}$ & 1,776 & $\begin{array}{ll}1,811 \\
\end{array}$ & 1,821 & 1,745 & 1,913 & 1,803 & 1,775 & 1,781 & 1,748 & 1,803 & 1,849 & 1,775 & 1,913 \\
\hline $\mathrm{Sr}$ & 0,004 & 0,000 & 0,003 & 0,005 & 0,000 & 0,002 & 0,002 & 0,010 & 0,000 & 0,000 & 0,002 & 0,006 & 0,000 \\
\hline $\mathrm{Ba}$ & 0,005 & 0,000 & 0,000 & 0,003 & 0,000 & 0,004 & 0,012 & 0,000 & 0,000 & 0,002 & 0,000 & 0,002 & 0,000 \\
\hline Sitio I & 2,013 & 2,042 & 2,064 & 2,014 & 2,030 & 2,070 & 1,899 & 2,009 & 1,988 & 2,021 & 2,026 & 2,029 & 2,054 \\
\hline $\mathrm{OH}^{*}$ & 3,975 & 3,997 & 3,989 & 3,982 & 4,000 & 3,967 & 3,858 & 3,945 & 3,926 & 3,966 & 3,996 & 3,949 & 3,989 \\
\hline $\mathrm{F}$ & 0,024 & 0,000 & 0,011 & 0,018 & 0,000 & 0,032 & 0,138 & 0,055 & 0,072 & 0,034 & 0,000 & 0,051 & 0,010 \\
\hline $\mathrm{Cl}$ & 0,001 & 0,003 & 0,000 & 0,000 & 0,000 & 0,001 & 0,003 & 0,000 & 0,003 & 0,000 & 0,004 & 0,000 & 0,001 \\
\hline Sitio A & 4,000 & 4,000 & 4,000 & 4,000 & 4,000 & 4,000 & 4,000 & 4,000 & 4,000 & 4,000 & 4,000 & 4,000 & 4,000 \\
\hline TOTAL & 31,774 & 31,819 & 31,876 & 31,818 & 31,757 & 31,871 & 31,470 & 31,756 & 31,749 & 31,786 & 31,795 & 31,806 & 31,809 \\
\hline
\end{tabular}




\begin{tabular}{|c|c|c|c|c|c|c|c|c|c|c|c|c|c|c|c|c|}
\hline \multicolumn{17}{|c|}{ BIOTITA-MUSCOVITA TONALITO } \\
\hline AMOSTRA & $\begin{array}{c}\text { FPS-4-7- } \\
26,35\end{array}$ & $\begin{array}{c}\text { FPS-4-7- } \\
26,35\end{array}$ & $\begin{array}{c}\text { FPS-4-7- } \\
26,35\end{array}$ & $\begin{array}{c}\text { FPS-4-7- } \\
26,35\end{array}$ & $\begin{array}{c}\text { FPS-5-7- } \\
28,05\end{array}$ & $\begin{array}{c}\text { FPS-5-7- } \\
28,05\end{array}$ & $\begin{array}{c}\text { FPS-5-7- } \\
28,05\end{array}$ & $\begin{array}{c}\text { FPS-5-7- } \\
28,05\end{array}$ & $\begin{array}{c}\text { FPS-5-7- } \\
28,05\end{array}$ & $\begin{array}{c}\text { FPS-1-9- } \\
35,44\end{array}$ & $\begin{array}{c}\text { FPS-1-9- } \\
35,44\end{array}$ & $\begin{array}{c}\text { FPS-1-9- } \\
35,44\end{array}$ & $\begin{array}{c}\text { FPS-1-9- } \\
35,44\end{array}$ & $\begin{array}{c}\text { FPS-1-9- } \\
35,44\end{array}$ & $\begin{array}{c}\text { FPS-7-5- } \\
19,45\end{array}$ & $\begin{array}{c}\text { FPS-7-5- } \\
19,45\end{array}$ \\
\hline ANÁLISE & 1 & 2 & 3 & 4 & 1 & 2 & 3 & 4 & 5 & 1 & 2 & 3 & 4 & 5 & 1 & 2 \\
\hline $\mathrm{SiO} 2$ & 48,766 & 48,835 & 49,503 & 49,395 & 46,119 & 47,369 & 45,432 & 46,026 & 45,654 & 47,064 & 45,993 & 46,095 & 48,077 & 46,277 & 46,67 & 47,359 \\
\hline $\mathrm{TiO} 2$ & 0,151 & 0,196 & 0,045 & 0,097 & 0,014 & 0,042 & 0 & 0 & 0,028 & 0,212 & 0,337 & 0 & 0,147 & 0,329 & 1,153 & 0,283 \\
\hline $\mathrm{Al} 2 \mathrm{O} 3$ & 33,601 & 33,426 & 32,876 & 32,585 & 38,196 & 35,149 & 38,749 & 38,511 & 38,751 & 38,166 & 37,534 & 38,313 & 35,427 & 37,888 & 35,669 & 34,666 \\
\hline $\mathrm{FeO}$ & 2,495 & 2,786 & 3,469 & 3,689 & 0,924 & 1,672 & 0,624 & 0,933 & 0,541 & 1,039 & 1,228 & 1,165 & 1,398 & 1,117 & 1,353 & 1,845 \\
\hline $\mathrm{MnO}$ & 1,185 & 1,213 & 1,253 & 1,279 & 0,056 & 0,04 & 0 & 0,011 & 0,006 & 0,009 & 0,058 & 0,015 & 0,021 & 0 & 0,081 & 0,122 \\
\hline $\mathrm{MgO}$ & 0,054 & 0,048 & 0,124 & 0,07 & 0,402 & 0,919 & 0,159 & 0,253 & 0,166 & 0,535 & 0,583 & 0,638 & 1,079 & 0,661 & 0,698 & 1,06 \\
\hline $\mathrm{CaO}$ & 0,044 & 0,083 & 0 & 0,091 & 0 & 0,02 & 0 & 0,009 & 0 & 0 & 0 & 0,004 & 0,047 & 0,054 & 0,004 & 0,002 \\
\hline $\mathrm{Na} 2 \mathrm{O}$ & 0,268 & 0,267 & 0,226 & 0,198 & 0,655 & 0,344 & 0,71 & 0,602 & 0,692 & 0,698 & 0,6 & 0,637 & 0,441 & 0,584 & 0,356 & 0,298 \\
\hline $\mathrm{K} 2 \mathrm{O}$ & 10,671 & 10,97 & 11,249 & 10,587 & 10,699 & 10,64 & 10,157 & 10,681 & 10,366 & 10,353 & 10,56 & 10,527 & 10,112 & 10,379 & 10,942 & 10,6 \\
\hline $\mathrm{SrO}$ & 0 & 0,022 & 0,039 & 0 & 0,046 & 0 & 0,037 & 0,036 & 0,014 & 0,085 & 0,067 & 0 & 0,052 & 0,019 & 0,053 & 0,046 \\
\hline $\mathrm{BaO}$ & 0,062 & 0,166 & 0,062 & 0,062 & 0,494 & 0,148 & 0,443 & 0,576 & 0,749 & 0,638 & 0,492 & 0,629 & 0,306 & 0,409 & 0,063 & 0 \\
\hline $\mathrm{Cr} 2 \mathrm{O} 3$ & 0 & 0 & 0,008 & 0,009 & 0 & 0 & 0 & 0 & 0 & 0,02 & 0 & 0 & 0 & 0 & 0 & 0 \\
\hline $\mathrm{F}$ & 0,378 & 0,442 & 0,512 & 0,401 & 0,001 & 0,114 & 0 & 0 & 0 & 0 & 0 & 0 & 0 & 0,014 & 0,17 & 0,32 \\
\hline $\mathrm{Cl}$ & 0,006 & 0 & 0,001 & 0,004 & 0 & 0 & 0,008 & 0,001 & 0,009 & 0,026 & 0,013 & 0,017 & 0,008 & 0 & 0,004 & 0,002 \\
\hline $\mathrm{H}_{2} \mathrm{O}^{*}$ & 4,38 & 4,37 & 4,36 & 4,39 & 4,60 & 4,50 & 4,56 & 4,61 & 4,58 & 4,66 & 4,59 & 4,61 & 4,60 & 4,61 & 4,49 & 4,39 \\
\hline Total & 101,90 & 102,74 & 103,51 & 102,79 & 102,22 & 101,08 & 100,92 & 102,27 & 101,57 & 103,57 & 102,09 & 102,65 & 101,71 & 102,33 & 101,63 & 100,86 \\
\hline \multicolumn{17}{|c|}{ FÓRMULA CALCULADA COM BASE EM 22 OXIGÊNIOS } \\
\hline $\mathrm{Si}$ & 6,406 & 6,395 & 6,452 & 6,469 & 6,007 & 6,237 & 5,966 & 5,992 & 5,973 & 6,046 & 6,009 & 5,985 & 6,263 & 6,011 & 6,120 & 6,249 \\
\hline $\mathrm{Al}$ iv & 1,594 & 1,605 & 1,548 & 1,531 & 1,993 & 1,763 & 2,034 & 2,008 & 2,027 & 1,954 & 1,991 & 2,015 & 1,737 & 1,989 & 1,880 & 1,751 \\
\hline Sitio T & 8,000 & 8,000 & 8,000 & 8,000 & 8,000 & 8,000 & 8,000 & 8,000 & 8,000 & 8,000 & 8,000 & 8,000 & 8,000 & 8,000 & 8,000 & 8,000 \\
\hline Al vi & 3,609 & 3,555 & 3,502 & 3,499 & 3,872 & 3,692 & 3,964 & 3,902 & 3,948 & 3,825 & 3,790 & 3,848 & 3,702 & 3,812 & 3,634 & 3,640 \\
\hline $\mathrm{Ti}$ & 0,015 & 0,019 & 0,004 & 0,010 & 0,001 & 0,004 & 0,000 & 0,000 & 0,003 & 0,020 & 0,033 & 0,000 & 0,014 & 0,032 & 0,114 & 0,028 \\
\hline $\mathrm{Cr}$ & 0,000 & 0,000 & 0,001 & 0,001 & 0,000 & 0,000 & 0,000 & 0,000 & 0,000 & 0,002 & 0,000 & 0,000 & 0,000 & 0,000 & 0,000 & 0,000 \\
\hline $\mathrm{Fe}$ & 0,274 & 0,305 & 0,378 & 0,404 & 0,101 & 0,184 & 0,069 & 0,102 & 0,059 & 0,112 & 0,134 & 0,126 & 0,152 & 0,121 & 0,148 & 0,204 \\
\hline $\mathrm{Mn}$ & 0,132 & 0,135 & 0,138 & 0,142 & 0,006 & 0,004 & 0,000 & 0,001 & 0,001 & 0,001 & 0,006 & 0,002 & 0,002 & 0,000 & 0,009 & 0,014 \\
\hline $\mathrm{Mg}$ & 0,011 & 0,009 & 0,024 & 0,014 & 0,078 & 0,180 & 0,031 & 0,049 & 0,032 & 0,102 & 0,114 & 0,123 & 0,210 & 0,128 & 0,136 & 0,208 \\
\hline Sitio M & 4,040 & 4,034 & 4,048 & 4,081 & 4,059 & 4,084 & 4,068 & 4,057 & 4,045 & 4,069 & 4,081 & 4,099 & 4,081 & 4,093 & 4,041 & 4,094 \\
\hline $\mathrm{Ca}$ & 0,006 & 0,012 & 0,000 & 0,013 & 0,000 & 0,003 & 0,000 & 0,001 & 0,000 & 0,000 & 0,000 & 0,001 & 0,007 & 0,008 & 0,001 & 0,000 \\
\hline $\mathrm{Na}$ & 0,068 & 0,068 & 0,057 & 0,050 & 0,165 & 0,088 & 0,181 & 0,152 & 0,176 & 0,174 & 0,152 & 0,160 & 0,111 & 0,147 & 0,091 & 0,076 \\
\hline $\mathrm{K}$ & 1,788 & 1,832 & 1,870 & 1,769 & 1,778 & 1,787 & 1,701 & 1,774 & 1,730 & 1,696 & 1,760 & 1,743 & 1,680 & 1,720 & 1,830 & 1,784 \\
\hline $\mathrm{Sr}$ & 0,000 & 0,002 & 0,003 & 0,000 & 0,003 & 0,000 & 0,003 & 0,003 & 0,001 & 0,006 & 0,005 & 0,000 & 0,004 & 0,001 & 0,004 & 0,004 \\
\hline $\mathrm{Ba}$ & 0,003 & 0,009 & 0,003 & 0,003 & 0,025 & 0,008 & 0,023 & 0,029 & 0,038 & 0,032 & 0,025 & 0,032 & 0,016 & 0,021 & 0,003 & 0,000 \\
\hline Sitio I & 1,866 & 1,922 & 1,933 & 1,835 & 1,972 & 1,885 & 1,908 & 1,959 & 1,945 & 1,909 & 1,942 & 1,936 & 1,818 & 1,896 & 1,929 & 1,864 \\
\hline $\mathrm{OH}^{*}$ & 3,842 & 3,817 & 3,789 & 3,833 & 4,000 & 3,953 & 3,998 & 4,000 & 3,998 & 3,994 & 3,997 & 3,996 & 3,998 & 3,994 & 3,929 & 3,866 \\
\hline$F$ & 0,157 & 0,183 & 0,211 & 0,166 & 0,000 & 0,047 & 0,000 & 0,000 & 0,000 & 0,000 & 0,000 & 0,000 & 0,000 & 0,006 & 0,071 & 0,134 \\
\hline $\mathrm{Cl}$ & 0,001 & 0,000 & 0,000 & 0,001 & 0,000 & 0,000 & 0,002 & 0,000 & 0,002 & 0,006 & 0,003 & 0,004 & 0,002 & 0,000 & 0,001 & 0,000 \\
\hline Sitio A & 4,000 & 4,000 & 4,000 & 4,000 & 4,000 & 4,000 & 4,000 & 4,000 & 4,000 & 4,000 & 4,000 & 4,000 & 4,000 & 4,000 & 4,000 & 4,000 \\
\hline TOTAL & 31,812 & 31,911 & 31,963 & 31,831 & 32,061 & 31,937 & 31,952 & 32,031 & 31,979 & 31,956 & 32,046 & 32,071 & 31,797 & 31,980 & 31,940 & 31,915 \\
\hline
\end{tabular}


ANEXO 03

QUÍMICA MINERAL

DA BIOTITA 


\begin{tabular}{|c|c|c|c|c|c|c|c|c|c|c|c|c|c|}
\hline \multicolumn{14}{|c|}{ MUSCOVITA-BIOTITA TONALITO } \\
\hline AMOSTRA & $\begin{array}{c}\text { FPS-8-8- } \\
33,88\end{array}$ & $\begin{array}{c}\text { FPS-8-8- } \\
33,88\end{array}$ & $\begin{array}{c}\text { FPS-8-8- } \\
33,88\end{array}$ & $\begin{array}{c}\text { FPS-8-8- } \\
33,88\end{array}$ & $\begin{array}{c}\text { FPS-8-8- } \\
33,88\end{array}$ & $\begin{array}{c}\text { FPS-8-8- } \\
33,88\end{array}$ & $\begin{array}{c}\text { FPS-8-8- } \\
33,88\end{array}$ & $\begin{array}{c}\text { FPS-8-8- } \\
33,88\end{array}$ & $\begin{array}{c}\text { FPS-8-8- } \\
33,88\end{array}$ & $\begin{array}{c}\text { FPS-8-8- } \\
33,88\end{array}$ & $\begin{array}{c}\text { FPS-8-8- } \\
33,88\end{array}$ & $\begin{array}{c}\text { FPS-8-8- } \\
33,88\end{array}$ & $\begin{array}{c}\text { FPS-8-8 } \\
33,88\end{array}$ \\
\hline ANÁLISE & $1 . \mathrm{n}$ & 1.b & $2 . n$ & $3 . n$ & $4 . n$ & 4.b & $5 . n$ & $5 . \mathrm{b}$ & 6.b & 7.b & $7 . n$ & $8 . \mathrm{b}$ & $10 . \mathrm{n}$ \\
\hline $\mathrm{SiO} 2$ & 35,662 & 38,639 & 36,042 & 35,78 & 33,743 & 34,543 & 36,012 & 36,225 & 34,407 & 34,835 & 35,158 & 35,728 & 36,114 \\
\hline $\mathrm{TiO} 2$ & 1,273 & 0,973 & 1,097 & 1,256 & 5,837 & 1,459 & 1,184 & 0,953 & 0,825 & 1,424 & 1,535 & 1,501 & 0,889 \\
\hline $\mathrm{Al} 2 \mathrm{O} 3$ & 17,798 & 21,556 & 17,651 & 17,874 & 15,954 & 17,517 & 17,494 & 17,789 & 17,453 & 17,106 & 17,47 & 17,546 & 17,98 \\
\hline $\mathrm{FeO}$ & 24,134 & 17,695 & 23,039 & 23,113 & 21,458 & 24,319 & 24,598 & 24,174 & 24,833 & 23,611 & 23,423 & 23,765 & 23,948 \\
\hline $\mathrm{MnO}$ & 0,328 & 0,163 & 0,294 & 0,301 & 0,148 & 0,243 & 0,306 & 0,245 & 0,285 & 0,157 & 0,28 & 0,264 & 0,209 \\
\hline $\mathrm{MgO}$ & 7,52 & 5,718 & 7,476 & 7,611 & 6,932 & 8,098 & 7,474 & 7,727 & 7,31 & 7,694 & 7,291 & 7,446 & 7,473 \\
\hline $\mathrm{CaO}$ & 0,029 & 0,021 & 0,02 & 0 & 3,892 & 0,002 & 0,038 & 0,042 & 0,022 & 0,054 & 0 & 0,028 & 0,019 \\
\hline $\mathrm{Na} 2 \mathrm{O}$ & 0 & 0,042 & 0,053 & 0,022 & 0,024 & 0,017 & 0,086 & 0,03 & 0,029 & 0,067 & 0,014 & 0,018 & 0,128 \\
\hline $\mathrm{K} 2 \mathrm{O}$ & 9,612 & 9,928 & 9,646 & 9,467 & 7,649 & 9,015 & 9,564 & 9,773 & 9,27 & 9,371 & 9,643 & 9,503 & 9,548 \\
\hline $\mathrm{SrO}$ & 0 & 0 & 0,029 & 0,045 & 0 & 0 & 0 & 0 & 0 & 0 & 0 & 0,019 & 0 \\
\hline $\mathrm{BaO}$ & 0,093 & 0 & 0,255 & 0,094 & 0,035 & 0,024 & 0 & 0 & 0 & 0,117 & 0,036 & 0,162 & 0,15 \\
\hline $\mathrm{V} 2 \mathrm{O} 3$ & 0,066 & 0,044 & 0,058 & 0 & 0 & 0,029 & 0,045 & 0,055 & 0,074 & 0 & 0 & 0,013 & 0 \\
\hline $\mathrm{F}$ & 0,554 & 0,519 & 0,62 & 0,704 & 0,775 & 0,582 & 0,563 & 0,752 & 0,595 & 0,737 & 0,579 & 0,602 & 0,714 \\
\hline $\mathrm{Cl}$ & 0,023 & 0,049 & 0,034 & 0,036 & 0,008 & 0,018 & 0,01 & 0,058 & 0,034 & 0,06 & 0,043 & 0,01 & 0,061 \\
\hline Li2O* & 0,68 & 1,54 & 0,79 & 0,72 & 0,13 & 0,36 & 0,78 & 0,84 & 0,32 & 0,45 & 0,54 & 0,70 & 0,81 \\
\hline $\mathrm{H}_{2} \mathrm{O}^{*}$ & 3,66 & 3,82 & 3,61 & 3,57 & 3,51 & 3,57 & 3,67 & 3,59 & 3,51 & 3,46 & 3,57 & 3,62 & 3,59 \\
\hline Total & 101,19 & 100,48 & 100,45 & 100,28 & 99,77 & 99,55 & 101,59 & 101,93 & 98,71 & 98,82 & 99,33 & 100,68 & 101,32 \\
\hline \multicolumn{14}{|c|}{ FORMULA CALCULADA COM BASE EM 22 OXIGÊNIOS } \\
\hline $\mathrm{Si}$ & 5,450 & 5,674 & 5,524 & 5,484 & 5,219 & 5,375 & 5,482 & 5,485 & 5,428 & 5,457 & 5,468 & 5,476 & 5,493 \\
\hline $\mathrm{Al}$ iv & 2,550 & 2,326 & 2,476 & 2,516 & 2,781 & 2,625 & 2,518 & 2,515 & 2,572 & 2,543 & 2,532 & 2,524 & 2,507 \\
\hline Sitio T & 8,000 & 8,000 & 8,000 & 8,000 & 8,000 & $\frac{2,0200}{8,000}$ & 8,000 & 8,000 & 8,000 & 8,000 & 8,000 & 8,000 & 8,000 \\
\hline $\mathrm{Al}$ vi & 0,656 & 1,405 & 0,712 & 0,713 & 0,128 & 0,588 & 0,621 & 0,660 & 0,674 & 0,615 & 0,670 & 0,646 & 0,717 \\
\hline $\mathrm{Ti}$ & 0,146 & 0,107 & 0,126 & 0,145 & 0,679 & 0,171 & 0,136 & 0,109 & 0,098 & 0,168 & 0,180 & 0,173 & 0,102 \\
\hline $\mathrm{Cr}$ & 0,000 & 0,000 & 0,000 & 0,000 & 0,000 & 0,000 & 0,000 & 0,000 & 0,000 & 0,000 & 0,000 & 0,000 & 0,000 \\
\hline $\mathrm{Fe}$ & 3,084 & 2,173 & 2,953 & 2,963 & 2,776 & 3,165 & 3,132 & 3,061 & 3,277 & 3,093 & 3,046 & 3,046 & 3,047 \\
\hline $\mathrm{Mn}$ & 0,042 & 0,020 & 0,038 & 0,039 & 0,019 & 0,032 & 0,039 & 0,031 & 0,038 & 0,021 & 0,037 & 0,034 & 0,027 \\
\hline $\mathrm{Mg}$ & 1,713 & 1,252 & 1,708 & 1,739 & 1,598 & 1,878 & 1,696 & 1,744 & 1,719 & 1,797 & 1,690 & 1,701 & 1,695 \\
\hline $\mathrm{Li}^{*}$ & 0,420 & 0,908 & 0,488 & 0,442 & $\begin{array}{l}0,082 \\
\end{array}$ & 0,226 & $\begin{array}{l}0,480 \\
\end{array}$ & 0,514 & 0,205 & 0,281 & $\begin{array}{l}0,337 \\
\end{array}$ & 0,433 & 0,497 \\
\hline SitioM & 6,062 & 5,866 & 6,026 & 6,040 & 5,283 & 6,061 & 6,104 & 6,119 & 6,010 & 5,974 & 5,959 & 6,034 & 6,084 \\
\hline $\mathrm{Ca}$ & 0,005 & 0,003 & 0,003 & 0,000 & 0,645 & 0,000 & 0,006 & 0,007 & 0,004 & 0,009 & 0,000 & 0,005 & 0,003 \\
\hline $\mathrm{Na}$ & 0,000 & $\begin{array}{l}0,012 \\
0,012\end{array}$ & 0,016 & 0,007 & 0,007 & 0,005 & 0,025 & $\begin{array}{l}0,009 \\
\end{array}$ & 0,009 & 0,020 & 0,004 & 0,005 & 0,038 \\
\hline $\mathrm{K}$ & 1,874 & 1,860 & 1,886 & 1,851 & 1,509 & 1,789 & 1,857 & 1,887 & 1,865 & 1,872 & 1,913 & 1,858 & 1,853 \\
\hline $\mathrm{Sr}$ & 0,000 & 0,000 & 0,003 & 0,004 & 0,000 & 0,000 & 0,000 & 0,000 & 0,000 & 0,000 & 0,000 & 0,002 & 0,000 \\
\hline $\mathrm{Ba}$ & 0,006 & 0,000 & 0,015 & 0,006 & $\begin{array}{l}0,002 \\
\end{array}$ & 0,001 & 0,000 & 0,000 & 0,000 & 0,007 & 0,002 & 0,010 & 0,009 \\
\hline $\mathrm{V}$ & 0,004 & 0,003 & 0,004 & 0,000 & 0,000 & 0,002 & 0,003 & 0,004 & 0,005 & $\begin{array}{l}0,0000 \\
0,000\end{array}$ & $\begin{array}{l}0,0000 \\
0,000\end{array}$ & $\begin{array}{l}, 010 \\
0,433\end{array}$ & $\begin{array}{l}0,009 \\
0,000\end{array}$ \\
\hline Sitio I & 1,888 & 1,878 & 1,926 & 1,867 & 2,164 & 1,798 & 1,892 & 1,907 & 1,883 & 1,909 & 1,919 & 0,001 & 1,902 \\
\hline $\mathrm{OH}^{*}$ & 3,726 & 3,747 & 3,691 & 3,649 & 3,619 & 3,709 & 3,726 & 3,625 & 3,694 & 3,619 & 3,704 & 1,880 & 3,641 \\
\hline $\mathrm{F}$ & 0,268 & 0,241 & 0,301 & 0,341 & 0,379 & 0,286 & 0,271 & 0,360 & 0,297 & 0,365 & 0,285 & 3,706 & 0,343 \\
\hline $\mathrm{Cl}$ & 0,006 & 0,012 & 0,009 & 0,009 & 0,002 & 0,005 & 0,003 & 0,015 & 0,009 & 0,016 & 0,011 & 0,292 & 0,016 \\
\hline Sitio A & 4,000 & 4,000 & 4,000 & 4,000 & 4,000 & 4,000 & 4,000 & 4,000 & 4,000 & 4,000 & 4,000 & 0,003 & 4,000 \\
\hline TOTAL & 35,900 & 35,488 & 35,905 & 35,813 & 34,893 & 35,718 & 35,991 & 36,052 & 35,786 & 35,766 & 35,757 & 4,000 & 35,973 \\
\hline
\end{tabular}




\begin{tabular}{|c|c|c|c|c|c|c|c|c|c|c|c|c|}
\hline \multicolumn{11}{|c|}{ MUSCOVITA-BIOTITA TONALITO } & \multicolumn{2}{|c|}{$\begin{array}{c}\text { MUSCOVITA-BIOTITA } \\
\text { MONZOGRANITO }\end{array}$} \\
\hline AMOSTRA & FPS-8-8-33,88 & FPS-8-8-33,88 & FPS-8-8-33,88 & FPS-8-8-33,88 & FPS-8-7-31,06 & FPS-8-7-31,06 & FPS-8-7-31,06 & FPS-8-7-31,06 & FPS-8-7-31,06 & $\begin{array}{c}\text { FPS-8-7- } \\
31,06\end{array}$ & FPS-8-6-27,45 & FPS-8-6-27,45 \\
\hline ANÁLISE & $11 . n$ & $11 . \mathrm{b}$ & 13.n & $14 . n$ & 1.n & $4 . n$ & $5 . \mathrm{n}$ & $6 . \mathrm{n}$ & $7 . \mathrm{n}$ & $7 . \mathrm{b}$ & $1 . \mathrm{b}$ & 1.n \\
\hline $\mathrm{SiO} 2$ & 34,323 & 35,93 & 35,628 & 35,105 & 34,725 & 34,679 & 36,282 & 35,909 & 35,607 & 36,872 & 35,842 & 36,047 \\
\hline $\mathrm{TiO} 2$ & 1,324 & 1,134 & 1,102 & 0,998 & 0,936 & 0,96 & 1,044 & 0,952 & $\begin{array}{ll}1,199 \\
\end{array}$ & 1,136 & 1,414 & 0,96 \\
\hline $\mathrm{Al} 2 \mathrm{O} 3$ & 17,182 & 18,071 & 17,427 & 17,488 & 18,169 & 17,364 & 17,816 & 17,85 & 17,471 & 17,498 & 17,913 & 17,759 \\
\hline $\mathrm{FeO}$ & 25,39 & 24,698 & 23,319 & 24,902 & 24,304 & 23,7 & 22,707 & 23,095 & 23,451 & 22,487 & 22,918 & 22,512 \\
\hline $\mathrm{MnO}$ & 0,239 & 0,327 & 0,27 & 0,327 & 0,204 & 0,156 & 0,118 & 0,191 & 0,097 & 0,192 & 0,145 & 0,249 \\
\hline $\mathrm{MgO}$ & 7,654 & 7,616 & 7,656 & 7,881 & 9,501 & 8,753 & 8,314 & 8,115 & 8,114 & 8,446 & 8,077 & 8,075 \\
\hline $\mathrm{CaO}$ & 0,026 & 0,03 & 0 & 0,08 & 0,072 & 0 & 0 & 0 & 0,07 & 0,055 & 0,3 & 0,045 \\
\hline $\mathrm{Na} 2 \mathrm{O}$ & 0,097 & 0,077 & 0,066 & 0 & 0,077 & 0 & 0,072 & 0,011 & 0,082 & 0,072 & 0,043 & 0,214 \\
\hline $\mathrm{K} 2 \mathrm{O}$ & 8,789 & 9,199 & 9,59 & 8,643 & 7,665 & 8,993 & 9,749 & 9,799 & 9,558 & 9,59 & 9,283 & 9,474 \\
\hline $\mathrm{SrO}$ & 0,031 & 0 & 0,005 & 0,052 & 0 & 0 & 0,104 & 0,079 & 0 & 0,076 & 0,016 & 0 \\
\hline $\mathrm{BaO}$ & 0 & 0,115 & 0,104 & 0,081 & 0,033 & 0 & 0,046 & 0,114 & 0 & 0,001 & 0,012 & 0 \\
\hline $\mathrm{V} 2 \mathrm{O} 3$ & 0,055 & 0,045 & 0,013 & 0 & 0 & 0,017 & 0,018 & 0,071 & 0,054 & 0,013 & 0,03 & 0,095 \\
\hline $\mathrm{F}$ & 0,569 & 0,625 & 0,64 & 0,59 & 0,199 & 0,233 & 0,275 & 0,224 & 0,268 & 0,255 & 0,296 & 0,286 \\
\hline $\mathrm{Cl}$ & 0,015 & 0,044 & 0,029 & 0,055 & 0,028 & 0,053 & 0,028 & 0,056 & 0,03 & 0,029 & 0,025 & 0,035 \\
\hline Li2O* & 0,30 & 0,76 & 0,67 & 0,52 & 0,41 & 0,40 & 0,86 & 0,75 & 0,67 & 1,03 & 0,73 & 0,79 \\
\hline $\mathrm{H}_{2} \mathrm{O}^{*}$ & 3,55 & 3,65 & 3,57 & 3,58 & 3,81 & 3,72 & 3,82 & 3,81 & 3,77 & 3,86 & 3,79 & 3,78 \\
\hline Total & 99,30 & 102,05 & 99,82 & 100,05 & 100,05 & 98,92 & 101,13 & 100,92 & 100,32 & 101,50 & 100,71 & 100,19 \\
\hline \multicolumn{13}{|c|}{ FORMULA CALCULADA COM BASE EM 22 OXIGÊNIOS } \\
\hline $\mathrm{Si}$ & 5,385 & 5,438 & 5,502 & 5,431 & 5,323 & 5,409 & 5,497 & 5,476 & 5,466 & 5,544 & 5,453 & 5,510 \\
\hline $\mathrm{Al}$ iv & 2,615 & 2,562 & 2,498 & 2,569 & 2,677 & 2,591 & 2,503 & 2,524 & 2,534 & 2,456 & 2,547 & 2,490 \\
\hline Sitio T & 8,000 & 8,000 & 8,000 & 8,000 & 8,000 & 8,000 & 8,000 & 8,000 & 8,000 & 8,000 & 8,000 & 8,000 \\
\hline $\mathrm{Al}$ vi & 0,563 & 0,662 & 0,675 & 0,621 & 0,605 & 0,601 & 0,678 & 0,685 & 0,628 & 0,645 & 0,666 & 0,710 \\
\hline $\mathrm{Ti}$ & 0,156 & 0,129 & 0,128 & 0,116 & 0,108 & 0,113 & 0,119 & 0,109 & 0,138 & 0,128 & 0,162 & 0,110 \\
\hline $\mathrm{Cr}$ & 0,000 & 0,000 & 0,000 & 0,000 & 0,000 & 0,000 & 0,000 & 0,000 & 0,000 & 0,000 & 0,000 & 0,000 \\
\hline $\mathrm{Fe}$ & 3,332 & 3,126 & 3,012 & 3,222 & 3,116 & 3,092 & 2,877 & 2,945 & 3,011 & 2,828 & 2,916 & 2,878 \\
\hline $\mathrm{Mn}$ & 0,032 & 0,042 & 0,035 & 0,043 & 0,026 & 0,021 & 0,015 & 0,025 & 0,013 & 0,024 & 0,019 & 0,032 \\
\hline $\mathrm{Mg}$ & 1,790 & 1,718 & 1,763 & 1,818 & 2,171 & 2,035 & 1,878 & 1,845 & 1,857 & 1,893 & 1,832 & 1,840 \\
\hline $\mathrm{Li}^{*}$ & 0,188 & 0,463 & 0,418 & 0,326 & 0,255 & 0,251 & 0,525 & 0,462 & 0,412 & 0,623 & 0,450 & 0,488 \\
\hline SitioM & 6,061 & 6,140 & 6,031 & 6,145 & 6,281 & 6,113 & 6,091 & 6,071 & 6,059 & 6,142 & 6,044 & 6,058 \\
\hline $\mathrm{Ca}$ & 0,004 & 0,005 & 0,000 & 0,013 & 0,012 & 0,000 & 0,000 & 0,000 & 0,012 & 0,009 & 0,049 & 0,007 \\
\hline $\mathrm{Na}$ & 0,030 & 0,023 & 0,020 & 0,000 & 0,023 & 0,000 & 0,021 & 0,003 & 0,024 & 0,021 & 0,013 & 0,063 \\
\hline $\mathrm{K}$ & 1,759 & 1,776 & 1,889 & 1,706 & 1,499 & 1,789 & 1,884 & 1,906 & 1,872 & 1,839 & 1,802 & 1,847 \\
\hline $\mathrm{Sr}$ & 0,003 & 0,000 & 0,000 & 0,005 & 0,000 & 0,000 & 0,009 & 0,007 & 0,000 & 0,007 & 0,001 & 0,000 \\
\hline $\mathrm{Ba}$ & 0,000 & 0,007 & 0,006 & 0,005 & 0,002 & 0,000 & 0,003 & 0,007 & 0,000 & 0,000 & 0,001 & 0,000 \\
\hline $\mathrm{V}$ & 0,004 & 0,003 & 0,001 & 0,000 & 0,000 & 0,001 & 0,001 & 0,005 & 0,004 & 0,001 & 0,002 & 0,006 \\
\hline Sitio I & 1,799 & 1,813 & 1,917 & 1,729 & 1,535 & 1,790 & 1,918 & 1,928 & 1,911 & 1,877 & 1,867 & 1,924 \\
\hline $\mathrm{OH}^{*}$ & 3,714 & 3,690 & 3,680 & 3,697 & 3,896 & 3,871 & 3,861 & 3,877 & 3,862 & 3,871 & 3,851 & 3,853 \\
\hline $\mathrm{F}$ & 0,282 & 0,299 & 0,313 & 0,289 & 0,096 & 0,115 & 0,132 & 0,108 & 0,130 & 0,121 & 0,142 & 0,138 \\
\hline $\mathrm{Cl}$ & 0,004 & 0,011 & 0,008 & 0,014 & 0,007 & 0,014 & 0,007 & 0,014 & 0,008 & 0,007 & 0,006 & 0,009 \\
\hline Sitio A & 4,000 & 4,000 & 4,000 & 4,000 & 4,000 & 4,000 & 4,000 & 4,000 & 4,000 & 4,000 & 4,000 & 4,000 \\
\hline TOTAL & 35,720 & 35,906 & 35,895 & 35,747 & 35,633 & 35,806 & 36,018 & 35,997 & 35,940 & 36,038 & 35,823 & 35,964 \\
\hline
\end{tabular}




\begin{tabular}{|c|c|c|c|c|c|c|c|c|c|c|c|c|c|c|c|c|}
\hline \multicolumn{17}{|c|}{ MUSCOVITA-BIOTITA MONZOGRANITO } \\
\hline AMOSTRA & $\begin{array}{c}\text { FPS-8-6- } \\
27,45 \\
\end{array}$ & $\begin{array}{c}\text { FPS-8-6- } \\
27,45 \\
\end{array}$ & $\begin{array}{c}\text { FPS-8-6- } \\
27,45 \\
\end{array}$ & $\begin{array}{c}\text { FPS-8-6- } \\
27,45\end{array}$ & $\begin{array}{c}\text { FPS-8-6- } \\
27,45\end{array}$ & $\begin{array}{c}\text { FPS-8-6- } \\
27,45\end{array}$ & $\begin{array}{c}\text { FPS-8-6- } \\
27,45\end{array}$ & $\begin{array}{c}\text { FPS-8-6- } \\
27,45\end{array}$ & $\begin{array}{c}\text { FPS-7-7- } \\
30,70\end{array}$ & $\begin{array}{c}\text { FPS-7-7- } \\
30,70\end{array}$ & $\begin{array}{c}\text { FPS-7-7- } \\
30,70\end{array}$ & $\begin{array}{c}\text { FPS-7-7- } \\
30,70\end{array}$ & $\begin{array}{c}\text { FPS-7-7- } \\
30,70\end{array}$ & $\begin{array}{c}\text { FPS-7-7- } \\
30,70\end{array}$ & $\begin{array}{c}\text { FPS-7-7- } \\
30,70\end{array}$ & $\begin{array}{c}\text { FPS-7-7- } \\
30,70\end{array}$ \\
\hline ANÁLISE & $2 . \mathrm{n}$ & $3 . \mathrm{n}$ & 3.b & $4 . n$ & $5 . \mathrm{n}$ & $5 . \mathrm{b}$ & $6 . \mathrm{n}$ & 6.b & 1.b & 1.n & $2 . \mathrm{n}$ & $3 . \mathrm{n}$ & 3.b & $4 . n$ & 4.b & $5 . \mathrm{n}$ \\
\hline $\mathrm{SiO2}$ & 34,845 & 35,453 & 35,842 & 36,047 & 36,054 & 35,353 & 35,176 & 36,07 & 34,917 & 40,009 & 35,754 & 34,613 & 34,021 & 34,974 & 34,533 & 33,108 \\
\hline $\mathrm{TiO} 2$ & 0,913 & 1,683 & 1,414 & 0,96 & 1,453 & 1,344 & 1,301 & 1,18 & 1,783 & 0,916 & 0,883 & 1,623 & 1,267 & 1,484 & 1,715 & 1,329 \\
\hline $\mathrm{Al} 2 \mathrm{O} 3$ & 17,607 & 17,824 & 17,913 & 17,759 & 17,756 & 17,643 & 17,514 & 17,896 & 18,943 & 22,519 & 19,077 & 18,317 & 18,454 & 18,808 & 18,545 & 19,316 \\
\hline $\mathrm{FeO}$ & 24,121 & 22,901 & 22,918 & 22,512 & 23,291 & 23,707 & 23,237 & 23,326 & 25,202 & 18,036 & 24,278 & 25,25 & 25,237 & 25,636 & 25,157 & 27,018 \\
\hline $\mathrm{MnO}$ & 0,114 & 0,094 & 0,145 & 0,249 & 0,177 & 0,205 & 0,125 & 0,163 & 0,341 & 0,245 & 0,296 & 0,378 & 0,237 & 0,323 & 0,228 & 0,356 \\
\hline $\mathrm{MgO}$ & 8,19 & 7,971 & 8,077 & 8,075 & 8,053 & 8,431 & 8,105 & 8,119 & 5,787 & 4,925 & 6,093 & 6,17 & 6,257 & 6,461 & 6,644 & 7,424 \\
\hline $\mathrm{CaO}$ & 0,022 & 0,223 & 0,3 & 0,045 & 0,017 & 0,048 & 0,035 & 0,021 & 0,083 & 0,068 & 0,098 & 0,058 & 0,002 & 0,096 & 0,343 & 0,369 \\
\hline $\mathrm{Na2O}$ & 0 & 0,06 & 0,043 & 0,214 & 0,038 & 0,07 & 0,066 & 0,005 & 0,053 & 0,083 & 0,063 & 0,03 & 0,031 & 0,061 & 0,091 & 0,083 \\
\hline $\mathrm{K} 2 \mathrm{O}$ & 9,504 & 9,71 & 9,283 & 9,474 & 9,76 & 8,955 & 9,64 & 9,403 & 9,232 & 9,628 & 8,762 & 9,564 & 9,43 & 9,232 & 8,949 & 6,336 \\
\hline SrO & 0,054 & 0 & 0,016 & 0 & 0 & 0 & 0 & 0,096 & 0 & 0,057 & 0,033 & 0,091 & 0,009 & 0 & 0 & 0,009 \\
\hline $\mathrm{BaO}$ & 0,023 & 0,103 & 0,012 & 0 & 0,275 & 0,185 & 0,104 & 0,195 & 0,067 & 0,116 & 0,092 & 0,058 & 0,047 & 0 & 0,035 & 0 \\
\hline $\mathrm{V} 2 \mathrm{O} 3$ & 0,012 & 0,053 & 0,03 & 0,095 & 0 & 0,038 & 0,043 & 0,006 & 0,044 & 0,074 & 0,117 & 0,125 & 0,058 & 0,001 & 0,031 & 0,025 \\
\hline $\mathrm{F}$ & 0,322 & 0,155 & 0,296 & 0,286 & 0,202 & 0,133 & 0,311 & 0,285 & 0,171 & 0,221 & 0,199 & 0,235 & 0,242 & 0,318 & 0,35 & 0,213 \\
\hline $\mathrm{Cl}$ & 0,024 & 0,044 & 0,025 & 0,035 & 0,019 & 0,029 & 0,003 & 0,029 & 0,019 & 0,032 & 0,015 & 0,052 & 0,043 & 0,021 & 0,039 & 0,003 \\
\hline $\mathrm{H}_{2} \mathrm{O}^{*}$ & 3,68 & 3,80 & 3,75 & 3,73 & 3,82 & 3,81 & 3,70 & 3,77 & 3,79 & 3,98 & 3,77 & 3,72 & 3,67 & 3,74 & 3,69 & 3,74 \\
\hline Total & 99,29 & 100,00 & 99,94 & 99,36 & 100,82 & 99,89 & 99,23 & 100,44 & 100,35 & 100,81 & 99,45 & 100,17 & 98,89 & 101,01 & 100,19 & 99,24 \\
\hline \multicolumn{17}{|c|}{ FORMULA CALCULADA COM BASE EM 22 OXIGÊNIIOS } \\
\hline $\mathrm{Si}$ & 5,445 & 5,469 & 5,510 & 5,572 & 5,519 & 5,462 & 5,481 & 5,531 & 5,407 & 5,859 & 5,538 & 5,401 & 5,373 & 5,387 & 5,359 & 5,171 \\
\hline $\mathrm{Al}$ iv & 2,555 & 2,531 & 2,490 & 2,428 & 2,481 & 2,538 & 2,519 & 2,469 & 2,593 & 2,141 & 2,462 & 2,599 & 2,627 & 2,613 & 2,641 & 2,829 \\
\hline Sitio $\mathrm{T}$ & 8,000 & 8,000 & 8,000 & 8,000 & 8,000 & 8,000 & 8,000 & 8,000 & 8,000 & 8,000 & 8,000 & 8,000 & 8,000 & 8,000 & 8,000 & 8,000 \\
\hline Al vi & 0,687 & 0,710 & 0,755 & 0,807 & 0,723 & 0,675 & 0,697 & 0,766 & 0,865 & 1,746 & 1,021 & 0,771 & 0,809 & 0,802 & 0,752 & 0,727 \\
\hline $\mathrm{Ti}$ & 0,107 & 0,195 & 0,163 & 0,112 & 0,167 & 0,156 & 0,152 & 0,136 & 0,208 & 0,101 & 0,103 & 0,190 & 0,150 & 0,172 & 0,200 & 0,156 \\
\hline $\mathrm{Cr}$ & 0,000 & 0,000 & 0,000 & 0,000 & 0,000 & 0,000 & 0,000 & 0,000 & 0,000 & 0,000 & 0,000 & 0,000 & 0,000 & 0,000 & 0,000 & 0,000 \\
\hline $\mathrm{Fe}$ & 3,152 & 2,955 & 2,946 & 2,910 & 2,982 & 3,063 & 3,028 & 2,992 & 3,264 & 2,209 & 3,145 & 3,295 & 3,334 & 3,302 & 3,265 & 3,529 \\
\hline $\mathrm{Mn}$ & 0,015 & 0,012 & 0,019 & 0,033 & 0,023 & 0,027 & 0,016 & 0,021 & 0,045 & 0,030 & 0,039 & 0,050 & 0,032 & 0,042 & 0,030 & 0,047 \\
\hline $\mathrm{Mg}$ & 1,908 & 1,833 & 1,851 & 1,861 & 1,838 & 1,942 & 1,883 & 1,856 & 1,336 & 1,075 & 1,407 & 1,435 & 1,473 & 1,484 & 1,537 & 1,728 \\
\hline SitioM & 5,869 & 5,706 & 5,735 & 5,722 & 5,733 & 5,862 & 5,777 & 5,771 & 5,717 & 5,161 & 5,714 & 5,742 & 5,798 & 5,802 & 5,784 & 6,188 \\
\hline $\mathrm{Ca}$ & 0,004 & 0,037 & 0,049 & 0,007 & 0,003 & 0,008 & 0,006 & 0,003 & 0,014 & 0,011 & 0,016 & 0,010 & 0,000 & 0,016 & 0,057 & 0,062 \\
\hline $\mathrm{Na}$ & 0,000 & 0,018 & 0,013 & 0,064 & 0,011 & 0,021 & 0,020 & 0,001 & 0,016 & 0,024 & 0,019 & 0,009 & 0,009 & 0,018 & 0,027 & 0,025 \\
\hline $\mathrm{K}$ & 1,894 & 1,911 & 1,820 & 1,868 & 1,906 & 1,765 & 1,916 & 1,839 & 1,824 & 1,798 & 1,731 & 1,904 & 1,900 & 1,814 & 1,772 & 1,262 \\
\hline Sr & 0,005 & 0,000 & 0,001 & 0,000 & 0,000 & 0,000 & 0,000 & 0,009 & 0,000 & 0,005 & 0,003 & 0,008 & 0,001 & 0,000 & 0,000 & 0,001 \\
\hline $\mathrm{Ba}$ & 0,001 & 0,006 & 0,001 & 0,000 & 0,016 & 0,011 & 0,006 & 0,012 & 0,004 & 0,007 & 0,006 & 0,004 & 0,003 & 0,000 & 0,002 & 0,000 \\
\hline $\mathrm{V}$ & 0,001 & 0,003 & 0,002 & 0,006 & 0,000 & 0,003 & 0,003 & 0,000 & 0,003 & 0,005 & 0,008 & 0,008 & 0,004 & 0,000 & 0,002 & 0,002 \\
\hline Sitio I & 1,905 & 1,975 & 1,887 & 1,946 & 1,936 & 1,807 & 1,951 & 1,865 & 1,860 & 1,849 & 1,783 & 1,943 & 1,917 & 1,848 & 1,860 & 1,352 \\
\hline $\mathrm{OH}^{*}$ & 3,835 & 3,913 & 3,850 & 3,851 & 3,897 & 3,927 & 3,846 & 3,854 & 3,911 & 3,890 & 3,899 & 3,870 & 3,868 & 3,840 & 3,818 & 3,894 \\
\hline $\mathrm{F}$ & 0,159 & 0,076 & 0,144 & 0,140 & 0,098 & 0,065 & 0,153 & 0,138 & 0,084 & 0,102 & 0,097 & 0,116 & 0,121 & 0,155 & 0,172 & 0,105 \\
\hline $\mathrm{Cl}$ & 0,006 & 0,012 & 0,007 & 0,009 & 0,005 & 0,008 & 0,001 & 0,008 & 0,005 & 0,008 & 0,004 & 0,014 & 0,012 & 0,005 & 0,010 & 0,001 \\
\hline Sitio A & 4,000 & 4,000 & 4,000 & 4,000 & 4,000 & 4,000 & 4,000 & 4,000 & 4,000 & 4,000 & 4,000 & 4,000 & 4,000 & 4,000 & 4,000 & 4,000 \\
\hline TOTAL & 35,549 & 35,362 & 35,243 & 35,336 & 35,340 & 35,339 & 35,456 & 35,272 & 35,155 & 34,020 & 34,993 & 35,368 & 35,430 & 35,299 & 35,289 & 35,079 \\
\hline
\end{tabular}




\section{ANEXO 04 \\ QUÍMICA MINERAL \\ DA CASSITERITA}




\begin{tabular}{|c|c|c|c|c|c|c|c|c|c|c|c|c|c|c|c|c|}
\hline \multicolumn{17}{|c|}{ ALBITITO (BOA VISTA) } \\
\hline AMOSTRA & PA-1D & PA-1D & PA-1D & PA-1D & PA-1D & PA-1D & PA-1D & PA-1D & PA-1D & PA-1D & PA-1D & PA-1D & PA-1D & PA-II & PA-II & PA-II \\
\hline ANÁLISE & 1.B & $1 . \mathrm{N}$ & 2.B & $2 . \mathrm{N}$ & MAV.1 & MAV.2 & $\begin{array}{l}\text { MAM.2. } \\
\text { N }\end{array}$ & $\begin{array}{c}\text { MAV.2. } \\
\text { B }\end{array}$ & $\begin{array}{c}\text { MAM.3. } \\
\text { N }\end{array}$ & $\begin{array}{c}\text { MAV.3. } \\
\text { B }\end{array}$ & $\begin{array}{l}\text { MAM.4. } \\
\text { N }\end{array}$ & $\begin{array}{c}\text { MAV. } 4 . \\
\text { B }\end{array}$ & $\begin{array}{c}\text { MAM.5 } \\
\text {.B }\end{array}$ & MAV.1 & MAV.2 & MAM.1 \\
\hline $\mathrm{SiO} 2$ & 0,032 & 0 & 0,015 & 0,026 & 0,018 & 0,016 & 0,004 & 0,016 & 0,043 & 0,005 & 0,036 & 0,028 & 0,058 & 0,023 & 0,032 & 0,034 \\
\hline $\mathrm{Al} 2 \mathrm{O} 3$ & 0 & 0 & 0 & 0 & 0,024 & 0,014 & 0 & 0 & 0 & 0 & 0 & 0 & 0 & 0 & 0 & 0 \\
\hline $\mathrm{FeO}$ & 0,303 & 0,247 & 0,179 & 0,166 & 0,14 & 0,239 & 0,13 & 0,061 & 0,101 & 0,236 & 0,235 & 0,096 & 0,171 & 0,332 & 0,157 & 0,18 \\
\hline $\mathrm{MnO}$ & 0 & 0,033 & 0 & 0 & 0 & 0 & 0,012 & 0,036 & 0,005 & 0 & 0,004 & 0,024 & 0 & 0,014 & 0 & 0,001 \\
\hline WO3 & 0 & 0 & 0,034 & 0,061 & 0,065 & 0,042 & 0,008 & 0 & 0 & 0,076 & 0,01 & 0 & 0,058 & 0 & 0 & 0 \\
\hline As2O5 & 0 & 0 & 0,018 & 0,019 & 0 & 0 & 0,041 & 0 & 0 & 0 & 0 & 0 & 0,009 & 0 & 0 & 0 \\
\hline Ta2O5 & 0,974 & 0,961 & 0,682 & 0,76 & 0,538 & 0,969 & 0,497 & 0,495 & 0,692 & 0,983 & 1,197 & 0,45 & 0,998 & 1,303 & 0,706 & 0,444 \\
\hline $\mathrm{Sb} 2 \mathrm{O} 5$ & 0,4 & 0,463 & 0,319 & 0,351 & 0,408 & 0,43 & 0,33 & 0,415 & 0,443 & 0,373 & 0,367 & 0,377 & 0,418 & 0,371 & 0,463 & 0,432 \\
\hline $\mathrm{SO} 3$ & 0 & 0,012 & 0 & 0,021 & 0 & 0 & 0 & 0 & 0 & 0 & 0,01 & 0 & 0 & 0 & 0,014 & 0 \\
\hline Bi2O3 & 0 & 0 & 0 & 0,075 & 0 & 0 & 0 & 0 & 0 & 0 & 0,032 & 0 & 0 & 0 & 0,056 & 0 \\
\hline $\mathrm{Nb} 2 \mathrm{O} 5$ & 0,365 & 0,376 & 0,266 & 0,227 & 0,057 & 0,422 & 0,188 & 0,11 & 0,209 & 0,362 & 0,409 & 0,113 & 0,231 & 0,466 & 0,124 & 0,252 \\
\hline $\mathrm{In} 2 \mathrm{O} 3$ & 0,15 & 0,127 & 0,133 & 0,128 & 0,165 & 0,099 & 0,145 & 0,188 & 0,18 & 0,102 & 0,194 & 0,17 & 0,146 & 0,123 & 0,034 & 0,138 \\
\hline $\mathrm{SnO} 2$ & 98,619 & 98,299 & 99,14 & 99,335 & 98,973 & 98,897 & 100,412 & 99,262 & 99,882 & 98,671 & 98,729 & 99,315 & 99,526 & 98,759 & 99,152 & 99,196 \\
\hline UO2 & 0,009 & 0,021 & 0,006 & 0,018 & 0 & 0 & 0,039 & 0 & 0 & 0,006 & 0,056 & 0 & 0 & 0,01 & 0 & 0 \\
\hline $\mathrm{CuO}$ & 0,023 & 0,008 & 0 & 0 & 0,003 & 0 & 0 & 0 & 0 & 0,005 & 0 & 0 & 0 & 0,031 & 0 & 0 \\
\hline $\mathrm{ZnO}$ & 0,023 & 0 & 0 & 0 & 0 & 0 & 0 & 0,032 & 0 & 0,004 & 0,009 & 0 & 0,025 & 0,011 & 0,029 & 0,013 \\
\hline TOTAL & 100,898 & 100,547 & 100,792 & 101,187 & 100,391 & 101,128 & 101,806 & 100,615 & 101,555 & 100,823 & 101,288 & 100,573 & 101,64 & 101,443 & 100,767 & 100,69 \\
\hline \multicolumn{17}{|c|}{ FÓRMULA CALCULADA COM BASE EM 2 OXIGÊNIOS } \\
\hline $\mathrm{Si}$ & 0,00079 & 0,00000 & 0,00037 & 0,00064 & 0,00045 & 0,00040 & 0,00010 & 0,00040 & 0,00106 & 0,00012 & 0,00089 & 0,00070 & 0,00143 & 0,00057 & 0,00080 & 0,00085 \\
\hline $\mathrm{Al}$ & 0,00000 & 0,00000 & 0,00000 & 0,00000 & 0,00071 & 0,00041 & 0,00000 & 0,00000 & 0,00000 & 0,00000 & 0,00000 & 0,00000 & 0,00000 & 0,00000 & 0,00000 & 0,00000 \\
\hline $\mathrm{Fe}$ & 0,00629 & 0,00515 & 0,00372 & 0,00344 & 0,00292 & 0,00495 & 0,00268 & 0,00127 & 0,00208 & 0,00491 & 0,00486 & 0,00200 & 0,00353 & 0,00686 & 0,00327 & 0,00374 \\
\hline $\mathrm{Mn}$ & 0,00000 & 0,00070 & 0,00000 & 0,00000 & 0,00000 & 0,00000 & 0,00025 & 0,00076 & 0,00010 & 0,00000 & 0,00008 & 0,00051 & 0,00000 & 0,00029 & 0,00000 & 0,00002 \\
\hline $\mathrm{W}$ & 0,00000 & 0,00000 & 0,00022 & 0,00039 & 0,00042 & 0,00027 & 0,00005 & 0,00000 & 0,00000 & 0,00049 & 0,00006 & 0,00000 & 0,00037 & 0,00000 & 0,00000 & 0,00000 \\
\hline As & 0,00000 & 0,00000 & 0,00023 & 0,00025 & 0,00000 & 0,00000 & 0,00053 & 0,00000 & 0,00000 & 0,00000 & 0,00000 & 0,00000 & 0,00012 & 0,00000 & 0,00000 & 0,00000 \\
\hline $\mathrm{Ta}$ & 0,00658 & 0,00651 & 0,00461 & 0,00512 & 0,00365 & 0,00653 & 0,00333 & 0,00335 & 0,00464 & 0,00665 & 0,00806 & 0,00305 & 0,00669 & 0,00875 & 0,00478 & 0,00300 \\
\hline $\mathrm{Sb}$ & 0,00369 & 0,00429 & 0,00295 & 0,00323 & 0,00378 & 0,00396 & 0,00302 & 0,00384 & 0,00406 & 0,00344 & 0,00337 & 0,00349 & 0,00383 & 0,00340 & 0,00428 & 0,00399 \\
\hline $\mathrm{S}$ & 0,00000 & 0,00022 & 0,00000 & 0,00039 & 0,00000 & 0,00000 & 0,00000 & 0,00000 & 0,00000 & 0,00000 & 0,00019 & 0,00000 & 0,00000 & 0,00000 & 0,00026 & 0,00000 \\
\hline $\mathrm{Bi}$ & 0,00000 & 0,00000 & 0,00000 & 0,00048 & 0,00000 & 0,00000 & 0,00000 & 0,00000 & 0,00000 & 0,00000 & 0,00020 & 0,00000 & 0,00000 & 0,00000 & 0,00036 & 0,00000 \\
\hline $\mathrm{Nb}$ & 0,00410 & 0,00424 & 0,00299 & 0,00254 & 0,00064 & 0,00472 & 0,00209 & 0,00124 & 0,00233 & 0,00407 & 0,00458 & 0,00127 & 0,00257 & 0,00520 & 0,00139 & 0,00283 \\
\hline In & 0,00161 & 0,00137 & 0,00143 & 0,00137 & 0,00178 & 0,00106 & 0,00155 & 0,00203 & 0,00192 & 0,00110 & 0,00208 & 0,00183 & 0,00156 & 0,00132 & 0,00037 & 0,00149 \\
\hline Sn & 0,97642 & 0,97673 & 0,98285 & 0,98106 & 0,98546 & 0,97661 & 0,98578 & 0,98623 & 0,98261 & 0,97805 & 0,97415 & 0,98691 & 0,97834 & 0,97272 & 0,98331 & 0,98375 \\
\hline $\mathrm{U}$ & 0,00005 & 0,00012 & 0,00003 & 0,00010 & 0,00000 & 0,00000 & 0,00021 & 0,00000 & 0,00000 & 0,00003 & 0,00031 & 0,00000 & 0,00000 & 0,00005 & 0,00000 & 0,00000 \\
\hline $\mathrm{Cu}$ & 0,00043 & 0,00015 & 0,00000 & 0,00000 & 0,00006 & 0,00000 & 0,00000 & 0,00000 & 0,00000 & 0,00009 & 0,00000 & 0,00000 & 0,00000 & 0,00058 & 0,00000 & 0,00000 \\
\hline $\mathrm{Zn}$ & 0,00042 & 0,00000 & 0,00000 & 0,00000 & 0,00000 & 0,00000 & 0,00000 & 0,00059 & 0,00000 & 0,00007 & 0,00016 & 0,00000 & 0,00046 & 0,00020 & 0,00053 & 0,00024 \\
\hline TOTAL & 1,00038 & 0,99947 & 0,99941 & 0,99901 & 0,99988 & 0,99891 & 0,99958 & 0,99971 & 0,99882 & 0,99903 & 0,99900 & 0,99976 & 0,99889 & 0,99995 & 0,99934 & 0,99992 \\
\hline
\end{tabular}




\begin{tabular}{|c|c|c|c|c|c|c|c|c|c|c|c|c|c|c|c|c|}
\hline \multicolumn{9}{|c|}{ ALBITITO (BOA VISTA) } & \multicolumn{8}{|c|}{ ALBITITO (PELOTAS) } \\
\hline AMOSTRA & PA-II & PA-II & PA-1A & PA-1A & PA-1A & PA-1A & PA-1A & PA-1A & FPS-5 & FPS-5 & FPS-5 & FPS-5 & FPS-5 & FPS-5 & FPS-5 & FPS-5 \\
\hline ANÁLISE & MAM.2 & MAM.3 & 1 & 2 & 3 & 4 & 5 & 6 & MAV.1 & MAV.2 & MAV.3 & MAV.4 & MAM.1 & MAM.2 & MAM.3 & MAM.4 \\
\hline $\mathrm{SiO} 2$ & 0,057 & 0 & 0 & 0,012 & 0,008 & 0,008 & 0 & 0 & 0 & 0,011 & 0,04 & 0 & 0,025 & 0,004 & 0,028 & 0,033 \\
\hline $\mathrm{Al} 2 \mathrm{O} 3$ & 0 & 0,004 & 0 & 0 & 0 & 0 & 0,01 & 0,009 & 0 & 0 & 0,007 & 0 & 0,009 & 0 & 0 & 0 \\
\hline $\mathrm{FeO}$ & 0,143 & 0,223 & 0,011 & 0,121 & 0,258 & 0,016 & 0,199 & 0,163 & 0,12 & 0,094 & 0,062 & 0,145 & 0,057 & 0,091 & 0 & 0,121 \\
\hline $\mathrm{MnO}$ & 0 & 0,008 & 0,049 & 0 & 0 & 0,033 & 0 & 0 & 0 & 0,001 & 0 & 0,012 & 0,023 & 0,005 & 0,009 & 0,005 \\
\hline WO3 & 0 & 0 & 0 & 0,136 & 0,055 & 0 & 0,089 & 0 & 0 & 0 & 0 & 0,027 & 0 & 0 & 0 & 0,047 \\
\hline As2O5 & 0 & 0 & 0 & 0,032 & 0 & 0 & 0,054 & 0 & 0 & 0 & 0 & 0 & 0 & 0,047 & 0 & 0,014 \\
\hline Ta2O5 & 0,39 & 0,983 & 0,197 & 0,571 & 0,835 & 0,121 & 0,812 & 0,967 & 0,478 & 0,391 & 0,319 & 0,635 & 0,277 & 0,299 & 0,274 & 0,421 \\
\hline Sb2O5 & 0,337 & 0,41 & 0,327 & 0,442 & 0,407 & 0,356 & 0,307 & 0,236 & 0,354 & 0,36 & 0,539 & 0,359 & 0,414 & 0,32 & 0,434 & 0,448 \\
\hline $\mathrm{SO} 3$ & 0 & 0 & 0 & 0,024 & 0 & 0,037 & 0 & 0 & 0 & 0 & 0,003 & 0 & 0,01 & 0,002 & 0 & 0,013 \\
\hline $\mathrm{Bi} 2 \mathrm{O} 3$ & 0 & 0 & 0 & 0 & 0 & 0 & 0 & 0 & 0 & 0,051 & 0 & 0,035 & 0 & 0,019 & 0,042 & 0 \\
\hline $\mathrm{Nb} 2 \mathrm{O} 5$ & 0,361 & 0,401 & 0,063 & 0,208 & 0,699 & 0,116 & 0,286 & 0,382 & 0,223 & 0,272 & 0,198 & 0,149 & 0,187 & 0,166 & 0,039 & 0,227 \\
\hline $\mathrm{In} 2 \mathrm{O} 3$ & 0,124 & 0,126 & 0,103 & 0,115 & 0,138 & 0,114 & 0,137 & 0,146 & 0,12 & 0,152 & 0,129 & 0,1 & 0,13 & 0,167 & 0,072 & 0,105 \\
\hline $\mathrm{SnO} 2$ & 99,187 & 98,924 & 100,255 & 98,216 & 98,385 & 100,009 & 99,602 & 98,94 & 99,312 & $\begin{array}{l}99,871 \\
\end{array}$ & 100,081 & 100,201 & 100,604 & 99,947 & 100,352 & 99,764 \\
\hline UO2 & 0 & 0 & 0 & 0 & 0 & 0,004 & 0 & 0,035 & 0 & 0 & 0 & 0 & 0 & 0 & 0 & 0,041 \\
\hline $\mathrm{CuO}$ & 0 & 0 & 0 & 0 & 0 & 0 & 0 & 0 & 0,019 & 0 & 0 & 0 & 0 & 0,015 & 0 & 0 \\
\hline $\mathrm{ZnO}$ & 0 & 0 & 0 & 0 & 0 & 0,043 & 0 & 0,043 & 0,004 & 0,011 & 0,004 & 0 & 0 & 0 & 0,088 & 0 \\
\hline TOTAL & 100,599 & 101,079 & 101,005 & 99,877 & 100,785 & 100,857 & 101,496 & 100,921 & 100,63 & 101,214 & 101,382 & 101,663 & 101,736 & 101,082 & 101,338 & 101,239 \\
\hline \multicolumn{17}{|c|}{ FÓRMULA CALCULADA COM BASE EM 2 OXIGÊNIOS } \\
\hline $\mathrm{Si}$ & 0,00142 & 0,00000 & 0,00000 & 0,00030 & 0,00020 & 0,00020 & 0,00000 & 0,00000 & 0,00000 & 0,00027 & 0,00099 & 0,00000 & 0,00062 & 0,00010 & 0,00069 & 0,00082 \\
\hline $\mathrm{Al}$ & 0,00000 & 0,00012 & 0,00000 & 0,00000 & 0,00000 & 0,00000 & 0,00029 & 0,00026 & 0,00000 & 0,00000 & 0,00020 & 0,00000 & 0,00026 & 0,00000 & 0,00000 & 0,00000 \\
\hline $\mathrm{Fe}$ & 0,00297 & 0,00462 & 0,00023 & 0,00254 & 0,00536 & 0,00033 & 0,00411 & 0,00339 & 0,00250 & 0,00195 & 0,00128 & 0,00299 & 0,00117 & 0,00189 & 0,00000 & 0,00250 \\
\hline $\mathrm{Mn}$ & 0,00000 & 0,00017 & 0,00103 & 0,00000 & 0,00000 & 0,00069 & 0,00000 & 0,00000 & 0,00000 & 0,00002 & 0,00000 & 0,00025 & 0,00048 & 0,00010 & 0,00019 & 0,00010 \\
\hline W & 0,00000 & 0,00000 & 0,00000 & 0,00088 & 0,00035 & 0,00000 & 0,00057 & 0,00000 & 0,00000 & 0,00000 & 0,00000 & 0,00017 & 0,00000 & 0,00000 & 0,00000 & 0,00030 \\
\hline As & 0,00000 & 0,00000 & 0,00000 & 0,00042 & 0,00000 & 0,00000 & 0,00070 & 0,00000 & 0,00000 & 0,00000 & 0,00000 & 0,00000 & 0,00000 & 0,00061 & 0,00000 & 0,00018 \\
\hline $\mathrm{Ta}$ & 0,00264 & 0,00663 & 0,00133 & 0,00389 & 0,00564 & 0,00082 & 0,00545 & 0,00653 & 0,00324 & 0,00263 & 0,00214 & 0,00426 & 0,00185 & 0,00202 & 0,00184 & 0,00283 \\
\hline $\mathrm{Sb}$ & 0,00311 & 0,00378 & 0,00302 & 0,00412 & 0,00375 & 0,00328 & 0,00282 & 0,00218 & 0,00328 & 0,00331 & 0,00494 & 0,00329 & 0,00379 & 0,00295 & 0,00399 & 0,00412 \\
\hline $\mathrm{S}$ & 0,00000 & 0,00000 & 0,00000 & 0,00045 & 0,00000 & 0,00069 & 0,00000 & 0,00000 & 0,00000 & 0,00000 & 0,00006 & 0,00000 & 0,00018 & 0,00004 & 0,00000 & 0,00024 \\
\hline $\mathrm{Bi}$ & 0,00000 & 0,00000 & 0,00000 & 0,00000 & 0,00000 & 0,00000 & 0,00000 & 0,00000 & 0,00000 & 0,00033 & 0,00000 & 0,00022 & 0,00000 & 0,00012 & 0,00027 & 0,00000 \\
\hline $\mathrm{Nb}$ & 0,00406 & 0,00449 & 0,00071 & 0,00236 & 0,00785 & 0,00130 & 0,00319 & 0,00429 & 0,00251 & 0,00304 & 0,00221 & 0,00166 & 0,00208 & 0,00186 & 0,00044 & 0,00254 \\
\hline In & 0,00134 & 0,00135 & 0,00111 & 0,00125 & 0,00148 & 0,00123 & 0,00146 & 0,00157 & 0,00129 & 0,00163 & 0,00138 & 0,00107 & 0,00139 & 0,00179 & 0,00077 & 0,00112 \\
\hline Sn & 0,98383 & 0,97788 & 0,99223 & 0,98201 & 0,97394 & 0,99017 & 0,98058 & 0,98009 & 0,98628 & 0,98594 & 0,98544 & 0,98564 & 0,98740 & 0,98798 & 0,98980 & 0,98391 \\
\hline $\mathrm{U}$ & 0,00000 & 0,00000 & 0,00000 & 0,00000 & 0,00000 & 0,00002 & 0,00000 & 0,00019 & 0,00000 & 0,00000 & 0,00000 & 0,00000 & 0,00000 & 0,00000 & 0,00000 & 0,00023 \\
\hline $\mathrm{Cu}$ & 0,00000 & 0,00000 & 0,00000 & 0,00000 & 0,00000 & 0,00000 & 0,00000 & 0,00000 & 0,00036 & 0,00000 & 0,00000 & 0,00000 & 0,00000 & 0,00028 & 0,00000 & 0,00000 \\
\hline $\mathrm{Zn}$ & 0,00000 & 0,00000 & 0,00000 & 0,00000 & 0,00000 & 0,00079 & 0,00000 & 0,00079 & 0,00007 & 0,00020 & 0,00007 & 0,00000 & 0,00000 & 0,00000 & 0,00161 & 0,00000 \\
\hline TOTAL & 0,99937 & 0,99904 & 0,99964 & 0,99822 & 0,99856 & 0,99952 & 0,99917 & 0,99930 & 0,99953 & 0,99933 & 0,99872 & 0,99955 & 0,99922 & 0,99974 & 0,99959 & 0,99890 \\
\hline
\end{tabular}




\begin{tabular}{|c|c|c|c|c|c|c|c|c|c|c|c|c|c|c|c|c|}
\hline \multicolumn{17}{|c|}{ ALBITITO (PELOTAS) } \\
\hline AMOSTRA & $\begin{array}{c}\text { PS-8-8- } \\
35,20\end{array}$ & $\begin{array}{c}\text { PS-8-8- } \\
35,20\end{array}$ & $\begin{array}{c}\text { PS-8-8- } \\
35,20\end{array}$ & $\begin{array}{c}\text { PS-8-8- } \\
35,20\end{array}$ & $\begin{array}{c}\text { PS-8-8- } \\
35,20\end{array}$ & $\begin{array}{c}\text { PS-8-8- } \\
35,20\end{array}$ & $\begin{array}{c}\text { PS-8-8- } \\
35,20\end{array}$ & $\begin{array}{c}\text { PS-8-8- } \\
35,20\end{array}$ & $\begin{array}{c}\text { PS-8-8- } \\
35,20\end{array}$ & $\begin{array}{c}\text { PS-8-8- } \\
35,20\end{array}$ & $\begin{array}{c}\text { FPS-8-8- } \\
35,20\end{array}$ & $\begin{array}{c}\text { FPS-8-8- } \\
35,20\end{array}$ & $\begin{array}{l}\text { FPS-8- } \\
8-35,20\end{array}$ & $\begin{array}{c}\text { FPS-8-8- } \\
35,20\end{array}$ & $\begin{array}{l}\text { FPS-8- } \\
8-35,20\end{array}$ & $\begin{array}{c}\text { FPS-8-8- } \\
35,20\end{array}$ \\
\hline ANÁLISE & $1 . \mathrm{B}$ & $1 . \mathrm{N}$ & MAV.2 & MAM.2 & MAV.3 & MAV.4 & MAV.5 & MAM.3 & MAM.4 & MAM.5 & $1 . \mathrm{B}$ & $1 . \mathrm{N}$ & $2 . \mathrm{B}$ & $2 . \mathrm{N}$ & $3 . \mathrm{N}$ & $4 . \mathrm{N}$ \\
\hline $\mathrm{SiO} 2$ & 0 & 0,027 & 0 & 0,002 & 0,01 & 0,002 & 0,031 & 0 & 0,098 & 0,014 & 0,051 & 0,032 & 0,035 & 0,052 & 0,052 & 0,02 \\
\hline $\mathrm{Al} 2 \mathrm{O} 3$ & 0,011 & 0 & 0 & 0 & 0 & 0 & 0 & 0 & 0,015 & 0,007 & 0 & 0,001 & 0 & 0,015 & 0,009 & 0 \\
\hline $\mathrm{FeO}$ & 0,204 & 0,344 & 0,125 & 0,24 & 0,136 & 0,167 & 0,058 & 0,218 & 0,242 & 0,004 & 0,251 & 0,162 & 0,106 & 0,237 & 0,141 & 0,001 \\
\hline $\mathrm{MnO}$ & 0,014 & 0 & 0 & 0 & 0,024 & 0,005 & 0 & 0,013 & 0,025 & 0,033 & 0,027 & 0 & 0 & 0 & 0 & 0,012 \\
\hline WO3 & 0 & 0,019 & 0 & 0 & 0 & 0,022 & 0 & 0 & 0 & 0 & 0 & 0 & 0,021 & 0 & 0 & 0 \\
\hline As2O5 & 0 & 0,035 & 0 & 0 & 0 & 0,026 & 0 & 0 & 0 & 0,059 & 0 & 0 & 0 & 0 & 0,017 & 0 \\
\hline Ta2O5 & 0,934 & 1,264 & 0,508 & 0,88 & 0,549 & 0,774 & 0,407 & 0,733 & 0,725 & 0,114 & 1,221 & 0,662 & 0,424 & 0,873 & 0,446 & 0,111 \\
\hline Sb2O5 & 0,4 & 0,381 & 0,396 & 0,411 & 0,389 & 0,455 & 0,341 & 0,331 & 0,355 & 0,405 & 0,344 & 0,341 & 0,369 & 0,378 & 0,351 & 0,312 \\
\hline $\mathrm{SO} 3$ & 0 & 0,003 & 0 & 0 & 0 & 0 & 0 & 0 & 0 & 0 & 0,011 & 0,029 & 0 & 0 & 0 & 0 \\
\hline $\mathrm{Bi} 2 \mathrm{O} 3$ & 0,051 & 0,029 & 0 & 0 & 0,081 & 0,015 & 0,015 & 0 & 0 & 0 & 0,011 & 0 & 0 & 0 & 0 & 0,005 \\
\hline $\mathrm{Nb} 2 \mathrm{O} 5$ & 0,536 & 0,498 & 0,227 & 0,636 & 0,238 & 0,327 & 0,184 & 0,518 & 0,664 & 0,181 & 0,384 & 0,659 & 0,195 & 0,369 & 0,337 & 0,046 \\
\hline In2O3 & 0,184 & 0,071 & 0,053 & 0,159 & 0,121 & 0,149 & 0,112 & 0,143 & 0,172 & 0,107 & 0,146 & 0,143 & 0,12 & 0,099 & 0,089 & 0,109 \\
\hline $\mathrm{SnO} 2$ & 99,213 & 98,614 & 99,446 & 98,978 & 99,564 & 98,814 & 99,644 & 99,364 & 97,743 & 100,275 & 98,382 & 98,336 & 100,337 & 99,022 & 99,695 & 100,504 \\
\hline UO2 & 0,025 & 0 & 0 & 0 & 0,051 & 0 & 0,05 & 0,049 & 0 & 0,017 & 0 & 0,04 & 0,024 & 0,059 & 0 & 0,047 \\
\hline $\mathrm{CuO}$ & 0 & 0,04 & 0,009 & 0 & 0 & 0 & 0 & 0 & 0 & 0,014 & 0,023 & 0 & 0 & 0 & 0 & 0 \\
\hline $\mathrm{ZnO}$ & 0,02 & 0 & 0 & 0 & 0,012 & 0 & 0 & 0 & 0,013 & 0 & 0 & 0 & 0,064 & 0,029 & 0,047 & 0,012 \\
\hline TOTAL & 101,592 & 101,325 & 100,764 & 101,306 & 101,175 & 100,756 & 100,842 & 101,369 & 100,052 & 101,23 & 100,851 & $\begin{array}{l}100,405 \\
\end{array}$ & 101,695 & $\begin{array}{l}101,133 \\
\end{array}$ & 101,184 & 101,179 \\
\hline \multicolumn{17}{|c|}{ FÓRMULA CALCULADA COM BASE EM 2 OXIGÊNIOS } \\
\hline $\mathrm{Si}$ & 0,00000 & 0,00067 & 0,00000 & 0,00005 & 0,00025 & 0,00005 & 0,00077 & 0,00000 & 0,00245 & 0,00035 & 0,00127 & 0,00080 & 0,00086 & 0,00129 & 0,00129 & 0,00050 \\
\hline $\mathrm{Al}$ & 0,00032 & 0,00000 & 0,00000 & 0,00000 & 0,00000 & 0,00000 & 0,00000 & 0,00000 & 0,00044 & 0,00020 & 0,00000 & 0,00003 & 0,00000 & 0,00044 & 0,00026 & 0,00000 \\
\hline $\mathrm{Fe}$ & 0,00421 & 0,00711 & 0,00260 & 0,00496 & 0,00282 & 0,00347 & 0,00121 & 0,00450 & 0,00505 & 0,00008 & 0,00521 & 0,00337 & 0,00218 & 0,00491 & 0,00292 & 0,00002 \\
\hline $\mathrm{Mn}$ & 0,00029 & 0,00000 & 0,00000 & 0,00000 & 0,00050 & 0,00011 & 0,00000 & 0,00027 & 0,00053 & 0,00069 & 0,00057 & 0,00000 & 0,00000 & 0,00000 & 0,00000 & 0,00025 \\
\hline W & 0,00000 & 0,00012 & 0,00000 & 0,00000 & 0,00000 & 0,00014 & 0,00000 & 0,00000 & 0,00000 & 0,00000 & 0,00000 & 0,00000 & 0,00013 & 0,00000 & 0,00000 & 0,00000 \\
\hline As & 0,00000 & 0,00045 & 0,00000 & 0,00000 & 0,00000 & 0,00034 & 0,00000 & 0,00000 & 0,00000 & 0,00076 & 0,00000 & 0,00000 & 0,00000 & 0,00000 & 0,00022 & 0,00000 \\
\hline $\mathrm{Ta}$ & 0,00626 & 0,00850 & 0,00344 & 0,00591 & 0,00370 & 0,00523 & 0,00275 & 0,00493 & 0,00492 & 0,00077 & 0,00825 & 0,00448 & 0,00284 & 0,00588 & 0,00300 & 0,00075 \\
\hline $\mathrm{Sb}$ & 0,00366 & 0,00350 & 0,00366 & 0,00377 & 0,00358 & 0,00420 & 0,00315 & 0,00304 & 0,00329 & 0,00372 & 0,00317 & 0,00315 & 0,00338 & 0,00348 & 0,00322 & 0,00287 \\
\hline $\mathrm{S}$ & 0,00000 & 0,00006 & 0,00000 & 0,00000 & 0,00000 & 0,00000 & 0,00000 & 0,00000 & 0,00000 & 0,00000 & 0,00021 & 0,00054 & 0,00000 & 0,00000 & 0,00000 & 0,00000 \\
\hline $\mathrm{Bi}$ & 0,00032 & 0,00018 & 0,00000 & 0,00000 & 0,00052 & 0,00010 & 0,00010 & 0,00000 & 0,00000 & 0,00000 & $\begin{array}{l}0,00007 \\
\end{array}$ & 0,00000 & 0,00000 & 0,00000 & 0,00000 & 0,00003 \\
\hline $\mathrm{Nb}$ & 0,00598 & 0,00556 & 0,00255 & 0,00710 & 0,00267 & 0,00368 & 0,00207 & 0,00579 & 0,00750 & 0,00202 & 0,00431 & 0,00742 & 0,00217 & 0,00413 & 0,00377 & 0,00052 \\
\hline In & 0,00196 & 0,00076 & 0,00057 & 0,00170 & 0,00130 & 0,00160 & 0,00120 & 0,00153 & 0,00186 & 0,00115 & 0,00157 & 0,00154 & 0,00128 & 0,00106 & 0,00095 & 0,00117 \\
\hline Sn & 0,97559 & 0,97192 & $\begin{array}{l}0,98613 \\
\end{array}$ & \begin{tabular}{|l|}
0,97521 \\
\end{tabular} & 0,98390 & 0,97986 & 0,98742 & 0,97901 & 0,97327 & 0,98894 & $\begin{array}{l}0,97442 \\
\end{array}$ & $\begin{array}{l}0,97648 \\
\end{array}$ & 0,98568 & $\begin{array}{l}0,97769 \\
\end{array}$ & 0,98315 & 0,99293 \\
\hline $\mathrm{U}$ & 0,00014 & 0,00000 & 0,00000 & 0,00000 & 0,00028 & 0,00000 & 0,00028 & 0,00027 & 0,00000 & 0,00009 & 0,00000 & 0,00022 & 0,00013 & 0,00033 & 0,00000 & 0,00026 \\
\hline $\mathrm{Cu}$ & 0,00000 & 0,00075 & 0,00017 & 0,00000 & 0,00000 & 0,00000 & 0,00000 & 0,00000 & 0,00000 & 0,00026 & 0,00043 & 0,00000 & 0,00000 & 0,00000 & 0,00000 & 0,00000 \\
\hline $\mathrm{Zn}$ & 0,00036 & 0,00000 & 0,00000 & 0,00000 & 0,00022 & 0,00000 & 0,00000 & 0,00000 & 0,00024 & 0,00000 & 0,00000 & 0,00000 & 0,00116 & 0,00053 & 0,00086 & 0,00022 \\
\hline TOTAL & 0,99911 & 0,99957 & $\begin{array}{l}0,99912 \\
\end{array}$ & 0,99871 & 0,99974 & 0,99878 & 0,99894 & 0,99933 & 0,99956 & 0,99904 & $\begin{array}{l}0,99948 \\
\end{array}$ & $\begin{array}{l}0,99804 \\
\end{array}$ & 0,99983 & $\begin{array}{l}0,99972 \\
\end{array}$ & 0,99964 & 0,99951 \\
\hline
\end{tabular}


Rochas albitizadas e albititos relacionados a mineralizações de estanho da Província Estanífera de Goiás: caracterização petrológica e gênese.

\section{ANEXO 05}

\section{QUÍMICA MINERAL}

DA APATITA 


\begin{tabular}{|c|c|c|c|c|c|c|c|c|c|c|c|c|c|}
\hline \multicolumn{14}{|c|}{ ALBITITO (BOA VISTA) } \\
\hline AMOSTRA & PA-1A' & PA-1A' & PA-1A' & PA-1A' & PA-1A' & PA-1AP & PA-1AP & PA-1AP & PA-1AP & PA-1AP & PA-1D & PA-1D & PA-1D \\
\hline ANÁLISE & 1.1 & 1.2 & 1.3 & 1.4 & 1.5 & 1.1 & 1.2 & 1.3 & 1.4 & 1.5 & 1.1 & 1.2 & 2 \\
\hline $\mathrm{P} 2 \mathrm{O} 5$ & 42,613 & 42,813 & 42,549 & 43,001 & 44,092 & 43,25 & 43,537 & 43,992 & 43,17 & 42,118 & 43,397 & 42,823 & 41,803 \\
\hline $\mathrm{SiO} 2$ & 0 & 0,007 & 0 & 0,02 & 0 & 0 & 0 & 0 & 0,007 & 0 & 0 & 0,025 & 0 \\
\hline $\mathrm{TiO} 2$ & n.a & n.a & n.a & n.a & n.a & n.a & n.a & n.a & n.a & n.a & n.a & n.a & n.a \\
\hline $\mathrm{Al} 2 \mathrm{O} 3$ & 0 & 0 & 0,024 & 0,023 & 0 & 0 & 0,043 & 0 & 0,008 & 0 & 0 & 0 & 0 \\
\hline $\mathrm{FeO}$ & 0,04 & 0,051 & 0,159 & 0,223 & 0,288 & 0,073 & 0,136 & 0,088 & 0,021 & 0,036 & 0,135 & 0,153 & 0,243 \\
\hline $\mathrm{MnO}$ & 2,931 & 3,268 & 3,116 & 2,904 & 2,701 & 1,615 & 1,379 & 2,21 & 1,818 & 2,253 & 2,278 & 1,383 & 2,355 \\
\hline $\mathrm{MgO}$ & 0 & 0,011 & 0,032 & 0 & 0,001 & 0 & 0 & 0 & 0,008 & 0,004 & 0,014 & 0,046 & 0,009 \\
\hline $\mathrm{CaO}$ & 53,166 & 53,093 & 53,018 & 52,965 & 53,712 & 54,408 & 54,755 & 53,546 & 54,905 & 49,347 & 54,022 & 53,703 & 53,277 \\
\hline $\mathrm{Na} 2 \mathrm{O}$ & 0,039 & 0 & 0,076 & 0,018 & 0,047 & 0 & 0,002 & 0 & 0,01 & 0 & 0,024 & 0,103 & 0,012 \\
\hline $\mathrm{K} 2 \mathrm{O}$ & 0 & 0,012 & 0,027 & 0 & 0 & 0,001 & 0,002 & 0 & 0,017 & 0,027 & 0,023 & 0,015 & 0 \\
\hline $\mathrm{SrO}$ & 0,102 & 0,038 & 0,01 & 0,006 & 0,042 & 0,171 & 0,155 & 0,347 & 0,552 & 5,958 & 0,006 & 0 & 0,048 \\
\hline $\mathrm{BaO}$ & 0 & 0,141 & 0 & 0 & 0,011 & 0 & 0,034 & 0 & 0 & 0 & 0 & 0,077 & 0 \\
\hline ThO2 & 0 & 0,015 & 0,034 & 0 & 0 & 0,03 & 0 & 0,023 & 0,006 & 0,003 & 0 & 0,002 & 0 \\
\hline $\mathrm{NiO}$ & 0,004 & 0,069 & 0,037 & 0,007 & 0,007 & 0,011 & 0 & 0,04 & 0 & 0,014 & 0 & 0 & 0,007 \\
\hline V2O5 & 0,09 & 0 & 0,012 & 0,024 & 0,012 & 0 & 0 & 0,019 & 0,025 & 0 & 0,046 & 0 & 0,084 \\
\hline $\mathrm{Nb} 2 \mathrm{O} 5$ & 0,028 & 0 & 0 & 0,006 & 0 & 0,072 & 0,067 & 0,052 & 0 & 0,059 & 0,002 & 0,002 & 0,042 \\
\hline $\mathrm{La} 2 \mathrm{O} 3$ & 0,01 & 0 & 0 & 0,05 & 0 & 0,008 & 0,015 & 0,006 & 0 & 0 & 0,017 & 0,004 & 0,008 \\
\hline $\mathrm{Ce} 2 \mathrm{O} 3$ & 0,003 & 0,069 & 0 & 0,093 & 0,003 & 0,038 & 0,014 & 0,067 & 0,115 & 0,174 & 0,064 & 0 & 0 \\
\hline $\begin{array}{l}\mathrm{Pr} 2 \mathrm{O} 3 \\
\end{array}$ & 0 & 0 & 0,082 & 0,016 & 0,018 & 0,039 & 0 & 0,019 & 0 & 0 & 0,019 & 0,046 & 0 \\
\hline $\mathrm{Nd} 2 \mathrm{O} 3$ & 0,08 & 0,013 & 0 & 0 & 0,031 & 0,105 & 0,018 & 0,056 & 0,014 & 0,202 & 0 & 0,017 & 0,1 \\
\hline $\mathrm{Sm} 2 \mathrm{O} 3$ & 0 & 0 & 0 & 0 & 0 & 0 & 0 & 0,045 & 0 & 0 & 0 & 0 & 0 \\
\hline $\mathrm{Eu} 2 \mathrm{O} 3$ & 0,057 & 0 & 0 & 0 & 0,013 & 0 & 0,041 & 0,016 & 0 & 0 & 0,056 & 0,036 & 0,03 \\
\hline $\mathrm{Gd} 2 \mathrm{O} 3$ & 0 & 0,006 & 0,006 & 0 & 0 & 0,004 & 0 & 0,008 & 0,021 & 0,005 & 0 & 0,01 & 0 \\
\hline $\mathrm{Tb} 2 \mathrm{O} 3$ & 0,066 & 0 & 0,058 & 0,002 & 0,061 & 0,137 & 0,113 & 0 & 0 & 0 & 0 & 0,027 & 0 \\
\hline Dy2O3 & 0 & 0,014 & 0 & 0,015 & 0,012 & 0,009 & 0,014 & 0,006 & 0,004 & 0 & 0 & 0,001 & 0 \\
\hline $\mathrm{Ho} 2 \mathrm{O} 3$ & 0 & 0 & 0 & 0 & 0 & 0 & 0 & 0 & 0,001 & 0 & 0 & 0 & 0 \\
\hline $\mathrm{Yb} 2 \mathrm{O} 3$ & 0 & 0 & 0,006 & 0,014 & 0 & 0 & 0,013 & 0,027 & 0 & 0 & 0,034 & 0 & 0 \\
\hline $\mathrm{Lu} 2 \mathrm{O} 3$ & 0,048 & 0,057 & 0 & 0,057 & 0,029 & 0,049 & 0 & 0,003 & 0,034 & 0 & 0,105 & 0 & 0,088 \\
\hline $\mathrm{F}$ & 5,891 & 6,204 & 5,044 & 4,778 & 4,34 & 5,006 & 5,007 & 5,324 & 11,974 & 4,473 & 5,898 & 6,577 & 5,049 \\
\hline $\mathrm{Cl}$ & 0 & 0,011 & 0,019 & 0 & 0,021 & 0 & 0 & 0,019 & 0,001 & 0,015 & 0,006 & 0,01 & 0,006 \\
\hline $\mathrm{H}_{2} \mathrm{O}^{*}$ & 0,45 & 0,38 & 0,64 & 0,71 & 0,84 & 0,67 & 0,68 & 0,61 & 0,00 & 0,74 & 0,47 & 0,29 & 0,62 \\
\hline Total & 100,99 & 101,57 & 101,11 & 101,21 & 102,97 & 101,62 & 102,12 & 102,32 & 103,87 & 101,75 & 102,02 & 100,46 & 99,78 \\
\hline \multicolumn{14}{|c|}{ FÓRMULA CALCULADA COM BASE EM 25 OXIGÊNIOS } \\
\hline $\mathrm{P}$ & 6,022 & 6,024 & 6,010 & 6,047 & 6,081 & 6,047 & 6,051 & 6,100 & 6,006 & 6,046 & 6,049 & 6,053 & 5,986 \\
\hline Si & 0,000 & 0,001 & 0,000 & 0,003 & 0,000 & 0,000 & 0,000 & 0,000 & 0,001 & 0,000 & 0,000 & 0,004 & 0,000 \\
\hline $\mathrm{Ti}$ & 0,000 & 0,000 & 0,000 & 0,000 & 0,000 & 0,000 & 0,000 & 0,000 & 0,000 & 0,000 & 0,000 & 0,000 & 0,000 \\
\hline $\mathrm{Al}$ & 0,000 & 0,000 & 0,002 & 0,002 & 0,000 & 0,000 & 0,004 & 0,000 & 0,001 & 0,000 & 0,000 & 0,000 & 0,000 \\
\hline $\mathrm{Fe}$ & 0,006 & 0,007 & 0,022 & 0,031 & 0,039 & 0,010 & 0,019 & 0,012 & 0,003 & 0,005 & 0,019 & 0,021 & 0,034 \\
\hline $\mathrm{Mn}$ & 0,414 & 0,460 & 0,440 & 0,409 & 0,373 & 0,226 & 0,192 & 0,307 & 0,253 & 0,324 & 0,318 & 0,196 & 0,337 \\
\hline
\end{tabular}




\begin{tabular}{|c|c|c|c|c|c|c|c|c|c|c|c|c|c|}
\hline $\mathrm{Mg}$ & 0,000 & 0,003 & 0,008 & 0,000 & 0,000 & 0,000 & 0,000 & 0,000 & 0,002 & 0,001 & 0,003 & 0,011 & 0,002 \\
\hline $\mathrm{Ca}$ & 9,509 & 9,454 & 9,478 & 9,426 & 9,374 & 9,627 & 9,632 & 9,397 & 9,667 & 8,965 & 9,530 & 9,607 & 9,655 \\
\hline $\mathrm{Na}$ & 0,013 & 0,000 & 0,025 & 0,006 & 0,015 & 0,000 & 0,001 & 0,000 & 0,003 & 0,000 & 0,008 & 0,033 & 0,004 \\
\hline $\mathrm{K}$ & 0,000 & 0,003 & 0,006 & 0,000 & 0,000 & 0,000 & 0,000 & 0,000 & 0,004 & 0,006 & 0,005 & 0,003 & 0,000 \\
\hline $\mathrm{Sr}$ & 0,010 & 0,004 & 0,001 & 0,001 & 0,004 & 0,016 & 0,015 & 0,033 & 0,053 & 0,586 & 0,001 & 0,000 & 0,005 \\
\hline $\mathrm{Ba}$ & 0,000 & 0,009 & 0,000 & 0,000 & 0,001 & 0,000 & 0,002 & 0,000 & 0,000 & 0,000 & 0,000 & 0,005 & 0,000 \\
\hline Th & 0,000 & 0,001 & 0,001 & 0,000 & 0,000 & 0,001 & 0,000 & 0,001 & 0,000 & 0,000 & 0,000 & 0,000 & 0,000 \\
\hline $\mathrm{Ni}$ & 0,0005 & 0,0092 & 0,0049 & 0,0009 & 0,0009 & 0,0014 & 0 & 0,0052 & 0 & 0,0019 & 0 & 0 & 0,0010 \\
\hline $\mathrm{V}$ & 0,0099 & 0 & 0,0013 & 0,0026 & 0,0012 & 0 & 0 & 0,0020 & 0,0027 & 0 & 0,0049 & 0 & 0,0094 \\
\hline $\mathrm{Nb}$ & 0,0021 & 0 & 0 & 0,0004 & 0 & 0,0053 & 0,0049 & 0,0038 & 0 & 0,0046 & 0,0001 & 0,0001 & 0,0032 \\
\hline $\mathrm{La}$ & 0,0006 & 0 & 0 & 0,0030 & 0 & 0,0004 & 0,0009 & 0,0003 & 0 & 0 & 0,0010 & 0,0002 & 0,0005 \\
\hline $\mathrm{Ce}$ & 0,0001 & 0,0041 & 0 & 0,0056 & 0,0001 & 0,0022 & 0,0008 & 0,0040 & 0,0069 & 0,0110 & 0,0038 & 0 & 0,0000 \\
\hline $\operatorname{Pr}$ & 0 & 0 & 0,0049 & 0,0009 & 0,0010 & 0,0023 & 0 & 0,0011 & 0 & 0 & 0,0011 & 0,0027 & 0,0000 \\
\hline $\mathrm{Nd}$ & 0,0047 & 0,0007 & 0 & 0 & 0,0018 & 0,0061 & 0,0010 & 0,0032 & 0,0008 & 0,0125 & 0 & 0,0010 & 0,0060 \\
\hline $\mathrm{Sm}$ & 0,0000 & 0,0000 & 0,0000 & 0,0000 & 0,0000 & 0,0000 & 0,0000 & 0,0025 & 0,0000 & 0,0000 & 0,0000 & 0,0000 & 0,0000 \\
\hline $\mathrm{Eu}$ & 0,0032 & 0,0000 & 0,0000 & 0,0000 & 0,0007 & 0,0000 & 0,0023 & 0,0009 & 0,0000 & 0,0000 & 0,0031 & 0,0021 & 0,0017 \\
\hline $\mathrm{Gd}$ & 0,0000 & 0,0003 & 0,0003 & 0,0000 & 0,0000 & 0,0002 & 0,0000 & 0,0004 & 0,0011 & 0,0003 & 0,0000 & 0,0006 & 0,0000 \\
\hline $\mathrm{Tb}$ & 0,0000 & 0,0000 & 0,0000 & 0,0000 & 0,0000 & 0,0000 & 0,0000 & 0,0000 & 0,0000 & 0,0000 & 0,0000 & 0,0000 & 0,0000 \\
\hline Dy & 0,0035 & 0,0000 & 0,0031 & 0,0001 & 0,0032 & 0,0073 & 0,0060 & 0,0000 & 0,0000 & 0,0000 & 0,0000 & 0,0015 & 0,0000 \\
\hline Ho & 0,0000 & 0,0007 & 0,0000 & 0,0008 & 0,0006 & 0,0005 & 0,0007 & 0,0003 & 0,0002 & 0,0000 & 0,0000 & 0,0001 & 0,0000 \\
\hline $\mathrm{Yb}$ & 0,0000 & 0,0000 & 0,0003 & 0,0007 & 0,0000 & 0,0000 & 0,0007 & 0,0013 & 0,0000 & 0,0000 & 0,0017 & 0,0000 & 0,0000 \\
\hline $\mathrm{Lu}$ & 0,0024 & 0,0029 & 0,0000 & 0,0029 & 0,0014 & 0,0024 & 0,0000 & 0,0001 & 0,0017 & 0,0000 & 0,0052 & 0,0000 & 0,0045 \\
\hline $\mathrm{F}$ & 1,501 & 1,574 & 1,284 & 1,211 & 1,079 & 1,262 & 1,255 & 1,331 & 3,003 & 1,158 & 1,482 & 1,676 & 1,303 \\
\hline $\mathrm{Cl}$ & 0,000 & 0,003 & 0,005 & 0,000 & 0,006 & 0,000 & 0,000 & 0,005 & 0,000 & 0,004 & 0,002 & 0,003 & 0,002 \\
\hline $\mathrm{H} 2 \mathrm{O}^{*}$ & 0,499 & 0,423 & 0,710 & 0,789 & 0,915 & 0,738 & 0,745 & 0,664 & 0,000 & 0,838 & 0,516 & 0,321 & 0,695 \\
\hline Total & 17,973 & 17,964 & $\begin{array}{c}17,994 \\
\end{array}$ & 17,925 & 17,887 & 17,928 & 17,915 & $\begin{array}{ll}17,849 \\
\end{array}$ & 18,995 & 17,933 & 17,932 & 17,934 & 18,023 \\
\hline Sitio P & 6,022 & 6,025 & 6,010 & 6,050 & 6,081 & 6,047 & 6,051 & 6,100 & 6,007 & 6,046 & 6,049 & 6,057 & 5,986 \\
\hline Sitio $\mathrm{Ca}$ & 9,951 & $\begin{array}{r}9,939 \\
\end{array}$ & $\begin{array}{l}9,982 \\
\end{array}$ & 9,874 & 9,806 & 9,880 & 9,864 & 9,748 & 9,985 & \begin{tabular}{|c|}
9,887 \\
\end{tabular} & 9,883 & $\begin{array}{l}9,877 \\
\end{array}$ & 10,037 \\
\hline $\begin{array}{c}\text { Sitio } \\
(\mathrm{F}, \mathrm{Cl}, \mathrm{OH})\end{array}$ & 2,000 & 2,000 & 2,000 & 2,000 & 2,000 & 2,000 & 2,000 & 2,000 & 3,003 & 2,000 & 2,000 & 2,000 & 2,000 \\
\hline
\end{tabular}

Continuação 


\begin{tabular}{|c|c|c|c|c|c|c|c|c|c|c|c|c|}
\hline \multicolumn{8}{|c|}{ ALBITITO (PELOTAS) } & \multicolumn{5}{|c|}{ ALBITITO (BOA VISTA) } \\
\hline AMOSTRA & $\begin{array}{l}\text { PA-1D } \\
\text { C2.1.1 }\end{array}$ & FPS-5 & FPS-5 & FPS-5 & FPS-5 & FPS-5 & FPS-5 & MA-10 & MA-10 & MA-10 & MA-10 & MA-10 \\
\hline ANÁLISE & 2 & 1.1 & 1.2 & 1.3 & 1.4 & 1.5 & 1.6 & $1 . \mathrm{b}$ & $1 . \mathrm{n}$ & $2 . n$ & $2 . \mathrm{b}$ & 2 \\
\hline $\mathrm{P} 2 \mathrm{O} 5$ & 41,803 & 41,351 & 42,215 & 42,424 & 42,032 & 42,435 & 42,065 & 42,317 & 40,605 & 41,587 & 42,308 & 41,702 \\
\hline $\mathrm{SiO} 2$ & 0 & 0 & 0 & 0,011 & 0 & 0,011 & 0 & 0 & 0 & 0 & 0 & 0 \\
\hline $\mathrm{TiO} 2$ & 0 & 0,004 & 0 & 0 & 0 & 0 & 0 & 0,019 & 0 & 0 & 0 & 0 \\
\hline $\mathrm{Al} 2 \mathrm{O} 3$ & 0 & 0 & 0 & 0 & 0 & 0 & 0,001 & 0 & 0,002 & 0 & 0,014 & 0,007 \\
\hline $\mathrm{FeO}$ & 0,243 & 0,305 & 0,294 & 0,131 & 0,33 & 0,065 & 0 & 0,665 & 0,614 & 0,774 & 0,406 & 0,628 \\
\hline $\mathrm{MnO}$ & 2,355 & 2,932 & 3,124 & 3,012 & 3,003 & 4,015 & 2,794 & 2,292 & 2,553 & 2,364 & 1,818 & 2,528 \\
\hline $\mathrm{MgO}$ & 0,009 & 0,024 & 0 & 0,005 & 0,01 & 0 & 0,002 & 0 & 0,007 & 0 & 0,021 & 0 \\
\hline $\mathrm{CaO}$ & 53,277 & 52,757 & 52,041 & 51,674 & 52,995 & 52,193 & 53,267 & 52,464 & 52,17 & 52,756 & 53,03 & 52,615 \\
\hline $\mathrm{Na} 2 \mathrm{O}$ & 0,012 & 0,283 & 0,086 & 0,151 & 0,006 & 0,006 & 0,047 & 0 & 0 & 0,012 & 0 & 0 \\
\hline $\mathrm{K} 2 \mathrm{O}$ & 0 & 0,458 & 0,015 & 0,002 & 0,047 & 0,016 & 0,041 & 0 & 0,016 & 0 & 0 & 0 \\
\hline $\mathrm{SrO}$ & 0,048 & 0,068 & 0 & 0,047 & 0,045 & 0,036 & 0,019 & 0,127 & 0,054 & 0,048 & 0,081 & 0,1 \\
\hline $\mathrm{BaO}$ & 0 & 0,086 & 0 & 0 & 0,043 & 0,008 & 0,079 & 0 & 0,036 & 0,101 & 0 & 0,043 \\
\hline ThO2 & 0 & - & - & - & - & - & - & - & - & - & - & - \\
\hline $\mathrm{NiO}$ & 0,007 & - & - & - & - & - & - & - & - & - & - & - \\
\hline V2O5 & 0,084 & 0,008 & 0 & 0,014 & 0,047 & 0 & 0,021 & 0,047 & 0,039 & 0,058 & 0,005 & 0 \\
\hline $\mathrm{Nb} 2 \mathrm{O} 5$ & 0,042 & & & & & & & & & & & \\
\hline $\mathrm{La} 2 \mathrm{O} 3$ & 0,008 & 0 & 0,016 & 0,05 & 0,02 & 0,002 & 0 & 0,031 & 0,026 & 0,019 & 0,014 & 0 \\
\hline $\mathrm{Ce} 2 \mathrm{O} 3$ & 0 & 0 & 0,081 & 0,14 & 0,133 & 0 & 0 & 0,06 & 0 & 0 & 0 & 0,08 \\
\hline Pr2O3 & 0 & 0 & 0,026 & 0,026 & 0,063 & 0 & 0,006 & 0 & 0 & 0 & 0,024 & 0,039 \\
\hline $\mathrm{Nd} 2 \mathrm{O} 3$ & 0,1 & 0,001 & 0 & 0,126 & 0 & 0 & 0 & 0,002 & 0,087 & 0 & 0,004 & 0,096 \\
\hline $\mathrm{Sm} 2 \mathrm{O} 3$ & 0 & 0 & 0 & 0 & 0 & 0 & 0 & 0 & 0 & 0 & 0 & 0 \\
\hline Eu2O3 & 0,03 & 0 & 0 & 0,011 & 0,015 & 0 & 0,017 & 0,008 & 0,031 & 0 & 0 & 0 \\
\hline $\mathrm{Gd} 2 \mathrm{O} 3$ & 0 & 0 & 0 & 0 & 0 & 0,017 & 0 & 0 & 0 & 0 & 0 & 0 \\
\hline Tb2O3 & 0 & 0,121 & 0,002 & 0,206 & 0 & 0 & 0 & 0 & 0,157 & 0 & 0,09 & 0,023 \\
\hline Dy2O3 & 0 & 0 & 0,025 & 0,033 & 0,033 & 0,03 & 0 & 0,007 & 0 & 0,059 & 0,082 & 0 \\
\hline $\mathrm{Ho} 2 \mathrm{O} 3$ & 0 & 0 & 0 & 0 & 0 & 0 & 0 & 0 & 0 & 0 & 0 & 0 \\
\hline $\mathrm{Yb} 2 \mathrm{O} 3$ & 0 & 0,032 & 0,012 & 0,008 & 0,009 & 0 & 0,04 & 0 & 0 & 0,031 & 0 & 0 \\
\hline Lu2O3 & 0,088 & 0 & 0,023 & 0 & 0,007 & 0 & 0,042 & 0 & 0,013 & 0,02 & 0 & 0,066 \\
\hline $\mathrm{F}$ & 5,049 & 2,189 & 3,618 & 5,529 & 2,818 & 2,811 & 3,3 & 4,19 & 5,132 & 2,349 & 4,901 & 2,846 \\
\hline $\mathrm{Cl}$ & 0,006 & 0 & 0,01 & 0,013 & 0,005 & 0,018 & 0,028 & 0 & 0,006 & 0,012 & 0,012 & 0,001 \\
\hline $\mathrm{H}^{2 \mathrm{O}}$ & 0,62 & 1,27 & 0,95 & 0,51 & 1,14 & 1,14 & 1,02 & 0,82 & 0,56 & 1,23 & 0,65 & 1,12 \\
\hline Total & 99,78 & 100,15 & 99,74 & 99,52 & 100,44 & 100,73 & 100,28 & 99,88 & 98,05 & 99,53 & 99,71 & 99,54 \\
\hline \multicolumn{13}{|c|}{ FÓRMULA CALCULADA COM BASE EM 25 OXIGÊNIOS } \\
\hline $\mathrm{P}$ & 5,986 & 5,935 & 6,033 & 6,066 & 5,984 & 6,018 & 5,992 & 6,036 & 5,944 & 5,977 & 6,036 & 5,988 \\
\hline Si & 0,000 & 0,000 & 0,000 & 0,002 & 0,000 & 0,002 & 0,000 & 0,000 & 0,000 & 0,000 & 0,000 & 0,000 \\
\hline $\mathrm{Ti}$ & 0,000 & 0,001 & 0,000 & 0,000 & 0,000 & 0,000 & 0,000 & 0,002 & 0,000 & 0,000 & 0,000 & 0,000 \\
\hline $\mathrm{Al}$ & 0,000 & 0,000 & 0,000 & 0,000 & 0,000 & 0,000 & 0,000 & 0,000 & 0,000 & 0,000 & 0,001 & 0,001 \\
\hline $\mathrm{Fe}$ & 0,034 & 0,043 & 0,042 & 0,019 & 0,046 & 0,009 & 0,000 & 0,094 & 0,089 & 0,110 & 0,057 & 0,089 \\
\hline
\end{tabular}




\begin{tabular}{|c|c|c|c|c|c|c|c|c|c|c|c|c|}
\hline $\mathrm{Mn}$ & 0,337 & 0,421 & 0,447 & 0,431 & 0,428 & 0,570 & 0,398 & 0,327 & 0,374 & 0,340 & 0,260 & 0,363 \\
\hline $\mathrm{Mg}$ & 0,002 & 0,006 & 0,000 & 0,001 & 0,003 & 0,000 & 0,001 & 0,000 & 0,002 & 0,000 & 0,005 & 0,000 \\
\hline $\mathrm{Ca}$ & 9,655 & 9,583 & 9,413 & 9,351 & 9,549 & 9,367 & 9,602 & 9,471 & 9,665 & 9,595 & 9,575 & 9,562 \\
\hline $\mathrm{Na}$ & 0,004 & 0,093 & 0,028 & 0,049 & 0,002 & 0,002 & 0,015 & 0,000 & 0,000 & 0,004 & 0,000 & 0,000 \\
\hline $\mathrm{K}$ & 0,000 & 0,099 & 0,003 & 0,000 & 0,010 & 0,003 & 0,009 & 0,000 & 0,004 & 0,000 & 0,000 & 0,000 \\
\hline $\mathrm{Sr}$ & 0,005 & 0,007 & 0,000 & 0,005 & 0,004 & 0,003 & 0,002 & 0,012 & 0,005 & 0,005 & 0,008 & 0,010 \\
\hline $\mathrm{Ba}$ & 0,000 & 0,006 & 0,000 & 0,000 & 0,003 & 0,001 & 0,005 & 0,000 & 0,002 & 0,007 & 0,000 & 0,003 \\
\hline Th & 0,000 & 0,000 & 0,000 & 0,000 & 0,000 & 0,000 & 0,000 & 0,000 & 0,000 & 0,000 & 0,000 & 0,000 \\
\hline $\mathrm{Ni}$ & 0,0010 & 0,0000 & 0,0000 & 0,0000 & 0,0000 & 0,0000 & 0,0000 & 0,0000 & 0,0000 & 0,0000 & 0,0000 & 0,0000 \\
\hline $\mathrm{V}$ & 0,0094 & 0,0009 & 0,0000 & 0,0014 & 0,0049 & 0,0000 & 0,0022 & 0,0048 & 0,0040 & 0,0062 & 0,0005 & 0,0000 \\
\hline $\mathrm{Nb}$ & 0,0032 & 0,0000 & 0,0000 & 0,0000 & 0,0000 & 0,0000 & 0,0000 & 0,0000 & 0,0000 & 0,0000 & 0,0000 & 0,0000 \\
\hline $\mathrm{La}$ & 0,0005 & 0,0000 & 0,0009 & 0,0028 & 0,0012 & 0,0001 & 0,0000 & 0,0018 & 0,0015 & 0,0011 & 0,0008 & 0,0000 \\
\hline $\mathrm{Ce}$ & 0,0000 & 0,0000 & 0,0046 & 0,0077 & 0,0077 & 0,0000 & 0,0000 & 0,0034 & 0,0000 & 0,0000 & 0,0000 & 0,0047 \\
\hline $\operatorname{Pr}$ & 0,0000 & 0,0000 & 0,0015 & 0,0014 & 0,0036 & 0,0000 & 0,0003 & 0,0000 & 0,0000 & 0,0000 & 0,0013 & 0,0023 \\
\hline $\mathrm{Nd}$ & 0,0060 & 0,0001 & 0,0000 & 0,0068 & 0,0000 & 0,0000 & 0,0000 & 0,0001 & 0,0048 & 0,0000 & 0,0002 & 0,0055 \\
\hline Sm & 0,0000 & 0,0000 & 0,0000 & 0,0000 & 0,0000 & 0,0000 & 0,0000 & 0,0000 & 0,0000 & 0,0000 & 0,0000 & 0,0000 \\
\hline $\mathrm{Eu}$ & 0,0017 & 0,0000 & 0,0000 & 0,0006 & 0,0008 & 0,0000 & 0,0009 & 0,0004 & 0,0016 & 0,0000 & 0,0000 & 0,0000 \\
\hline $\mathrm{Gd}$ & 0,0000 & 0,0000 & 0,0000 & 0,0000 & 0,0000 & 0,0009 & 0,0000 & 0,0000 & 0,0000 & 0,0000 & 0,0000 & 0,0000 \\
\hline $\mathrm{Tb}$ & 0,0000 & 0,0027 & 0,0000 & 0,0011 & 0,0052 & 0,0000 & 0,0000 & 0,0000 & 0,0000 & 0,0000 & 0,0000 & 0,0020 \\
\hline Dy & 0,0000 & 0,0063 & 0,0001 & 0,0100 & 0,0000 & 0,0000 & 0,0000 & 0,0000 & 0,0079 & 0,0000 & 0,0044 & 0,0012 \\
\hline Ho & 0,0000 & 0,0000 & 0,0012 & 0,0016 & 0,0017 & 0,0015 & 0,0000 & 0,0003 & 0,0000 & 0,0030 & 0,0040 & 0,0000 \\
\hline $\mathrm{Yb}$ & 0,0000 & 0,0016 & 0,0006 & 0,0004 & 0,0004 & 0,0000 & 0,0019 & 0,0000 & 0,0000 & 0,0015 & 0,0000 & 0,0000 \\
\hline $\mathrm{Lu}$ & 0,0045 & 0,0000 & 0,0011 & 0,0000 & 0,0003 & 0,0000 & 0,0020 & 0,0000 & 0,0006 & 0,0010 & 0,0000 & 0,0032 \\
\hline $\mathrm{F}$ & 1,303 & 0,566 & 0,932 & 1,425 & 0,723 & 0,719 & 0,847 & 1,078 & 1,354 & 0,609 & 1,261 & 0,737 \\
\hline $\mathrm{Cl}$ & 0,002 & 0,000 & 0,003 & 0,004 & 0,001 & 0,005 & 0,008 & 0,000 & 0,002 & 0,003 & 0,003 & 0,000 \\
\hline $\mathrm{H}_{2} \mathrm{O}^{*}$ & 0,695 & 1,434 & 1,065 & 0,571 & 1,275 & 1,276 & 1,145 & 0,922 & 0,644 & 1,388 & 0,736 & 1,263 \\
\hline Total & 18,023 & 18,193 & 17,966 & 17,924 & 18,029 & 17,974 & 18,024 & 17,943 & 18,085 & 18,037 & 17,943 & 18,016 \\
\hline Sitio P & 5,986 & 5,935 & 6,033 & 6,068 & 5,984 & 6,019 & 5,992 & 6,036 & 5,944 & 5,977 & 6,036 & 5,988 \\
\hline $\begin{array}{l}\text { Sitio } \mathrm{Ca} \\
\end{array}$ & 10,037 & 10,258 & 9,932 & 9,856 & 10,045 & 9,955 & 10,032 & 9,907 & 10,141 & 10,060 & 9,907 & 10,028 \\
\hline $\begin{array}{c}\text { Sitio } \\
(\mathrm{F}, \mathrm{Cl}, \mathrm{OH})\end{array}$ & 2,000 & 2,000 & 2,000 & 2,000 & 2,000 & 2,000 & 2,000 & 2,000 & 2,000 & 2,000 & 2,000 & 2,000 \\
\hline
\end{tabular}

Continuação. 